RENATA PEREIRA

\title{
Flauta doce e a Arte e Preludiar: Tradução Comentada do tratado L'Art de Preluder (1719) de Jacques Martin Hotteterre - Le Romain
}

Dissertação apresentada ao Programa de Pós-Graduação em Música, Área de Concentração Processos de Criação Musical, Linha de Pesquisa Técnicas Composicionais e Questões Interpretativas, da Escola de Comunicações e Artes da Universidade de São Paulo, como exigência parcial para obtenção do Título de Mestre em Música, sob a orientação do Prof. Dr. Gilmar Roberto Jardim. 
RENATA PEREIRA

\section{Flauta doce e a Arte e Preludiar: Tradução Comentada do tratado L'Art de Preluder (1719) de Jacques Martin Hotteterre - Le Romain}

Dissertação apresentada ao Programa de Pós-Graduação em Música, Área de Concentração Processos de Criação Musical, Linha de Pesquisa Técnicas Composicionais e Questões Interpretativas, da Escola de Comunicações e Artes da Universidade de São Paulo, como exigência parcial para obtenção do Título de Mestre em Música, sob a orientação do Prof. Dr. Gilmar Roberto Jardim.

São Paulo

2009 


\section{FOLHA DE APROVAÇÃO}

Renata Pereira

Flauta doce e a Arte e Preludiar: Tradução Comentada do tratado L'Art de Preluder (1719) de Jacques Martin Hotteterre - Le Romain

Dissertação apresentada ao Programa de Pós-Graduação em Música da Escola de Comunicações e Artes da Universidade de São Paulo, como exigência parcial para obtenção do Título de Mestre em Música.

Área de concentração: Processos de Criação Musical

Aprovado em:

Banca Examinadora

Prof. Dr.

Instituição: Assinatura:

Prof. Dr.

Instituição: Assinatura:

Prof. Dr.

Instituição: Assinatura: 
"o exórdio é o começo do discurso, ou seja, o que na poesia é o prólogo e na música de flautas, o prelúdio: todos estes são, efetivamente, começos e preparação do caminho para o que segue depois".

ARISTÓTELES, Retórica III, 14 


\section{AGRADECIMENTOS}

Expresso minha gratidão a todos que colaboraram, direta ou indiretamente, para a realização deste trabalho.

À FAPESP: Fundação de Amparo à Pesquisa do Estado de São Paulo, pela concessão de subsídio para a realização deste trabalho.

Ao Prof. Dr. Gilmar Roberto Jardim (Gil), por todo o apoio e orientação durante o trabalho.

À Prof ${ }^{\mathrm{a}}$. Dr. ${ }^{\mathrm{a}}$ Mônica Isabel Lucas, pelas leituras atenciosas durante todo o mestrado.

Ao Prof. Ricardo Kanji, pelas ideias, sugestões e compreensão nestes dois anos de trabalho em conjunto.

À Prof ${ }^{a}$. Dr. ${ }^{a}$ Leila Aguiar, pela leitura minuciosa da qualificação deste trabalho e por todas as sugestões e críticas.

Às amigas Cristiane e Luciana, do Departamento de Música da ECA-USP, por toda a dedicação e carinho em momentos burocráticos.

Ao amigo Carlos Feller, por ajudar prontamente.

Aos amigos e flautistas do QUINTA ESSENTIA quarteto, pelas oportunidades de dividir as reflexões e pesquisas.

A todos os amigos e alunos da Scuola Italiana Eugenio Montale, pela compreensão e oportunidade de poder dividir cada nova descoberta.

Aos meus queridos pais, Anita e Evaldo, pelo incentivo e apoio sempre.

Às minhas irmãs Fernanda e Flávia, pelas ideias, leituras, incentivo e exemplo.

Ao amigo Bruno Maroneze, pelo carinho e atenção com que fez a revisão desta dissertação.

Ao Gustavo, por me ouvir, por compartilhar leituras, pelas críticas e sugestões carinhosas; pela compreensão, incentivo, dedicação e amor. 


\section{RESUMO}

Esta dissertação consiste na tradução comentada do tratado L'Art de Preluder de Jacques Martin Hotteterre - Le Romain (1674-1763), publicado em Paris em 1719. Este trabalho teve como objetivo ampliar a literatura em língua portuguesa para a flauta doce, tornando-o acessível aos estudantes de música e principalmente aos instrumentistas de sopro que se preocupam com uma performance historicamente orientada. Para tanto, foram estudados termos importantes que circundam a Arte de Preludiar de Hotteterre de acordo com as fontes primárias, como os dicionários setecentistas de Furetière e Brossard, e fontes secundárias, como o dicionário de Benoit. A pesquisa de termos indicou a dimensão retórica de diversos conceitos utilizados no tratado, tais como arte, engenho, capricho, princípios, método etc. Além da pesquisa de elementos gerais pertencentes ao estilo barroco francês, uma biografia do instrumentista e compositor, a relação de suas obras e, ainda, o resgate do significado setecentista do gênero musical "prelúdio", são partes integrantes deste trabalho. Este trabalho mostra que a técnica de improvisação apresentada por Hotteterre é baseada em práticas francesas e italianas. Esse fato permitiu conhecer uma nova dimensão da influência italiana na música francesa do início do Setecentos.

Palavras-chave: Jacques Martin Hotteterre; L'Art de Preluder; prelúdio; música barroca; estilo francês. 


\section{ABSTRACT}

This work is a commented translation of the treaty L'Art de Preluder by Jacques Martin Hotteterre - Le Romain (1674-1783), published in Paris in 1719. The purpose of this work is to extend the recorder references in Portuguese language, making it accessible to music students and wind musicians that care about historical performance. For that, all-important terms that were used in the treaty were studied with the primary sources, like Brossard and Furetière's eighteenth dictionaries, and with secondary sources, like the Benoit Dictionary. This research of terms points to a rhetorical dimension of various terms used in the treated, like art, wit (ingenium), caprice, principles, method, etc. Beyond the research of French style's general elements, a musician composer's biography, his works' list, and so the eighteenth means of the "prelude" musical genre, are part of this work. The research points that Hotteterre's improvisation technique is based in Italian and French practices. This fact allowed to know a new dimension of the Italian influence in the French early eighteenth century music.

Keywords: Jacques Martin Hotteterre; L'Art de Preluder; prelude; baroque music; French style. 


\section{LISTA DE FIGURAS}

\section{Capítulo 1 Elementos Gerais}

Figura 1.1.

Advertência do primeiro livro de peças para flauta traversa (p. 30).

Figura 1.2.

Imagem extraída da advertência do primeiro livro de peças para flauta traversa (p. 31).

Figura 1.3.

Exemplo de articulação extraído do Princípios da flauta traversa (p. 39).

\section{Capítulo 3 Elementos Fundamentais para a compreensão do tratado L'Art de Preluder}

Figura 3.1.

RIPA, Cesare. Emblema 'capriccio' (Iconologia) (p. 60).

Figura 3.2.

CALLOT, Jacques. Le berger jouant de la flûte. O pastor toca a flauta. (Capricci) 1621/1622 (p. 62). 


\section{SUMÁRIO}

Seção

Página

Introdução 1

Capítulo 1 Elementos Gerais $\quad 5$

1.1. Le Style Grand e Le Style Beau

1.2. O Stilo Choraico e as Pièces de Caractères $\quad 12$

$\begin{array}{ll}\text { Allemande } & 15 \\ \text { Bourree } & 15\end{array}$

Bourrée 16

$\begin{array}{ll}\text { Branle } & 16\end{array}$

$\begin{array}{ll}\text { Canarie } & 17\end{array}$

$\begin{array}{ll}\text { Chaconne } & 17\end{array}$

$\begin{array}{ll}\text { Cotillon } & 18\end{array}$

$\begin{array}{ll}\text { Courante } & 19\end{array}$

Entrée 20

Forlane 20

Gavotte 21

Gigue 22

Loure $\quad 22$

Marche 23

Menuet 23

Passacaille $\quad 24$

Passepied 25

Rigaudon 26

Sarabande 26

1.3. Agréments e Ornements 27

1.4. Pointer $\quad 35$

Capítulo 2 Jacques Martin Hotteterre - Le Romain Flûte de la Chambre du Roy 41 Capítulo 3 Elementos Fundamentais para a compreensão do tratado L'Art de Preluder

3.1. Relação Retórica e Música: Musica practica

3.2. A Arte de Preludiar de Jacques Martin Hotteterre 56

Arte $\quad 56$

$\begin{array}{ll}\text { Prelúdio } & 57\end{array}$

$\begin{array}{ll}\text { Capricho } & 60\end{array}$

Canevas e Traits $\quad 64$

Modo 68

Capítulo 4 a Arte de Preludiar: Tradução comentada do tratado L'Art de Preluder

(1719) Jacques Martin Hotteterre - Le Romain $\quad 83$

$\begin{array}{ll}\text { Cópia do Privilégio } & 87\end{array}$

Prefácio $\quad 89$

Índice $\quad 93$

Primeiro Capítulo $\quad 95$

Do conhecimento dos graus da oitava, e das cordas por onde se deve começar e \begin{tabular}{ll} 
terminar o prelúdio. & 95 \\
\hline
\end{tabular}

$\begin{array}{ll}\text { Segundo Capítulo } & 97\end{array}$

Elementos do Prelúdio com algumas variações no modo de G ré sol. $\quad 97$

$\begin{array}{ll}\text { Terceiro Capítulo } & \mathbf{1 0 5}\end{array}$

Prelúdios sobre todos os tons em diferentes movimentos e em diferentes caracteres

para a flauta traversa, flauta doce e o oboé, etc. 
Quarto Capítulo

Contendo vários traits sobre todos os tons.

Quinto Capítulo

Prelúdios para flauta doce $\quad 129$

Sexto Capítulo

$\begin{array}{ll}\text { Traits para a flauta doce } & 141\end{array}$

Sétimo Capítulo

Da nota sensível e das regras de modulação que se deve observar no prelúdio.

\section{Oitavo Capítulo}

Explicação sobre as cadências, e sobre a distribuição que se deve fazer nos modos

maior e menor.

Nono Capítulo

Método para conhecer ao início de uma peça em que tom ela está, com uma

explicação a respeito da terça menor e da terça maior.

\section{Décimo Capítulo}

Das diferentes espécies de compassos, com explicações sobre as colcheias, etc.. 177

Compasso de 4 tempos lentos

Compasso de $\mathrm{C}$

Compasso de 2 tempos simples

Compasso Triplo maior, ou Triplo duplo 181

Compasso Triplo simples

$\begin{array}{lr}\text { Compasso de 3/8 chamado Triplo Menor } & 185\end{array}$

$\begin{array}{lr}\text { Compasso 9/8 } & 185\end{array}$

$\begin{array}{lr}\text { Compasso 6/4 } & 187\end{array}$

$\begin{array}{lr}\text { Compasso 6/8 } & 189\end{array}$

$\begin{array}{lr}\text { Compasso } 12 / 8 & 189\end{array}$

$\begin{array}{lr}\text { Compasso } 2 / 4 & 189\end{array}$

$\begin{array}{lr}\text { Prelúdios } & 195\end{array}$

$\begin{array}{ll}\text { Com cadências sobre todos os graus da oitava } & 195\end{array}$

Conclusão

Bibliografia

Fontes Primárias

Fontes Secundárias

Encarte de CD's

Tabela de digitação dos Battements 



\section{INTRODUÇÃO}

Esta pesquisa teve suas origens na busca pela literatura para flauta doce, levando à necessidade de se estudar e produzir materiais em língua portuguesa. No Brasil, existe um grande mito em torno da interpretação da música barroca francesa para flauta doce, sinônimo de grande dificuldade técnica e, por consequência, um repertório que normalmente não é escolhido pelos flautistas iniciantes no estudo da performance historicamente orientada. No estudo desse instrumento, isso geralmente acontece quando nos deparamos com a obra de Jacques Martin Hotteterre - Le Romain, um compositor extremamente conhecido dos flautistas e desconhecido dos outros músicos.

O objeto de estudo deste trabalho, o tratado L'Art de Preluder, a sétima obra de Jacques Martin Hotteterre - Le Romain, nem sempre é utilizado de acordo com a função idealizada pelo autor. Flautistas utilizam-se do tratado como um manual de repertório, ou até mesmo para obter um contato maior com o estilo francês da música instrumental setecentista. Já musicólogos e estudiosos da interpretação da música barroca servem-se do décimo primeiro capítulo rumo ao entendimento da problemática que circunda as questões rítmicas do barroco.

Pensando em aproximar o L'Art de Preluder dos instrumentistas brasileiros é que este trabalho apresenta a tradução da Arte de Preludiar de Hotteterre. No entanto, mesmo que este se encontre em nossa língua materna, uma pesquisa acerca da terminologia utilizada por Hotteterre foi indispensável para a apresentação de elementos que possibilitarão um melhor aproveitamento dessa fonte de informações da prática do gênero prelúdio e do estilo francês da música instrumental.

No primeiro capítulo são apresentados os elementos gerais que circundam a interpretação da música francesa setecentista. O estilo francês e a discussão sobre o estilo italiano; a relação entre a dança e a música instrumental, como, por exemplo, as pièces de caractères; os agréments; e principalmente o pointer, ou a desigualdade de notas igualmente escritas [inégalité]; são informações que ajudarão na compreensão da música instrumental francesa setecentista e do pensamento de Hotteterre em sua obra.

O segundo capítulo nos aproxima da vida e de toda a produção musical de Jacques Martin Hotteterre, o pedagogo, compositor e instrumentista emérito 
responsável pela divulgação da flauta traversa na França e pelo cuidado em cultivar e proporcionar a prática da flauta doce em todas as suas obras musicais e didáticas ${ }^{1}$.

O terceiro capítulo apresenta os elementos fundamentais para a compreensão do L'Art de Preluder. Elementos como a relação entre a retórica e a música e o seu desenvolvimento na França e, por consequência, termos como arte, prelúdio, capricho, engenho, modo, caneva, trait, mouvement e caractère, tiveram que ser esclarecidos de acordo com o significado setecentista. Para isso, fontes primárias como os dicionários de Furetière (1690) e Brossard (1708) foram fundamentais nessa pesquisa.

De grande importância para os estudantes de flauta doce no Brasil e também para outros instrumentistas de sopro, o quarto capítulo é a tradução para a língua portuguesa do tratado L'Art de Preluder sur la flûte traversière, sur la flûte à bec, sur le hautbois, et autres instruments de dessus avec des préludes tous faits sur tous les tons dans différents mouvements et différents caractères, accompagnés de leurs agréments et de plusieurs difficultés propres à exercer et à fortifier, ensemble des principes de modulation et de transposition; en outre une dissertation instructive sur toutes les différentes espèces de mesures, etc., "A Arte de Preludiar para a flauta traversa, para a flauta doce, para o oboé, e outros instrumentos de dessus; com prelúdios compostos em todos os tons, em diferentes movimentos e diferentes caracteres; acompanhados de seus ornamentos e de várias dificuldades apropriadas para praticar e para reforçar. Conjunto dos Princípios de modulação e de transposição; além disso, uma dissertação instrutiva sobre todas as diferentes espécies de compasso, etc." de Jacques Martin Hotteterre - Le Romain.

A edição original foi publicada em 1719, e a tradução contida nesta dissertação foi baseada em três edições fac-similares. A primeira, publicada pela Editions Aug. Zurfluh em Paris, é de 1966. A segunda foi publicada em 1978, em Genebra, pela Minkoff. A terceira, publicada pela S.P.E.S - Studio per Edizioni Scelte em Florença, é de 1999.

\footnotetext{
1 No tratado de flauta doce, parte integrante do Principes de la flûte traversière, Hotteterre explica que ele resolveu inserir uma parte dedicada à flauta doce, pois esta tem seus méritos e partidários tanto quanto a flauta traversa, instrumento este que ele afirma ser um dos mais agradáveis e que está se tornando comum na França, em 1707, ano da publicação do Principes. Cf. HOTTETERRE, J. M. Principes de la Flûte Traversière. Paris: Ballard, 1707. Edição fac-similar. Genebra: Minkoff, 1973. p. 3, 39. No L'Art de Preluder ele explica sobre as adaptações que se pode fazer do repertório de flauta traversa para a flauta doce, mais uma vez uma preocupação evidente de Hotteterre com o uso da flauta doce na França. Cf. capítulo IV deste trabalho.
} 
Devido ao fato de o texto de Hotteterre ser de escrita diferente da contemporânea, sobretudo no tocante à pontuação, foi necessário, para o trabalho de tradução, o emprego da pontuação segundo as regras da língua portuguesa, bem como a escolha pela divisão em parágrafos, a fim de facilitar a compreensão do texto.

O conteúdo principal desse trabalho didático de Hotteterre é, com certeza, a composição extemporânea prelúdio, que não é própria do tempo ou do momento em que ocorre. No entanto, nos capítulos seguintes, ele nos dá diversas informações indispensáveis para a prática da música instrumental francesa setecentista e que, como afirma Hotteterre, devem ser aplicadas nos exemplos de prelúdio contidos no L'Art de Preluder, pois são apropriados para colocar todos esses princípios em prática².

A coerência terminológica tornou-se a preocupação fundamental da execução deste trabalho. Muitos termos utilizados por Hotteterre teriam dificultado a compreensão do trabalho se não tivessem sido consultados em fontes primárias.

Todo o trabalho de tradução e pesquisa foi realizado em fontes primárias e secundárias; e em se tratando de música francesa, dicionários e livros franceses, literatura italiana e trabalhos atuais em língua inglesa foram consultados. Por esse motivo também, essa pesquisa é de extrema importância para o cenário musical brasileiro, pelo acesso em língua portuguesa não somente do texto integral do L'Art de Preluder, mas também de exemplos, reflexões e conclusões oriundas de outras pesquisas sobre Hotteterre e sobre a música barroca francesa.

O presente trabalho tem como objetivo proporcionar o acesso às informações em língua portuguesa do tratado setecentista de Hotteterre, desmitificando assim a sua utilização atribuída por flautistas e a prática da música barroca francesa no Brasil. Além dos princípios da Arte de Preludiar, Hotteterre nos proporciona elementos fundamentais para a prática da interpretação da música instrumental francesa setecentista.

\footnotetext{
2 "Les Préludes que j'ai donnés dans ce Livre conviendront fort pour mettre ces Principes en pratique". Cf. HOTTETERRE, J. M. Op. cit., p. 51.
} 



\section{CAPÍTULO 1}

\section{ELEMENTOS GERAIS}

\subsection{Le Style Grand e Le Style Beau}

Nos diferentes centros culturais dos séculos XVII e XVIII, a presença de estilos distintos na música era algo tão importante que refletia, de certa forma, a rivalidade das nações. Essas comparações estilísticas musicais existentes nos séculos XVII e XVIII, registradas em tratados - como o Parallèle des Italiens et des Français en ce qui regarde la musique et les opéras, do Abbé François Raguenet, publicado em 1702, e o Comparaison de la musique italienne et de la musique française, de Jean Laurent le Cerf de la Viéville, publicado em 1705 - salientavam ainda mais as características e as propriedades de cada estilo.

Para uma compreensão mais objetiva acerca dessa qualidade fundamental da música do período barroco, o estilo, passemos à definição do termo e às considerações sobre os estilos italiano e francês. Essas informações serão fundamentais para compreendermos a obra de Jacques Martin Hotteterre - Le Romain.

Sébastien de Brossard, em seu Dictionnaire de Musique (1708), apresenta uma extensa definição sobre estilo em música, citada aqui, em parte, como: 
[...] a maneira que cada indivíduo tem para compor, executar, ou ensinar, e tudo isto é muito diferente segundo o engenho dos Autores, do País, e da Nação; como também segundo as matérias, os lugares, os tempos, os sujeitos, as expressões, etc. [...]

Blainville, em seu L'Esprit de L'Art Musical ou Réflexions sur la Musique, de 1754, salienta que o "estilo consiste no caráter, no tour de chant [movimento da melodia], e na maneira de acrescentar o baixo e as outras partes" ${ }^{\prime 3}$. Embora para ele pareça difícil definir esse termo, ressalta que as diferenças aparecem no caráter, no movimento e na escrita das vozes.

Através das definições de Brossard e Blainville podemos inferir que estilo é algo referente ao caráter do autor e da nação, pressupondo um decoro de lugar e de tempo, referido por Brossard. Essa definição se completa com o pensamento de Blainville, cuja explicação afirma que tudo isso se reflete na escrita musical em si.

Brossard continua a sua definição de estilo falando de dois estilos nacionais, que parecem ser, portanto, dois estilos que ele compreendia como principais: o italiano e o francês, cada um com as suas características. "O estilo das composições italianas é picante, florido, expressivo; o [estilo] das composições francesas é natural, fluente, sensível [delicado], etc" ${ }^{\prime 4}$.

Brossard está se referindo a uma divisão de estilos que era amplamente discutida em sua época. A discussão sobre os estilos italiano e francês no período barroco surge no século XVIII, mediante uma erupção de publicações sobre o assunto, como o Parallèle des Italiens et des Français en ce qui regarde la musique et les opéras e o Comparaison de la musique italienne et de la musique française, obras já citadas.

Blainville também compara os estilos italiano e francês. Ele diz que

[...] Os italianos são também diferentes de nós [franceses] neste gênero [estilo], como também o são no caráter e na língua. [...] o gênero de uma Música nasce particularmente do caráter e da língua de uma Nação. A nossa língua [francesa] é sábia [ponderada] e ingênua. Por um lado, ela não tem muito brilho, por outro, é fluida e fácil; ela se presta

\footnotetext{
3 "Style qui consiste dans le caractère, le tour de chant, e dans la manière d'ajouter la basse, e les autres parties." In: BLAINVILLE, C. H. Op.cit., p. 43.

4 "[...] En Musique, on le dit de la manière que chaque particulier a de composer, ou d'exécuter, ou d'enseigner, e tout cela est fort diffèrent selon le génie des Auteurs, du Pays e de la Nation; comme aussi selon le matières, les lieux, les temps, les sujets, les expressions, etc. [...] Le style des compositions Italiennes est piquant, fleuri, expressif; celui des compositions Françaises, est naturel, coulant, tendre, etc. [...]" In: BROSSARD, Sébastien de. Dictionnaire de Musique. Amsterdam, 1708, $3^{\mathrm{a}}$ ed. Paris: Minkoff, 1992. p. 135.
} 
pouco às imagens, mas tem a vantagem de ser naturalmente apropriada às características nobres, às expressões de sentimento, e às cenas galantes, às festas heróicas e de divindades, às festas infernais, às festas dos bosques e festas pastorais; enfim a tudo o que se relaciona às nossas sensações ${ }^{5}$.

Nikolaus Harnoncourt, em seu livro O Discurso dos Sons ${ }^{6}$, diz que as raízes da música barroca se encontram na Itália, e que a música francesa dessa época surge quase como uma reação à erupção musical dos italianos.

A busca de Luís XIV (o Rei Sol) pela hegemonia de seu reinado em todas as áreas incentivou a criação de uma produção musical genuinamente francesa. Em 1666, cinco anos após ter naturalizado o italiano Lully - que passaria a ser o responsável pela música da corte francesa -, Luís XIV demite todos os músicos italianos estabelecidos na França, deixando claro o seu desejo de manter uma produção artística puramente francesa ${ }^{7}$.

Essa postura foi decisiva para o crescimento dos debates sobre estilos e para a produção musical, determinando a conduta dos músicos franceses. No entanto, mesmo sendo fiéis ao estilo pregado pelo rei, muitos compositores franceses publicavam músicas sob um pseudônimo italiano, quando estas não estavam escritas no gosto francês ${ }^{8}$.

Com a morte de Luís XIV, em $1715^{9}$, o estilo italiano tornou a ser cultivado na França. A esse respeito, House afirma que Couperin admitiria, 20 anos mais tarde, que havia produzido composições na década de 1690 sob um pseudônimo italiano, e que o seu desejo era extrair o melhor dos estilos francês e italiano para criar o Les Goûts Réunis (os gostos reunidos).

\footnotetext{
5 “[...] Les Italiens sont aussi différents de nous en ce genre, qu'ils le sont de caractère e de langage. [...] le genre d'une Musique nait particulièrement du caractère e de la Langue d'une Nation. Notre Langue est sage e naïve. Si elle n'a pas beaucoup d'éclat, elle est coulante e aisée; elle se prête peu aux images, mais elle a l'avantage d'être naturellement propre aux caractères nobles, aux expressions de sentiment, e aux scènes galantes, aux fêtes hérö̈ques e de divinités, aux fêtes infernales, aux fêtes des bois e des bergeries; enfin à tout ce qui a rapport à nos sensations." In: BLAINVILLE, C. H. Op.cit., p. 43-44.

${ }^{6}$ HARNONCOURT, Nikolaus. O Discurso dos Sons: Caminhos para uma nova compreensão musical. Rio de Janeiro: Jorge Zahar Ed., 1998.

7 ISHERWOOD, 1973 apud HOUSE, Delpha LeAnn. Jacques Hotteterre 'Le Romain': A study of his life and compositional style. Chapell Hill: The University of North Carolina at Chapell Hill, 1991. p. 10.

8 Ibid., p.14.

9 Sobre a postura musical de Luís XIV e as modificações que a sua morte ocasionou, cf. BOND, A. French Baroque Style in Performance. In: A Guide to the Harpsichord. Portland, Oregon: Amadeus Press, 1997. p. 160
} 
Hotteterre, nessa mesma década de 1690, havia ido à Itália a serviço do Príncipe Francesco Maria Ruspoli. Contudo, somente após a morte de Luís XIV, com a publicação do L'Art de Préluder, é que ele assume o seu gosto pelo estilo italiano, o que é reforçado através do pseudônimo 'Le Romain' [o Romano]. ${ }^{10}$

Enquanto a música italiana era dominada pelas formas musicais como a sonata e o concerto, com seus adagios com ornamentação rica providenciada pelo intérprete, e o virtuosismo típico do barroco italiano, a música francesa concebida por Lully possuía uma forma clara e concisa e movimentos curtos, sendo sobretudo voltada para a dança. Sobre as características acima e outras, Rowland-Jones, em seu artigo The Baroque Recorder Sonata, apresenta a seguinte tabela:

\begin{tabular}{|c|c|}
\hline Estilo Francês & Estilo Italiano \\
\hline delicado, suave, [de aparência] fácil, fluido & $\begin{array}{l}\text { vivo, animado, quente [picante], [de } \\
\text { aparência] difícil }\end{array}$ \\
\hline moderado e restrito & extremos da expressão, desenfreado \\
\hline acaricia o ouvido, doçura perpétua & energia, violência, estranheza \\
\hline gosto (goût) [estilo] & paixão (gusto) [inclinação] \\
\hline $\begin{array}{l}\text { formalidade e adequação (com risco de } \\
\text { insensibilidade) }\end{array}$ & $\begin{array}{l}\text { novidade e exibição (com risco de 'cair' no } \\
\text { vazio) }\end{array}$ \\
\hline melodia natural & $\begin{array}{l}\text { supérfluos artifícios, ornamentação } \\
\text { extravagante, frequentes e severos saltos }\end{array}$ \\
\hline estabilidade e requinte & urgência, estímulo e vangloriar-se \\
\hline claridade e elegância & $\begin{array}{l}\text { chiaroscuro [contraste] dramática luz e } \\
\text { sombra }\end{array}$ \\
\hline sério, terno e paixões sustentadas & excesso de imaginação \\
\hline $\begin{array}{l}\text { principalmente baseado em danças e caráter } \\
\text { ou (gênero) de peças descritivas } \\
\text { harmonia contida e dissonâncias preparadas } \\
\text { exceto para efeitos especiais } \\
\text { mais variedade rítmica dentro do pulso } \\
\text { (desigualdade de pares de notas) [inegalité] }\end{array}$ & $\begin{array}{l}\text { mais peças acadêmicas (ex. fugas) e } \\
\text { movimentos indicando fortes afetos } \\
\text { e, por vezes dramática, surpreendente } \\
\text { discórdias; frequentes suspensões dissonantes } \\
\text { variedade rítmica em uma escala mais ampla }\end{array}$ \\
\hline $\begin{array}{l}\text { acentos marcados por ornamentação } \\
\text { (chamados accent) }\end{array}$ & $\begin{array}{l}\text { acentos marcados por arcadas ou pressão de } \\
\text { ar }\end{array}$ \\
\hline $\begin{array}{l}\text { ornamentação específica integrada à } \\
\text { composição como forma de expressão } \\
\text { indicações francesas de tempo e outras } \\
\text { orientações }\end{array}$ & $\begin{array}{l}\text { improvisação realizada pelo intérprete } \\
\text { especialmente em movimentos lentos } \\
\text { indicações italianas de tempo e 'afetos' }\end{array}$ \\
\hline timbre: flauta & timbre: violino \\
\hline $\begin{array}{l}\text { objetivo e desapaixonado é a primeira } \\
\text { abordagem, o intérprete torna-se atraído, } \\
\text { apaixonado e movido pela música, apesar de } \\
\text { sua atitude de tocar nunca exceder } \\
\text { (delicadeza) }\end{array}$ & $\begin{array}{l}\text { imediata identificação com e total imersão do } \\
\text { intérprete nos afetos da peça. Atitude de tocar } \\
\text { demonstrada }\end{array}$ \\
\hline
\end{tabular}

10 Cf. LASOCKI, David. The Recorder in print: 2004. In: American Recorder Magazine. American Recorder Society: Maio, 2006. p. 15. 
Algumas características mencionadas por Rowland-Jones em sua comparação entre os estilos italiano e francês aparecem também na distinção estabelecida por Blainville. Contudo, a definição do autor setecentista nos fornece alguns dados interessantes, não apontados por Rowland-Jones. Blainville descreve os dois estilos da seguinte maneira:

[...] A poesia italiana, viva e picante, [é] própria para as imagens, para os diversos fenômenos que ocorrem fora de nós; pelo contrário, a língua francesa, sábia, nobre e circunspecta, agrada particularmente apenas aos sentimentos das nossas paixões, às afeições, aos movimentos que se passam em nós; enfim, o estilo dos italianos é grande [style grand] [naqueles aspectos em que] é conciso e firme; e o nosso, [francês] é belo [style beau], [naqueles aspectos em que] é prolixo e conciso. Pode-se comparar o primeiro, devido à violência, à rapidez e à veemência com a qual devasta, por assim dizer, leva tudo a uma tempestade, a um raio. O nosso [estilo] é um fogo moderado que não se apaga, que se for alimentado a cada passo, e à medida que se avança, toma sempre novas forças. Um é melhor para as exagerações fortes e para as grandes paixões, para as grandes imagens, quando é necessário, por assim dizer, surpreender o ouvinte. O outro suave, e tranquilo, por uma abundância igual, é melhor, pode-se dizer, para espalhar um suave e agradável orvalhar nos espíritos [consolar, suavizar a dor ${ }^{11}$.

Blainville acreditava que o estilo em música nasce particularmente do caráter e da língua de cada nação. Aliando essa informação aos termos utilizados na sua citação, Blainville parece comparar o estilo em música ao estilo dos discursos retóricos. Para uma melhor compreensão das palavras de Blainville, ao se referir ao estilo italiano como style grand e ao estilo francês como style beau, é necessário compreender alguns termos de acordo com seu significado setecentista.

O Dictionnaire de Rhétorique de Molinié nos dá algumas definições importantes para o esclarecimento desses termos. Para ele, o estilo representa a determinação essencial e constitutiva do discurso; essa definição, aplicada ao 'discurso sem palavras', como era conhecida a música no século XVIII, o Dictionnaire universel françois et latin:

\footnotetext{
11 “[...] La Poésie Italienne, vive e piquante, est propre aux images, aux divers phénomènes qui se passent hors de nous; au contraire la Langue Françoise, sage, noble e circonspecte, ne se plaît particulièrement qu'aux sentiments de nos passions, aux affections, aux mouvements qui se passent en nous; enfin le style des Italiens est grand, en ce qu'il est concis e ferré; e le nôtre est beau, en ce qu'il est diffus e entendu. On peut comparer le premier, à cause de la violence, de la rapidité e de la véhémence avec laquelle il ravage, pour ainsi dire, e emporte tout, à une tempête, à un foudre. Pour le nôtre, c'est un feu modéré qui ne s'éteint point, qui se nourrit à chaque pas, e à mesure qu'il s'avance prend toujours de nouvelles forces. L'un vaut mieux pour les exagérations fortes e les grandes passions, les grandes images, quand il faut, pour ainsi dire, étonner l'auditeur. L'autre sauve, e tranquille, par une abondance égale est meilleur, si l'on peut dire, à répandre une douce e agréable rosée dans les esprits." In: BLAINVILLE, C. H. Op.cit., p. $45-46$.
} 
contenant la signification et la définition... des mots de l'une et de l'autre langue... la description de toutes les choses naturelles... I'explication de tout ce que renferment les sciences et les arts, de 1704, e na reedição de 1721, descreve-a como a maneira de cantar e a maneira de compor.

Para Molinié, o style grand [estilo grande]

[...] [é] associado ao estilo sublime. Pôde-se mesmo considerar que o estilo grande é o constituinte verbal do sublime. É fato que se tentarmos restringir a definição do sublime aos seus elementos formais, não saberíamos de quais poderia ser composto; na sua expressão, de outra maneira, exatamente de todas as determinações estilísticas das quais se faz referência.[...] Reencontramos então, todas as manifestações da abundância, que confere e mede à retórica seu caráter real, a sua majestade"12.

\section{Molinié descreve a abundância como}

uma característica do estilo, geralmente equivalente a uma de suas qualidades. [...] Em relação à ideia de uma hierarquia dos estilos, a abundância é um dos componentes do estilo elevado, sublime. [...] A abundância se marca, portanto, pelas diversas variações de repetição, nuances de detalhes, de paráfrases, de expolição. [...] Ela se apóia igualmente sobre todas as figuras de ornamento. [...] Enfim, se assinala como principal responsável pelas diversas fontes de variedade, que são consubstanciais à realização do grande estilo"13.

Molinié contrapõe o style beau [estilo belo, nobre] ao style bas, e afirma:

[...] O estilo baixo é oposto ao estilo sublime. A designação refere-se então às determinações da arte: nem a mais magnífica inspiração, nem, elaborações artificiais mais tensas. O estilo baixo quase designaria um suposto estilo natural, ou uma pretensão de

\footnotetext{
12 “[...] Le grand style a partie liée avec le sublime. Il est vrai que si l'on essaie de restreindre la définition du sublime à ses éléments formels, on ne voit pas de quoi il pourrait être composé, dans son expression, sinon exactement de toutes les déterminations stylistiques dont on vient de faire état. [...] On retrouve alors toutes les manifestations de l'abondance, qui confère et mesure à la rhétorique son caractère royal, sa majesté." In: MOLINIÉ, G. Dictionnaire de Rhétorique. Paris: Librairie Générale Française, 1992. p. 159-160.

13 "L'abondance est un caractère du style, généralement assimile à l'une de ses qualités. [...] Par rapport à l'idée d'une hiérarchie des styles, l'abondance est une des composantes du style élevé, sublime. [...] L'abondance se marque donc par les diverses variations de répétition, de nuancement de détails, de paraphrases, d'expolition. [...] elle s'appuie également sur toutes les figures de l'ornement. [...] Enfin, elle signale comme principale responsable des diverses sources de variété, qui sont consubstantielles à la réalisation du grand style." In: Ibid., p. 33-34
} 
naturalidade no estilo. A este respeito, de uma certa estética que não é sem qualquer referência à história ou interpretações do ideal ciceroniano ou das práticas ciceronianas, podia-se falar de um estilo belo [style beau] estilo baixo, por um aparente paradoxo na formulação. Trata-se, deste ponto de vista, de insistir sobre a apropriação de certo nível de estilo a um certo tipo de matéria tratada, nomeadamente o conjunto das paixões. Esta tendência acentua ao mesmo tempo o aspecto pessoal da relação retórica: a garantia de um bom acordo entre o locutor e o seu público pode precisamente se realizar, nas inflexões subjetivas em todo caso, seguindo uma inclinação mais comum de expressão, à condição, é claro, que ela permaneça correta e adequada. [...] Esta última acepção faz evidentemente saltar o princípio de uma hierarquia dos estilos, em todo caso dos níveis: ir-se-ia para a ideia de uma possibilidade de excelência em diferentes gêneros. A considerar a totalidade do campo retórica, e sobretudo à partir de Aristóteles, pode-se considerar que esta inflexão aparentemente paradoxal é realmente perfeitamente congruente com a verdadeira natureza da retórica ${ }^{14} \cdot[\ldots]$

Apresentando os termos utilizados por Blainville em acordo com as definições de Molinié, podemos concluir que Blainville não pretende fazer nenhum tipo de julgamento de valor ao associar o estilo italiano ao estilo grande e o estilo francês ao estilo nobre; tal conclusão se torna evidente quando o autor afirma que estes dois estilos possuem igual abundância. Ele procura apenas evidenciar as diferenças de cada estilo, como esclarecido também, no campo do discurso retórico, através das definições de Molinié.

A variedade, citada por Blainville como abundância, também é mencionada por Molinié, que a define como uma característica do estilo: constitui-se nas variações de repetições, nas nuances de detalhes, na riqueza de expressão e no ato de ornar o discurso.

Complementando a explicação de Blainville, enquanto o estilo italiano está associado a um estilo grande, rico em variedade, o estilo francês, sem elaborações artificiais, está mais próximo da busca por uma naturalidade do estilo, seguindo uma

\footnotetext{
14 " [...] L'expression style bas; on est donc situé dans la question des niveaux de style. [...] Le style bas s'oppose à style sublime. La désignation renvoie alors à déterminations de l'art, ni de la plus magnifique inspiration, ni des, élaborations artificielles les plus tendues. Le style bas désignerait presque un prétendu style naturel, ou une prétention de naturel dans le style. À cet égard, dans une certaine esthétique qui n'est pas sans renvoyer à toute une histoire des interprétations ou de l'idéal cicéronien ou des pratiques cicéroniennes, on a pu parler d'un beau style bas, par un apparent paradoxe dans la formulation. II s'agit, de ce point de vue, d'insister sur l'appropriation d'un certain niveau de style à un certain type de matière traitée, notamment l'ensemble des enjeux sentimentaux. Cette tendance accentue à la fois I'aspect personnel de la relation rhétorique: la garantie d'un bon accord entre le locuteur et son public peut justement se réaliser, dans les inflexions subjectives en tout cas, en suivant une pente plus terre à terre d'expression, à condition bien sûr qu'elle reste correcte et convenante. [...] Cette dernière acception fait évidemment sauter le principe d'une hiérarchie des styles, en tout cas des niveaux: on irait vers l'idée d'une possibilité d'excellence dans différents genres. À considérer la totalité du champ rhétorique, et surtout à partir d'Aristote, on est porte à considérer que cette inflexion apparemment paradoxale este en réalité parfaitement congruente avec la vraie nature du rhétorique. [...]" In: Ibid., p. 69-70.
} 
inclinação mais comum em relação à expressão das paixões, porém com grande excelência nos diferentes gêneros. Com isso, Blainville está em conformidade com a definição de Brossard citada no início deste capítulo, na qual o estilo francês foi retratado como natural, fluente e sensível.

A compreensão das características próprias de cada estilo é importante para uma interpretação mais adequada da música setecentista. Blainville acreditava na permanência desses estilos distintos, dizendo que "para resumir, [os estilos francês e italiano] são dois rivais que sempre existirão em razão da sua oposição"15. Toda essa discussão culminará na defesa de uma verdadeira música no início da segunda metade do século XVIII: aquela que para alguns soaria como uma unificação dos estilos, e que outros já a defendiam como sendo apenas música, sem nacionalidade ${ }^{16}$.

\subsection{O Stilo Choraico e as Pièces de Caractères}

O assunto deste capítulo é a classificação da música instrumental no pensamento francês. Segundo Brossard, a música instrumental está incluída em duas categorias: o stilo choraico, que inclui as peças de dança, comumente denominadas air à danser ou ballets, e o stilo symphoniaco, que contém as pièces de caractères.

O compositor, flautista e teórico alemão do século XVIII Johann Joachim Quantz, em seu tratado Versuch einer Anweisung die Flöte traversière zu spielen, publicado em Berlim em 1752, descreve, em diversos momentos, características e elementos importantes sobre a música instrumental francesa. Em seu XVIII capítulo, 'Como um músico e uma composição musical devem ser apreciados', ele evidencia a relação entre a dança e a música francesa, uma característica marcante do estilo francês.

[...] É incontestável que a música francesa, quando ela é considerada em toda a sua perfeição, é muito mais adequada para a dança do que qualquer outra, enquanto que a

\footnotetext{
15 “[...] Enfin, pour dire en un mot, ce sont deux rivales qui subsisteront toujours par la raison même de leur opposition. "In: BLAINVILLE, C. H. Op.cit., p. 47.

16 A discussão de estilo e a rivalidade entre as nações francesa e italiana ganha uma nova percepção de acordo com a Carta Sobre a Música Francesa (1753) de Jean-Jacques Rousseau.
} 
[música] dos italianos, por outro lado, é mais eficaz para cantar e tocar do que para dançar $[\ldots]^{17}$

Quantz afirma ainda que a música de dança francesa "[...] consiste, sobretudo, dos tipos especiais [gewiss]. Cada tipo requer o seu próprio ritmo, no entanto, uma vez que este tipo de música é muito circunscrita a sua função, não é tão arbitrária como a música italiana $[\ldots]^{\prime \prime 18}$.

O tradutor cita em nota a terminologia francesa pièces de caractères, dizendo que "esta designação é utilizada para tipos especiais de peças com características facilmente identificáveis, ou seja, as características das danças"19.

Vimos anteriormente que Brossard apresenta diversos exemplos para descrever as características de cada estilo. Ao término da sua definição ele escreve que "os italianos têm expressões para todos os [exemplos] que nós [franceses] já tínhamos dado". A seguir, ele explica diversos termos italianos, incluindo as danças no estilo que denomina choraico. Ele afirma que este consiste no estilo próprio para a dança, que se subdivide em tantas maneiras diferentes quantos forem os tipos de danças. Assim há o estilo das Sarabandas, dos Minuetos, dos Passepieds, das Gavottes, das Bourrées, dos Rigaudons, das Gailliardes, das Courantes etc ${ }^{20}$.

O stilo choraico, descrito por Brossard, também é mencionado por Quantz, quando este se refere à música de dança francesa para esclarecer que esta não é arbitrária e livre como a música dos italianos.

\footnotetext{
17 " [...] It is indisputable that the music of the French, when it is considered in all its perfection, is much better suited to the dance than any other, while that of the Italians, on the other hand, is more effective for singing and playing than for dancing [...]." In: QUANTZ, J.J. Versuch einer Anweisung die Flöte traversière zu spielen. Berlin, 1752. Trad. E. R. REILLY. On Playing the flute. Boston: Northeastern University Press, 2001. Cap. XVIII \& 67, p. 329.

18 "[...] consists for the most part of special types. Each type requires its own tempo, however, since music of this kind is very circumscribed, and is not as arbitrary as Italian music [...]" In: Ibid., Cap. XVII § 56, p. 289.

19 "The terminology here helps to explain what Quantz means in his earlier references to 'characteristic pieces' (or pièces caractères). Apparently this designation is used for special types of pieces with readily identifiable characteristic features." In: Ibid., Cap. XVII § 56, p. 289.

20 "[...] C'est le Style propre pour la danse qui se subdivise en autant de manières différentes qu'il y a de Danses. Ainsi il y a le Style des Sarabandes, des Menuets, des Passepieds, des Gavottes, des Bourrées, des Rigaudons, des Gailliardes, des Courantes, etc." In: BROSSARD, Sébastien de. Op.cit., p. 136.
} 
[...] A música francesa de dança [stilo choraico] não é tão fácil tocar quanto se imagina, a sua execução deve ser claramente distinta do estilo italiano para que seja apropriada para cada tipo de peça. A música de dança é normalmente tocada de maneira séria ${ }^{21}[\ldots]$

A segunda categoria, o estilo symphoniaco, que inclui as piéces de caractères, tem como representante principal a suíte, um conjunto de pequenas peças organizadas consecutivamente. Sobre essa relação, Philippe Beaussant comenta em seu livro Vous avez dit Baroque? que "[...] a música instrumental do período barroco é em grande parte formada - informada - pela dança. A 'suíte' é a sua forma preferida[...]"22.

Marcelle Benoit afirma, semelhantemente, que "a suíte permanece a forma primordial, quase exclusiva, da música instrumental francesa por quase três séculos"23. Essa forma teve como plano de base a sequência das danças allemande, courante, sarabande e gigue. Ainda entre a sarabande e a gigue, compositores faziam uso de danças intermediárias, como a gavotte, a bourrée e o minuet.

Para Geoffroy-Dechaume, não é somente a forma suíte que é herança deixada do encontro da dança com a música, mas sim "a dança, que possui o primeiro lugar na música instrumental francesa, teve uma influência específica sobre a notação"24.

Levando em consideração a afirmação de Geoffroy-Dechaume, é imprescindível o contato com as características das representativas danças que foram utilizadas na linguagem da música instrumental setecentista para uma melhor compreensão da música instrumental francesa.

Segundo House, essa relação entre música e dança foi inevitável; a exemplo disso a autora afirma que as características rítmicas da música francesa da década de 1680 foram influenciadas fortemente pela dança ${ }^{25}$. Essa relação influenciou a formação

\footnotetext{
21 "[...] French dance music is not as easy to play as many imagine, and that its execution must be clearly distinguished from the Italian style if it is to be suitable for each type of piece. Dance music is usually played seriously [...]" In: QUANTZ, J.J. Op.cit., Cap. XVII § 56, p. 290.

22 "[...] La musique instrumentale de l'époque baroque este $n$ grande partie formée - informée - par la danse. La 'suite' et sa forme préférée [...]." In: BEAUSSANT, Philippe. Vous Avez Dit 'Baroque'? Vendôme: Actes Sud, 1988. p.124.

23 "La suite reste la forme primordiale, quasi exclusive, de la musique instrumentale française pendant prés de trois siècles". In: BENOIT, Marcelle. Dictionnaire de la Musique en France aux XVIle et XVIIIe siècles. Paris: Fayard, 1992. p. 651.

24 "La danse, qui tient le premier rang dans la musique instrumentale française, eut une influence particulière sur la notation". In: GEOFFROY-DECHAUME, A. Les Secrets de la Musique Ancienne: Recherches sur l'interprétation. França: Fasquelle, 1983. p.48.

25 "The rhythmic characteristics of French music of the 1680 s are strongly influenced by the dance". In: HOUSE, Delpha LeAnn. Op.cit., p. 117.
} 
e a produção musical de Jacques Martin Hotteterre ${ }^{26}$. Por isso, é necessário definirmos aqui algumas danças para que as suas características venham a ser reconhecidas na obra de Hotteterre ${ }^{27}$.

São pièces de caractères citadas no L'Art de Preluder e no curso da obra do autor:

\section{a. Allemande}

Sobre a allemande, Brossard explica que é uma "symphonie grave, normalmente [escrita] em dois tempos, às vezes em quatro; ela tem duas reprises ${ }^{28}$ que são tocadas duas vezes cada uma"29. O fato de o autor deixar claro em seu dicionário que a allemande é uma symphonie e não uma dança demonstra que tratam-se de peças que possuem características de dança mas não foram feitas para serem dançadas. A definição de Benoit explica melhor a função da allemande.

Termo aplicado à várias danças de origem ou de caráter alemão entre os séculos XV e XIX. Na França, a palavra é utilizada em pelo menos três sentidos diferentes: 1 . Uma dança de 4 tempos da Renascença. 2. Parecida com esta, um movimento da suíte instrumental em uso a partir do século XVII, mas que não é dançado. 3. Uma dança de baile em casal, em moda na França a partir de 1760, logo associada à contradança ${ }^{30}$.

\footnotetext{
${ }^{26}$ HOUSE ainda afirma que não somente as características da dança na composição instrumental, mas também o contínuo debate sobre as diferenças e os relativos méritos dos estilos musicais francês e italiano, influenciaram a obra de Jacques Martin Hotteterre - Le Romain. In: Ibid., p. 82.

${ }^{27}$ As informações foram retiradas de diversas fontes primárias, como dicionários dos séculos XVII e XVIII, e de fontes secundárias, como estudos e outros dicionários sobre música.

${ }^{28} \mathrm{O}$ termo reprise, que aparece constantemente na música instrumental francesa, indica que uma parte de uma peça deve ser repetida. De Place explica que: "Na suíte, por exemplo, o termo é utilizado para descrever um retorno variado da primeira parte de um trecho [...] A petite reprise é colocada como uma pequena Coda obrigatoriamente mais ornamentada após a reprise, a menos que o compositor indique o contrário." "Dans la suite de danses, par exemple, le mot est employé pour designer un retour varié de la première partie d'un morceau [...] La petite reprise placée comme une courte coda après la reprise, et généralement plus ornementée, est toujours obligatoire, sauf indication contraire du compositeur." In: BENOIT, Marcelle. Op.cit., p. 608.

29 "Symphonie grave, ordinairement à deux temps, souvent à quatre; Elle a deux Reprises qu'on joue chacune deux fois. Ce mot vient du françois allemande." In: BROSSARD, Sébastien de. Op.cit., p. 9.

30 "Terme appliqué à plusieurs danses d'origine ou de caractère allemand entre les XVe et XIXe siècles. En France, le mot s'emploie dans au moins trois sens différents: 1 . Une danse à 4 temps de la Renaissance. 2. Apparenté à celle-ci, un mouvement de la suite instrumentale en usage au XVlle siècle, mais qui n'est pas dansé. 3. Une danse de bal en couple, à la mode en France à partir de 1760, bientôt associée à la contre-danse." In: BENOIT, Marcelle. Op.cit., p.13.
} 
A explicação de Benoit esclarece o termo symphonie de Brossard, ou seja, apesar da allemande ter sido uma dança na Renascença, quando incorporada à suíte instrumental, a partir do século XVII, manteve suas características, porém não exercia a função de dança.

\section{b. Bourrée}

Sobre a bourrée, Benoit afirma que

[...] existe também como forma instrumental independente da dança. Ela não é um dos quatro elementos fundamentais da suíte, mas na verdade muitas vezes faz parte, habitualmente entre as danças facultativas entre a sarabande e a giga $[\ldots]^{31}$.

A bourrée, uma dança popular francesa, aparece nas coleções de danças da corte no século XVI. Sua forma é binária e seu ritmo consiste em um levare de uma semínima ou de duas colcheias, muitas vezes com uma síncopa no segundo compasso. A harmonia é simples e o seu fraseado se organiza, em geral, em grupos de quatro compassos. Harnoncourt diz que, em todas as antigas descrições, ela é apresentada como muito semelhante à gavota, com um tempo mais rápido. Marcada e alegre, possui uma anacruse, que compreende uma semínima ou duas colcheias, começando com um salto vivo 32 .

\section{c. Branle}

Essa dança é simples, melódica e relativamente curta. Benoit cita que cada tipo de branle tem um perfil rítmico e fraseados que lhe são próprios. A branle simples, por exemplo, é escrita em 2 tempos e organiza-se em frases de 3 ou 6 compassos. A branle gay é a 3 tempos e, no século XVII, compreende frequentemente notas pontuadas ${ }^{33}$.

\footnotetext{
31 “[...] La bourrée existe aussi comme forme instrumentale indépendante de la danse. Elle n'est pas un des quatre éléments fondamentaux de la suite, mais en fait souvent partie, habituellement parmi les danses facultatives entre la Sarabande et la gigue [...]" In: Ibid., p. 85.

32 In: HARNONCOURT, N. Op.cit., p. 235.

33 "Le branle simple, par exemple, est à 2 temps et s'organise en phrases de 3 ou 6 mesures. Le branle gay est à 3 temps et, au XVIle siècle, il comprend souvent des notes pointées". In: BENOIT, Marcelle. Op.cit., p.89.
} 


\section{d. Canarie}

De estilo semelhante à giga, a canarie se estabeleceu na França no século XVII. Benoit se refere a ela como uma dança muito viva de baile e de cena, em compasso ternário ou binário composto, e ocasionalmente um elemento da suíte barroca. As canaries compostas nos séculos XVII e XVIII têm uma variedade de perfis melódicos e harmônicos. Às vezes apresentada como giga muito viva, a canarie é notada nas fórmulas $6 / 8$ ou $6 / 4$ e reconhecida pelos seus ritmos pontuados. A sua forma é binária e o primeiro compasso de cada frase frequentemente é precedido por um levare ${ }^{34}$.

\section{e. Chaconne}

\section{Brossard define a chaconne como}

uma melodia [chant] composta sobre um baixo obbligato de quatro compassos, comumente em três semínimas, e que se repete tantas vezes quanto a chaconne tenha Couplets ${ }^{35}$ ou Variações, ou seja, as melodias diferentes compostas sobre as notas deste baixo. Passa-se frequentemente do modo maior ao modo menor nesta espécie de peças, e tolera-se muitas

\footnotetext{
34 "Danse de bal et de scène, très vive, en mesure ternaire ou binaire composée, et élément occasionnel de la suite baroque. [...] Les canaries composées aux XVII et XVIIle siècle, ont une variété de profils mélodiques et harmoniques. Parfois présentée comme une gigue très vive, la canarie est notée 6/8 ou 6/4 et se reconnaît par ses rythmes pointés. Sa forme est binaire et la première mesure de chaque phrase est souvent précédée par une levée". In: Ibid., p. 104-105.

35 É necessário o esclarecimento do que são as Couplets ou Variações, já que esse termo é comum ao gênero instrumental francês. Brossard cita: "Falando das simples Chansons ou Árias. É uma palavra tirada do Grego, que significa um certo número de versos, à extremidade do qual se termina um sentido, e/ou portanto, o Compositor deve fazer geralmente uma cadência sobre a nota final do Modo, a menos que a sequência peça-o diferentemente, e em seguida se recomeça outra que tem mesmo número e mesma medida [mesure] de versos, e mesma disposição de rimas, se estes versos forem de uma natureza ou numa língua que pede que eles sejam rimados, etc." "En parlant des simples Chansons ou Airs. C'est un mot tiré du Grec, qui signifie un certain nombre de Vers, au bout duquel on finit un sens, et ou par conséquent le Compositeur doit faire ordinairement une Cadence sur la finale du Mode, à moins que la suite ne le demande autrement, e puis on en recommence une autre qui a même nombre e même mesure de vers, e même dispositions de rimes, si ces vers sont d'une nature, ou dans une langue qui demande qu'ils soient rimez, etc.". In: BROSSARD, Sébastien de. Op.cit., p. 136. Benoit cita: "[...] em música, todas as couplets de uma vaudeville ou uma chanson são cantadas sobre o mesmo ar. [...] Nas formas ostinato, este termo designa cada variação sobre o baixo restrito [obbligato].[...] No Rondeau, couplet designa cada parte nova tocada entre as repetições do refrão." "[...] en musique, tous ces couplets d'un vaudeville ou d'une chanson sont chantés sur le même air. [...] Dans les formes ostinato, ce terme désigne chaque variation sur la basse contrainte. [...] Dans le Rondeau, couplet désigne chaque partie nouvelle jouée entre les répétitions du refrain.". In: BENOIT, Marcelle. Op.cit., p. 190.
} 
coisas devido à esta regra, que não seria regularmente autorizada numa composição mais livre ${ }^{36}$.

A definição de Brossard se encontra em conformidade com as definições tardias. Rameau e d'Alembert, assim como o pesquisador Benoit, utilizam as informações de Brossard, adicionando a ela elementos novos.

Rameau diz que é uma

Ária de dança ou peça instrumental caracterizada por um movimento moderado, uma medida [compasso] em 3 tempos e uma sucessão de couplets construídas sobre um baixo ostinato, agrupadas ou não na forma Rondeau. [...] Ela aparece na França a partir de 1618 [...] no repertório para alaúde[...] $]^{37}$

D'Alembert diz que

A chaconne é uma longa peça de música em três tempos, cujo ritmo é moderado e cujo o metro [tempo] é bem marcado. É composto por um número de couplets que são variadas, tanto quanto possível. [...] Normalmente, a chaconne começa não sobre o primeiro, mas no segundo tempo ${ }^{38}$.

\section{f. Cotillon}

Benoit diz que a palavra cotillon aparece pela primeira vez em 1706, na compilação de danças de baile de Feuillet como uma dança antiga, "maneira de branle à quatre" à moda da Corte. A estrutura da música de cotillon põe em evidência a sua

\footnotetext{
36 "C'est un chant compose sur une basse obligée de quatre mesures, pour l'ordinaire en triple de noires, e qui se répète autant de fois que la Chaconne a de couplets ou de variations, c'est à dire, de chants différents composez sur les notes de cette Basse. On passe souvent dans ces sortes de pièces du Mode majeur au Mode mineur, e l'on tolère bien des choses à cause de cette contrainte, qui ne seraient pas régulièrement permises dans une composition plus libre". In: BROSSARD, Sébastien de. Op.cit., p. 19-20.

37 "Air de danse ou pièce instrumentale caractérisés par un mouvement modéré, une mesure à 3 temps et une succession de couplets bâtis sur une basse obstinée, regroupés ou non en forme rondeau. [...] Elle apparaît en France dès 1618 [...] dans le répertoire de luth. [...]". In: BENOIT, Marcelle. Op.cit., p.122.

38 "The Chaconne is a long piece of music in triple time, whose tempo is moderate an whose metre well marked. It is composed of a number of couplets which are varied as much as possible. [...] Normally the Chaconne begins, not on the downbeat, but on the second beat". In: RAMEAU - D'ALEMBERT apud VEILHAN, J.C. The Rules of Musical Interpretation in the Baroque Era. Paris: Alphonse Leduc, 1979. p.74.
} 
relação com um tipo de chanson tradicional onde o coro retoma a frase do solista, ou seja, sete couplets que se alternam com um refrão ${ }^{39}$.

\section{g. Courante}

Autores do século XVIII, músicos e bailarinos que hoje estudam o estilo e coreografias das courantes permanecem em comum acordo quanto às suas características. Brossard a resume simplesmente em "espécie de dança cuja ária se nota geralmente, em três mínimas, com duas reprises que se recomeçam duas vezes" 40 .

A partir do fim do século XVII, ela passou a ser empregada unicamente como movimento instrumental e não mais como música de dança. Suas características são distintas em duas diferentes espécies de courante: a italiana e a francesa ${ }^{41}$.

Sylvie Bouissou fixa essas características como sendo:

De acordo com as suas origens, um tanto obscuras, apresenta características diferentes guardando ao mesmo tempo uma medida [compasso] ternária, uma estrutura bipartida em reprises (aabb) e um início frequentemente em anacruse sobre a primeira ou a segunda parte do terceiro tempo. A courante francesa, de movimento moderado ou mesmo lento, em $6 / 4$ ou 3/2, é rica em hemiólias ${ }^{42}$, síncopes e outros refinamentos rítmicos e rica de uma textura contrapontística. A courante italiana, de movimento rápido, em 3/4 ou 3/8, segue princípios rítmicos mais simples e desenvolve um material relativamente homofônico ${ }^{43}$.

\footnotetext{
39 "Le nom de cotillon apparaît pour la première fois en 1705 dans le recueil de danses de bal pour I'année 1706 de Feuillet: c'est une danse ancienne, "manière de branle à quatre" à la mode à la Cour. La structure de la musique de cotillon met en évidence son lien avec le type de chanson traditionnelle où le chœur reprendre la phrase du soliste: sept couplets alternant avec un refrain". In: BENOIT, Marcelle. Op.cit., p.184.

40 "espèce de dance dont l'Air se note ordinairement, en triple de blanches, avec deux Reprises qu'on recommence chacune deux fois." In: BROSSARD, Sébastien de. Op.cit., p. 277.

${ }^{41}$ In: HARNONCOURT, N. Op.cit., p. 234.

42 "A relação entre duas quantidades em que uma contém a outra uma vez e meia", como define o Dicionário Houaiss da Língua Portuguesa, sempre esteve presente no vocabulário de quem está mais próximo (de alguma forma) da música setecentista. A hemiola, hemíola, hemiole, hémiole, na língua portuguesa, é grafada como hemiólia e é assim que será dado o emprego deste termo neste trabalho. Dicionário Houaiss da Língua Portuguesa. Rio de Janeiro: Editora Objetiva, 2001.

43 "Selon ses origines, au demeurant obscures, elle présente des caractéristiques différentes tout en gardant un mètre ternaire, une structure bipartite à reprises (aabb) et un début souvent en anacrouse sur la première ou la seconde partie du troisième temps. La courante française, de mouvement modéré voire lent, à $6 / 4$ ou 3/2, est riche en hémioles, syncopes et autres raffinements rythmiques et pourvue d'une texture contrapuntique. la courante italienne, de mouvement rapide, à 3/4 ou 3/8, suit des principes rythmiques plus simples et développe un matériau relativement homophonique". In: BOUISSOU, Sylvie. Vocabulaire de la musique baroque. Montrouge: Minerve, 1996. p.74.
} 
Benoit complementa, dizendo que a courante é uma dança que, em diferentes formas, foi sucesso na França do século XVI até o início do século XVIII, e como forma instrumental independente é um dos elementos fundamentais da suíte barroca. É um dos primeiros elementos-chave da suíte instrumental que segue a allemande ${ }^{44}$.

\section{h. Entrée}

Brossard diz que

São geralmente Prelúdios, ou Symphonies que servem como introdução ou preparação às peças que seguem. Chama-se também deste nome uma Entrée de Ballet, e a Ária que serve para ajustar os passos ${ }^{45}$.

Brossard define a entrée como prelúdio, que é o objeto deste trabalho e da Arte de Preludiar de Hotteterre. A descrição profunda desse gênero será dada mais adiante em lugar adequado.

\section{i. Forlane}

Brossard refere-se à forlane como uma "dança forte" [danse forte], usada em Veneza. Logo em seguida, ele explica o termo forte como "com veemência" sem ser muito forçado. A respeito das características da dança, ele afirma que a forlane é

[...] notada em 6/4, e baseada na repetição de uma frase de estrutura rítmica de dois compassos cujo primeiro é mais ornamentado que o segundo. A estrutura da ária não é binária como na maior parte das danças da época, mas comporta uma reprise de oito primeiros compassos após uma parte central de comprimento variável. As repetições,

\footnotetext{
44 "Danse qui, sous des formes différentes, connaît le succès en France du XVle siècle au début du XVIIIe siècle, et forme instrumentale indépendante qui constitue I'un des éléments fondamentaux de la suite baroque. [...] La sobriété et la régularité de la chorégraphie contrastent avec la complexité de la composition musicale. [...] La courante devient très tôt un des éléments essentiels de la suite instrumentale où elle suit l'allemande. [...] Les compositeurs étrangers (et même français après 1700) écrivent des courantes à la française et à a italienne dans leurs suites, souvent sans distinction de nom". In: BENOIT, Marcelle. Op.cit., p.191-192.

45 "Ce sont ordinairement des Préludes, ou des Symphonies qui servent comme d'Introduction ou de Préparation à celles qui suivent. On appelle aussi de ce nom une Entrée de Ballet, e l'Air qui sert à régler les pas". In: BROSSARD, Sébastien de. Op.cit., p. 50.
} 
dentro da frase, e a nível da frase mesmo, dão à forlane uma simplicidade de expressão que não falta encanto ${ }^{46}$.

\section{j. Gavotte}

\section{Brossard explica que a gavotte}

É uma espécie de dança cuja ária tem duas reprises, a primeira de quatro, e a segunda geralmente de oito compassos a dois tempos; às vezes alegre [gay], às vezes grave. Cada reprise é tocada duas vezes. A primeira, começa en levant [levare] por uma mínima ou duas semínimas ou figuras equivalentes e termina en battant [no tempo], e que cai sobre a dominante ou a mediante do modo, e nunca sobre a [nota] final, a menos que esteja [na forma] Rondeau. A segunda reprise começa também en levant e termina en battant caindo sobre a [nota] final do modo ${ }^{47}$.

James R. Anthony está em conformidade com a definição de Brossard e diz que em ambos, gavotte e bourrée, a unidade de tempo é normalmente a mínima. A primeira seção começa com duas semínimas ou uma mínima, antes do primeiro compasso completo. A inconstância de andamento afirmada por Brossard é também mencionada por Rousseau, que descreve a dança como normalmente graciosa, muitas vezes gay e por vezes bastante lenta e terna ${ }^{48}$.

\footnotetext{
46 "L'air de la forlane typique noté en 6/4, est basé sur la répétition d'une phrase de structure rythmique de deux mesures dont la première est plus découpée que la seconde. La structure de l'air n'est pas binaire comme dans la plupart des danses de l'époque, mais comporte une reprise des huit premières mesures après une partie centrale de longueur variable. Les répétitions, et à l'intérieur de la phrase, et au niveau de la phrase même, donnent à la forlane une simplicité d'expression qui ne manque pas de charme". In: BENOIT, Marcelle. Op.cit., p. 297-298.

47 "C'est une espèce de Dance dont I'Air a deux reprises, la première de quatre, e la seconde ordinairement de huit mesures à deux temps; quelques fois gays, quelques fois graves. Chaque reprise se joue deux fois. La première, commence en levant par une blanche ou deux noires ou notes équivalents e finit en battant, e tombant sur la dominant ou la Médiante du Mode, e jamais sur la Finale, à moins qu'elle ne soit en Rondeau. La seconde reprise commence aussi en levant e finit en battant e tombant sur la finale du mode." In: BROSSARD, Sébastien de. Op.cit., p. 41.

48 "In both the gavotte and the bourrée, the beat is normally the half-note. The first section begins with two quarter-notes or one half-note before the first complete measure. This lack of consistent tempo is also mentioned by Rousseau, who described the dance as ordinarily graceful, often gay, and sometimes rather slow and tender." In: ANTHONY, J.R. French Baroque Music from Beaujoyeulx to Rameau. Oregon: Amadeus Press, 1997. p.135.
} 


\title{
k. Gigue
}

Sobre as características da giga, Brossard diz que "é uma ária para os instrumentos, quase sempre ternária, que é plena de notas pontuadas e sincopadas que a tornam alegre e, por assim dizer, saltada" 49 .

Atualmente, Benoit a descreve como uma

\begin{abstract}
dança rápida em medida [compasso] binária composta. [...] As primeiras gigues são [escritas] em compasso binário simples (geralmente com a fórmula de compasso C) ou compasso binário composto (6/4 ou 6/8), mas este último acaba se impondo. A gigue tem um ritmo rápido, ritmos pontuados, um fraseado irregular; melodia [dessus] e baixo são frequentemente escritos em imitação. [...] No final do século XVII aparecem na França as gigas inspiradas na giga italiana, especialmente aquelas do violinista Corelli. A giga italiana é diferente da [giga] francesa pela fórmula de compasso (geralmente em 12/8), pela sucessão de colcheias iguais no lugar de ritmos pontuados, pela ausência de imitação, e pelo fraseado mais regular e harmonias mais simples ${ }^{50}$.
\end{abstract}

Através da explicação de Benoit fica claro que as características citadas por Brossard pertencem à giga francesa.

\section{Loure}

Muitos autores definem a loure como uma giga mais lenta ${ }^{51}$. No entanto, para que não se restrinjam as características dessa dança às da giga somente, Sylvie Bouissou a descreve como uma dança francesa de movimento grave e pesado, escrita em compasso $6 / 4$ ou às vezes $3 / 4$, e frequentemente definida como giga lenta,

\footnotetext{
49 "C'est un air ordinairement pour les instruments, presque toujours en triple qui est plein de notes pointées e syncopées qui en rendent le chant gay, e pour ainsi dire sautillant". In: BROSSARD, Sébastien de. Op.cit., p. 42.

50 "Danse rapide en mesure binaire composée. [...] Les premières gigues sont en mesure binaire simple (généralement $C$ ) ou en mesure binaire composées (6/4 ou 6/8), mais cette dernière finit par s'imposer. La gigue a un tempo rapide, des rythmes pointés, un phrasé irrégulier; dessus et basse y sont souvent en imitation. [...]À la fin du XVIle siècle des gigues inspirées de la giga italienne, surtout celles du violoniste Corelli, font leur apparition en France. La gigue à l'italienne se distingue de la française par la mesure (généralement 12/8), la succession de croches égales au lieu des rythmes pointés, I'absence d'imitation, le phrasé plus régulier et les harmonies plus simples". In: BENOIT, Marcelle. Op.cit., p. 319.

51 In: ANTHONY, J.R. Op.cit., p.135.
} 
iniciando geralmente em anacruse de uma colcheia sobre a segunda metade do segundo tempo ${ }^{52}$.

m. Marche

A respeito da marche, Bouissou diz que é uma

Ária de dança geralmente de estrutura bipartida com reprises, escrita num estilo simples e vertical e podendo ser de medida [compasso] binária ou ternária. No teatro lírico, a marche preenche mais ou menos a mesma função que a entrée ${ }^{33}$.

\section{n. Menuet}

As árias de menuet (ou minuetos, na língua portuguesa) aparecem na suíte instrumental no fim do século XVII. A suíte, que se estabelece na França nas primeiras décadas do século XVIII, insere, entre a sarabande e a giga, um ou dois minuetos entre as danças facultativas ${ }^{54}$.

Brossard se refere aos minuetos como:

dança forte [gay], que vem originalmente de Poitou. Deve-se à imitação dos italianos a utilização da fórmula de compasso 3/8 ou 6/8 para marcar o movimento, que ainda é muito forte [gay] e forte rápida [vite], mas o uso da fórmula de compasso por um simples 3 ou três semínimas prevaleceu. A ária desta dança tem normalmente duas reprises que são tocadas duas vezes cada. A primeira tem 4 ou 8 compassos cujo ultimo deverá acabar sobre a dominante, ou pelo menos na mediante do modo, e nunca sobre a [nota] final, salvo se estiver na [forma] Rondeau. A segunda reprise é normalmente de 8 compassos cuja última

52 "Danse française de mouvement grave et pesant, écrite dans une mesure à $6 / 4$ ou parfois à 3/4 . Souvent définie comme une gigue lente, elle commence généralement en anacrouse d'une croche sur la seconde moitié du deuxième temps". In: BOUISSOU, Sylvie. Op.cit., p. 117.

53 "Air de danse le plus souvent de structure bipartite à reprises, écrit dans un style simple et vertical et pouvant être de mesure binaire ou ternaire. Dans le théâtre lyrique, la marche remplit à peu prés la même fonction que l'entrée." In: Ibid., p. 123.

54 "Dans la suite instrumentale, le menuet fait son apparition vers la fin du XVII siècle, de façon d'abord occasionnelle, puis de plus en plus systématique. La suite type qui s'établit dans les premières décennies du XVIII siècle, à l'étranger plus qu'en France, insèrent entre la sarabande et la gigue un ou deux menuets parmi les danses facultatives". In: BENOIT, Marcelle. Op.cit., p. 451-452. 
deve terminar sobre a [nota] final do modo, e é uma mínima pontuada ou um compasso inteiro $^{55}$.

Bouissou destaca que d'Alembert, em sua Encyclopédie ou Dictionnaire raisonné des sciences, des arts et des métiers, publicado em Paris em 1751, fala de um minueto mais 'moderado's6 em seu movimento, em oposição ao minueto 'rápido' citado por Brossard. Sobre essa transição de movimento, Harnoncourt comenta que Saint-Simon aponta um motivo concreto para ela. O Rei Luís XIV, envelhecendo, ordenou que os minuetos fossem tocados mais lentamente, pois ele encontrava dificuldade para dançar, e assim, essa regra foi imitada em toda a França ${ }^{57}$.

\section{o. Passacaille}

Segundo Brossard, a passacaille

É exatamente uma chaconne. A diferença é que o movimento é geralmente mais grave do que aquele da chaconne, a melodia [chant] mais terna, e as expressões menos vivas, é por isso que as passacailles são quase sempre trabalhadas sobre modos menores, ou seja, das quais a mediante é afastada da [nota] final por uma terça menor ${ }^{58}$.

Muitos autores, além de Brossard, atribuem as características da passacaille às da chaconne. Quantz, após comentar sobre as características da chaconne, faz menção à passacaille dizendo: "uma passacaille é como o tipo precedente [chaconne], mas é

\footnotetext{
55 "Danse fort gaye, qui nous vient originairement du Poitou. On devrait à l'imitation des Italiens se servir du signe 3/8 ou 6/8 pour en marquer le mouvement, qui est toujours fort gay e fort vite; mais I'usage de le marquer par un simple 3 ou triple de noires a prévalu. L'air de cette danse a ordinairement deux reprises qui se jouent chacune deux fois. La première a 4 ou tout au plus 8 mesures dont la dernière doit tomber sur la dominante, ou du moins sur la Médiante du Mode, e jamais sur la Finale, à moins qu'il ne soit en Rondeau. La seconde reprise est ordinairement de 8 mesures dont la dernière doit tomber sur la Finale du Mode, e est une blanche pointée ou une mesure entière". In: BROSSARD, Sébastien de. Op.cit., p. 60.

56 "Danse française de mesure ternaire (mais battue à deux temps), qui commence sur le premier temps et se joue dans un mouvement modéré (D'Alembert) ou rapide (Brossard)". In: BOUISSOU, Sylvie. Op.cit., p. 125.

${ }^{57}$ SAINT-SIMON apud HARNONCOURT, N. Op.cit., p. 235.

58 "C'est proprement une Chaconne. Foute la différence est que le mouvement en est ordinairement plus grave que celui de la Chaconne, le Chant plus tendre, e les expression moins vives, c'est pour cela que les passacailles sont presque toujours travaillées sur des modes mineurs, c'est à dire, dont la Médiante n'est éloignée de la Finale que d'une tierce mineure". In: BROSSARD, S. Op.cit., p. 89.
} 
tocada um pouco mais rápido" 59 . Anthony comenta: "ambas as danças são organizadas em frases de quatro ou oito compassos e são compostas de contínuas variações, ao longo de um padrão repetido da linha do baixo" 60 .

Jean-Claude Veilhan comenta que

\begin{abstract}
Muitos escritores do período [século XVIII] concordam em dar à passacaille um tempo mais lento que o da chaconne, em suítes instrumentais. A contrariedade de Quantz, em dizer que a passacaille tem que ser tocada mais rápido que a chaconne, se deve ao fato dele estar se referindo a passacaille dançada ${ }^{61}$.
\end{abstract}

\title{
p. Passepied
}

Segundo Brossard, o passepied é muito semelhante ao minueto ${ }^{62}$. Já Bouissou, em sua pesquisa para o verbete passepied, cita que é uma dança francesa originária da Bretanha, considerada por Arbeau no seu Orchésographie como uma branle de movimento moderado e de compasso binário. O passepied se transforma durante o século XVII em dança viva de medida ternária $(3 / 8,6 / 8)$ com um início em anacruse sobre o terceiro tempo. Mais rápida que o menuet, pelo contrário, cultiva de boa vontade a hemiólia que favorece o seu caráter jovial. Obedece a uma estrutura bipartida em reprises de tipo (aabb). Assim como a gavotte, o menuet e o rigaudon, apresenta-se em pares de danças opostas pelos seus modos maior e menor com reprise da primeira dança ${ }^{63}$.

\footnotetext{
59 "A passacaille is like the preceding type, but is played just a little faster." In: QUANTZ, J.J. Op.cit., p. 291.

60 "Both dances are organized in phrases of four or eight measures and are composed of continuous variations over a repeated bass line pattern". In: ANTHONY, J.R. Op.cit., p. 137.

61 "Most writers of period agree in giving the passacaille a slower tempo than that of the chaconne (in instrumental suites). Quantz's contrary view seems to refer to the passacaille for dancing". In: VEILHAN, J.C. Op.cit., p. 86.

62 "É um minueto cujo movimento é forte-vivo, forte-alegre." "C'est un menuet dont le mouvement est fort-vite et fort-gay". In: BROSSARD, S. Op.cit., p. 303.

63 "Danse française originaire de Bretagne, considérée par Arbeau dans son Orchésographie comme un branle de mouvement modéré et de mesure binaire. Le Passepieds se transforme au cours du XVIIe siècle en danse vive de mesure ternaire $(3 / 8,6 / 8)$ avec un début en anacrouse sur le troisième temps. Plus rapide que le menuet, au contraire de celui-ci il cultive volontiers l'hémiole qui favorise son caractère enjoue. II obéit à une structure bipartite à reprises de type (aabb). De même que la gavotte, le menuet ou le rigaudon, il se présente en couple de danses opposées par leurs modes majeur et mineur avec reprise de la première danse". In: BOUISSOU, Sylvie. Op.cit., p. 162.
} 
Sobre as características do passepied, Benoit completa dizendo que este possui um levare de uma colcheia, frases de 8 compassos (4+4) e frequentemente pequenas sequências de semicolcheias. O emprego da hemiólia é frequente, sobretudo, mas não exclusivamente, ao aproximar de uma cadência ${ }^{64}$.

\section{q. Rigaudon}

Anthony define o rigaudon como uma dança rápida em dois, que, de acordo com Compan, foi 'muito popular na Provença'. Assemelha-se a bourrée, embora a sua estrutura de frase seja simples, e ela quase sempre inicie com duas mínimas seguindo uma semínima em anacruse ${ }^{65}$.

Bouissou explica que é uma dança de movimento vivo e compasso binário; a sua estrutura compreende duas partes constituídas de um número de compassos múltiplos "de quatro" e reprises cada uma de acordo com o esquema [aabb]. Cada reprise começa em anacruse sobre a última nota do segundo tempo e marca uma tendência a uma harmonia estável no início da frase que acelera as suas mudanças de acordes em fim de frase. Como o tambourin ou a bourrée, apresenta-se frequentemente em pares de danças opostas pelos seus modos maiores e menores com reprise da primeira dança ${ }^{66}$.

\section{r. Sarabande}

Sobre a sarabande, Harnoncourt afirma que é nela que melhor se observa a transformação de uma dança rápida em lenta. Originária provavelmente do México ou da Espanha, foi conhecida na Europa, por volta de 1600, como uma canção dançada, licenciosa e erótica. De início proibida - os cantadores de sarabandas, na Espanha de Felipe II, arriscavam-se a pesadas penas de prisão -, a sarabanda já na primeira metade

\footnotetext{
64 "Une levée d'une croche, des phrases de huit mesures (4+4), et souvent de petites suites de doubles croches. L'emploi de I'hémiole est fréquent, surtout, mais pas exclusivement, à I'approche d'une cadence". In: BENOIT, Marcelle. Op.cit., p. 540-541.

65 "the Rigaudon is a fast dance in duple meter, which, according to Compan, was 'very popular in Provence'. It closely resembles the bourrée, although its phrase structure is simpler, and it almost always begins with two half-notes following the quarter-note upbeat". In: ANTHONY, J.R. Op.cit., p. 136.

66 "De mouvement vif et de mesure binaire, sa structure comprend deux parties constituées d'un nombre de mesures multiples de 'quatre' et reprises chacune une fois selon le schéma aabb. Chaque reprise commence en anacrouse sur la dernière note du second temps et marque une tendance à une harmonie stable en début de phrase qui accélère ses changements d'accords en fin de phrase. Comme le tambourin ou la bourrée, il se présente fréquentemment en couple de danses opposées par leurs modes majeur et mineur avec reprise de la première danse" In: BOUISSOU, Sylvie. Op.cit., p. 177.
} 
do século XVII foi liberada e era dançada com arrebatamento e selvageria nas cortes francesa e espanhola ${ }^{67}$.

Sobre as suas características, Anthony diz que normalmente a sarabande está estruturada em frases de quatro compassos, muitas vezes com pesado acento no segundo tempo e com uma hemiólia ocasionalmente encontrada em compassos que precedem uma cadência ${ }^{68}$.

\subsection{Agréments e Ornements}

Um aspecto importante em que a música francesa se diferenciava da italiana no século XVIII era a ornamentação. Na França, fazia-se uso de dois termos para designar ornamentação: agrément e ornement. Porém, mesmo para o período, a utilização desses termos era carente de exatidão.

Brossard, em seu dicionário de música, associa o termo agrément aos termos italianos figura, diminutione e coloratura; já para o termo ornement, Brossard atribui o termo couleur [cor] e em seguida sugere uma relação com os termos italianos coloratura, chroma e figura, o que pode fazer com que alguns autores subentendam esses termos como sinônimos e outros iniciem uma discussão acerca do verdadeiro sentido de um termo e de outro.

Bouissou explica que "certos teóricos tentaram diferenciar agrément notado (port de voix, accent, coulé, etc.) e ornement improvisado atribuindo ao primeiro uma função essencial e ao segundo uma função arbitrária do tipo variado"69.

Pode-se dizer que, na música francesa, a ornamentação consiste, em sua maior parte, na aplicação de uma grande variedade de ornamentos fixos (agréments). A palavra advém de agrément du chant, que no início do século XVIII era sinônimo do termo italiano coloratura, utilizado para fazer referência a todas as figuras de

\footnotetext{
67 In: HARNONCOURT, N. Op.cit., p. 236.

68 "Typically, the sarabande is structured in four-measure phrases, often with a heavily accented second beat and with a hemiola occasionally found in the measures preceding a cadence". In: ANTHONY, J.R. Op.cit., p. 136-137.

69 "certains théoriciens ont tenté de différencier 'agrément' noté (port de voix, accent, coulé, etc.) et 'ornement' improvisé en accordant aux premiers une fonction essentielle et aux seconds une fonction arbitraire de type variationnel." In: BOUISSOU, Sylvie. Op.cit., p. 18.
} 
ornamento fixas, notadas, do canto. Porém, ornamentos [ornements] mais longos e mais livres também estavam presentes e eram chamados de broderies [bordados] e passages [passagens]. Brossard associa as broderies ao termo italiano diminutione, ou diminuição, que para ele é quando se divide, por exemplo, uma semibreve ou uma mínima em muitas semínimas ou colcheias, ou em outras notas de menor valor. Existem várias maneiras, todas por graus conjuntos, como os trinados, tremolos, grupettos, etc. ${ }^{70}$

Brossard também associa a palavra passage a outro termo italiano, passaggio, definindo-o como "uma sequência melódica [du chant] composta de várias pequenas notas como colcheias, semicolcheias, etc., que dura no máximo um, dois, ou três tempos"71. Essa é exatamente a diminuição, a maneira de improviso e ornamentação descrita por tratados italianos como o La Fontegara - do veneziano Silvestro Ganassi, publicado em 1535 -, o I/ vero Modo di Diminuir con tutte le sorte di stromenti di fiato et corda et di voce humana - de Girolamo Dalla Casa, publicado em 1584 -, o II Transilvano - de Girolamo Diruta, publicado em 1593 - etc.

Essa relação transparente com termos italianos nos sugere que a prática da ornamentação italiana, uma ornamentação livre derivada da prática da diminuição dos séculos XVI e XVII², também estava presente na prática da música francesa.

A esse respeito, Mather e Lasocki ${ }^{73}$ afirmam que esse tipo de ornamentação estava frequentemente presente nos prelúdios franceses, que se tornaram cada vez mais floridos na primeira metade do século XVIII, como por exemplo nas obras do flautista Michel de La Barre, do compositor Joseph Bodin de Boismortier (1689-1755) e principalmente na obra de Jacques Martin Hotteterre - Le Romain ${ }^{74}$.

A ornamentação fixa (notada) é característica da música francesa, e sua notação aparece no século XVII no Harmonie Universelle de Marin Mersenne, mais

\footnotetext{
70 "C'est lorsqu'on partage par exemple, une ronde ou une blanche en plusieurs Noires ou croches, ou autres notes de moindre valeur. II y en a de plusieurs manières. On en fait par degrés conjoints, comme les trilli, tremoli, groppi, fioretti, tirate, etc." In: BROSSARD, S. Op.cit., p. 29-30.

71 "C'est une suite de chant composée de plusieurs petites notes comme croches, doubles croches, etc., qui dure une, deux, ou trois mesures tout au plus". In: Ibid., p. 89.

72 Sobre a prática italiana de diminuição cf. GANASSI, Silvestro. Opera Intitulata Fontegara (Venice, 1535).

73 MATHER, B. B.; LASOCKI, David. Free Ornamentation in Woodwind Music 1700-1775: an Anthology with Introduction. New York: McGinnis \& Marx, 1976.

74 "French Preludes often include such ornamentations. Preludes became more florid during the first part of the century, as shown in examples by La Barre, Hotteterre and Boismortier". In: MATHER, B. B.; LASOCKI, David. Op.cit., p. 11.
} 
precisamente em 1636, e se estende até a segunda metade do século XVIII, no Principes de la Musique Pratique de Pierre Duval, publicado em 1764. Contudo, Bouissou mostra em seu estudo que os sinais que indicam os ornamentos não são univocamente codificados. A autora demonstra que cada mestre utilizou sinais próprios e arbitrários, e sugere que eles tenham sido criados para uso exclusivo de seus discípulos ${ }^{75}$.

Ann Bond, em 1997, refere-se aos ornamentos fixos como agréments. Sobre eles, diz que apesar de não haver uma padronização total, a maioria dos compositores, inclusive Hotteterre, utilizavam os símbolos de Chambonnière completados pelos símbolos de Couperin, ou os sinais de d'Anglebert, mais próximos daqueles utilizados nas tablaturas de alaúde. Nessa segunda categoria insere-se Rameau ${ }^{76}$.

Bond e Bouissou estabelecem distinção entre os termos agrément e ornement. Para ambas, agrément representa a ornamentação notada, oriunda dos agréments du chant, enquanto ornement designa a ornamentação livre, improvisada, oriunda da ornamentação italiana.

Como consequência da diversidade de símbolos em uso, compositores franceses utilizaram diferentes símbolos, o que resultou na necessidade de se esclarecer que símbolos seriam adotados e como se daria a execução de cada um dos agréments.

Hotteterre, seguindo esse princípio, também apresenta no prefácio da sua segunda obra Premier Livre de Pièces pour la flûte traversière ${ }^{77}$ uma table des agréments, indicando como devem ser executadas as suas figures des agréments. Essa tabela serve como referência para a aplicação de ornamentos em toda a sua obra. Lemos abaixo o texto completo apresentado por Hotteterre:

\footnotetext{
75 "[...] chaque maître, dans ses leçons particulières, se sert de signes à son choix [...] d'ailleurs, les mêmes signes n'étant pas admis pas tous, chaque maître en a imaginé qui ne peuvent servir qu'à leurs disciples." DUVAL, Pierre apud BOUISSOU, Sylvie. Op.cit., p. 18.

${ }^{76}$ Cf. BOND, Ann. Op.cit., p. 161.

77 HOTTETERRE, J. M. Premier Livre de Pièces pour la flûte traversière. Paris, 1708 (Nouvelle Edition. Paris, 1715). Edição fac-similar. Florença: S.P.E.S, 1980.
} 


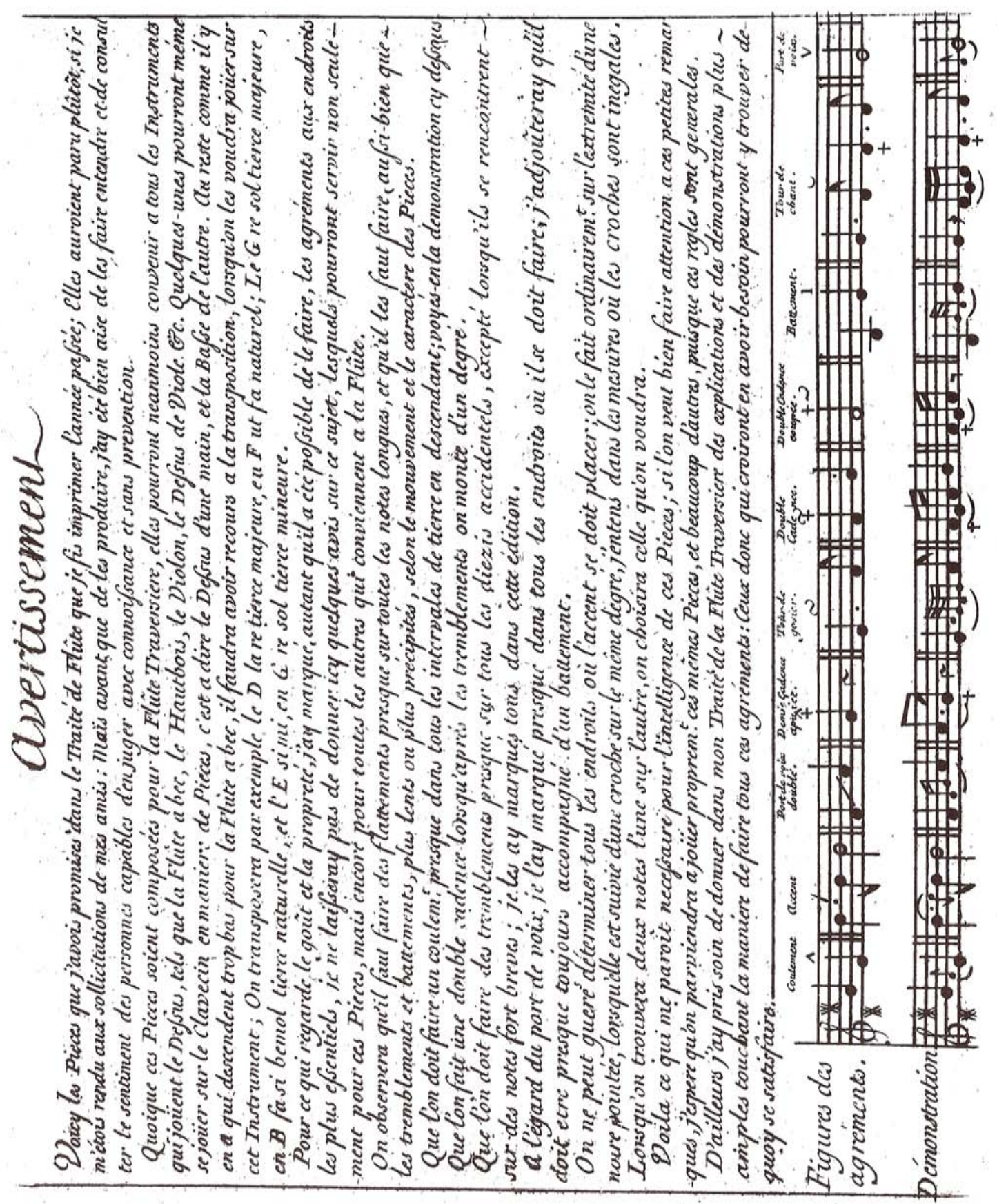

Figura 1.1.: Advertência do primeiro livro de peças para flauta traversa ${ }^{78}$.

78 HOTTETERRE, J. M. Op. cit., p. 1. 
Advertência

Aqui estão as peças que eu havia prometido no tratado de flauta que publiquei no ano passado; elas teriam aparecido antes se eu não tivesse atendido às solicitações dos meus amigos: mas antes de publicá-las, fiquei bem satisfeito em fazê-los ouvir e em consultar os sentimentos das pessoas capazes de julgar com conhecimento e sem prejulgamentos.

Embora estas peças sejam compostas para a flauta traversa, poderão no entanto convir para todos os instrumentos que tocam a melodia [le dessus], como a flauta doce, o oboé, o violino, a viola da gamba soprano [dessus de viole], etc. Algumas podem até mesmo ser tocadas no cravo, ou seja, a melodia [le dessus] com uma mão, e o baixo com a outra. De resto, para as que forem muito graves para a flauta doce, deve ser utilizado o recurso da transposição, quando se quiser tocar neste instrumento; transpõe-se por exemplo o [modo] de $D$ la ré terça maior, para $F$ ut fá natural; o $G$ ré sol terça maior para $B$ fá si bemol terça natural, e o [modo] de E si mi em G ré sol terça menor.

No que diz respeito ao gosto [goût] e à elegância [propreté], eu marquei, da melhor forma possível, os ornamentos [agréments] mais essenciais; não vou deixar de dar aqui quaisquer avisos sobre este assunto, que poderão ser utilizados não só para estas peças, mas também para todas as outras que convêm à flauta.

Observar-se-á que temos que fazer os flattements sobre quase todas as notas longas, e que se deve fazê-los assim como os tremblements e os battements, mais lentos ou mais apressados, segundo o movimento e a característica das peças.

Deve-se fazer um coulement em quase todos os intervalos de terça descendente [...]. Deve-se fazer uma double cadence, onde, depois dos tremblements, se sobe um grau. Deve-se fazer os tremblements em quase todos os sustenidos ocorrentes [fora da armadura de clave], exceto naqueles que se encontram em notas muito breves [curtas]; marquei todos estes [agréments] nesta edição.

A respeito do port de voix, marquei em quase todos os lugares onde se deve fazê-lo; acrescentaria que ele deve ser quase sempre acompanhado por um battement.

Dificilmente podem-se identificar todos os locais onde devem ser colocados os accents; geralmente devem ser utilizados no fim de uma semínima pontuada, quando esta é seguida de uma colcheia sobre o mesmo grau, ou seja, em todos os compassos [medidas] onde as colcheias são desiguais [inégales]. Quando se tem duas notas, uma sobre a outra, escolhe-se aquela que se quer.

Eis o que me parecia necessário para uma compreensão destas Peças; observando essas pequenas indicações, espero que cheguemos a uma conveniente execução destas peças, e de muitas outras, uma vez que estas regras são gerais. Por outro lado, tive o cuidado de incluir no meu tratado de flauta traversa uma explicação e demonstração mais ampla da forma de tocar todos esses ornamentos [agréments]: aqueles que tiverem necessidade [de mais informações], lá poderão encontrar algo que poderá contentá- ${ } \mathrm{s}^{79}$.

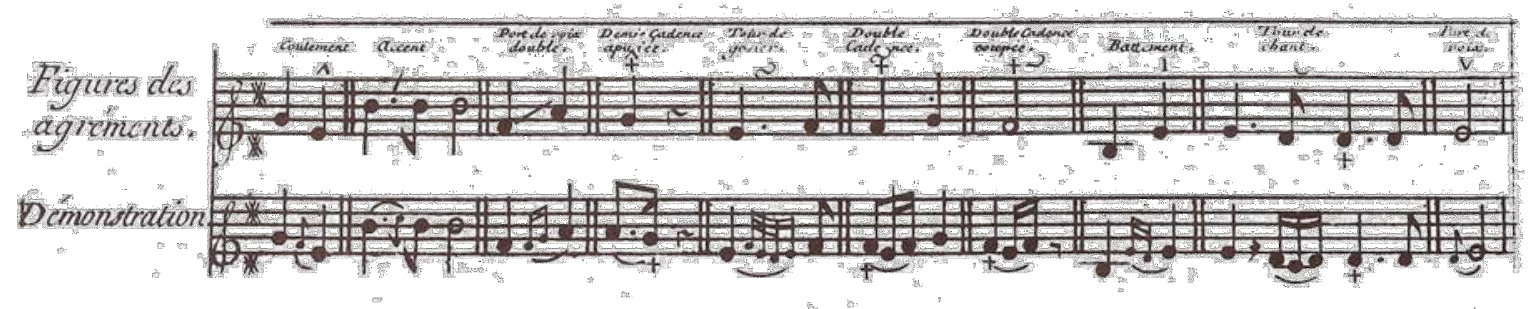

Figura 1.2.: Imagem extraída da advertência do primeiro livro de peças para flauta traversa ${ }^{80}$.

79 Prefácio do Premier Livre de Pièces pour la flûte traversière de Jacques Martin Hotteterre - Le Romain. In: HOTTETERRE, J. M. Op. cit.

80 HOTTETERRE, J. M. Op. cit., p.1. 
Nesse texto, Hotteterre descreve e exemplifica diversos tipos de ornamentos fixos, sobre os quais discorrerei a seguir. A indicação de considerarmos as informações dadas por ele na sua primeira obra, o tratado de flauta traversa ou Principes de la Flûte Traversière, publicado em Paris em 1707, para que se possa ter mais informações a respeito das figuras de ornamentação é extremamente importante. É necessário sabermos exatamente qual era o seu pensamento a respeito da execução da ornamentação para uma interpretação mais verossímil de sua obra.

O vibrato de dedo (flattement), o primeiro ornamento descrito por Hotteterre, é muito utilizado na música instrumental francesa. Jean-Claude Veilhan ${ }^{81}$ seguiu as indicações de Hotteterre e elaborou duas tabelas de dedilhados para flattements e battements (vide anexo) e as acrescentou, juntamente com a table des cadences elaborada por Hotteterre, em seu trabalho.

A pesquisadora Betty Bang Mather é autora de uma das mais importantes pesquisas $^{82}$ sobre a interpretação da música francesa entre 1675 e 1775 . No capítulo em que discorre sobre ornamentação, ela confronta as informações de Hotteterre com outras fontes primárias setecentistas. As informações que se seguem baseiam-se nessa pesquisa.

O primeiro ornamento exemplificado na figura apresentada por Hotteterre é o chamado coulement, que na pesquisa de Mather pertence à classe do port de voix. Se prestarmos atenção ao primeiro e ao último sinal indicativo da table de Hotteterre, entendemos a razão pela qual Mather une os dois ornamentos em uma categoria única em seu estudo. Mather afirma que, na França, o port de voix "era um termo geral que designava todas as notas individuais e duplas que subiam ou desciam por graus conjuntos às notas que as seguiam" ${ }^{83}$. A autora menciona que os ports de voix franceses podem ter appoggiatura simples ou dupla, ascendentes ou descendentes ${ }^{84}$. O termo port de voix simple, ou simplesmente port de voix, designa a appoggiatura simples ascendente. Coulé, port de voix descendent, coulement, ou ainda chûte, especifica a appoggiatura simples descendente por grau conjunto para a próxima nota

\footnotetext{
81 VEILHAN, Jean-Claude. La Flûte à bec Baroque selon la Pratique des XVIle et XVIIle siècles. Paris: Alphonse Leduc, 1980.

82 MATHER, B.B. Interpretation of French Music from 1675 to 1775: for woodwind and other performers. New York: McGinnis e Marx, 1973.

83 "was a general term designating all single and double grace notes which ascended or descended by step to the notes following them". In: MATHER, B.B. Op. cit., p. 53.

${ }^{84}$ Cf. MATHER, 1973.
} 
seguinte. Finalmente, port de voix double designa a appogiatura dupla que normalmente é ascendente, como mostra o terceiro exemplo da tabela de Hotteterre.

O segundo exemplo da figura de Hotteterre é o accent. Mather afirma que esse ornamento era inicialmente utilizado por cantores, e que seu ritmo inicialmente não era bem definido. Era geralmente realizado com a nota superior à nota ornamentada. $\mathrm{O}$ accent soava como uma triste aspiração ou elevação da voz, uma espécie de soluçar ${ }^{85}$. Hotteterre observou apenas que o ornamento era usado para dar às notas mais expressão.

O quarto exemplo da figura de Hotteterre é a demie cadence appuie, que Mather inclui no grupo do tremblement. Ela diz que o tremblement, também chamado de cadence (cadência), foi o termo francês geral para trinado (trill) - uma alternância entre a nota principal e a nota acima da nota principal. Esse trinado quase sempre começa na nota acima da nota principal ${ }^{86}$.

A respeito dos tipos de tremblement ou cadence ${ }^{87}$, a autora faz referência ao tremblement simple, que nada mais é que um trinado sem preparação ou finalização; ao tremblement lié, que é um simples trinado cuja nota anterior está ligada ao grau conjunto superior; ao tremblement détaché, um trinado simples cuja nota anterior é separada (détaché); à demi cadence, que é um meio trinado, ou seja, um trinado curto, constituído de apenas quatro notas; à cadence feinte, que é uma cadência incompleta, ligada ao meio trinado, precedida pela nota acima e ligada a essa nota cujo 'agitar' foi reduzido para três notas; e finalmente a demie cadence appuie, que é um trinado em que a nota superior foi sensivelmente mantida, atrasando assim o início do 'agitar'. Esse procedimento é considerado como uma preparação do trinado e não deve ser confundido com a prática normal de início de todos os trinados na nota superior ${ }^{88}$.

\footnotetext{
85 "was an ornament used by singers and, according to Montéclair, neither its pitch nor its rhythm was well defined. It was usually, but not always, made on the note above the ornamented note. It always occurred at the very end of the note and took its time from that note. [...] The accent was a sorrowful aspiration or elevation of the voice - a kind of sob, according to Montéclair. He said it was more often used in plaintive airs than in tender ones and was never used in gay pieces or those expressing anger. Hotteterre merely remarked that the ornament was used to give notes more expression". In: Ibid., p. 77-78.

86 "The tremblement (also called cadence) was the general French term for trill - an alternation of the main note and the note above the main note. This trill almost always began on the note above the main note". In: Ibid., p.67.

87 associação feita também por Hotteterre em seu Principes de la flûte traversière (Paris, 1707).

${ }^{88}$ Cf. MATHER, 1973. p. 67.
} 
A respeito da double cadence, o sexto exemplo na figura de Hotteterre, também chamada de tremblement tourné, Mather afirma que "[...] era um trinado com duas notas de finalização - um tom ou meio tom abaixo da nota principal. Pode ser escrito como figuras normais ou como ornamento (appoggiatura). Pode ser indicado por um sinal ou ser adicionado em qualquer trinado ascendente, quando o tempo permite" 89 .

No que toca ao sétimo exemplo da figura de Hotteterre, a double cadence coupée, é intrigante perceber que Mather não utiliza esse termo quando se refere à cadence feinte, pois ambas possuem o mesmo significado. Esse ornamento, que tira seu nome do francês coupée (cortada), é composto de um trinado ligado a uma terminação sem resolução, ou seja, uma cadence feinte.

O quinto exemplo da figura de Hotteterre, o tour de gousier [gosier, na grafia do século XVIII], é definido por Mather como aparentemente idêntico ao termo italiano grupetto e ao termo inglês turn. Consiste de uma volta em torno da nota principal - a nota acima da nota principal, a principal nota em si, a nota abaixo da nota principal, e o retorno à nota principal. O retorno final para a nota principal é às vezes parte do ornamento e às vezes indicada ${ }^{90}$.

O battement, o oitavo exemplo de Hotteterre, é incluído por Mather no grupo denominado genericamente como pincé. Ela diz que "pincé ou battement foi a palavra francesa [utilizada] para mordente". Esse ornamento é uma rápida alternância entre a nota principal e a nota inferior ${ }^{91}$. Alguns compositores sugerem a realização de um port de voix antecedendo a execução dessa figura ${ }^{92}$.

Finalizando com o nono exemplo da figura da tabela de Hotteterre, o tour de chant, Mather explica que consiste em "uma volta melódica usada como uma preparação para o trinado" ${ }^{\prime 93}$.

Esse extenso esclarecimento acerca da prática da ornamentação da música instrumental francesa é indispensável para a execução da obra de Hotteterre e,

\footnotetext{
89 "[...] was a trill with two closing notes - one a whole or half step below the main note, the other the main note. It could be written out as ordinary notes or as grace notes. It could be indicated by a sign, or it could be assumed in any ascending trill when time allowed". In: Ibid., p. 68.

90 "The tour de gosier was seemingly identical to the Italian grupetto and the English turn. It consisted of a turn around the main note, the note above the main note, the main note itself, the note below the main note, and a return to the main note. The final return to the main note was sometimes part of the ornament and sometimes indicated as the following ordinary note". In: Ibid., p. 76.

91 "Pincé or battement was the French word for mordent. This ornament consisted of a rapid alternation of the main note and the note below". In: Ibid., p. 74.

${ }^{92}$ Cf. Ibid., p. 75.

93 "The tour de chant was a melodic turn used as preparation for a trill". In: Ibid., p. 79.
} 
principalmente, no que diz respeito à prática dos exemplos de prelúdios dispostos por ele em seu tratado L'Art de Préluder.

\subsection{Pointer}

Sobre essa desigualdade de notas escritas de maneira igual, Robert Donington ${ }^{94}$ nos fornece informações sobre o que cada um dos importantes autores dos séculos XVI, XVII e XVIII falam sobre o assunto. Abaixo segue cada uma das citações cotadas por Donington sobre essa desigualdade das notas ou, como alguns autores preferem denominar, inégalité.

Loys Bourgeois, Genebra, 1550: essa desigualdade significa tocar colcheias, duas em duas, demorando mais [tempo] na primeira do que na segunda.

Girolamo Frescobaldi, Roma, 1615/16: Tocar a segunda de cada par de semicolcheias um pouco pontuada.

Giovanni Domenico Puliaschi, Roma, 1618: Tocar pares igualmente notados ora pontuando a primeira nota, ora a segunda, como requer a passagem.

Anônimo Inglês por volta de 1660: Desiguale roubando metade do tempo de uma das notas e conceda essa metade à próxima.

Bénigne de Bacilly, Paris, 1668: De duas notas, uma é geralmente pontuada; mas isto não foi marcado [notado] com receio de ser tocado por idiotas; para estes, em muitos casos, é necessário ser [notado] pontuado, mas com a restrição de que não é exatamente pontuado, e ainda assim, em algumas passagens, é mesmo necessário a [notação] pontuada.

Roger North, inglês, por volta de 1690: Em notas curtas, desigualdade dá vida e espírito para o movimento; e não notar [escrever isto] é uma boa maneira de obter este efeito.

Georg Muffat, Augsburg, 1693: Em compassos binários lentos, diversas colcheias continuadas em sucessão não devem ser desiguais para a elegância da performance, pois elas normalmente seriam 'em tempo comum'.

Alessandro Scarlatti, Nápoles, 1694: 'Alguém toca em tempo igual' e as colcheias notadas iguais em uma passagem podem ser, de outra maneira, encaradas como um convite à desigualdade.

94 DONINGTON, Robert. Baroque Music: Style and Performance. New York: W. W. Norton, 1982. 
Étienne Loulié, Paris, 1696: Em cada medida [compasso], mais especialmente no compasso ternário, as metades dos tempos [colcheias] são tocadas de duas diferentes maneiras, embora elas sejam notadas da mesma maneira. 1. Elas são às vezes feitas iguais como em melodias onde há saltos e em muitos dos tipos de música estrangeira onde você nunca deve fazer [a desigualdade] exceto onde for marcado. 2. Às vezes, a primeira metade do tempo pode ser feita um pouco mais longa como em melodias que se movem por graus conjuntos. Alternativamente, a primeira metade do tempo é feita mais longa do que a segunda, mas a primeira metade deveria neste caso ser notada [escrita] com um ponto.

Michel de Saint-Lambert, Paris, 1702: Algumas notas são feitas desiguais porque a desigualdade nos dá mais graça, mas nenhuma regra é fechada, porque o gosto julga como fazer o tempo.

Michel de Montéclair, Paris, 1709: Notas tendem a ser iguais em [compassos] C, 2/4, e 3/8 mas desiguais em compassos com a fórmula 3. No entanto, sobre isso, é muito difícil dar princípios gerais porque é o estilo das peças para serem cantadas que o decide; mas as notas que têm quatro em um tempo [semicolcheias] são entendidas para serem desiguais, a primeira um pouco mais longa que a segunda; ou duas para um tempo [colcheias] em movimentos lentos de tempo ternário.

François Couperin, Paris, 1716/17: Nós escrevemos diferente do que tocamos. Os italianos, pelo contrário, escrevem as suas músicas em verdadeiros valores que tenham concebido para isso. Por exemplo, nós pontuamos [em performance] diversas colcheias que seguem em sucessão por graus, e mesmo assim, as notamos iguais.

Pier Francesco Tosi, Bologna, 1723: Quando, sobre o movimento igual de um baixo que prossegue lentamente de colcheia em colcheia, um cantor vai, quase sempre, por graus com desigualdade do movimento.

Michel de Montéclair, Paris, por volta de 1730: Em [compasso] 2 [binário] simples, a primeira colcheia dura quase tanto tempo como se fosse seguida por um ponto, e a segunda é quase tão rápida quanto uma semicolcheia. Em 3/2, 3, 3/4, ou 6/4, as colcheias são desiguais. Em $2 / 4$ ou $3 / 8$, as colcheias são iguais e as semicolcheias desiguais.

Michel Corrette, Paris, 1741: As colcheias são tocadas igualmente em alguns tipos de música italiana, por exemplo na Courante da Sonata Op.V n⿳07 de Corelli. Porém, na música francesa, a segunda colcheia em cada tempo é tocada mais rápida.

Joachim Quantz, Berlim 1752: É necessário, em peças de velocidade moderada e até mesmo em adagios, que notas rápidas sejam tocadas com uma certa desigualdade, ainda que elas apareçam com mesmo valor, de modo que, a cada número de notas acentuadas, ou seja, a primeira, a terceira, a quinta e a sétima, devem ser mais apoiadas do que as que seguem, ou seja, a segunda, a quarta, a sexta, a oitava etc., embora elas não devam ser sustentadas durante tanto tempo, como se fossem pontuadas.

Através do trabalho de Donington é possível perceber que essa desigualdade de notas, que hoje conhecemos como notes inégales ou inégalité, não era uma prática 
exclusiva do período barroco, e que desde o século XVI já se comentava a respeito. O que ainda não sabemos (e cujo argumento não é encargo deste trabalho) é exatamente a que tipo de desigualdade se referiam os autores dos séculos XVI e XVII.

A pesquisadora Patrícia M. Ranum ${ }^{95}$ adverte que talvez estejamos fazendo um uso errôneo do termo inégalité, englobando neste todos os tipos de desigualdades; pois autores franceses setecentistas, incluindo Hotteterre, utilizavam o termo pointer para designar essa desuniformidade típica da articulação da música francesa. Porém, outras denominações foram dadas por Etienne Loulié, contemporâneo de Hotteterre, em seu Elements ou principes de musique, mis dans un nouvel ordre, publicado em Paris em 1696. Loulié utiliza, além do pointer de Hotteterre, outros termos como lourer e piquer para descrever três níveis de 'alongamento' que as colcheias podem receber ${ }^{96}$.

Os termos louré (ligado, sem ligadura), piqué (picado), détaché (solto, separado) e coulé (ligado, com ligadura), empregados por outros autores franceses, eram utilizados para diferenciar as variações de acordo com o grau da desigualdade. Com isso, pode-se concluir também que a incerteza da utilização do pointer fora da França ${ }^{97}$ seja fruto desse equívoco terminológico, haja vista os comentários acima pertencentes a diferentes autores de outras nacionalidades.

Sendo assim, mesmo que a execução desigual faça parte da tradição italiana pelo menos desde o tempo de Frescobaldi e Puliaschi -, é na música barroca francesa, contudo, que essa prática é coerente e constante. Para confirmar o uso habitual da prática de se executar colcheias pointées, em várias ocasiões podemos encontrar indicações como croches égales, indicando assim a execução 'normal', escrita.

Na música francesa, a dificuldade de aplicar essa desigualdade não está em que local aplicá-la, mas sim na proporção exata. Para executar corretamente o pointer nos instrumentos de sopro, é necessário, antes de tudo, esclarecer a função da articulação nesse assunto.

\footnotetext{
95 "Several decades ago, the pioneers in historical performance practice searched Baroque treatises for facts about musical meter and about rhythmic alteration, that is, the convention we call notes inégales or inégalité but which late seventeenth-century French musicians often called pointer". In: RANUM, Patricia M. Tu-Ru-Tu and Tu-Ru-Tu-Tu: Toward an Understanding of Hotteterre's Tonguing Syllables. The Recorder in the Seventeenth Century: Proceedings of the International Recorder Symposium. Ultrecht: STIMU Foundation for Historical Performance Practice, 1995. p. 217.

${ }^{96}$ Cf. BORREL, E. Les notes inégales dans I'ancienne musique française. Revue de Musicologie, T. 12e, №. 40e. França: Société Française de Musicologie, Nov., 1931. p. 278-279.

97 Para entender que essa ideia de inégalité ainda não é transparente, cf. o artigo de BYRT, John. Some new interpretations of the notes inégales evidence. Early Music (Fev. 2000), e a crítica de David Ponsford e a resposta de Byrt a Ponsford, ambas na revista Early Music edição de Maio de 2000.
} 
Instrumentistas franceses, principalmente os representantes de instrumentos de sopro, como Hotteterre, atribuíam as suas sílabas de articulação à performance das notes inégales. No oitavo capítulo de seu Principes de la Flûte Traversière, Hotteterre explica que para tornar o 'tocar' mais agradável, deve-se variar a articulação (coups de langue) em diferentes maneiras ${ }^{98}$.

A respeito das sílabas de articulação ele diz que

[...] se utilizam duas articulações principais: $\boldsymbol{T u}$ e $\boldsymbol{R} \boldsymbol{u}$. O $\boldsymbol{T} \boldsymbol{u}$ é o mais usado, e serve para quase todas as figuras como as semibreves, mínimas e semínimas, e para uma grande parte das colcheias: porque quando as colcheias estão sobre a mesma linha [nota repetida], ou quando saltam, utiliza-se $\boldsymbol{T u}^{99}[\ldots]$

Ainda sobre a utilização dessas articulações ele explica que

Deve-se observar que o $\boldsymbol{T u}, \boldsymbol{R} \boldsymbol{u}$ é regido pelo número de colcheias. Quando o número é ímpar, se pronuncia $\boldsymbol{T} \boldsymbol{u} \boldsymbol{R} \boldsymbol{u}$ em toda a sequência [...] Quando o número é par, se pronuncia $\boldsymbol{T} \boldsymbol{u}$ sobre as duas primeiras colcheias, em seguida $\boldsymbol{R} \boldsymbol{u}$ alternativamente ${ }^{100}[\ldots]$

Esse procedimento acaba gerando uma desigualdade de notas, pois as notas articuladas com $\boldsymbol{R} \boldsymbol{u}$ tendem a ser um pouco mais longas que as articuladas com $\mathbf{T u}$.

Veja o exemplo dado por Hotteterre ${ }^{101}$ :

98 "Pour rendre le jeu plus agréable, e pour éviter trop d'uniformité dans les coups de Langue, on les varie en plusieurs manières". In: HOTTETERRE, J. M. Op. cit., p. 27.

99 "[...] on se sert de deux articulations principales; Savoir, $\boldsymbol{T} \boldsymbol{u}$ et $\boldsymbol{R} \boldsymbol{u}$. Le $\boldsymbol{T} \boldsymbol{u}$ est le plus en usage, e l'on s'en sert presque par tout; comme sur les Rondes, les Blanches, les Noires, e sur la plus grandes parties des Croches: car lorsque ces dernières sont sur la même ligne, ou qu'elles sautent, on prononce $\mathbf{T u}[\ldots]^{\prime \prime}$ In: Ibid., p. 27.

100 "On doit remarquer que le $\boldsymbol{T} \boldsymbol{u}, \boldsymbol{R} \boldsymbol{u}$, se règlent par le nombre des croches. Quand le nombre est impair, on prononce $\boldsymbol{T} \boldsymbol{u} \boldsymbol{R} \boldsymbol{u}$ tout de suit comme l'on voit au premier exemple. Quand il est pair, on prononce $\boldsymbol{T u}$, sur les deux premières Croches, ensuite $\boldsymbol{R} \boldsymbol{u}$ alternativement, comme I'on vient de le voir dans le deuxième exemple." In: Ibid., p. 28.

101 In: Ibid., p. 27. 


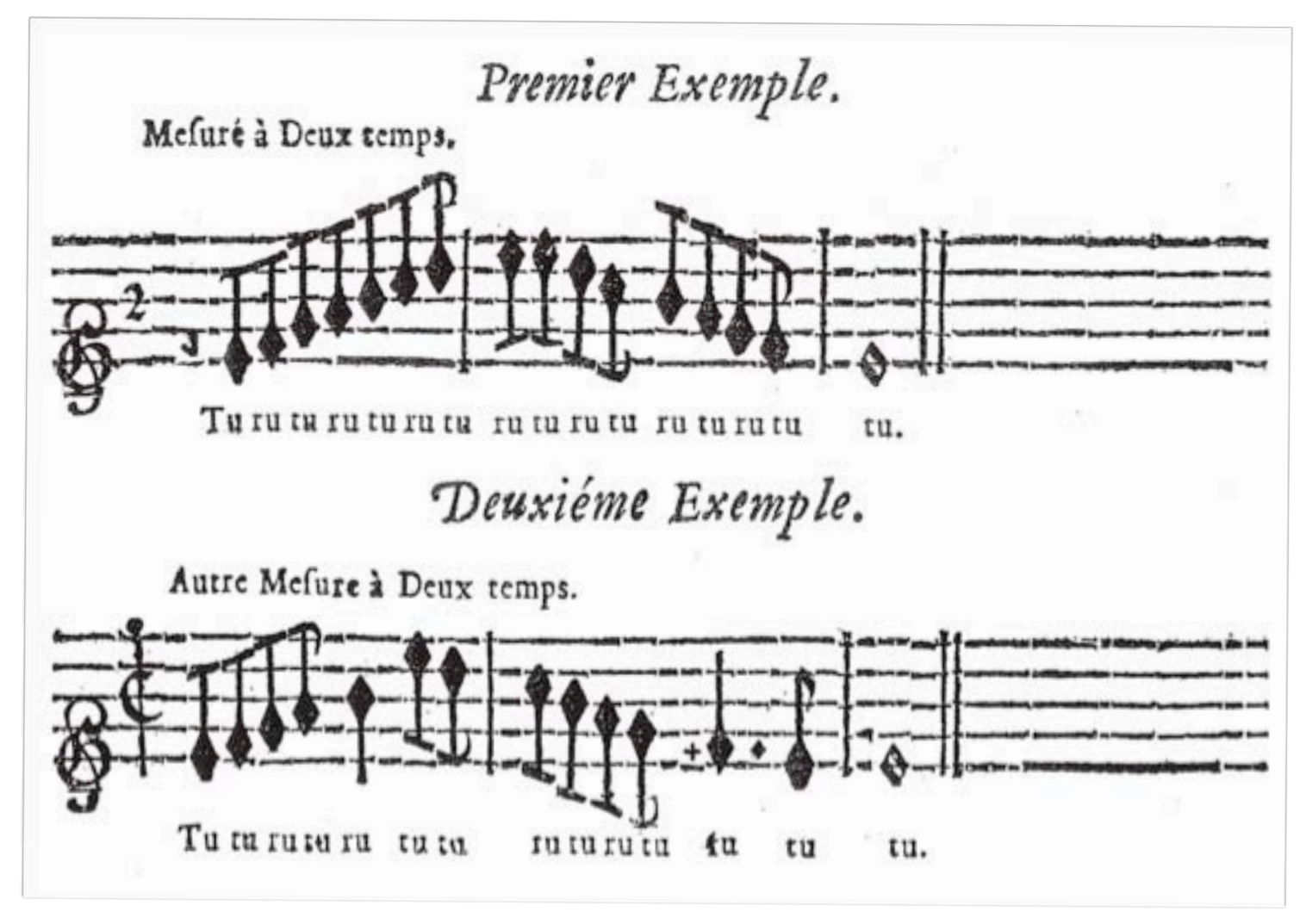

Figura 1.3.: Exemplo de articulação extraído do Princípios da flauta traversa ${ }^{102}$

Relativamente ao uso da articulação para gerar desigualdade rítmica, tão citado por pesquisadores e músicos que estudam o século XVIII, Hotteterre faz a seguinte exposição:

Será bom observar que não se deve tocar as colcheias sempre igualmente, e que se deve, em certas medidas [fórmulas de compasso], fazer uma [das colcheias] longa e a outra curta. Quando [as colcheias] estão em número par, faz-se a primeira longa e a segunda curta, e assim sucessivamente. Quando estão em número ímpar, faz-se tudo [do modo] contrário; isto chama-se pointer ${ }^{103}$.

Hotteterre nos concede também mais informações sobre essa prática da alteração rítmica em seu tratado de flauta traversa, mas é no L'Art de Préluder ${ }^{104}$ que ele faz uma exposição rica em detalhes. Apesar de ter afirmado que essas informações

\footnotetext{
102 HOTTETERRE, J. M. Op. cit., p.27.

103 "On fera bien d'observer que l'on ne doit pas toujours passer les croches également, et qu'on doit dans certaines mesures, en faire une longue e une brève; ce qui se règle aussi par le nombre. Quand il est pair, on fait la première longue, la seconde brève, e ainsi des autres. Quand il est impair, on fait tout le contraire; cela s'appelle Pointer". In: Ibid., p. 28.

104 Ver capítulo 11 da Arte de Preludiar.
} 
não são a 'essência' do prelúdio, Hotteterre nos deixou uma importante contribuição para o estudo não somente dos prelúdios, mas também da interpretação da música instrumental francesa. 


\section{CAPÍTULO 2}

\section{JACQUES MARTIN HOTTETERRE - LE ROMAIN FLÛTE DE LA CHAMBRE DU ROY}

É difícil, se não impossível, desconsiderar a contribuição de Hotteterre para o estudo da história do desenvolvimento dos instrumentos de sopro e, em particular, o da flauta traversa, um dos instrumentos mais em voga na França no início do século XVIII. O próprio Hotteterre atesta sua popularidade, no prefácio de sua primeira obra em 1707: "Como a flauta traversa é um instrumento [musical] dos mais agradáveis e o que está mais na moda, eu acredito que devo empreender este pequeno trabalho, a fim de auxiliar os esforços de todos aqueles que aspiram tocá-la"105.

A importante colaboração de Jacques Martin Hotteterre - Le Romain, o mais ilustre membro da família Hotteterre ${ }^{106}$, torna necessário que se apresente uma biografia do compositor

A música na corte do Rei Luís XIV estava estruturada, do ponto de vista administrativo, em três organizações: Musique de la Chambre (música de câmara), Musique de la Grande Écurie (música da grande cavalariça) e Musique de la Chapelle Royale (música da capela real). Segundo Anthony107, no livro French Baroque Music,

\footnotetext{
105 "Comme la Flûte Traversière est un Instruments des plus agréables, e des plus à la mode, J'ai crû devoir entreprendre ce petit Ouvrage, pour seconder I'inclination de ceux qui aspirent à en jouer." In: HOTTETERRE, J. M. Op. cit.

${ }^{106}$ Cf. HUNT, Edgar. The Recorder and its music. Londres: Herbert Jenkins, 1962.

107 ANTHONY, James. R. Op. cit., p. 19.
} 
submetidos a essas categorias estavam grupos menores, como os Vingt-quatre Violons du Roi ou Grande Bande, os Petits Violons du Roi ou Petite Bande e mais tarde os Violons du Cabinet, embora também tenham sido grupos autônomos devido ao seu grande prestígio.

Benoit realizou um vasto estudo sobre os músicos do Rei ${ }^{108}$, e em seu dicionário sobre a música na França nos séculos XVII e XVIII define Musique de la Chambre como um departamento da música real que reunia os cantores e instrumentistas empregados às manifestações musicais profanas dadas à Corte. Benoit afirma ainda que a origem da Musique de la Chambre remonta a Francisco I (1494-1547) que estabelece a distinção entre os músicos da Câmara, destinados aos seus divertimentos íntimos, e aos da Cavalariça (Musique de la Grande Écurie), encarregados de ilustrar as festas e os desfiles ao ar livre. A Câmara (Musique de la Chambre) compunha-se essencialmente de cantores (em menor número que os da Capela, mas incluindo mulheres), três pages $^{109}$, alaudistas, violinistas, flautistas, cravistas etc. A música da Câmara era produzida em formações diversas de acordo com as necessidades instrumentais e vocais das obras interpretadas: solistas para as audições particulares do soberano; pequenos conjuntos vocais e instrumentais formados por ocasião dos numerosos concertos de appartements ${ }^{110}$ ou para acompanhar as ceias do Rei; grupos mais importantes reunidos para os divertimentos, bailados ou bailes da Corte; enfim, para as grandes obras líricas, primeira orquestra, cujas filas podiam ser aumentadas com músicos da Capela, ou da Cavalariça, ou do Gabinete ${ }^{111}$. A imprecisão dos limites, na

\footnotetext{
108 Ver publicações de Marcelle Benoit, 1971, 1982, 1986, 1989 e 1993.

109 Pages de la Musique du Roi, nome dado, a partir do século XVI, ao grupo de crianças (cantores) pertencentes aos dois departamentos da música real (Musique de la Chambre e Musique de la Chapelle Royale). A utilização destes, provavelmente, foi reduzida com a chegada dos Castrats. Cf. BENOIT, M. Op.cit., p. 522.

110 Divertimento acompanhado de música, de jogo, que o rei oferecia em certos dias nos seus apartamentos a toda corte. A partir da instalação da corte em Versailles (1682), havia "appartement" às segundas-feiras, quartas-feiras e quintas-feiras das $19 \mathrm{~h}$ às $22 \mathrm{~h}$ (bilhar, concertos, danças, mesas de jogo, refeição/lanche). Cf. BENOIT, M. Op.cit., p. 22.

111 O gabinete era sinônimo de um local íntimo da Casa do rei. Para música, refere-se aos músicos pagos pelo tesouro pessoal do rei: aqueles que ensinavam sua arte ao rei ou aqueles que eram convocados pelo rei para a sua recreação particular, por exemplo a Bande des Petits Violons.
} 
prática, entre os diferentes departamentos da música real foi confirmada pelo Édito de $1761^{112}$, decidindo pela sua fusão ${ }^{113}$.

A respeito da Musique de la Grande Écurie, Benoit a conceitua como um departamento da música do rei que agrupava, além dos cavalos de guerra e de equitação com o pessoal unido à sua manutenção, um corpo musical de instrumentistas. Esses oficiais eram divididos sob cinco rubricas, cujas denominações remontam a Francisco I: trompetes, violinos, oboés, sacabuxas e cornetos; oboé e musette de Poitou ${ }^{114}$; flautas e tambores; cromornos e trombas marinas. Três dinastias fizeram nome nesse departamento: os Rodde (trompetes), os Philidor e os Hotteterre (flautas, oboés, fagotes) ${ }^{115}$.

Sobre a Musique de la Chapelle Royale, Benoit afirma que era um departamento da música real que reunia os cantores e instrumentistas tocados de forma afetiva pelo serviço dos ofícios religiosos do rei e da sua corte. A Capela representa a mais antiga das instituições musicais reais e a sua origem remonta aos primeiros Oratórios dos reis merovíngios ${ }^{116}$. Distinguindo-se da Capela-Oratório, que agrupava os eclesiásticos encarregados da liturgia propriamente dita, a Capela compreendia os chapelains, que

\footnotetext{
112 Édito de reunião 1761: Declaração do Rei reunindo em um, os dois departamentos da música real (Musique de la Chapelle Royale e Musique de la Chambre). Cf. BENOIT, M. Op.cit., p. 260.

113 "Département de la musique royale réunissant les chanteurs et les instrumentistes employés aux manifestations musicales profanes données à la Cour. Les origines de la Musique de la Chambre remontent à François I qui établit la distinction entre les musiciens de la Chambre, destinés à ses divertissements intimes, et ceux de l'Écurie, chargés d'illustrer les fêtes et parades de plein air (instruments hauts). La Chambre se composait essentiellement de chanteurs (en moindre nombre qu'à la Chapelle, mais incluant des femmes), de trois pages, de luthistes, violistes, flûtistes, clavecinistes. [...] La Musique de la Chambre se produisait en formations diverses selon les nécessités instrumentales et vocales de œuvres interprétées: solistes pour les auditions particulières du souverain; petites ensembles vocaux et instrumentaux formés à l'occasion des nombreux concerts d'appartements ou pour accompagner les soupers du roi; groupes plus importants réunis pour les divertissements, ballets ou bals donnés à a Cour; enfin, pour les grandes œuvres lyriques, premier orchestre d'envergure, dont les rangs pouvaient être grossis de musiciens de la Chapelle, de l'Écurie, ou du Cabinet. L'imprécision des frontières, dans la pratique, entre les différents départements de la musique royale devait se trouver confirmée par l'Édit de 1761, décidant leur fusion." In: BENOIT, M. Op.cit., p. 124-125.

114 Pequena cornamusa de concepção erudita utilizada na França nos séculos XVII e XVIII, originária de Poitou, província da França, por muito tempo a região do forte dos reis da França. O nome dessa região era dado aos instrumentos de sopro oriundos de Poitou, como os oboés e as musettes, e ao grupo de músicos que utilizavam estes instrumentos na Grande Écurie. É interessante conferir o estudo feito por Bruce Haynes, publicado em 2001, onde o autor menciona o grupo e o oboé de Poitou.

115 "Département de la Musique du Roi regroupant, outre les chevaux de guerre et de manège avec le personnel attaché à leur entretien, un corps musical d'instrumentistes. Ces officiers sont répartis sous 5 rubriques, dont les dénominations remontent à François I: trompettes, violons, hautbois, saqueboutes et cornets; hautbois et musettes de Poitou; fifres et tambours; cromornes et trompettes marines. [...] Trois dynasties ont laissé un nom dans ce département: les Rodde (trompettes), les Philidor et les Hotteterre (flûtes, hautbois, bassons)". In: BENOIT, M. Op.cit., p. 260.

116 Dinastia de reis que governaram grande parte da França e da Bélgica (atuais) dos séculos V a VIII.
} 
participavam da execução do plain-chant ${ }^{117}$ nas grandes missas e cerimônias solenes, e uma proporção crescente de músicos laicos (cantores e instrumentistas) aos quais era confiada a interpretação das composições polifônicas. Graças ao impulso do Rei-Sol, a instituição manteria, até a Revolução, uma tradição de elevada qualidade, reconhecida por Leopold Mozart" ${ }^{118}$.

Os músicos da corte do Rei Luís XIV, que ao fim do seu reinado chegavam a um número entre 150 e 200, estavam subordinados a esses três departamentos, que eram por sua vez relacionados aos locais e serviços musicais, além de cada um deles utilizar instrumentos musicais específicos. Esses músicos eram por diversas vezes, inclusive em documentos oficiais, denominados Musiciens du Roy (músicos do Rei), ou Officiers de la Maison du Roy (oficiais da casa do Rei), ou simplesmente Violon de la Chambre du Roy (violino da câmara do Rei), Hautbois du Roy (oboé do Rei) ou, no caso de Hotteterre, Flûte de la Chambre du Roy (flauta da câmara do Rei).

O livro Les Hotteterre et Les Chédeville ${ }^{119}$, publicado em Paris em 1894, foi de extrema importância para esclarecimentos a respeito dessas importantes famílias de instrumentistas e luthiers. No entanto, as informações sobre a vida de Jacques Martin Hotteterre - Le Romain, mesmo quando combinadas a elementos contemporâneos sobre sua vida e obra, são esparsas e incompletas. A falta de precisão das informações se inicia em relação à data do seu nascimento. A árvore genealógica da família Hotteterre, traçada por Thoinan, estudioso profundo da família Hotteterre, não nos traz a data de nascimento de Jacques Martin Hotteterre, mas somente o ano da sua morte, 1761. Porém, em relação a essa última data também demonstra insegurança, ao afirmar, em seu texto sobre Jacques, dit Le Romain, não ter certeza se teria sido um ano antes, em 1760, ou um ano depois, em 1761.

\footnotetext{
117 Do latim planus cantus, plain-chant foi um termo francês muito utilizado no período barroco; desde o século XIII foi utilizado para distinguir por um lado a música polifônica e medida e, por outro lado, o canto gregoriano tradicional da igreja católica. Cf. BOUISSOU, S. Vocabulaire de la Musique Baroque. Montrouge: Minerve, 1996. p. 166.

118 "Département de la musique royale réunissant les chanteurs et les instrumentistes affectés au service des offices religieux du roi et de sa Cour. La Chapelle représente la plus ancienne des institutions musicales royales, son origine remontant aux premiers Oratoires des Rois Mérovingiens. [...] Distincte de la Chapelle-Oratoire, qui groupe les ecclésiastiques chargés de la liturgie proprement dite, la Chapelle comprend des chapelains, qui participent à l'exécution du plain-chant lors des grand-messes et cérémonies solennelles, et une proportion croissante de musiciens laïcs (chanteurs et instrumentistes) à qui est confiée l'interprétation des compositions polyphoniques. [...] Grâce à l'impulsion du Roi-Soleil, I'institution entretiendra, jusqu'à la Révolution, une tradition de haute qualité, reconnue par Leopold Mozart lui-même". In: BENOIT, M. Op.cit., p. 128.

${ }^{119}$ Cf. THOINAN, Ernest. Les Hotteterre et Les Chédeville. Paris: Edmond Sagot, 1894.
} 
Estudos recentes indicam que ele nasceu em 29 de Setembro de 1674 e morreu em 16 de Julho de 1763, datas que House e Benoit propõem com base na primeira publicação de Hotteterre, em 1707, e no fato de que ele foi citado nos documentos da corte até o ano de $1761^{120}$.

Embora tenha sido titular da função de Hautbois de la Grande Écurie (oboé da grande cavalariça) a partir de 1692, ele era conhecido sobretudo como flautista. Tornou-se Músico oficial da Câmara do Rei (Ordinaire de la Chambre du Roy) em 1717, obtendo o cargo do flautista René Pignon Descoteaux ${ }^{121}$. Além de ter sido oboísta e flautista, Hotteterre tocava também a musette, tradição em sua família. De acordo com Thoinan, Jacques e seu pai Martin foram os mais importantes de sua dinastia $^{122}$.

Sobre o uso do seu epíteto Le Romain, este aparece em sua primeira obra, um tratado de flauta traversa de 1707, quando ele faz referência de si mesmo como Mr. Hotteterre "Le Romain". Thoinan foi o primeiro a sugerir que Hotteterre tenha feito uma viagem para a Itália, com uma prolongada estada em Roma ${ }^{123}$, e Lasocki afirma, baseando-se na pesquisa de Saverio Franchi, que esse fato realmente aconteceu. Franchi encontrou uma referência nos arquivos do Príncipe Francesco Maria Ruspoli, citando o emprego de "Giacomo Hauteterre" como maestro de flauta doce [flauto] de outubro de 1698 a agosto de $1700 .^{124}$

É curiosa a utilização de acréscimos ao seu nome em diversos momentos da sua vida. Na verdade, a utilização do nome de seu avô, de seu pai e de suas viagens em diversos momentos da sua carreira parecia ter o objetivo de melhorar sua reputação e facilitar a sua identificação.

A respeito da primeira modificação no nome Jacques Hotteterre, House menciona que após a morte de Jean (avô de Jacques Hotteterre), Jacques acrescenta

\footnotetext{
120 "The discovery of the date of Jacques' birth has come only within the last decade. Prior to that discovery, scholars generally assumed the year to be later, c.1680. Their assumption was based on the date of Jacques' first publication (1707) and the fact that he was named in court documents up to 1761". In: HOUSE, Delpha LeAnn. Op.cit., p. 31.

121 René Pignon Descoteaux (1645-1728) ocupou os cargos de hautbois et musette de Poitou de 1667-1714 e de ordinaire de la musique de la chambre de 1678-1717. Cf. BENOIT, M. Op.cit., p. 224.

122 Cf. THOINAN, Ernest. Op.cit., p. 37.

${ }^{123}$ Cf. Ibidem., p. 38.

124 "Saverio Franchi turned up a reference in the archives of Prince Ruspoli that he employed "Giacomo Hauteterre" as maestro di flauto ou maestro delli flauti from October 1698 to August 1700". In: LASOCKI, David. The Recorder in print: 2004. American Recorder Magazine, edição de Maio de 2006. U.S.A: American Recorder Society, 2006. p.15.
} 
'Jean' ao seu nome, provavelmente em homenagem ao avô e para registrar publicamente o parentesco com alguém que possuía o título de Musette du Roy (musette do Rei), que provavelmente tinha um lugar na orquestra francesa em 1670, e era conhecido como mestre em fazer instrumentos musicais, possivelmente um dos responsáveis pela modificação interna do corpo dos instrumentos de sopro conhecidos como 'barrocos' ${ }^{\prime 25}$.

Essa relação continua com a junção do nome de seu pai Martin ao seu nome, Jacques-Martin Hotteterre, como comprovado em alguns documentos legais após a morte de Martin em 1712. Martin foi dono de uma longa e brilhante carreira. Seu nome fez parte da lista de instrumentistas que tocaram na apresentação da ópera Xerse, de Francesco Cavalli, apresentada em 1660 na França como parte das comemorações do casamento de Luís XIV126. Com o título de Hautbois e Musette de Poitou, Martin foi o responsável pela adição do segundo pequeno chalumeau à musette. É com essa última variante, somada ao epíteto Le Romain, que Hotteterre completa sua identidade. É como Jacques Martin Hotteterre - Le Romain que ele foi, e continua sendo, reconhecido por diversos autores.

House complementa dizendo que quando Jacques usou o nome de seu avô e de seu pai seguido ao seu próprio em vários momentos após a morte deles, isso pareceu uma questão de um "certo orgulho familiar". Do mesmo modo, o apelido 'Le Romain' seria sobre o que ele também teria orgulho porque viagens fora da França eram algo excepcional para músicos da corte de Luís XIV ${ }^{127}$.

Por ter vivido em uma família abastada que possuía muitas propriedades e pela sua habilidade para escrever, Hottettere, segundo House, certamente tenha tido um alto nível de educação, diferente de outros músicos do seu tempo, que eram apenas alfabetizados $^{128}$.

Sua primeira publicação, segundo House, foi a ária J'ecoûtois autrefois na edição de outubro de 1701 do periódico Recueil d'airs serieux et à boire de differents

\footnotetext{
125 In: HOUSE, Delpha LeAnn. Op.cit., p. 38-39.

126 In: Ibidem., p. 39

127 "When Jacques used the name of his grandfather and father attached to his own at various times after their deaths, it seems a matter of a certain familial pride. Likewise the appellation 'Le Romain' would be on of which he would be proud. Travel outside of France was an exceptional thing for musicians at the court of Louis XIV." In: Ibidem., p. 40-41.

128 In: Ibidem., p. 37.
} 
auteurs, do editor Christophe Ballard ${ }^{129}$. A ária seguinte veio denominada como Air Sérieux de Monsieur Hauteterre le jeune, e como todos os membros da geração sênior de músicos da família Hotteterre tinham quase cinquenta anos de idade ou mais, apenas Jacques e seu irmão caçula Jean poderiam ser considerados Hauteterre le jeune (o jovem). Porém, como as atividades de composição de Jean eram menos ativas do que as do seu irmão mais velho, e como a ária em questão possui uma double ornamentada à maneira italiana ${ }^{130}$ - o que parece confirmar que a publicação sucede o retorno de Jacques à França após quase dois anos na Itália -, é possível considerar essa ária como sendo a primeira publicação de Jacques Martin Hotteterre - Le Romain.

No entanto, é somente após a sua publicação de 1707, considerada a sua primeira obra, Principes de la flûte traversière, ou flûte d'Allemagne, de la flûte à bec, ou flûte douce, et du hautbois, divisez par traitez (Princípios da flauta traversa, ou flauta da Alemanha, da flauta de bico, ou flauta doce, e do oboé, dividido em tratados), que suas atividades foram facilmente registradas. House faz referência ao comentário feito no mesmo ano no periódico Mercure de France, que nessa época chamava-se Le Mercure Galant ${ }^{131}$.

\begin{abstract}
Na página 270 uma 'Air Nouveau' é impressa. [...] O Sr. Hotteterre Le Romain, Ordinaire de la Musique du Roy publica um Livro intitulado, Principes de la flûte traversière, ou flûte d'Allemagne, de la flûte à bec, ou flûte douce, et du hautbois [Princípios da flauta de traversa, ou flauta da Alemanha, do flauta com bocal, ou flauta doce, e do oboél. Este livro deve ser útil aos que se agradam tocar estes instrumentos; haverá demonstrações e explicações sobre todas as dificuldades que poderiam atrapalhá-lo em relação a estes instrumentos, que poderá ter lugar de Mestre os que não teriam condição de ter. Este livro vende-se com o Sr. Christophe Ballard... com o Sr. Foucault..., e com o Autor, na rua Christine. A publicação também foi anunciada no [periódico] Mémoires de Trevoux ${ }^{132}$ : Princípios da flauta pelo Sr. Hotteterre com Ballard: o nome do Autor responde pela
\end{abstract}

\footnotetext{
129 Christophe Ballard pertenceu a uma dinastia de impressores e editores de música, estabelecidos em Paris, que durante quase dois séculos obtiveram o monopólio da impressão musical na França. Cf. BENOIT, M. Op.cit., p. 41.

130 In: Ibidem., p. 41-42.

131 Mercure de France (1724-91) foi o último nome de uma sequência de periódicos que continham informações relativas à música. $\mathrm{O}$ nome do periódico na época da publicação da primeira obra de Hotteterre era Le Mercure Galant (1672-1710). Cf. BENOIT, M. Op.cit., p. 547.

132 Mémoires pour L'Histoire de Sciences e des beaux Arts. Recueillis par l'Ordre de Son Altesse Sérénissime Monseigneur Prince Souverain de Dombes. Trevoux: L'imprimerie de S. A. S., 1707. p. 1487-1488 apud HOUSE, Delpha LeAnn. Op.cit., p. 43.
} 
excelência do Livro. Este hábil intérprete da flauta, não ignora nenhum dos segredos da sua Arte $^{133}$

Esse tratado de Hotteterre foi extremamente popular e utilizado na época. Em 1710 foi publicado em Amsterdam e reimpresso por Ballard em Paris em 1713, 1720, 1721, 1722 e $1741^{134}$. Foi traduzido para o Holandês e publicado por Estienne Roger em Amsterdam em 1728. Somente o tratado de flauta traversa foi traduzido para o Inglês e publicado como The Rudiments or Principles of the German Flute ${ }^{135}$, por Walsh e Hare em Londres em 1729.

Hotteterre e seu trabalho eram conhecidos também na Alemanha. A primeira referência alemã ao tratado (de 1707) parece ter sido a do Das Neu-eröffnetes Orchester de 1713 de Johann Mattheson. Ele escreve que "alguém com o nome Hotteterre, na França, tomou o cuidado de escrever dois ou três pequenos tratados [...] que um amador vai achar que não sejam de grande ajuda"136. A segunda é a de 1732 no seu verbete do Musikalisches Lexicon de Johann Gottfried Walther. Mais tarde, no Musicus autodidactus oder der sich selbst informierende Musicus, de Johann Eisel em 1738; e após essa publicação, Quantz, em 1752, no seu tratado de flauta, menciona Hotteterre como o autor do tratado e também como um famoso instrumentista. Lasocki, no prefácio da sua tradução do Principes de $1968{ }^{137}$, ressalta que é importante

\footnotetext{
133 "On page 270 an 'Air Nouveau' is printed. [...] Mr. Hotteterre le Romain, Ordinaire de la Musique du Roy vient de faire imprimer un Livre intitulé, Principes de la flûte traversière, ou flûte d'Allemagne, de la flûte à bec, ou flûte douce, et du hautbois. Ce livre doit être utile à ceux qui se plaisent à jouer de ces instruments; ils y trouveront des démonstrations e des explications sur toutes les difficultés qui pourraient les embarrasser touchant ces instruments, ce qui pourra tenir lieu de Maistre à ceux qui ne sont pas en état d'en avoir. Ce livre se vend chez le sieur Christophe Ballard ... chez le sieur Foucault ..., e chez I'Auteur, rue Christine. The publication was also announced in the Mémoires de Trevoux: Principes de la flûte par Mr. Hotteterre chez Ballard: le nom de l'Auteur répond de l'excellence du Livre. Cet habile jouer de flûte n'ignore aucun des secrets de son Art". In: HOUSE, Delpha LeAnn. Op.cit., p. 42-43.

${ }^{134}$ Cf. Ibidem., p. 43

135 The Rudiments or Principles of the German Flute. Explaining after an easy Method every thing necessary for a learner thereon, to a greater nicety than has been ever taught before. Wrote in French by the Sr. Hotteterre le Romain; Musician in Ordinary to the late French king, e faithfully translated into English to which is added A Collection of Familiar Airs for Examples. London: Walsh e Hare, 1729.

136 "Es hat sich einer mit Nahmen Hotteterre, in Franckreich die Mühe genommen zwei oder drei kleine Traktaten von der Flûte traversière, von der Flûte à bec, oder Flûte douce u. von dem Hautbois zu schreiben welche einem Liebhaber keine unnütze Handreichung tun mögen". MATTHESON, J. Das Neueröffnetes Orchester. Hamburg, 1713. p. 270-71. Apud HOUSE, Delpha LeAnn. Op.cit., p. 44.

137 HOTTETERRE, J.M. Principles of the flute, recorder e oboe. Trad. David Lasocki. London: Barrie e Rockliff, 1968. p. 14.
} 
perceber que o tratado de Hotteterre era o único livro completo de flauta disponível na Alemanha antes da publicação do tratado de Quantz.

Em 1708, Ballard publica a segunda obra de Hotteterre, Pièces pour la flûte traversière, et autres instruments, avec la basse-continue (Peças para a flauta traversa, e outros instrumentos, com baixo contínuo). Essa obra foi dedicada ao Rei, evidência da importância de Hotteterre para a corte. House explica que tais dedicatórias tinham de ser aceitas pela pessoa a quem se dedica, e normalmente essa honra era reconhecida através de uma doação em dinheiro. Isso é evidente no início da dedicatória, quando Hotteterre indica ter tocado essas peças ao Rei.

Ao $\operatorname{Rei}^{138}$.

Senhor,

A atenção benevolente que Vossa Majestade tem dignado a conceder-me quando tive a honra de tocar estas peças em Sua presença, me inspira agora a ousadia de apresentar-lhes. Que sucesso mais feliz eu poderia desejar-lhes que senão aquele de participar de alguns destes momentos que o maior Rei do mundo quer bem roubar às vezes às suas ocupações gloriosas. É uma vantagem, Senhor, da qual eu estou exclusivamente perante à extrema bondade de Vossa Majestade, e é para expressar-lhe o meu muito humilde reconhecimento, que tomo a liberdade de dedicar-lhe estas peças, me lisonjeando que ele não rejeitará a homenagem, não mais que a reclamação que faço existir em toda minha vida com um zelo muito ardente, e um profundo respeito,

Senhor de Vossa Majestade,

O humilde, obediente e fiel Criado e Súdito

HOTTETERRE

Em 12 de Dezembro de 1711, Hotteterre obtém o privilégio do Rei, o que permite que ele publique diversas obras musicais, tanto vocais quanto instrumentais, para flautas traversas em duas ou mais partes ${ }^{139}$. Esse privilégio expirou em 1723 e, desde então, Hotteterre só voltou a publicar algo em 1737.

\footnotetext{
138 "Au Roy. Sire, L'attention favorable que VOTRE MAJESTÉ a daigné m'accorder lorsque j'ai eu I'honneur de jouer ces Pièces en sa présence, m'inspire aujourd'hui la hardiesse de les lui présenter. Quel succès plus heureux pouvais-je leur souhaiter que celui de remplir quelque uns de ces instants, que le plus grand Roi du monde veut bien dérober quelquefois à ses occupations glorieuses. C'est un avantage, SIRE, dont je suis uniquement redevable à l'extrême bonté de Votre Majesté, e c'est pour lui en marquer ma très humble reconnaissance, que je prends la liberté de lui dédier ces pièces, me flattant qu'elle $n$ 'en rebutera pas I'hommage, non plus que la protestation que je fais d'être toute ma vie avec un zèle très ardent, e un très profond respect, SIRE, de Votre Majesté. Le très humble, très obéissant e très fidele Serviteur e Sujet, HOTTETERRE". In: HOTTETERRE, J. M. Op. cit.

${ }^{139}$ Ver o texto do privilégio na tradução do L'Art de Preluder, neste trabalho.
} 
O ano de 1712 é o período da publicação da sua terceira obra, Sonates en trio pour les flûtes traversières, flûtes à bec, violons, hautbois, etc. (Sonatas em trio para as flautas traversas, flautas doces, violinos e oboés, etc.), dedicada a sua alteza real Monseigneur le Duc d'Orléans, e da sua quarta obra, Première suite de pièces à deux dessus, sans basse continue. Pour les flûtes traversières, flûtes à bec, violes etc., (Primeiro conjunto de peças a duas vozes, sem baixo contínuo. Para as flautas traversas, flautas doces, violas, etc.).

Em 1715, Hotteterre publica a sua quinta obra, Deuxième livre de pièces pour la flûte traversière et autres instruments, avec la basse (Segundo livro de peças para flauta traversa e outros instrumentos, com o baixo). Essa coleção inclui quatro suítes, sendo duas marcadas como suíte-sonatas. No mesmo ano, aparece uma nova edição da sua segunda obra, agora acrescida de vários ornamentos [agréments], e de uma demonstração da maneira com que se deve fazê-los; anexo a este, um baixo adicionado às peças a duas flautas nas páginas 38 e $40^{140}$.

Em 1717, Hotteterre publica o seu Deuxième suite de pièces à deux dessus pour les flûtes traversières, flûtes à bec, violes etc. Avec une basse ajoutée séparément et sans altération des dessus, laquelle on y pourra joindre dans le concert (Segundo conjunto de peças à duas vozes para flautas traversas, flautas doces, violas etc. Com um baixo colocado separadamente e sem alteração das vozes [melodia], o qual poderá ser adicionado para um concerto), como sua sexta obra. Esta foi dedicada ao Monsieur du Fargis, o mordomo do Regente, o Duc d'Orléans, que parece ter sido aluno de Hotteterre, conforme se infere da dedicatória.

Dois anos depois, Hotteterre publica o tratado intitulado L'Art de Préluder sur la flûte traversière, sur la flûte à bec, sur le hautbois, et autres instruments de dessus avec des préludes tous faits sur tous les tons dans différents mouvements et différents caractères, accompagnés de leurs agréments et de plusieurs difficultés propres à exercer et à fortifier, ensemble des principes de modulation et de transposition; en outre une dissertation instructive sur toutes les différentes espèces de mesures, etc. (A Arte de Preludiar para a flauta traversa, para a flauta doce, para o oboé, e outros instrumentos de dessus; com prelúdios compostos em todos os tons, em diferentes movimentos e diferentes caracteres; acompanhados de seus ornamentos e de várias dificuldades

\footnotetext{
140 "gravée sur l'imprimé, et augmentée de plusieurs agréments, et d'une démonstration de la manière qu'ils se doivent faire; ensemble une basse ajoutée aux pièces a deux flutes pages 38 et 40". In: HOTTETERRE, J. M. Op. cit.
} 
apropriadas para praticar e para reforçar. Conjunto dos Princípios de modulação e de transposição; além disso, uma dissertação instrutiva sobre todas as diferentes espécies de compasso, etc.), objeto deste trabalho.

As atividades de publicação de Hotteterre recomeçam em 1721, com o surgimento de um conjunto de transcrições: Sonates à deux dessus par le Sigr. Roberto Valentine, Opera Quinta, accommodées a la flûte traversière par Mr. Hotteterre le Romain [...] Et se peuvent exécuter sur les autres instruments de dessus (Sonatas à duas vozes por Roberto Valentine, Opera Quinta, adaptadas para a flauta traversa pelo senhor Hotteterre le Romain. [...] E podem ser executadas em outros instrumentos solistas) e o conjunto de Airs et brunettes à deux et trois dessus pour les flûtes traversières tirez des meilleurs auteurs, anciens et modernes ensemble les airs de Messiers Lambert, Lully, De Bousset, etc. Les plus convenables à la flûte traversière seule, ornez d'agréments par Mr. Hotteterre le Romain et recueillis par M. +++, (Árias e Brunettes à duas e três vozes para flautas traversas tiradas dos melhores autores; conjunto de árias antigas e modernas dos senhores Lambert, Lully, De Bousset, etc. As mais adequadas para a flauta traversa solo, ornamentadas pelo senhor Hotteterre Le Romain e recolhidas por $M .+++)$. De acordo com House, essas transcrições tinham objetivos didáticos ${ }^{141}$.

Em 1722, surge a sua oitava obra, Troisième suite de pièces à deux dessus pour les flûtes traversières, flûtes à bec, hautbois, e musettes (Terceiro conjunto de peças à duas vozes para flautas traversas, flautas doces, oboés e musettes), e o Pièces pour la musette, qui peuvent aussi se jouer sur la flûte, sur le hautbois, etc. (Peças para a musette, que podem também ser tocadas na flauta no oboé, etc.). Essa seleção de peças foi escrita por seu irmão Jean (Hautbois et Musette du Roy), que falecera em 1720. Essa publicação inclui duas peças para musette compostas por Jacques Martin Hotteterre: Une Suite de Pièces par Accords et La Guerre. (Uma sequência de peças para Paz e para Guerra). Segundo House, essas duas publicações de música para musette foram as primeiras específicas para esse instrumento ${ }^{142}$.

Em 1723, mais dois conjuntos de arranjos de obras de outros compositores foram impressos, com obras de Francesco Torelio e Albinoni: Sonates à deux dessus par le Sigr. Francesco Torelio recueillies et accommodées au gout de la flûte traversière par

\footnotetext{
141 Cf. HOUSE, Delpha LeAnn. Op.cit., p. 63.
}

142 Cf. Ibidem., p. 64. 
Mr. Hotteterre Le Romain. (Sonatas à duas vozes do senhor Francesco Torelio, recolhidas e adaptadas ao gosto da flauta traversa pelo senhor Hotteterre Le Romain). As transcrições das sonatas para violino ${ }^{143}$ de Albinoni feitas por Hotteterre não sobreviveram, bem como a sua nona obra, o Concert du Rossignol (Concerto do Rouxinol), que provavelmente surgiu em 1723. O Concert du Rossignol é citado na décima obra de Hotteterre, Méthode pour la musette (Método para a musette), e também na lista de Obras do Autor no L'Art de Preluder (A Arte de Preludiar), reimpresso em edição fac-similar pela Minkoff, 1978.

Após 1723 não existem evidências de que Hotteterre tenha continuado a compor. No entanto, em 1737, Ballard publica então a décima obra de Hotteterre: Méthode pour la musette, contenant des principes, par le moyen desquels on peut apprendre à jouer de cet instrument, de soi-même au défaut de maître. Avec un nouveau plan pour le toucher, etc. Plus un recueil d'airs, e quelques préludes, dans le tons les plus convenables (Método para a Musette, contendo princípios, através dos quais pode-se aprender a tocar este instrumento, por si só na falta de um mestre. Com um novo plano para tocá-la, etc. Mais uma coleção de músicas, e alguns prelúdios nos tons mais adequados).

As obras de Hotteterre demonstram a sua preocupação com o ensino da performance da música francesa. A Arte de Preludiar, sendo o maior exemplo dessa preocupação de Hotteterre, foi escolhida como objeto deste trabalho. A dedicação ao estudo dessa obra se deu em função da importância que ela representa para a produção artística de Hotteterre e para os flautistas estudiosos da interpretação da música barroca francesa.

Hotteterre teve três filhos com Elisabeth-Geneviève Charpentier. Em 1746 concedeu seu posto de oboísta do Rei ao seu filho Antoine-Jacques Hotteterre, que faleceria um ano depois, em 1747. No mesmo ano, passou o seu cargo de flautista de La Musique de la Chambre du Roy para seu outro filho músico, Jean-Baptiste Hotteterre $^{144}$.

${ }^{143}$ Cf. HOTTETERRE, J.M. Principles of the flute, recorder e oboe. Trad. David Lasocki. p. 16.

${ }^{144}$ Cf. HOUSE, Delpha LeAnn. Op.cit., p. 79-80. 
CAPÍTULO 3

\section{ELEMENTOS FUNDAMENTAIS PARA A COMPREENSÃO DO TRATADO L'ART DE PRELUDER}

Tal como seu título indica, esse tratado foi concebido para ajudar o leitor a aprender a improvisar prelúdios através da prática e do estudo dos exemplos apresentados em seu texto. Esses exemplos utilizam todos os modos e medidas (compassos) comuns no início do século XVIII na França. Além disso, o tratado prevê descrições de cadências, de modulações e como tonalidades e modos são estabelecidos e transpostos. Hotteterre diz que essas descrições são práticas, claras, concisas e ilustradas por exemplos apropriados.

No entanto, talvez a parte do tratado mais utilizada por músicos modernos e estudiosos seja a encontrada na 'instrutiva dissertação' de Hotteterre sobre as várias medidas e suas orientações gerais sobre o valor das notas tocadas "pontuadas, ou seja, desiguais... uma longa e uma curta"145 em cada uma das medidas.

Os exemplos de prelúdios improvisados da prática do L'Art de Preluder fornecem informações valiosas sobre a interpretação da música setecentista. Eles seguem os princípios da improvisação apresentados no tratado e são cuidadosamente concebidos como exemplos pedagógicos. Sobre o estilo de composição de Hotteterre, House afirma que esses prelúdios não tinham qualquer pretensão de serem

145 "pointées, c'est a dire inégales ... une longue et une breve". In: HOTTETERRE, J. M. Op.cit., p.57. 
composições significativas ${ }^{146}$. Porém, sobre a importância dessas composições, Jane Bowers sustenta que os modelos de prelúdio do L'Art de Preluder são os únicos exemplos dessa arte da música francesa para flauta ${ }^{147}$.

Diante de tão importante trabalho, antes de adentrarmos ao texto de Hotteterre é necessário o esclarecimento de termos utilizados pelo autor e, principalmente, a familiarização com elementos musicais do século XVIII que facilitarão a compreensão da sua Arte.

\subsection{Relação Retórica e Música: Musica practica}

A prática musical setecentista estava intimamente ligada ao pensamento do discurso retórico em voga no período barroco. O motivo que levou músicos teóricos e práticos desse período a imergirem na complexa trama de procedimentos, princípios e técnica da retórica consiste em dois fatos.

Em primeiro lugar está o desejo, impulsionado desde o Renascimento, de imitar modelos e estratégias das antigas culturas clássicas. Esse prestígio das culturas grega e latina, que resgatou antigas disciplinas como a poética e a retórica, toma também a música, desde o século XVI, culminando na elaboração de toda uma teoria retóricomusical cujos procedimentos foram registrados em uma série de tratados.

A segunda causa determinante desse processo foi o poder comovente, tal como os bons oradores faziam em seus discursos, uma potencialidade natural da música. Em tal caso, tomar da retórica as ferramentas necessárias para suscitar tais efeitos no ouvinte se tornou uma tarefa fundamental para os músicos setecentistas, e a consequência natural disso foi a edificação de uma completa teorização retórica da música.

Sobre o pensamento musical na era barroca, Manfred Bukofzer comenta que os tratados sobre música barroca podiam ser agrupados de acordo com as chamadas 'disciplinas' da música: musica theorica, musica poetica e musica practica; porém,

\footnotetext{
146 Cf. HOUSE, D. L. Op.cit., p. 179.

147 In: BOWERS, Jane. The French Flute School from 1700-1760. Berkeley: University of Califórnia, 1971. Apud HOUSE, D. L. Op.cit., p. 180.
} 
comete um equívoco no que diz respeito à origem de cada um desses termos, atribuindo suas definições a Aristóteles. Rubén López Cano, em seu texto sobre música e retórica no Barroco, resolve esse problema apresentando a real origem de cada um desses termos; porém, não comenta o engano de Bukofzer ${ }^{148}$.

Os termos musica theorica e a musica practica foram estabelecidos por Boécio no século $V$, e a respeito da sua utilização no Barroco, Lucas explica que

nos escritos musicais (e também matemáticos) publicados nos séculos XVII e XVIII, lemos que a música deve ser concebida como "imitação sonora" das proporções perfeitas da ordem divina. Esses autores seguem a abordagem proposta na Antiguidade e retomada por Boécio, cujo tratado sobre música, escrito no século $V$, teve enorme alcance e, ainda no século XVIII, era compreendido como auctoritas, fonte indubitável de conhecimento ${ }^{149}$.

Já o termo musica poetica só aparece na história com os autores luteranos, impulsionados pelo estudo da Retórica e da Poética de Aristóteles.

A musica theorica se ocupa da especulação teórica, da origem do som, da importância da música para o homem e para o cosmos, e também da Harmonia das Esferas. A musica poetica se ocupa do estudo dos elementos técnicos que estavam à mão do compositor: contraponto, baixo contínuo, modos e metodologia da composição. Já a musica practica se refere aos manuais práticos destinados à execução musical. Neles se ensinavam notação, claves, ornamentação, interpretação vocal e instrumental, técnica instrumental e todos os elementos básicos para os intérpretes.

Enquanto na Alemanha proliferam os tratados dedicados à musica poetica, na França surgem predominantemente obras práticas. Benoit afirma que "na França, não existe a ciência das figuras musicais ou dos repertórios de tópicos como, na mesma época, na Alemanha; nem regras precisas de elaboração do discurso musical"150.

Contrariando o pensamento de Benoit e no caso da obra de Hotteterre, podemos dizer que o pensamento retórico esteve presente na França e principalmente nos

\footnotetext{
148 Cf. BUKOFZER, M. F. Music in the Baroque Era - From Monteverdi to Bach. New York: W.W. Norton Company, 1947. p. 370-371. CANO, Rubén López. Música y Retórica en el Barroco. México: Universidad Nacional Autônoma de México, 2000. p. 38.

149 LUCAS, Mônica. Retórica e Estética na música no século XVIII. Revista ArtCultura, v.9, n.14. Uberlândia: UFU, 2007. p. 225.

150 "En france, il n'existe pas de science des figures musicales ou de répertoires de topiques comme en Alemagne à la même époque, ni de règles précises d'élaboration du discours musical". In: BENOIT, Marcelle. Op.cit., p. 610.
} 
tratados de musica practica, como é o caso do L'Art de Preluder, e essencialmente na construção do texto do manual, como também, em inúmeros elementos musicais.

Para entendermos melhor o L'Art de Preluder, é interessante resgatar a acepção setecentista de termos que compõem o título da obra: o gênero musical prelúdio, objeto do tratado, e o termo arte, que constitui a maneira de abordar essa prática musical.

\subsection{A Arte de Preludiar de Jacques Martin Hotteterre}

a. Arte

A maior parte dos tratados musicais do século XVIII, práticos ou teóricos, fundamentam seu discurso na Retórica e na Poética aristotélicas. No caso do L'Art de Préluder, é possível perceber uma concepção aristotélica do termo arte.

Para Aristóteles, a arte

[...] é idêntica a uma disposição da capacidade de fazer, envolvendo um método verdadeiro de raciocínio. Toda arte se relaciona com a criação, e dedicar-se a uma arte é estudar a maneira de fazer uma coisa que pode existir ou não, e cuja origem está em quem faz, e não na coisa feita $[\ldots]^{151}$

Com isso, podemos perceber que, para Aristóteles, a arte não é fruto de uma inspiração, como esse conceito é concebido a partir do romantismo, mas uma técnica que "envolve um método de raciocínio" e, por isso, segue regras pré-estabelecidas. É com esse pensamento que Hotteterre (1719) desenvolve a sua Arte de Preludiar.

151 ARISTÓTELES. Ética a Nicômacos. Brasília, UnB, 1985, p. 116. 
[...] eu procurarei reduzi-lo [o prélude de caprice] em regras e delas dar os princípios certos e claros, que eu acredito que ninguém o tenha tratado até agora; seja porque havíamos negligenciado este estudo, seja porque o tínhamos julgado ingrato e difícil de tratar. ${ }^{152}$

Freillon-Poncein, em seu tratado La veritable maniere d'apprendre en perfection a joüer du haut-bois, de la flûte et du flageolet, avec les principes de la musique pour la voix et pour toutes sortes d'instrumens, publicado em 1700, já menciona o prélude de caprice, embora não faça uso explícito desse termo. Hotteterre, cerca de vinte anos depois, estabelece um método para tornar a prática do prélude de caprice acessível a todos. Com isso, Hotteterre não é o primeiro a mencionar a prática de se improvisar prelúdios, mas é o primeiro a descrevê-la sistematicamente como uma técnica ensinável.

Antes de investigar no que consiste essa arte de preludiar, é interessante procurar definições setecentistas para o gênero prelúdio.

\section{b. Prelúdio}

O prelúdio, existente na Renascença como um gênero de música para executantes solistas, em estilo improvisatório e não destinado à dança ${ }^{153}$, no Período Barroco, mantém essas mesmas características em composições dedicadas ao alaúde e ao cravo.

Freillon-Poncein e Hotteterre são os responsáveis pela transposição dessa prática para a flauta doce.

[...] algo além de uma disposição para ter o tom do modo que queremos tocar. É feito geralmente de acordo com a força da imaginação dos instrumentistas, ao mesmo tempo que eles [os instrumentistas] querem tocar sem ter escrito antes. ${ }^{154}$

\footnotetext{
152 (...) Je tacherai de le réduire en Règ/es et d'en donner des Principes certains et clairs, ce que personne, a ce que je croie, n'avait entrepris jusqu'ici, soit que l'on ait négligé cette recherche, ou soit qu'on l'ait jugée ingrate, et difficile a traiter. In: HOTTETERRE, J. Martin. Op.cit., p. 1.

153 GROUT \& PALISCA, 2007, p. 264

154 “[...] ce n'est autre chose qu'une disposition pour prendre le ton du mode par où I'on veut jouer. Cela se fait ordinairement suivant la force de l'imagination des joueurs, dans le moment même qu'ils veulent jouer sans les avoir écrit auparavant." In: FREILLON-PONCEIN, J.P. La veritable maniere d'apprendre en perfection a joüer du haut-bois, de la flûte et du flageolet, avec les principes de la musique pour la voix et pour toutes sortes d'instrumens (Paris, 1700). p. 25. Paris: Fuzeau Classique, 2006 (Méthodes e Traités: Flûte à Bec Europe 1500-1800, Volume IV).
} 
O dicionário musical de Sébastien de Brossard, publicado em 1708, ou seja, pouco antes do L'Art de Préluder, nos diz que prelúdio consiste em

uma Symphonie que serve de introdução ou de preparação ao que se segue. Também as Ouvertures das óperas são espécies de prelúdio, como também os Ritournelles que são os começos das cenas etc. Muitas vezes faz-se preludiar os instrumentos de uma orquestra para definir o tom. ${ }^{155}$

O dicionário da língua francesa de Antoine Furetière, de 1690, também descreve o termo. Ele o caracteriza como uma

peça de música irregular que o músico toca antes de mais nada para ver se o instrumento está de acordo, e para se aquecer. Os grandes mestres, frequentemente, compõem prelúdios na hora, que são melhores que as peças estudadas dos outros [compositores]. (vol. III) ${ }^{156}$

Através das definições de Furetière e Brossard é possível constatar que o prelúdio estabelece elementos necessários à prática musical que se seguirá. Retoricamente, essa é a função do exordium, a introdução do discurso (verbal ou musical), a peça que anuncia uma obra mais extensa, como a suíte ou a sonata, ou indica o modo da obra musical a ser apresentada. De acordo com Tarling 157, a finalidade do exordium é preparar a mente do ouvinte para o assunto que se segue. A autora ainda cita Quintiliano, que compara o exordium (do discurso verbal) ao prelúdio tocado na lira antecedendo um debate, o que aproxima ainda mais a função do prelúdio com a do exordium, tornando ambos sinônimos.

O que também atrai nossa atenção é a função prática do prelúdio relacionada à performance. Preludiar serve para definir o tom, ou mesmo para ver se o instrumento

\footnotetext{
155 “Prélude : C'est une Symphonie qui sert d'Introduction ou de Préparation à ce qui suit. Ainsi les Ouvertures des Opéra sont des espèces de Préludes; comme aussi les Ritournelles qui sont au commencement des Scènes, \&c. Souvent on fait préluder tous les Instruments d'un Orchestre pour donner le Ton \&c.". In: BROSSARD, Sébastien de. Op. cit., p. 96.

156 "Prélude: Pièce de musique irrégulière, que le Musicien joue d'abord pour voir si son instrument est d'accord, e pour se mettre en train. Les grands Maîtres composent souvent sur le champ des préludes qui valent mieux que les pièces étudiées des autres".

157 TARLING, Judy. The Weapons of Rhetoric. A guide for musicians and audiences: London: Corda Music, 2004. p.155.
} 
está de acordo ou para se aquecer, demonstrando uma improvisação com um fim prático. No entanto, para Freillon-Poncein e para Furetière, essa improvisação tem função mais ampla: consiste em uma criação que parece ter valor em si, podendo até ser melhor que as peças escritas e estudadas anteriormente à performance.

É interessante notar que Hotteterre não nos fornece uma definição do gênero musical prelúdio, que constitui o objeto de sua arte. Ele já inicia dividindo-os em duas espécies - prélude de caprice e prélude composé, prometendo concentrar-se no segundo.

\begin{abstract}
A palavra prelúdio é suficientemente explicativa, e geralmente conhecida, sem que seja necessária aqui alguma definição. Eu direi somente que a respeito da Música, nós podemos considerar duas diferentes espécies de prelúdios; uma é o prelúdio composto que é comumente a primeira peça daquela que chamamos Suíte ou Sonata, e que verdadeiramente é uma peça entre as formas musicais; desta espécie são também os prelúdios encontrados nas Óperas e nas Cantatas, os quais precedem e anunciam às vezes o que deve ser cantado. E outra espécie é o prelúdio do capricho, que é o verdadeiro prelúdio e que será tratado nesta obra. ${ }^{158}$
\end{abstract}

Hotteterre parece repetir a divisão proposta por Furetière e Brossard: para ele, os prelúdios dividem-se em duas categorias, prelúdios compostos e prelúdios improvisados (que ele denomina prelúdios de capricho). O primeiro refere-se diretamente ao gênero que funciona como introdução de uma obra mais ampla, descrito pelos autores dos dois dicionários. O segundo parece contemplar a asserção de Furetière, de Brossard e de Freillon-Poncein, de que o prelúdio seja um modo de aquecimento e de afinação, e por isso tenha caráter improvisado.

Hotteterre está em conformidade com Brossard e Furetière, afirmando que o prelúdio não tem apenas caráter prático, mas está relacionado à força da imaginação do instrumentista. Ele se estende mais no assunto e se refere à improvisação, ao ato de

\footnotetext{
158 "Le nom de Prélude s'explique assez de lui même, et est assez généralement connu, sans qu'il soit nécessaire d'en donner ici aucune définition. Je dirai seulement qu'en fait de Musique l'on peut considérer deux différentes espèces de Préludes, l'une est le Prélude composé qui est ordinairement la première Pièce de ce que l'on appelle Suite, ou Sonate, et qui véritablement est une Pièce dans les formes; De cette espèce sont aussi les Préludes que I'on place dans les Opéra et dans les Cantates, lesquels précédent et annoncent quelque fois ce qui doit être chanté. L'autre espèce est le Prélude de caprice qui est proprement le véritable Prélude, et c'est dont je traiterai dans cet Ouvrage." In: HOTTETERRE, Op.cit., p. 1.
} 
"brincar com um instrumento". É esse tipo de prelúdio que Hotteterre se dispõe a ensinar em sua arte.

O uso do termo capricho para qualificar o prelúdio improvisado é significativo, e uma investigação mais detalhada desse termo nos traz informações úteis a respeito do objeto do tratado de Hotteterre.

\section{Capricho}

O conceito de capricho faz parte da obra denominada Iconologia, uma importante coleção de emblemas impressa pela primeira vez em 1594 e que circulou amplamente por toda a Europa durante os séculos XVII e XVIII. Nela, Cesare Ripa apresenta os conceitos em forma de imagem e, a seguir, explica-os.

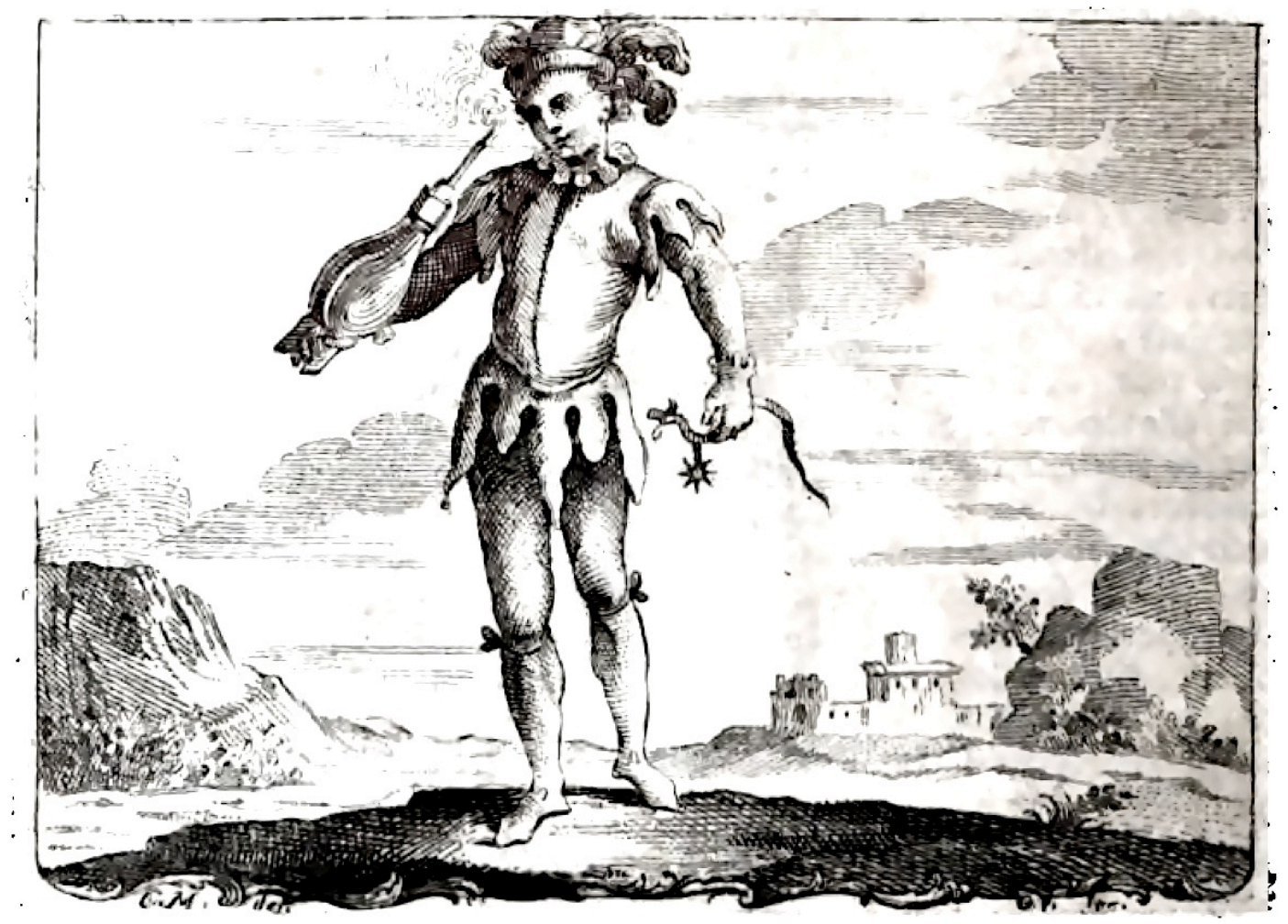

Figura 3.1.: RIPA, Cesare. Emblema 'capriccio' (Iconologia). 1764.

Jovenzinho vestido de várias cores. Na cabeça terá um chapeuzinho semelhante à roupa, sobre o qual estarão penas diversas. Na mão direita terá um fole [usado para reavivar o fogo], e na esquerda uma espora. Caprichosos se diz daqueles, que com ideias diferentes [das] dos outros homens comuns, tomam [escolhem] suas próprias ações, mas com a mobilidade de uma [ação] à outra [mudam de ideia] pelo mesmo gênero [da mesma forma]. Por analogia, se diz capricho [para] as ideias, 
que na pintura, ou na música, ou em outro modo [arte] se manifestam longe do modo comum: a inconstância se demonstra com a infância; a variedade com a diversidade das cores. O chapéu com a diversidade de penas, mostra a diversidade de ações não comuns que é própria da fantasia. A espora, e o fole mostram o caprichoso pronto a adular as virtudes dos outros, ou a ferir os vícios. ${ }^{159}$

Em sua leitura do emblema, Ripa diz que os caprichosos são aqueles homens que possuem um pensamento diferente dos outros homens (homens comuns). E com essa singularidade, estão a tomar as suas próprias ações. Porém ele adverte que, assim como esses caprichosos decidem por uma ação, do mesmo modo, rapidamente, podem decidir por outra ação. Essa descrição de Ripa demonstra a inconstância do capricho, a sua volatilidade.

Ripa também cita especificamente a música. Para ele, capricho em música são ideias incomuns enriquecidas pela variedade com que os caprichosos desenvolvem suas ideias.

É importante ressaltar o uso do fole, instrumento que é utilizado para reavivar o fogo; por analogia, Ripa parece utilizar este instrumento para lembrar do fogo da imaginação do caprichoso, semelhante ao fogo e a força do engenho que Brossard e Furetière se referem ao tratar do termo capricho. Brossard define o termo como

certas peças em que o compositor, sem se submeter a um certo número, ou a uma certa espécie de medida [compasso], ou a algum esboço, dá liberdade ao fogo do seu engenho, o que se nomeia de outra maneira Fantasia, Prelúdio, Ricercata, etc. ${ }^{160}$

O dicionário de Furetière afirma ainda que capricho

\footnotetext{
159 "Giovanetto vestito di vari colori. In capo porterà un Cappelletto simile al vestimento, sopra II quale vi faranno penne diverse. Nella destra mano terrà un Mantice, e nella sinistra uno Sperone. Capricciosi si dimandano quelli, che con idee dalle ordinarie degli altri Uomini diverse, fanno prendere le proprie azioni ma colla mobilità dall'una all'altra pur del medesimo genere, e per modo d'analogia, si dicono capricci le idee, che in pittura, o in musica, o in altro modo si manifestano lontane dal modo ordinario: I'incostanza si dimostra nell'età fanciullesca; le varietà nella diversità dei colori. Il Cappello colla diversità delle penne, mostra che principalmente nella fantasia sono poste queste diversità di azioni non ordinarie. Lo Sperone, ed il Mantice mostrano il Capriccioso pronto all'adulare l'altrui Virtù, o al pungere i vizi." In: RIPA, Cesare. Iconologia. Perugia, 1764. Vol. I, p. 282.

160 "Caprice : Ce sont de certaines pièces, où le Compositeur, sans s'assujettir à un certain nombre, ou une certaine espèce de mesure, ou à aucun dessein prémédité, donne l'essor au feu de son génie, ce qu'on nomme autrement Phantasia, Preludio, Ricercata, \&c.". In: BROSSARD, Sébastien de. Op. cit., p. 17.
} 
[...] se diz também, das peças de poesia, de música e de pintura, que agradam, melhor dizendo, pela força do engenho, do que pela observação das regras da arte, e que não tem um nome certo. [...] [Ver] Os caprices, ou posturas do gravurista Callot ${ }^{161}$.

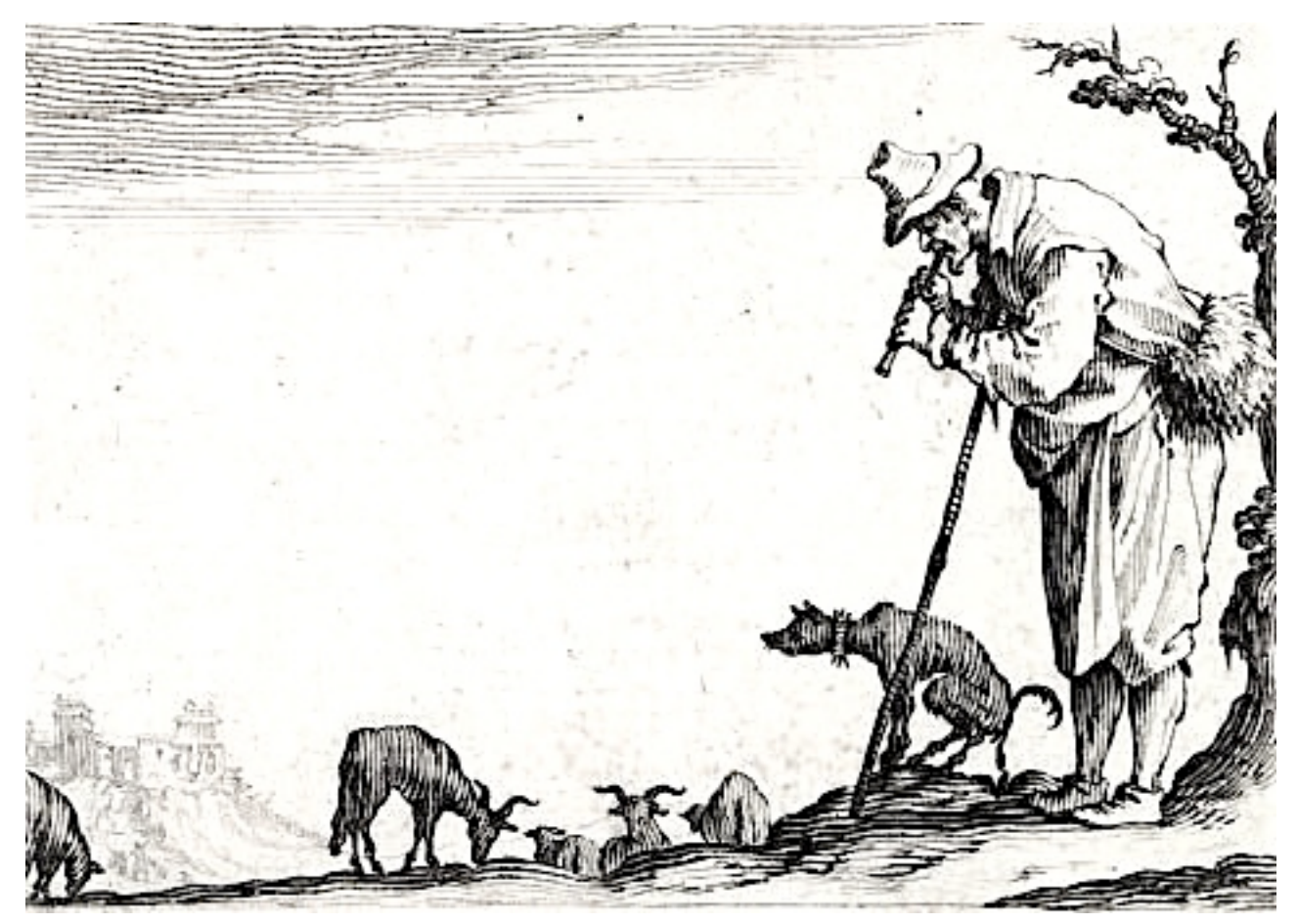

Figura 3.2.: CALLOT, Jacques. O pastor toca a flauta. (Capricci) 1621/1622.

Um dos exemplos dos caprichos de Callot. A postura de um pastor que paralisa o seu trabalho e inicia uma atividade completamente diferente: toca flauta improvisadamente.

De acordo com o emblema de Ripa, com a 'postura' de Callot e com as definições de Brossard e Furetière, podemos perceber então que o capricho está relacionado à fantasia, ou seja, à capacidade de criar pela imaginação, o que nos remete diretamente à ideia de improvisação.

Ripa, Brossard e Furetière concordam também que, no capricho, o engenho se sobrepõe às regras da arte. O termo engenho, que integra as definições de capricho de Brossard e Furetière, é descrito pelo filósofo espanhol Juan Huarte de San Juan, em seu Examen de ingenios para las ciencias, de 1575, como um talento natural ou disposição que se tem para uma coisa mais que para outra. No decorrer da obra, San Juan descreve as diferenças do engenho e o relaciona com as diversas ciências que podem ser aprendidas. Porém, ao explicar sobre uma determinada diferença do engenho, 
dizendo que essa "[...] engloba apenas aqueles engenhos que precisam de mestre e deixa de fora muitos outros cuja fertilidade é tão grande apenas com o objeto e seu entendimento $[\ldots]^{\prime \prime 162}$, ele nos permite dizer que existe engenho que possa ser formado, instruído.

Quando Hotteterre discorre sobre a matéria [canevas] de seus prelúdios de capricho, explica que dará exemplos de prelúdios que usam esses canevas para "começar a se formar o engenho"163. Assim, as duas espécies de engenho descritas por San Juan parecem estar relacionadas com a obra de Hotteterre: o talento natural aliado ao capricho, à improvisação, e aquele relacionado ao ensinamento, à utilidade da obra.

Com isso, é possível perceber que, na Arte de Preludiar de Hotteterre, a escolha do termo prélude de caprice não foi inadvertida. Com essa designação, Hotteterre propõe unir características do prelúdio às do capricho. Ele acopla a improvisação própria do prelúdio à liberdade do engenho típica do capricho. Com isso, torna claros os fundamentos de sua Arte. Esses princípios de Hotteterre parecem ter sido tão claros e importantes para a época que, cerca de quinze anos após a publicação do L'Art de Préluder, Michel Corrette, ao definir o gênero prelúdio em seu Méthode de la flûte traversière, em 1735, contempla apenas o prelúdio improvisado, prélude de caprice, sem mencionar o prelúdio composto: "o prelúdio é uma espécie de capricho que se compõe somente no momento antes de se tocar uma peça"164. Atualmente, Benoit, em seu Dictionnaire de la musique en France aux XVIle et XVIIle siècle, afirma que, a partir do método de Hotteterre, arte de preludiar passa a ser o termo geral para improvisação ${ }^{165}$.

A despeito da predominância do engenho, a disposição natural, é possível notar que Hotteterre considera que o prelúdio de capricho não é fruto apenas da inspiração, como se faria romanticamente supor. Para ele, mesmo a improvisação, o gênero

\footnotetext{
162 [...] abraza solos aquellos ingenios que tienen necesidad de maestro, y deja fuera otros muchos cuya fecundidad es tan grande que con sólo el objeto y su entendimiento [...]. In: SAN JUAN, Juan Huarte de. Examen de ingenios para las ciencias. Baeza, Juan Bautista de Montoya, 1575/1594. Cap. I (1594).

163 "commencer a se former le genie". In: Id. ibid., p. 5.

164 "Le prélude est une espèce de caprice qui se compose ordinairement sur les champs avant que de jouer une pièce." In: CORRETTE, Michel. Méthode de la flûte traversière. Paris, 1735. Amsterdam: U.Frits Knuf Buren, 1978. p. 45.

165 "[...] I'art de preluder est le terme general pour l'improvisation [...]" In: BENOIT, Marcelle. Op.cit., p. 572.
} 
musical menos dependente das regras da arte, está sujeita a leis que possibilitam que ela seja deleitável e que a tornam ensinável.

\section{d. Canevas e Traits}

Em seu tratado, Hotteterre explica que o prelúdio, quando improvisado, não deve ser tocado ao acaso, mas seguindo um plano, ainda que muito simples. Esse plano é a matéria dos prelúdios de Hotteterre, definido por ele como canevas, resultado dos princípios certos e claros que o autor prometeu oferecer em seu tratado.

Para compreendermos o significado desse termo para a época de Hotteterre, iniciamos essa investigação com a acepção de Furetière para caneva.

caneva se diz de uma tela grossa, porém, bastante clara e tecida de modo bastante regular [...] que servirá para serem feitas obras de tapeçaria. [...] Figurativamente, dá-se o nome de canevas às primeiras palavras a partir das quais se compõe uma ária para, em seguida, fazer outras mais regulares. Se diz ainda de um plano de poema, de romance[...] $]^{166}$

Embora Furetière associe o termo caneva à arte da tapeçaria, também é possível imaginar que Hotteterre tenha estabelecido uma relação com o canovaccio $^{167}$ da commedia dell'arte italiana. Nesta, o canovaccio é uma descrição da fase progressiva, implementada através de um tipo especial de escrita (metascrittura, nota), que prescinde da elaboração de um diálogo a ser atribuído aos vários personagens e memorizado pelos intérpretes. Essa explicação faz sentido se lembrarmos que Hotteterre esteve na Itália e absorveu a cultura e o estilo italianos.

166 "Est aussi une toile grosse, mais fort claire e tissue fort régulièrement en petits carreaux [...] pour faire des ouvrages de tapisserie. On appelle figurément canevas, les premières paroles qu'on donne, sur lesquelles on compose un air, pour en faire après de plus régulières. On le dit aussi des mémoires qu'on donne pour écrire quelque ouvrage [...] un plan d'un poème, d'un roman". In: FURETIÈRE, Antoine. Dictionaire Universel: Contenant generalement tous les mots François, tant vieux que modernes, e les termes de toutes les sciences e des arts. La Haye : A. et R. Leers, 1690. http://gallica.bnf.fr/. Acesso em: 19 de Fev 2009.

167 "O canovaccio é, na essência, uma descrição da fase progressiva, implementada através de um tipo especial de escrita (metascrittura, nota), que prescinde da elaboração de um diálogo a ser atribuído aos vários personagens e memorizado pelos intérpretes." "Il canovaccio è, in sostanza, una descrizione progressiva dell'azione scenica, attuata mediante uno speciale tipo di scrittura (metascrittura, appunto), che prescinde dalla redazione di un dialogo da assegnare ai vari personaggi e da mandare a memoria da parte degli interpreti." In: JANSEN, S. Cos'è, nella fattispecie, il canovaccio? Appunti sul "Teatro delle favole rappresentative» di Flaminio Scala. Revue Romane, Bind 25, 1990. http://www.tidsskrift.dk/. Acesso em: 05 de jul 2009. 
Sylvie Bouissou diz que caneva consiste em reutilizar a música de uma dança como apoio em uma forma vocal ${ }^{168}$. Bukofzer acrescenta dizendo que

muitas das músicas instrumentais de dança de Lully não diferem, em estilo, das suas árias; de fato, muitas delas tornaram-se famosas, como as vaudevilles, através da adição do texto, um processo que era chamado de canevas naquele tempo. ${ }^{169}$

Hotteterre fornece exemplos de canevas que serão a base dos prelúdios. Nesse caso, é o plano, a estrutura em que se poderão fazer outros prelúdios, semelhante à estrutura das árias citadas por Furetière, Bouissou e Bukofzer.

A Arte de Preludiar de Hotteterre apresenta dois tipos de canevas, ambos com uma estrutura reduzida ao mínimo indispensável. O primeiro exemplo trata de uma sucessão ascendente e descendente de notas do acorde perfeito da fundamental, com uma extensão de no máximo duas oitavas, terminando com uma cadência final.

I exemplo

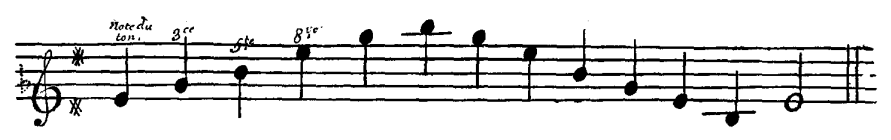

O segundo exemplo é uma sucessão em intervalos de terças, ascendente, partindo da fundamental, com extensão de uma oitava, por vezes seguida de uma semelhante sucessão descendente, terminando em uma cadência final.

II exemplo

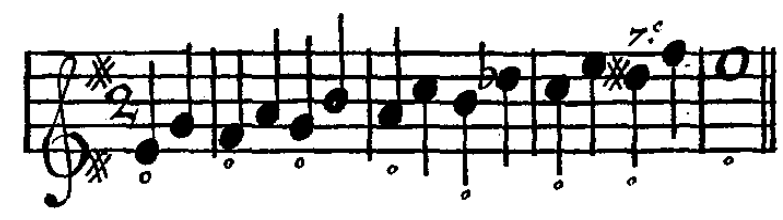

Através desses dois exemplos de canevas, Hotteterre desenvolve variações 'en forme de Trait' que, segundo ele, "poderão servir para dar uma ideia dos princípios do Prelúdio" ${ }^{\prime 170}$.

${ }^{168}$ Cf. BOUISSOU, S. Op.cit., p. 52.

169 "many of Lully's instrumental dance tunes do not differ in style form his airs; in fact, many of them became famous as vaudevilles through the addition of text, a procedure that was called canevas at the time." In: BUKOFZER, M. F. Op.cit., p. 160.

170 In: HOTTETERRE, J. M. Op.cit., p. 5. 
No dicionário de música de Benoit, traits são "ornamentos do canto e dos instrumentos. Sempre tocados destacados, são constituídos por um grupo de notas de curta duração que liga duas notas de uma melodia"171.

Hotteterre utiliza esse termo para os fragmentos, variações dos canevas, que servirão tanto para o estudo quanto para caracterizar 'o gosto' do capricho ${ }^{172}$.

Com referência ao termo gosto [goût] utilizado por Hotteterre, Benoit cita a definição de Racot de Granval, de 1732, que diz que o gosto é o sentimento natural purificado pelas regras ${ }^{173}$. Com essa definição podemos inferir que Hotteterre percebia que a liberdade do capricho era submetida a regras. A qualidade do capricho é apresentada por Hotteterre através da ornamentação, quase uma diminuição italiana (citada anteriormente no primeiro capítulo), ressaltada como fragmentos produzidos quando se brinca com um instrumento. Daí a importância dos traits e de seu estudo para a prática da Arte de Preludiar.

Referindo-se aos traits de Hotteterre, Castellani diz que

De um lado, [os traits] são bastante relevantes para a prática do prelúdio de capricho, contendo ideias e trechos destacados inseridos nos canevas ou planos do prelúdio, mas também autênticos estudos técnicos ligados à eles. Mas por outro lado, existem longas sucessões de arpejos no estilo de Corelli, útil na composição ou na performance das sonatas no estilo italiano, mas bastante inadequados para um prelúdio no estilo francês ${ }^{174}$.

Mais uma vez, a adequação dos elementos italianos na música francesa, presentes na música de Hotteterre, é questionada. Os fragmentos, como os traits, por exemplo, são denominados passaggio por Salvatore em seu artigo sobre a Troisième Suíte de Hotteterre ${ }^{175}$. Assim, o questionamento sobre a utilização de passagens arpejadas na performance da música francesa setecentista gera a hipótese, levantada por alguns autores, de que a música de Hotteterre seja uma expressão do estilo

\footnotetext{
171 "Agrément du chant et des instruments. Toujours joué détaché, Il est constitué d'un groupe de notes brèves et conjointes reliant deux notes d'une mélodie." In: BENOIT, M. Op.cit., p. 685.

172 In: HOTTETERRE, J. M. Op.cit., p. 18.

173 In: BENOIT, M. Op.cit., p. 324.

174 In: HOTTETERRE, J. M. L'Art de Preluder. Florença: S.P.E.S, 1999. Prefácio de CASTELLANI.

175 SALVATORE, D. A proposito della Troisième Suitte di Hotteterre: alcune precisazioni. I quaderni dell'ERTA, n.9, Março, 2006. http://www.ertaitalia.it/. Acesso em: 13 de mar 2009.
} 
italiano. Contudo, é importante procurarmos entender por que a estrutura dos prelúdios de Hotteterre, constituída por canevas e traits, está ligada a essas passagens.

Sobre o termo passagio, ou passage [grafia do século XVIII], Brossard diz que "é uma sequência melódica composta de diversas pequenas notas como as colcheias, semicolcheias, etc., que dura um, dois ou três tempos inteiros ou mais"176. Com isso, podemos considerar que os traits de Hotteterre são de fato semelhantes às passagens mencionadas por Brossard.

Entre os autores que forneceram exemplos desse tipo de ornamentação, Salvatore cita Georg Muffat, pelo importante ensinamento sobre os ornamentos da escola do 'senhor' Lully em seu Florilegium Secundum, publicado em Passau, 1698. Em seu texto, Muffat fornece dez regras para a utilização dos ornamentos. Salvatore aponta que entre essas regras encontramos uma parte específica dizendo que pode ser perigoso arriscar-se a diminuir improvisadamente e, por isso, Muffat dá alguns exemplos das diminuições feitas por Lully ${ }^{177}$.

Com esse exemplo, Salvatore procura nos lembrar que a música considerada referência do estilo francês, a música de Lully, do italiano que chega na França com treze anos de idade, possuía elementos do estilo italiano.

As passagens, oriundas da diminuição italiana de Ganassi desde do século XVI, pertenciam à interpretação de Lully e, consequentemente, estavam presentes no estilo composicional de Hotteterre.

Salvatore infere que talvez estejamos perdendo tempo em discussões como essa, se o estilo composicional de Hotteterre era francês ou italiano, pois Hotteterre era um excelente conhecedor da expressão francesa em função da sua nacionalidade e pela influência da música de Lully em sua formação musical; e da expressão italiana, consequência de suas viagens à Itália e pela sua estreita relação com músicos italianos ${ }^{178}$.

Por fim, toda essa experiência cultural de Hotteterre é revelada em sua obra, e no caso do L'Art de Preluder, na sua matéria, canevas e traits.

\footnotetext{
176 "Passagio, ou passo. Veut dire, Passage. C'est une suite de chant composée de plusieurs petites notes comme Croches, doubles Croches, etc., qui dure une, deux, ou trois mesures tout au plus." In: BROSSARD, S. Op.cit., p. 89.

177 Cf. SALVATORE, D. Op. cit., p.23.

178 Bruce Haynes cita mais uma viagem (Turim-Itália) que Hotteterre teria feito entre 1730 e 1735, sendo o responsável também pela visita dos irmãos Besozzi, músicos italianos, a Paris em 1735. Cf. HAYNES, Bruce. The Eloquent Oboe: A History of the Hautboy from 1640 to 1760. New York: Oxford University Press, 2001. p. 411.
} 
No título do L'Art de Preluder, Hotteterre menciona o fato de ter escrito os seus prelúdios e floreios (traits) "em todos os tons, em diferentes movimentos [mouvements] e em diferentes caracteres [caractères]". Contudo, logo no primeiro capítulo, ele não trabalha somente com o termo tom, mas também com o termo modo, além de outros como cordas, notas etc. Hotteterre diz que "tudo aquilo que se compõe em Música, seja Ária, Symphonie, Cantata, Sonata, etc., pertence a um certo Modo (ou Tom) e deverá terminar absolutamente na nota desse tom"179.

Para compreendermos como é estruturado o pensamento harmônico de Hotteterre, precisamos partir novamente do significado que se tinha naquela época para o termo modo. No verbete mode de Furetière lemos que

em termos de música, diz-se [modo] para as diversas maneiras de cantar ou compor música. O modo é a causa do sistema onde começa cada espécie de oitava, ou a sequência, e o progresso dos seus sete intervalos [escala], porque os modos são alterados segundo a variedade de locais onde se encontram os dois semitons do diapasão [...] cujos tons e consonâncias se vê nas tabelas que foram escritas pelo Pai Mersenne em sua Harmonie Universelle. No cantochão [plein chant] se chamam tons aqueles que em outro lugar são chamados de modos, que vemos por exemplo nas várias tonalidades do Magnificat. ${ }^{180}$

Percebemos que, mesmo para Furetière, existe uma semelhança entre os termos modo e tom. Essa relação é explicada claramente na definição de Brossard citada abaixo:

Modo, ou Tom, quer dizer uma maneira de começar, de continuar, e de terminar uma melodia, comprometendo-se a usar de preferência, e com mais frequência, certos sons ou cordas, do que outros. Existem muitas controvérsias entre autores sobre o nome, a ordem, o número, os efeitos e a natureza dos modos, e mais ainda, sobre a relação dos Antigos

\footnotetext{
179 "tout ce qui se compose en Musique, soit Air, Symphonie, Cantate, Sonate, etc., est dans un certain Mode (ou Ton) et doit finir par la note de ce ton absolument." In: HOTTETERRE, J. M. Op.cit., p. 3.

180 "en termes de Musique, se dit de la diverse manière de chanter, ou de composer les pièces de Musique. Le mode est le lieu du système où commence chaque espèce d'octave, ou la suite, e le progrès de ses sept intervalles; car les modes se changent selon la variété des lieux où se rencontrent les deux demi tons du diapason. [...] dont on voit les tons e consonances dans des tables qu'en à écrites le Père Mersenne en son Harmonie Universelle. Dans le plein chant on appelle tons, ce qu'ailleurs on appelle modes, dont on voit l'exemple dans les divers tons de Magnificat." In: FURETIÈRE, Antoine. Op.cit., v.II.
} 
modos com os Modernos [...] Qualquer modo deve ter três cordas que são chamadas essenciais, como a [corda] Final, a Dominante, e a Mediante. A Final, pode ser uma corda diatônica ou cromática das doze que estão inclusas numa oitava. A Dominante é sempre a nota que é uma quinta justa acima da Final; se ela não é natural, pode-se torná-la justa por acidente, [ou seja], ela deve ser feita por meio de sustenidos ou bemóis que normalmente são colocados imediatamente após a clave sobre o grau dessa dominante. A Mediante, é aquela que divide em duas terças o intervalo que está entre a Dominante e a Final, de fato, também é conhecida como tríade ou trio harmônico. Isso é o que devemos chamar de cordas essenciais do modo. Observe que a terça que está sobre a [nota] Final, pode ser maior ou menor; se ela for maior, ou seja, composta de dois tons inteiros como ut e mi, a chamamos maior ou bequadro. Se esta terça for menor, ou seja, composta de um tom e de um semitom como ré e fá; a chamamos de menor ou bemol. Assim, como só existem duas terças fortes, só existem duas classes de modos; a classe dos modos maiores, e [a classe] dos modos menores. E como sobre os doze Sons, cromáticos ou diatônicos que estão na extensão de uma Oitava, não existe lugar sobre o qual não podemos fazer uma terça maior, seja [ela] natural ou por acidente; existem, portanto, doze modos maiores. E como não existe lugar sobre o qual não podemos fazer o mesmo com uma terça menor, há também doze modos menores[...] Eu teria ainda um infinito número de observações não menos importantes, mas penso que isto é o suficiente para conhecer a forma de pensar sobre os modos segundo a prática de hoje. ${ }^{181}$

Hotteterre parece estar em conformidade com a explicação de Brossard até na utilização de termos como cordas, modo como sinônimo de tom, terça maior, terça menor etc. Contudo, Brossard deixa claro que esse é um campo confuso e que diversos autores discordam em diferentes aspectos do termo.

Sylvie Bouissou define modo de forma muito semelhante a Brossard e acrescenta que fatores como a herança dos modos antigos, a má compreensão dos

181 "Mode, ou Ton. C'est a dire, une manière de commencer, de continuer, e de finir un Chant, qui engage à se servir plutôt e plus souvent de certains Sons ou Cordes, que d'autres. Il y a bien des disputes entre les auteurs sur les Noms, l'Ordre, le Nombre, les Effets e la Nature des Modes, e encore plus sur le rapport des Anciens Modes, avec les Modernes[...]Tout Mode doit avoir trois Cordes qu'on appelle essentielles, savoir, La Finalle, La Dominante, la Médiante. La Finalle peut être quelque Corde que ce soit ou Diatonique ou Chromatique, des douze qui sont comprises dans I'entendue de I'Octave. La Dominante est toujours la note qui est une quinte juste au-dessus de la Finalle, si elle ne l'est pas naturellement, il faut par le moyen des \#\# ou des bb qu'on met d'ordinaire immédiatement après la Clef sur le degré de cette Dominante, la rendre juste accidentellement. La Médiante enfin est celle qui partageant l'intervalle qui est entre la Dominante e la Finalle en deux tierces, en fait aussi ce qu'on appelle la triade ou le trio harmonique. Voilà ce qu'on doit appeler proprement les cordes essentielles d'un Mode. Il faut bien observer que la tierce qui se fait au-dessus de la Finalle, peut-être ou majeure, ou mineure; si elle est majeure, c'est à dire, composée de deux Tons plains comme ut, mi; pour lors le mode est, e on le nomme majeur, ou bécarre: Si cette tierce est mineure, c'est à dire n'est composée que d'un Ton e d'un Semi-ton comme, re, fa; pour lors le Mode est, e on le nomme mineur ou bemol. Ainsi comme il n'y a que deux fortes de tierces, il n'y a en général que deux classes de Modes; la classe des Modes majeurs, e celle des Modes mineurs. Et comme des douze Sons, soit Chromatiques ou Diatoniques qui sont dans l'entendue de l'Octave, il n'y en a point sur lequel on ne puisse faire, soit naturellement, soit accidentellement une tierce majeure, il y a donc douze Modes majeurs: e comme il n'y en a point sur lequel on ne puisse faire de même une tierce mineure, il y a aussi 12 Modes mineurs [...] J'aurais encore une infinité d'observations à faire qui ne sont pas moins importantes, mais je crois que cela suffit pour faire connaître comment il faut raisonner des Modes suivant la pratique d'aujourd'hui." In: BROSSARD, S. Op.cit., p. 61-65. 
tratados e a tonalidade empiricamente utilizada mas ainda não teorizada, são fatores que fizeram uma confusão entre os termos 'modo' e 'tom' durante quase todo o período barroco ${ }^{182}$.

É devido ao Traité de L'Harmonie de Rameau, publicado em Paris em 1722, o registro da sólida diferença dos termos em seu oitavo capítulo do terceiro livro: 'Du Ton, e du Mode'.

Se dermos a terça maior para a nota ut, dizemos que estamos no tom de ut maior, em vez de dizer, no tom de ut, modo maior, da mesma forma, se dermos a terça menor, dizemos que estamos no tom de ut menor $[\ldots]^{183}$

No segundo livro do tratado de harmonia, Rameau confirma que existem apenas dois modos, portanto, um maior e outro menor, assim como Brossard, Hotteterre e outros autores já haviam afirmado. Bouissou menciona que Rameau, seguindo Mattheson, atribui aos modos maior e menor uma afetividade própria. No entanto, em 1690, Marc-Antoine Charpentier já cogitava essa afetividade dos modos em suas Règles de Composition, mesmo que ainda persistisse a confusão das definições de modo e tom. Essa afetividade mencionada por Rameau foi denominada por Charpentier como Énergie des Modes (energia dos modos). Essa carga expressiva dos modos se modificava de acordo com os autores.

Com todas as definições apresentadas, é possível perceber que a terminologia utilizada por Hotteterre para definir os modos de cada prelúdio está também relacionada à expressão das paixões, fortemente influenciada pela energia dos modos de Charpentier.

Especial atenção é dada a seguir para o 'ambiente' que cada prelúdio expressa para Hotteterre. Em seus prelúdios e traits, Hotteterre faz uso de termos que se repetem em diversos exemplos. Por isso, é apresentado a seguir um resumo do significado dessas palavras descritivas que Hotteterre emprega para mostrar o movimento e os

\footnotetext{
182 Cf. BOUISSOU, S. Op.cit., p.128-129.

183 "Si nous donnons la tierce majeure à la note ut, nous disons que nous sommes dans le ton d'ut majeur, au lieu de dire, dans le ton d'ut, mode majeur, et pareillement si nous lui donnons la tierce mineure, nous disons que nous sommes dans le ton d'ut mineur [...]" In: RAMEAU, Jean-Philippe. Traité de L’Harmonie. Paris: Ballard, 1722. Edição fac-similar, Paris: Méridiens Klincksieck, 1986. p. 198.
} 
caracteres de cada modo. Tais significados foram extraídos de dicionários anteriores e posteriores ao L'Art de Preluder. ${ }^{184}$

A respeito do advérbio affectueusement [afetuosamente], o Dictionnaire de I'Académie Française de 1694 o define como "de forma afetuosa". Brossard explica que affetto ou con affetto é o mesmo que affettuoso ou affettuosamente, o que significa, em francês, affectueusement, tendrement, e consequentemente, quase sempre lentement. Brossard transpõe o caráter do termo para a música, afirmando que as obras denominadas affectueusement apresentam um andamento lento, como mais tarde concorda Rousseau, dizendo que affettuoso, quando escrito no início de uma ária, indica um tempo entre o andante e o adagio, e no ambiente [caractère] de uma melodia, uma expressão que é affectueuse e douce.

Sobre o adjetivo animé (animado), Richelet, no final do século XVII, o define como algo para tornar mais vivo, para excitar, para transmitir força, fogo e garra. Furetière apresenta exemplos de movimentos, como o dos pincéis dos pintores quando fazem surgir suas figuras; e também o da dança, quando mestres de dança apresentam na ponta do pé uma ária que é mais viva: 'Venha agora, anime seus passos'. Mais tarde, Brossard expressa conformidade com essas definições e diz que o movimento em música do animé é como o vivace, o allegro, o spiritoso, o brilhante etc., e ainda menciona um outro caráter desse movimento, quando denominado un peu animé, ou seja, um pouco animado.

Sobre o verbo badiner (ironizar, brincar), Richelet afirma que é dizer coisas de uma maneira agradável e refinada: 'brinquem agréablement'. Em conformidade com Richelet, o Dictionnaire de l'Académie Française também menciona um determinado estilo que é agréable, alguns jogos de palavras e pensamentos que podem ser agradáveis. Sempre relacionado ao caráter, a definição do Abbé Roubaud, de 1785, diz que uma mente pode ser badin (brincalhona) quando leva alguém a brincar com coisas verbais. Leveza de espírito, alegria e frivolidade tornam um ser badin, que é o adjetivo derivado de badiner. Uma pessoa séria não é badin. Uma pessoa badin é agradável rindo, é diversificada e fluente em diversões ou jogos. Podemos badiner em qualquer idade, mas existem meios adequados para o fazer. Brincadeira é uma diversão inocente

184 Essas definições podem ser encontradas na pesquisa de Patrícia Ranum em seu site http:// ranumspanat.com/glossary_GtoJ.html. Acesso em: 01 de jul 2009. 
e agradável para a sociedade; a fim de badiner graciosamente, deve-se ser extremamente educado. Não se deve badiner sobre coisas sérias e respeitadas.

A respeito do advérbio fièrement (orgulhosamente), o Dictionnaire de I'Académie Française menciona uma maneira pesada e nobre que é também utilizada para ferocidade e crueldade.

Acerca do adjetivo gai (alegre), Richelet o define como ter alegria, ser alegre, ser jovial. Furetière menciona que alguém que é alegre gosta de júbilo, ou na verdade está cheio de júbilo, ou ainda cria júbilo; e em seguida apresenta o termo em música como "uma ária gai é uma canção alegre". Continuando o pensamento de Furetière, o Dictionnaire de l'Académie Française afirma que, em termos musicais, diz-se do tempo de uma ária correspondente ao allegro italiano. Rousseau amplia o significado em música dizendo que allegro significa gai, e também indica um movimento [tempo] que é próximo ao presto, que é o mais rápido de todos; e alerta que não vai levar muito tempo para se descobrir que este não é apropriado apenas para temas alegres, mas é também aplicável a acessos de fúria, raiva e desespero, os quais não são alegres.

Sobre o advérbio gracieusement (graciosamente, cortesmente), é importante resgatarmos primeiramente as definições de gracieux (gracioso).

Vaugelas, em seu Remarques sur la langue française, publicado em 1647, diz que o significado mais comum é doux, cortês, civil, e na verdade, quando o termo gracieux é usado, ele normalmente é colocado após o termo doux (doux et gracieux, courtois et gracieux), pois assim é mais facilmente aceito. Mais tarde, Corneille diz também que poderia ser dito de uma pessoa que tem envolvimento com diversas habilidades. Brossard menciona que gracieux é sinônimo de soave, gratioso; e diz que gratioso significa uma forma que é agréable, gracieuse, capaz de dar prazer. Contrariando a definição de Brossard, consta no Dicionário de Trevoux, edição de 1771, que gracieux não significa exatamente a mesma coisa que agréable. Gracieux significa alguém que agrada ou quer agradar. É mais do que através de suas maneiras, é através da sua influência que os homens são gracieux. A palavra gracieux não deve ser confundida com de postura civil, educado, gentil. Gracieux e agréable nem sempre se referem às qualidades pessoais; nesse caso, a palavra gracieux manifesta algo que elogia (adula) os sentidos ou a autoestima; e a palavra agréable exprime algo que satisfaça o gosto e o espírito. Portanto, graciosamente (gracieusement), ou de um modo 
que seja gracieux, para Rousseau significava um andante, que caracterizava um ritmo que é marqué (marcado) sem ser gai.

A respeito do adjetivo grave (grave, solene), Furetière afirma que é usado figurativamente para algo majestoso e também com referência ao estilo, acerca do discurso. "O autor chama-se grave quando ele é muito importante, tem grande autoridade no que ele está dizendo".

Sobre o advérbio gravement (gravemente, solenemente), Richelet apresenta como sério, majestoso, com solenidade, e o Dictionnaire de l'Académie Française explica como uma maneira que é grave e com um bom temperamento (composé). Aplicado à música, Rousseau diz que esse advérbio mostra a lentidão do tempo e, além disso, uma certa gravidade na execução. Por comparação, para não deixar dúvidas, o Dicionário de Trevoux menciona que, em música, isso significa um ritmo lento, mas não tão lento como o indicado pela palavra lentement na música francesa; na música italiana, porém, grave é o ritmo mais lento.

Acerca do adjetivo léger (ligeiro, leve, ágil), Furetière explica que bailarinos e acrobatas devem ser légers e relaxados, e que o músico tem uma mão que é léger quando toca instrumentos. Com referência à habilidade de um músico, o Dictionnaire de l'Académie Française diz de um cravista ou organista: "Sua mão é léger". Na edição de 1694 também significa rápido e ágil: "Um pé que é léger".

Sobre o advérbio légèrement (ligeiramente), o Dictionnaire de l'Académie Française define como ligeireza, "de alguma maneira isso é ágil". Brossard menciona que em música légèrement é sinônimo de allegro, leggiadro, brilhante, e vivace. Rousseau, em conformidade com Brossard, diz que essa palavra significa um ritmo ainda mais rápido do que o gai, um ritmo que é meio caminho entre gai e vite (rapidamente). É mais ou menos equivalente ao italiano vivace.

A respeito do advérbio lentement (lentamente, devagar), Brossard diz que lento ou lentamente significa pesadamente, de um modo que seja pesado, lento, preguiçoso, como se estivesse dormindo; e menciona sinônimos como o adagio, o grave, o lento, o languente e o largo. Em conformidade com Brossard, Rousseau diz que essa palavra é o equivalente do italiano largo e indica um ritmo lento. Seu superlativo, très-lentement (muito lentamente), indica o ritmo mais lento de todos.

Acerca do adjetivo lourd (pesado), o Dictionnaire de l'Académie Française o define como pesado, desconfortável para transportar, para mover. Também afirma que 
se diz de certos animais que se deslocam pesadamente, e mesmo dos homens, meio difícil, desconfortável: "A tarefa que é lourd".

Sobre o advérbio lourdement (pesadamente), Richelet define como um modo que seja pesant, inábil, grosseiramente, estupidamente; e o Dictionnaire de l'Académie Française, em conformidade com Richelet, apresenta pesadamente, asperamente: "Ele caiu lourdement".

A respeito do advérbio majestueusement (majestosamente) é importante resgatarmos primeiramente as definições de majestueux (majestoso).

Richelet define majestueux como tendo majestade, com um ar grande e nobre, ganhando respeito e mostrando algo venerável, grave e encantador. Furetière está em conformidade com Richelet com referência ao aspecto de grandeza e menciona os adjetivos nobre, grande, augusto, mostrando grandeza, que atrai respeito e veneração; é especialmente usado sobre a forma, orientação, altura e todo o ' $\mathrm{rr}^{\prime}$ de uma pessoa. Portanto, o termo majestueusement (majestosamente) é definido como algo com majestade, com grandeza, pelo Dictionnaire de l'Académie Française. Em termos musicais, Brossard diz que é sinônimo de grave e majestoso, explicando que majestoso (maestoso) significa uma maneira que é majestueux, cheia de pompa, enfática e, consequentemente, gravement e lentement, embora apareça com expressões como vif e marqué.

Sobre o adjetivo marqué (marcado, acentuado), Richelet explica que é como fazer uma linha sobre o tecido com um pedaço de giz antes de cortá-lo. Furetière diz que se utiliza esse termo quando se tem a necessidade de expressar algo em especial, para indicar alguma coisa, para mostrá-lo em detalhe. "Este pintor cuidadosamente marcou todas as características do rosto". O Dictionnaire de l'Académie Française menciona "para colocar uma marca em algo, para distingui-la de uma outra coisa", e Brossard traduz essa definição em música dizendo que serve para marcar igualmente todas as batidas da medida.

A respeito do adjetivo modéré (moderado), Richelet, sobre o caráter, afirma que é o mesmo que temperado, maduro, sábio, contido, ponderado, regular; e Rousseau, sobre música, afirma que esta palavra indica um movimento (tempo) que é meio caminho entre o lento e o alegre (gai), e que é comparável ao italiano andante.

Sobre o advérbio rondement (circularmente, animadamente, com grande regularidade), Richelet o define como de caráter sincero, franco; e o Dictionnaire de 
I'Académie Française atribui o termo a algo que é uniforme, uniformemente. Furetière, em conformidade com as duas atribuições, explica que essa uniformidade significa "com igual força".

Acerca do adjetivo sautillé (referente a salto, saltitado), o Dictionnaire de I'Académie Française afirma que "para dançar bem, não se deve sautiller". Brossard diz que, na música, há uma espécie de ritmo [movimento] que está continuamente saltando, e quase sempre está em compasso ternário, onde a primeira nota de cada medida é pointée (pontuada). Italianos dizem in saltarello para en sautillant, quando há três semínimas em vez de uma mínima, tal como em 6/4, ou três colcheias ao invés de uma semínima, como em 6/8, especialmente se a primeira nota de cada batimento é pointée. Explica ainda que, por exemplo, são as forlanas venezianas, as sicilianas e as gigas inglesas e outras danças, onde as músicas se movem en sautant.

Sobre o advérbio tendrement (ternamente, carinhosamente), o Dictionnaire de I'Académie Française explica que é o mesmo que "com ternura", e menciona que "pintar tendrement se diz de um pintor que tem um toque leve e delicado". Furetière, em conformidade com esse exemplo, complementa dizendo que "sobre uma pintura ou escultura é dizer ser sensível, ter sensibilidade, ter trabalhado tendrement, o que significa que é feito delicadamente". Rousseau, em termos musicais, diz que esse advérbio escrito no topo de uma ária significa um movimento [tempo] que é lento e doce, e que italianos usam a palavra amoroso para expressar praticamente a mesma coisa.

Sobre o adjetivo vif (animado, vivo), o Dictionnaire de l'Académie Française afirma que também significa ter muito vigor e atividade. A respeito disso, dá o exemplo de que "os olhos de uma pessoa são chamados vif quando são brilhantes e cheios de fogo; ter um espírito que é vif, uma imaginação que é vif, significa ter uma ideia, uma imaginação que pensa de maneira rápida e fácil". Sobre o caráter, diz que um sentimento é vif, paixões são vif, para dizer que alguém é extremamente sensível. Furetière complementa dizendo que significa ardente, veemente, com uma grande quantidade de fogo; picante, tocante, sensível.

Acerca do advérbio vivement (espirituosamente; animadamente), Brossard diz que, em italiano, vivement é o vivace, e complementa afirmando que essa palavra indica um movimento (primeiramente no sentido de "tempo", mas também de 
"emoção") que é gai, rápido e animé, e uma performance que é corajosa e cheia de fogo.

Sobre os termos acima, utilizados por Hotteterre em sua obra, quando apresentadas as suas definições, podemos inferir que a escolha de um adjetivo ou de um advérbio, no início de uma peça, esclarece tanto o caráter da peça quanto o movimento. Essa prática não era somente um hábito de Hotteterre. Couperin afirmava que a música francesa tentava expressar algum estado de espírito definido, indicado por meio de uma palavra como tendrement ou vivement ${ }^{185}$.

Charpentier elaborou uma lista que continha termos que expressavam o caráter e o movimento de cada tom. Segue abaixo a relação desses termos em comparação com os termos utilizados por Hotteterre nos diferentes tons dos prelúdios apresentados na sua Arte de Preludiar.

185 In: DART, Thurston. Interpretação da Música. São Paulo: Martins Fontes, 1990. p. 96. 


\begin{tabular}{|c|c|c|}
\hline Modos & Charpentier (1690) & Hotteterre (1719) \\
\hline C Sol Ut terça maior & Gai et guerrier & $\begin{array}{c}\text { Un peu animé, tendrement, gay, rapidement, } \\
\text { rondement, modéré, }\end{array}$ \\
\hline C Sol Ut terça menor & Obscur et triste & $\begin{array}{c}\text { Lentement, un peu gay, modéré, tendrement, } \\
\text { arpégé, rondement }\end{array}$ \\
\hline C Sol Ut \# & *** & Modéré, rondement \\
\hline C Sol Ut \# terça menor & *** & Tendrement \\
\hline Ré Lá Ré terça maior & Joyeux et très guerrier & $\begin{array}{c}\text { Gravement sans lenteur, gay, fièrement, modéré, } \\
\text { légèrement, vivement, arpégé, lentement, vif, } \\
\text { badinez, }\end{array}$ \\
\hline Ré Lá Ré terça menor & Grave et dévot & $\begin{array}{c}\text { Tendrement, animé, majestueusement, rondement, } \\
\text { marqué, arpégé, lourdement }\end{array}$ \\
\hline E Si Mi bemol terça natural & Cruel et dur & Gravement, gay, gracieusement \\
\hline E Si Mi bemol terça menor & Horrible, affreux & Tendrement, rondement, gay \\
\hline E Si Mi terça maior & Querelleux et criard & Tendrement sans lenteur, gay, rondement, léger \\
\hline E Si Mi terça natural & $\begin{array}{c}\text { Efféminé, amoureux et } \\
\text { plaintif }\end{array}$ & $\begin{array}{c}\text { Modéré, gay, gravement, badinez, sautillé, } \\
\text { rondement }\end{array}$ \\
\hline F Ut Fá terça natural & Furieux et emporté & $\begin{array}{c}\text { Rondement, Un peu animé, modéré, rapidement, } \\
\text { marqué, léger, arpégé }\end{array}$ \\
\hline F Ut Fá terça menor & Obscur et plaintif & Tendrement, gay, gravement \\
\hline F Ut Fá \# terça natural & $* * *$ & Modérément, tendrement, gay \\
\hline G Ré Sol terça maior & Doucement joyeux & $\begin{array}{c}\text { Modéré, gravement, animé, rondement, fièrement, } \\
\text { badinez, arpégé, sautillé }\end{array}$ \\
\hline G Ré Sol terça menor & Sérieux et magnifique & tendrement, gay, affectueusement, sautillé \\
\hline A Mi Lá terça maior & Joyeux et champêtre & Gay, gracieusement, rondement, léger, rapide \\
\hline A Mi Lá terça natural & Tendre et plaintif & $\begin{array}{l}\text { Tendrement sans lenteur, gay, modérément, } \\
\text { gravement, rondement, arpégé }\end{array}$ \\
\hline B Fá Si bemol terça natural & Magnifique et joyeux & $\begin{array}{c}\text { Gay, modérément, arpégé, modéré, rondement, } \\
\text { vivement }\end{array}$ \\
\hline B Fá Si bemol terça menor & Obscur et terrible & Tendrement, gay, gravement \\
\hline B Fá Si terça maior & Dur et plaintif & $\begin{array}{l}\text { Tendrement, gay, gravement, léger, gracieusement, } \\
\text { modéré, animé }\end{array}$ \\
\hline B Fá Si terça natural & $\begin{array}{l}\text { Solitaire et } \\
\text { mélancolique }\end{array}$ & $\begin{array}{c}\text { Tendrement, animé, gay, gracieusement, } \\
\text { rondement, arpégé }\end{array}$ \\
\hline
\end{tabular}

Os adjetivos e advérbios utilizados por Charpentier ${ }^{186}$ influenciaram o caráter e o movimento dos exemplos de prelúdios apresentados por Hotteterre na sua Arte de Preludiar. Hotteterre alterna movimentos rápidos e lentos do começo ao fim dos exemplos e descreve peças mais rápidas como gai.

Quando não se trata de movimentos rápidos (tempo), Hotteterre faz uso de outras palavras para expressar determinados movimentos. No modo C Sol Ut terça maior, o alegre e guerreiro de Charpentier parecem não ter determinado a escolha de Hotteterre. Termos como um pouco animado, ternamente, rapidamente, circularmente (rondement no sentido de com grande regularidade) e moderado foram usados nos prelúdios de tempo moderado.

${ }^{186}$ Disponível em http://www.charpentier.culture.fr/. Acesso em: 01 de jul 2009. 
No modo C Sol Ut terça menor, Hotteterre utiliza os advérbios lentamente, moderadamente e circularmente. É interessante notar que, em um dos exemplos desse modo, Hotteterre utiliza o termo arpégé (arpejado). Esse arpejar poderia estar aliado ao caráter alegre, ou seja, a um modo maior. Porém, como para Charpentier esse modo era obscuro e triste, para Hotteterre essa tristeza também poderia assumir uma regularidade rítmica presente numa sequência de arpejos.

Hotteterre faz uso de três modos não mencionados por Charpentier. C Sol Ut\#, C Sol Ut\# terça menor e F Ut Fá\# terça natural; para Hotteterre, são modos que podem ser ilustrados pelas palavras moderado, ternamente e até gai, em se tratando de movimentos rápidos.

O modo de Ré Lá Ré terça maior, que para Charpentier é feliz e muito guerreiro, para Hotteterre foi traduzido como gravemente sem lentidão, orgulhosamente, vivo e brincalhão, o que demonstra que Hotteterre possa ter traduzido o feliz e muito guerreiro como majestosamente - em conformidade com a definição de Brossard - e por orgulhosamente o aspecto guerreiro, definido como ferocidade e crueldade.

O modo de Ré Lá Ré terça menor é descrito por Charpentier como grave e devoto e, para Hotteterre, é majestoso e pesado; através das definições desses termos, percebemos concordância entre os dois compositores.

Sobre o modo de E Si Mi bemol terça natural, Charpentier o descreve como cruel e duro; porém, Hotteterre utiliza advérbios como gravemente e graciosamente para prelúdios nesse modo.

O modo de E Si Mi bemol terça menor é terno e até gai para Hotteterre, que não partilha da energia horrível e terrível atribuída por Charpentier a esse modo.

No modo de E Si Mi terça maior, Hotteterre usa as palavras ternamente sem lentidão, enquanto Charpentier utiliza os adjetivos briguento e agudo, visões diversas desse modo.

Já para o modo de E Si Mi terça natural, Hotteterre usa as palavras moderadamente, grave, e ainda dois prelúdios apresentados como saltitado ou brincalhão, o que parece estar em conformidade com o pensamento de Charpentier acerca desse modo, expressado por termos como afeminado, apaixonado e queixoso.

No modo de F Ut Fá terça natural, que para Charpentier era furioso e levado, Hotteterre demostra conformidade através do sentido marcado e dos movimentos rapidamente, ligeiro, leve, ágil. 
O modo de F Ut Fá terça menor, Hotteterre apresenta como ternamente e gravemente, o que se aproxima dos termos de Charpentier obscuro e queixoso, através da definição de Rousseau do advérbio ternamente.

Para o modo de G Ré Sol terça maior, que tinha a conotação de docemente feliz, Hotteterre parece ter interpretado como a inocência infantil, de acordo com a leveza da definição do termo badiner do Abbé Roubaud. Assim, Hotteterre expressa esse modo por meio das palavras animado, brincalhão e saltitado.

No modo de G Ré Sol terça menor, Hotteterre usa as palavras ternura, carinho e moderadamente, além de descrever um trait como rápido e outro como saltitado. Em vez da indicação gai, que geralmente é a uma das suas marcas para os prelúdios mais rápidos, o adjetivo moderado é utilizado diversas vezes para os prelúdios nesse modo. Esses estados emocionais fazem sentido com a energia grave e magnífica que Charpentier associa a esse modo.

O modo de A Mi Lá terça maior é representado por Hotteterre pelas palavras alegre, ligeiro, ágil, rápido, em conformidade com a energia feliz e campestre de Charpentier.

O modo de A Mi Lá terça natural, que para Charpentier era terno e queixoso, é empregado por Hotteterre com as expressões ternamente sem lentidão, moderadamente e gravemente. Apenas ternamente e gravemente evocam a ternura do lamurioso ou queixoso que Charpentier associa a esse modo.

No modo de B Fá Si bemol terça natural, Hotteterre usa as palavras moderadamente, animado, circularmente e por duas vezes ele instrui o instrumentista para o arpejado. Esses adjetivos parecem sugerir uma forma animada de magnificência e, no caso dos arpejos, alegria e felicidade que Charpentier previa para esse modo.

O modo de B Fá Si bemol terça menor, traduzido por Charpentier como obscuro e terrível, é apresentado por Hotteterre através dos advérbios ternamente e gravemente, que podem ser considerados, se comparados a definição de Charpentier, apenas como movimento.

O modo de B Fá Si terça maior é apresentado por Hotteterre como ternamente e gravemente, em acordo com o duro e queixoso de Charpentier; porém parece não perder a alegria com alguns exemplos apresentados como ligeiro, ágil e animado.

Já no modo de B Fá Si terça natural, Hotteterre usa as palavras ternamente, animadamente e circularmente, enquanto que para Charpentier é ilustrado por palavras 
como solitário e melancólico. Em suma, esse modo é muito mais animado para ele do que para Charpentier.

As semelhanças e discrepâncias entre a percepção de Charpentier e Hotteterre se tornaram perceptíveis através das definições de cada termo apresentadas anteriormente. Através delas concluímos que estão presentes mais semelhanças do que ideias contrárias. Porém, questões como temperamento e tonalidade também podem ter influenciado a percepção de cada tom para esses compositores.

Durante os últimos anos do século XVII e as primeiras décadas do século XVIII, os músicos franceses não podiam discutir a harmonia de uma peça de música da maneira como fazemos no século XX. Fontes históricas sugerem que a circulação de um modo para outro foi guiada tanto pela função poética da música quanto pelas considerações tonais ou do contraponto. Enquanto a harmonia tonal foi sendo codificada, muitos sérios 'amadores' aparentemente tentavam absorver as novas informações. Por exemplo, para identificar rapidamente um modo, eles simplesmente olhavam para a nota final da peça. Essa prática foi tão difundida que o flautista Hotteterre repreendeu seus contemporâneos por recorrer a uma prática tão infantil quando poderiam aprofundar sua compreensão nos recentes avanços da teoria musical.

Dir-me-ão talvez que, sem se dar tanto trabalho para conhecer um modo de uma peça, se deve olhar a nota final e se descobrirá de uma só vez: Concordo com isso, embora existam algumas exceções a esta regra; mas responderei que na totalidade das pessoas que se aplicam às ciências, existem as que se contentam em tocar a superfície [dos conteúdos], e outras que sentem que nunca poderão se aprofundar bastante; ora, é para estes últimos que escrevi isto e não para os outros ${ }^{187}$.

Para os amadores, que desejavam ter uma investigação um pouco mais científica, porém sem se aprofundar nas regras de uma verdadeira modulação estabelecida no seu manual, Hotteterre ofereceu a seguinte dica: procure por sustenidos ocorrentes, porque eles são o principal sinal do modo. Na ausência de

\footnotetext{
187 "On me dira peut-être que sans se donner tant de peine pour connaître le mode d'une pièce, l'on n'a qu'a regarder la note finale et qu'on le verra tout d'un coup: je conviens de cela, quoi que cette règle ne soit pourtant pas sans quelque exception; mais je répondrai que dans le nombre des personnes qui s'appliquent aux sciences il y en a qui se contentent d'en effleurer la superficie, et d'autres qui ne peuvent a leur gré assez les approfondir; Or c'est pour ces derniers que j'ay écrit ceci et non pour les autres." In: HOTTETERRE, J. M. Op.cit., p. 50.
} 
acidentes ocorrentes, os leitores vão, ele admite, ter de aprender automaticamente quais modos são associados a que bemóis ou sustenidos nas armaduras de claves.

Sustenidos e bemóis na armadura de clave, ou como acidentes, fornecem pistas a mais do que o reconhecimento do modo. Eles permitem aos músicos a dedução da atmosfera geral esperada em relação a estes modos. Patricia Ranum, em seu livro The Harmonic Orator, cita exemplos dessa prática.

Por exemplo, músicos sabem que bemóis na armadura de clave indicam uma energia gentil, um ambiente introspectivo, enquanto sustenidos transmitem sentimentos de partida de maneira mais afirmativa. Quanto mais bemóis ou sustenidos na armadura de clave, mais forte será a paixão expressada pela ária ${ }^{188}$.

O ambiente geral de um modo com uma tríade maior é muito diferente do ambiente de um modo que possui uma tríade menor. O primeiro é alegre, animado, e o último triste. Dentro dessas duas categorias, o grau de alegria ou tristeza é sugerido pelo número de sustenidos ou bemóis na armadura de clave; alguns desses modos apresentavam os acidentes como ocorrentes durante todo o período barroco. Embora Hotteterre tenha ilustrado cada armadura e escala para seus leitores do L'Art de Preluder e lhes dado exemplos de prelúdios em cada modo, os modos mais extremos são raramente ou nunca utilizados.

É por todas essas informações apresentadas, componentes da Arte de Preludiar, que o trabalho didático de Hotteterre é extremamente importante. Não é somente um conjunto de exemplos de prelúdios e ornamentação, mas uma fonte de elementos que compõem toda a música francesa instrumental setecentista.

\footnotetext{
188 "For example, musicians knew that flats in the Key signature indicate a gentle, introspective ambiance, while sharps convey more assertive, outgoing sentiments. The more flats or sharps in the key signature, the stronger the passions expressed by the air". In: RANUM, P. The harmonic orator: the phrasing and rhetoric of the melody in French baroque airs. New York: Pendragon Press, 2001, p.336.
} 

CAPÍTULO 4 A ARTE DE PRELUDIAR:

TRADUÇÃO COMENTADA DO TRATADO

L'ART DE PRELUDER (1719)

JACQUES MARTIN HOTTETERRE - LE ROMAIN 


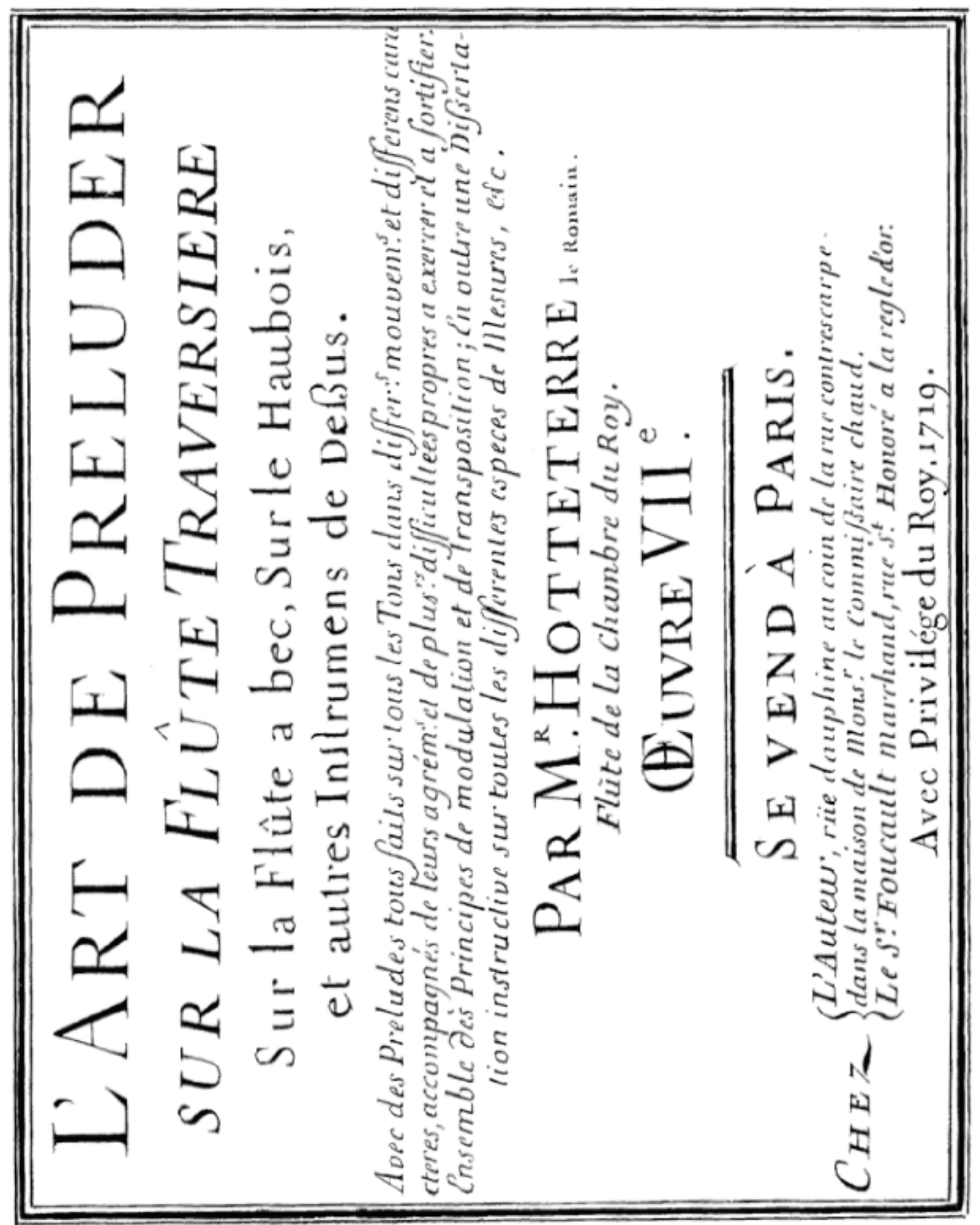




\section{A Arte de Preludiar}

Para a flauta traversa ${ }^{189}$, para a flauta doce, para o oboé e outros
instrumentos de dessus ${ }^{190}$.

Com prelúdios compostos em todos os tons, em diferentes movimentos e diferentes caracteres; acompanhados de seus ornamentos e de várias dificuldades apropriadas para praticar e para reforçar. Conjunto dos Princípios de modulação e de transposição; além disso, uma dissertação instrutiva sobre todas as diferentes espécies de compasso, etc.

\section{Pelo senhor Hotteterre le Romain.}

Flautista da Câmara do Rei.

\section{Obra}

\section{Vendas em Paris}

Com o autor, rua Dauphine à esquina da rua Contrescarpe.

$\mathrm{Na}$ casa do senhor Commissaire Chaud.

[Com o vendedor] Sr. Foucault, a La regle d'or, rue St. Honoré

Com o privilégio ${ }^{191}$ do Rei. 1719

\footnotetext{
189 Será utilizado o termo flauta traversa seguindo a terminologia utilizada pelos portugueses no século XVIII. Cf. ANDRADE, Alexandre. A Presença da Flauta Traversa em Portugal de 1750 a 1850. Portugal: Universidade de Aveiro, 2005. http://www.meloteca.com/tese-flauta-traversa-alexandre-andrade.htm. Acesso em: 10 de mar 2008.

$190 \mathrm{O}$ termo dessus, que se refere a um registro vocal ou instrumental, e também a parte superior de uma peça musical, pode ser substituído pelo termo instrumento melódico numa tentativa de indicar outros instrumentos musicais que possam fazer uso deste tratado. "Parte superior de uma peça de música, aquela que reina acima de todas as outras." In: ROUSSEAU apud BENOIT, M. Op. cit., p. 230.

191 Informações sobre o privilégio concedido a Hotteterre são encontradas no segundo capítulo deste trabalho.
} 
ริง ช.ำ 3.

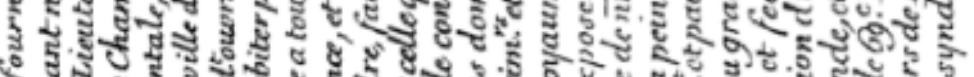
8 马ी 0 สั้

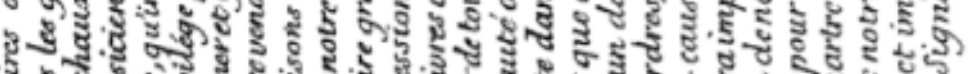

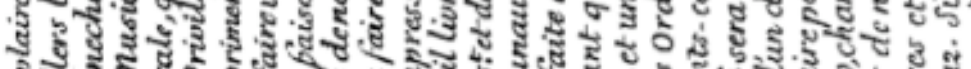
5.

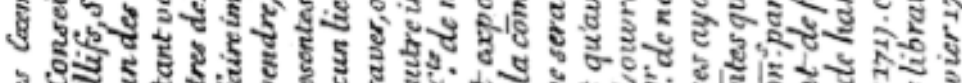
3. उี

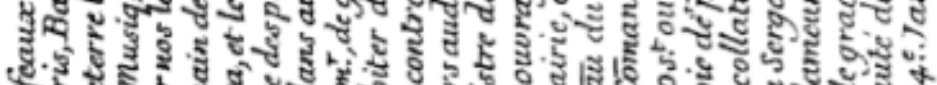

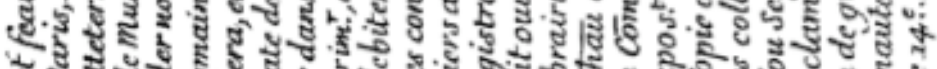
ชั

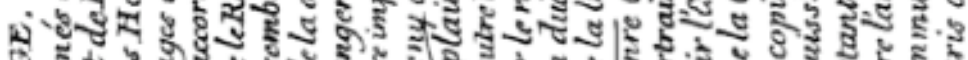
ब

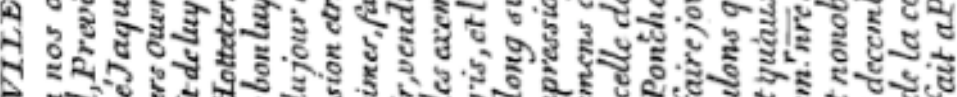
4.

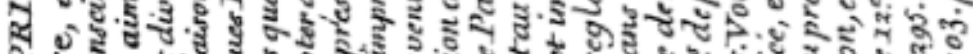

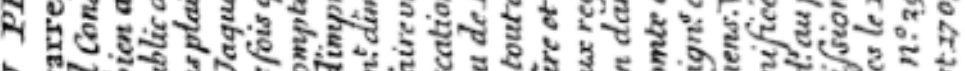
1 ,

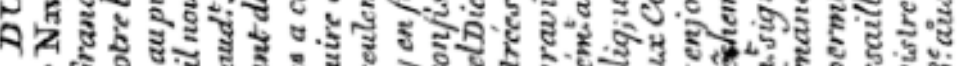
月,5

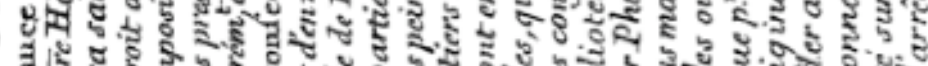

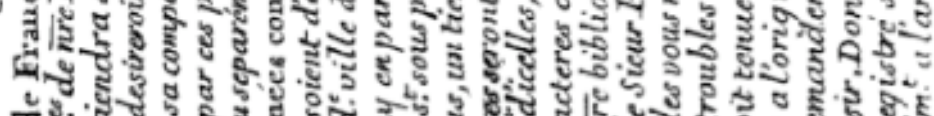

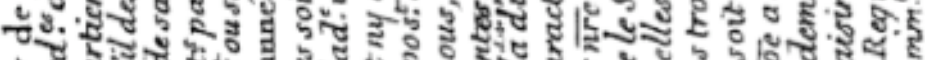
万ิ5 A 5 क

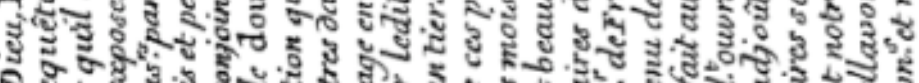
ดु ช้. 2.

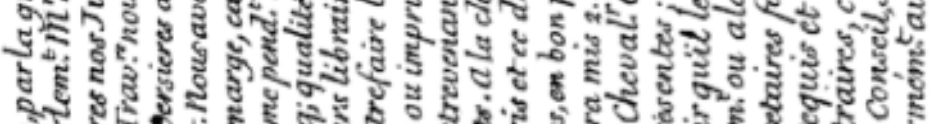
की

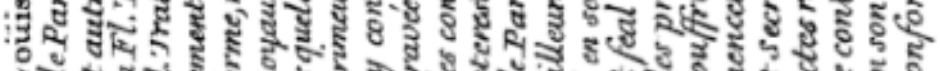
เป็ ปี่

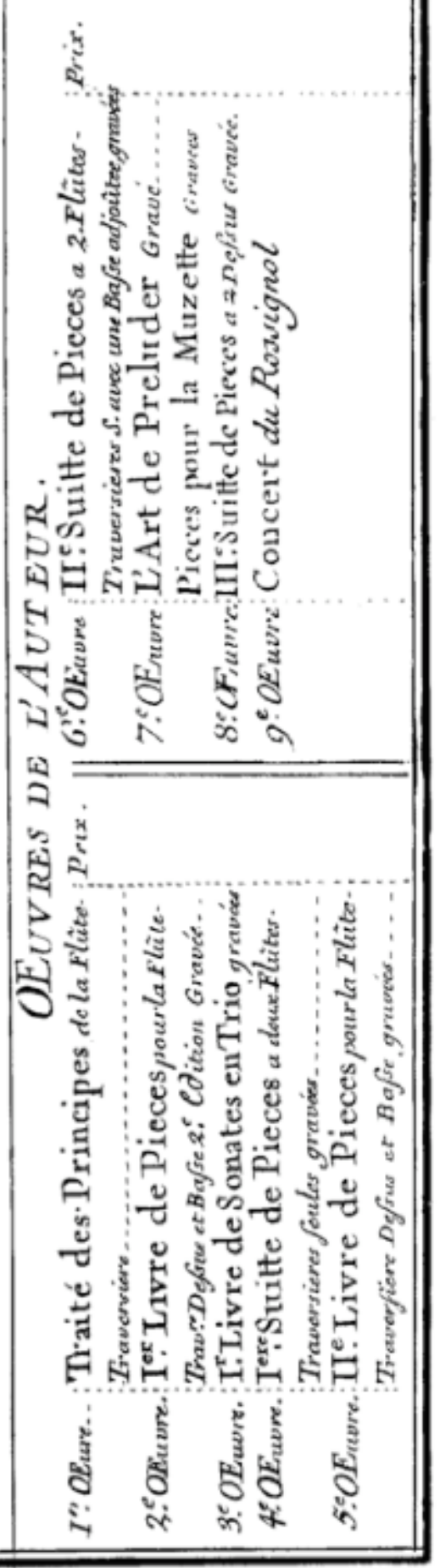




\section{Cópia do Privilégio Os exemplares foram fornecidos}

Luís, pela graça de Deus, Rei da França e de Navarra; nossos amados e fiéis conselheiros, advogados que ocupam o parlamento, mestres de petições de nossa administração municipal, grande conselho, o gestor, oficial principal de Paris, os magistrados, os senescais, os seus tenentes civis, e nossos outros amantes da justiça a quem ele reconhece o cargo. Nosso querido Jacques Hotteterre, um dos músicos de nossa câmara para [i.e. executante de] a flauta traversa, nos expôs que desejava dar ao público diversas obras de música, tanto vocal quanto instrumental, para duas flautas traversas ou mais partes em sua composição, e se nos agradava dar-lhe nossas cartas de privilégio apenas para a cidade de Paris. Nós permitimos [passado] e permitimos [ainda, presente], diante dos auditores presentes, Jacques Hotteterre - Le Romain, de imprimir e registrar a referida obra na forma, margem, caractere permitida, em conjunto ou separadamente e quantas vezes for necessário; e de vendê-la, permitir a venda e distribuir por todo o nosso Reino durante o tempo de doze anos consecutivos a contar do dia da data deste documento. Proibimos todas as pessoas, quaisquer que sejam sua qualidade e condição, de introduzir uma impressão estrangeira em algum lugar de nosso domínio, e a todos os impressores livreiros e outros na referida cidade de Paris, de imprimir, encomendar a impressão, de registrar ou solicitar o registro, vender, ou permitir a venda, nem falsificar a referida obra totalmente ou em parte, e dela fazer vir, vender nem distribuir outra impressão que não seja aquela que será gravada ou impressa pelos referidos expositores oficiais sob pena de confiscação dos exemplares falsificados [no valor de] mil libras de multa [para] cada um dos contraventores, das quais um terço [será] para nós, um terço para o hospital público de Paris, e outro terço para o expositor por todas as despesas decorrentes por danos e indenizações. Assim que essas presentes [cartas de privilégio] forem registradas completamente no registro da comunidade dos impressores e livreiros de Paris, três meses depois deste registro é que a gravação e impressão da dita obra será feita no nosso Reino e não fora dele em bom papel e em bons caracteres conforme as regras da livraria; e que antes de os expor [exemplares] à venda, dois deles serão colocados em nossa biblioteca pública, um naquela do nosso castelo do Louvre e um naquela do nosso muito querido e fiel cavalheiro chanceler da França o senhor Phelipeaux conde de Pontchartrain comandante das nossas ordens, e tudo isso sob pena da nulidade das presentes [cartas de privilégio], que manda e ordena o expositor e seus representantes gozarem plenamente e pacificamente de seu conteúdo, sem sofrer quaisquer perturbações e impedimentos que sejam. Queremos que a cópia deste privilégio, que será impressa ou gravada no começo ou no fim da dita obra, seja prudentemente marcada, e que as cópias subordinadas, por um dos nossos amados e fiéis conselheiros e secretários seja anexada à original. Pedimos ao primeiro de nossos guardiões ${ }^{192}$ ou sargentos de fazer a execução de todos os atos requeridos e necessários sem pedir outra permissão, e não obstante clamações públicas condenantes ${ }^{193}$, e cartas em contrário, uma vez que tal é nosso poder. Acontecido em Versalhes no dia 12 de dezembro no ano de graça de 1717 e do nosso reino o [ano] 69 e pelo rei e seu conselho, assinado Bellavoine. Sob o registro $\mathrm{n}^{\circ} 295$ da comunidade dos livreiros e impressores de Paris p. 297 conforme os regimentos e notavelmente ao decreto de 13 de agosto de 1703. Feito em Paris em 14 de Janeiro 1712. Assinado Josse, síndico ${ }^{194}$.

\footnotetext{
192 O termo huissier foi traduzido como guardião. Furetière o define como oficial que guarda a porta da casa do Rei. Cf. FURETIÈRE, Antoine. Op. cit., vol. II.

193 Haro, traduzido no texto acima como clamações públicas condenantes, era um termo do Costume da Normandia. Furetière explica que era um grito que se fazia na Normandia, na hora em que se encontrava a sua vez e que alguém queria se posicionar frente ao juiz. Cf. FURETIÈRE, A. Op. cit., vol. II.

194 Oficial que é encarregado dos serviços de uma cidade, de uma comunidade. Antigo magistrado ou procurador de cortes, comunidades etc. Cf. FURETIÈRE, Antoine. Op. cit., vol. III, e Dicionário Eletrônico HOUAISS da Língua Portuguesa. Rio de Janeiro: Ed. Objetiva, 2001.
} 


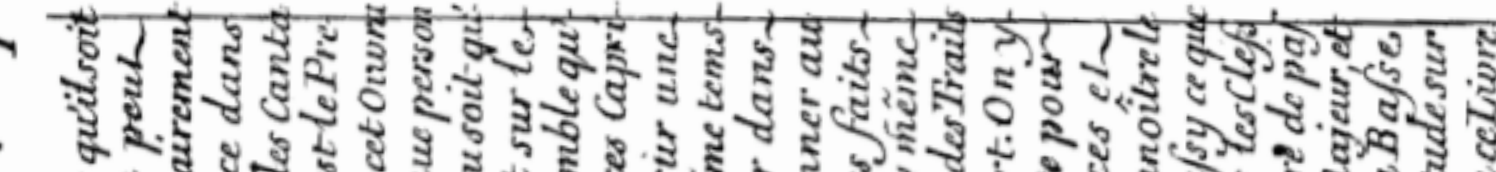

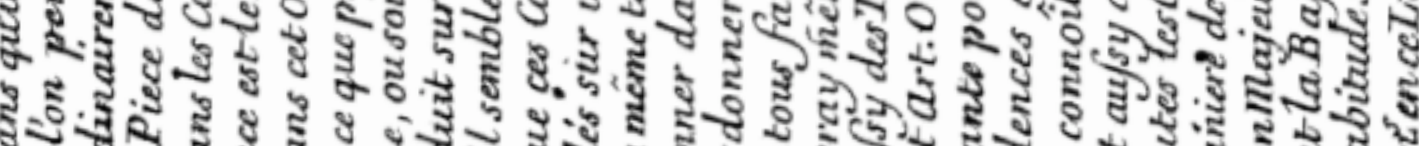

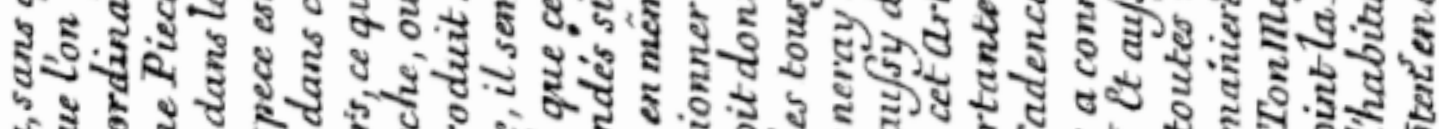

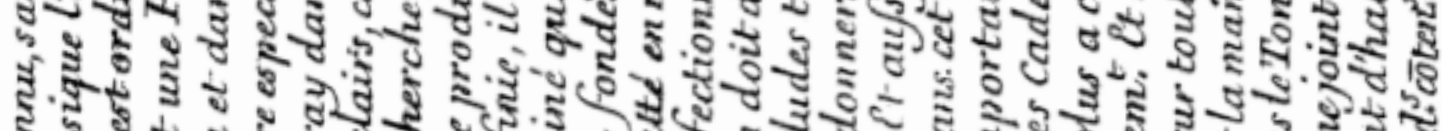

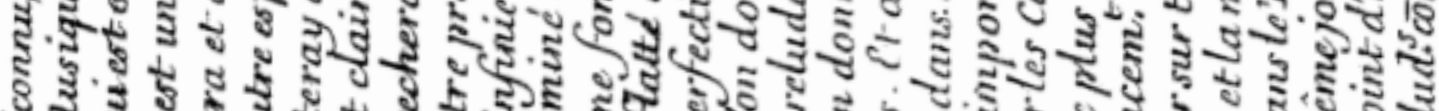

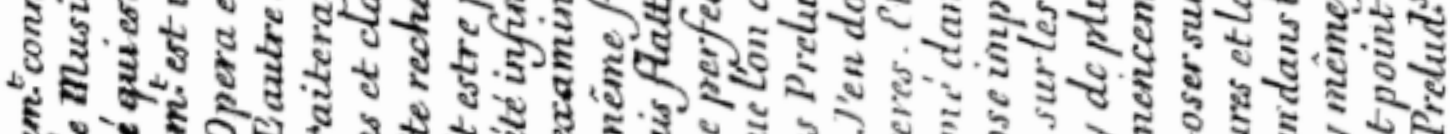

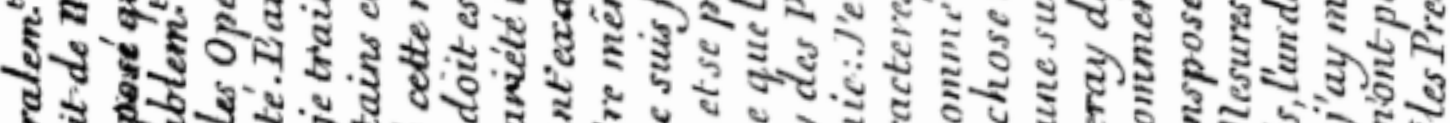

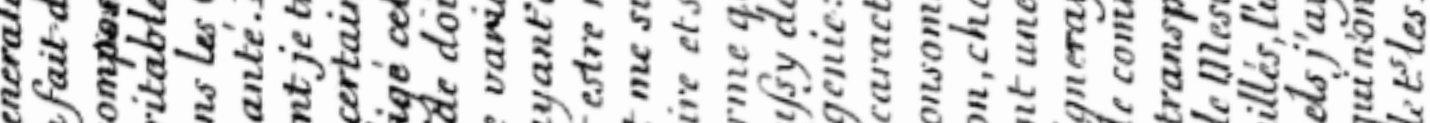

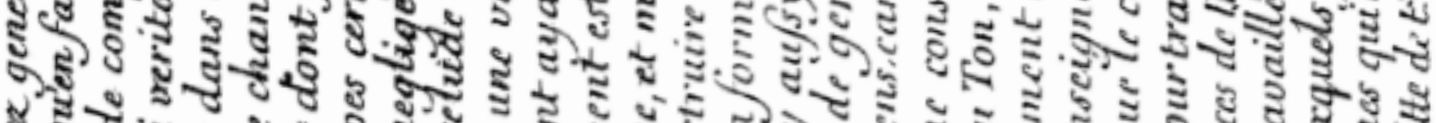

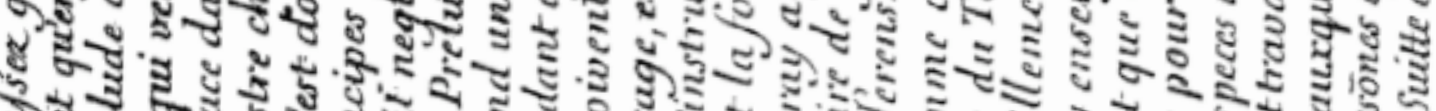

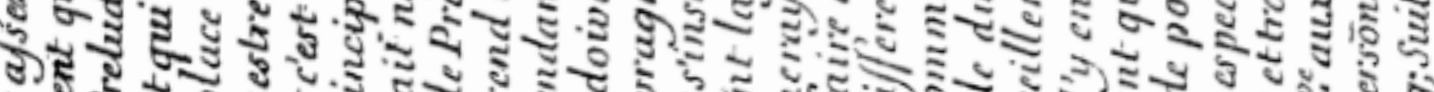

$\therefore$ है

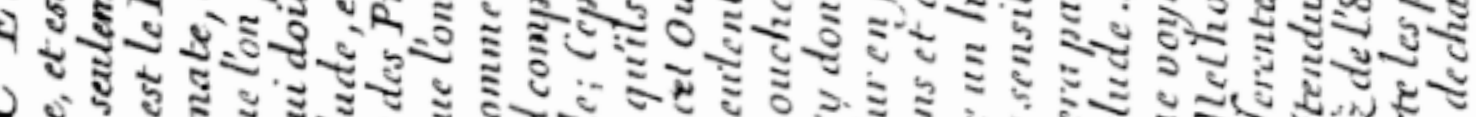

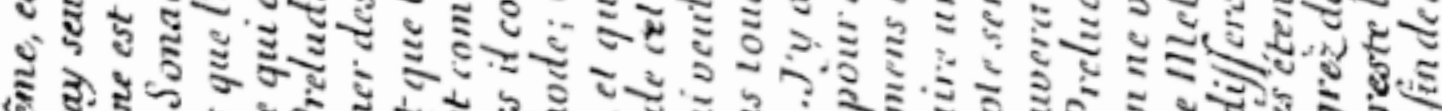

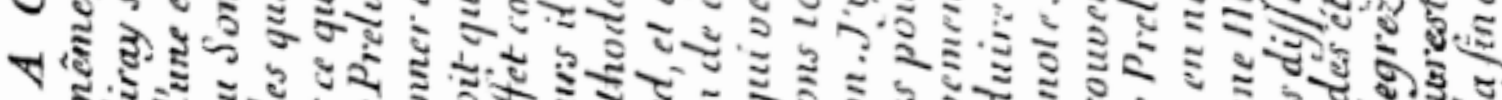

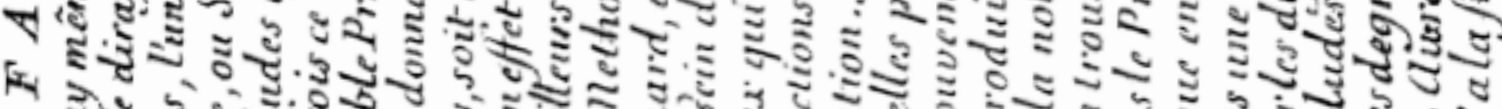

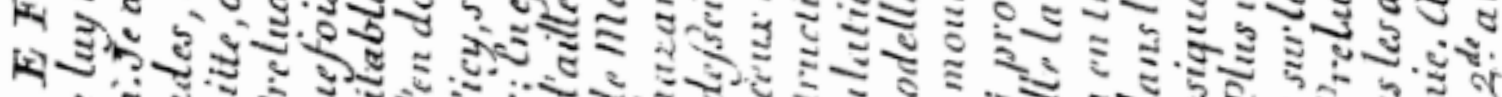
หช่.

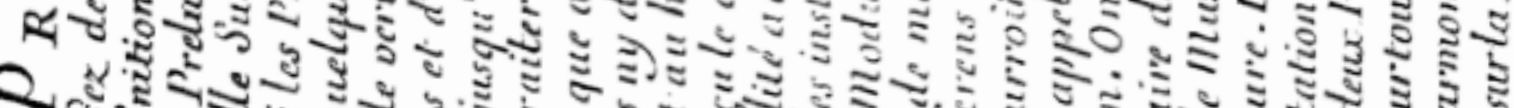

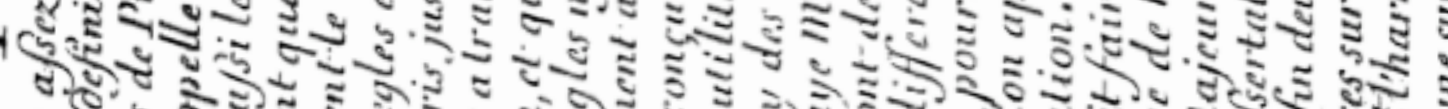

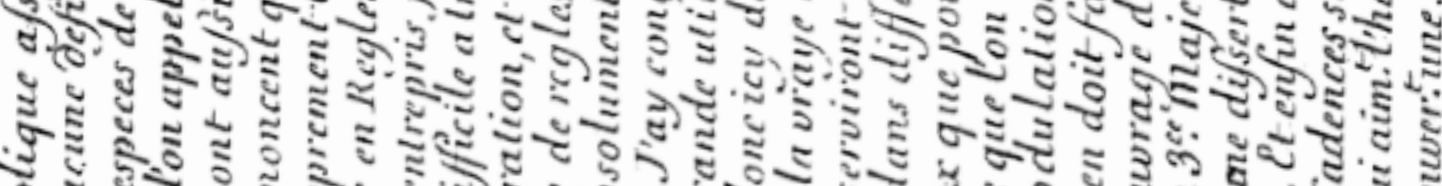
年

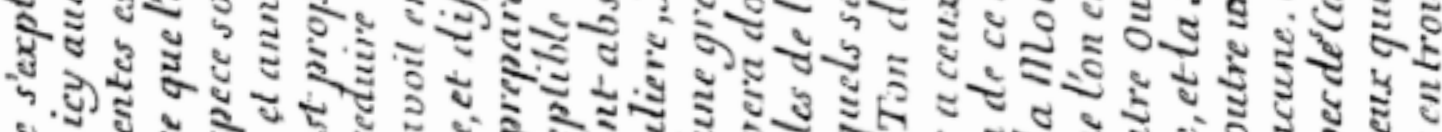

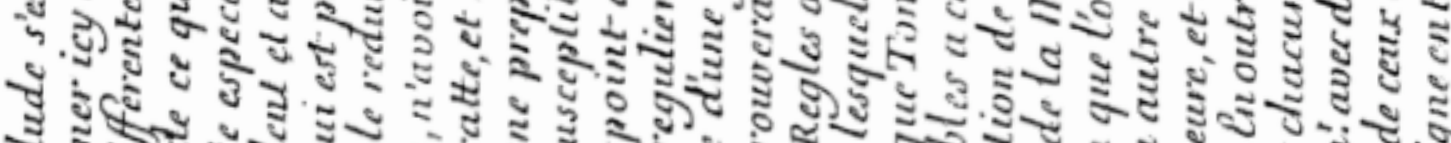

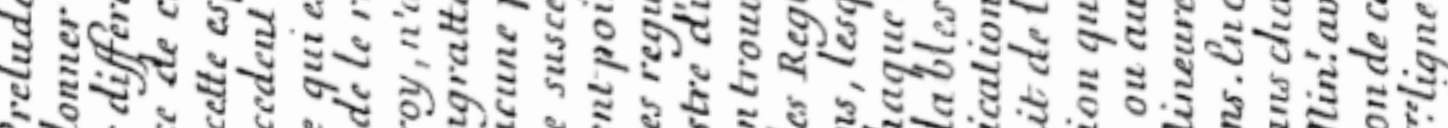

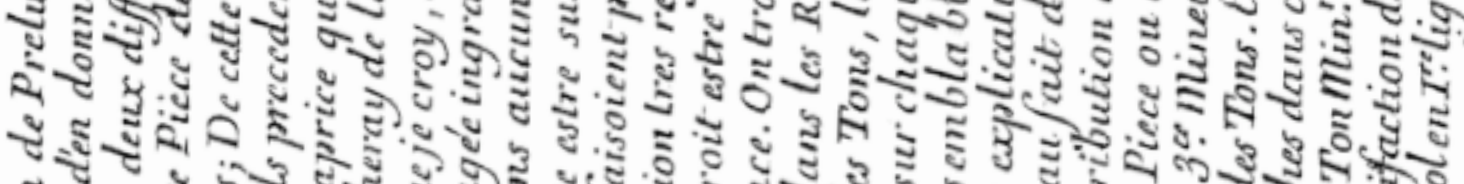

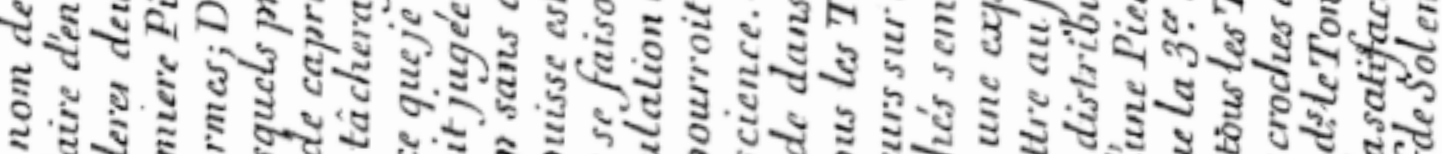
ร.)

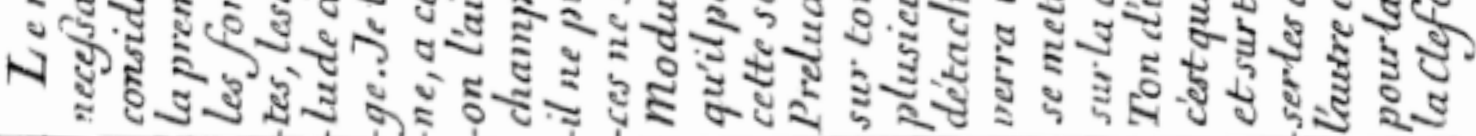




\section{Prefácio}

A palavra prelúdio é suficientemente explicativa, e geralmente conhecida, sem que seja necessária aqui alguma definição. Eu direi somente que a respeito da Música ${ }^{195}$ nós podemos considerar duas diferentes espécies de prelúdios. Uma é o prelúdio composto, que é comumente a primeira peça daquela que chamamos Suíte ou Sonata, e que de fato é uma peça entre as formas; dessa espécie são também os prelúdios localizados nas Óperas e nas Cantatas, os quais precedem e anunciam às vezes o que deve ser cantado. A outra espécie é o prelúdio de capricho [prélude de caprice], que é propriamente o verdadeiro prelúdio e que será tratado nesta Obra.

Eu procurarei reduzi-lo em regras e delas dar os princípios certos e claros ${ }^{196}$, que eu acredito que ninguém o tenha tratado até agora; seja porque havíamos negligenciado esse estudo, seja porque o tínhamos julgado ingrato e difícil de tratar.

Com efeito, como o prelúdio deve ser produzido imediatamente sem nenhuma preparação, e de certa forma, abrange uma variedade infinita, parece não estar susceptível a regras e nem a método ${ }^{197}$; no entanto, tendo examinado esses caprichos [prelúdios], eles não são feitos ao acaso, e sim fundamentados sobre uma modulação muito regrada.

Eu concebi a estrutura ${ }^{198}$ desta obra e fiquei lisonjeado ao mesmo tempo que esta poderá ser de grande utilidade aos que querem se instruir e se aperfeiçoar nesta Ciência ${ }^{199}$. Encontrar-se-ão aqui instruções a respeito da forma que deve ser dada a um prelúdio dentro das regras da verdadeira modulação.

Aqui darei também exemplos de prelúdios em todos os tons que servirão de modelos para deles fazer o engenho ${ }^{200}$, em diferentes movimentos e diferentes

195 O autor faz uso do termo Música em letra maiúscula referindo-se à Ciência Música, como em Furetière: "A ciência que ensina fazer acordes agradáveis à orelha, e que regula a harmonia, ou uma ciência pela qual se faz uma disposição dos sons graves e agudos proporcionais entre eles, e separa por justos intervalos, cujo os sentidos e a razão são satisfeitos." Cf. FURETIÈRE, Antoine. Op. cit., vol. II.

196 Sobre os princípios certos e claros das regras do prelúdio, Furetière diz dos fundamentos das artes e das ciências. Ele afirma ainda que não se deve comprovar os princípios, é necessário que eles sejam claros, que sejam noções comuns, daí a afirmação de Hotteterre. Furetière conclui dizendo que princípios são as primeiras regras ou máximas de uma arte. Cf. FURETIÈRE, Antoine. Op. cit., vol. III.

197 O termo variedade que para Furetière é sinônimo de diversidade, para Hotteterre está associado à tradição retórica da qualidade essencial do estilo, variar para deleitar, segundo Molinié: "plaire pour persuader", agradar para persuadir. Cf. MOLINIÉ, G. Op. cit., p. 333. No entanto, a variedade do prelúdio está sujeita a regras. Hotteterre menciona o termo método que para Furetière significa a arte de dispor as coisas de uma maneira que se possa fazê-la, ensiná-la, ou retê-la com mais facilidade. Cf. FURETIÈRE, Antoine. Op. cit., vol. III.

198 O termo dessein - traduzido como estrutura - para Furetière significa o pensamento que se tem na imaginação da ordem, da distribuição e da construção de um quadro, de um poema, de um livro. Brossard em 1708 diz que le dessein não é para ele apenas a intenção de fazer qualquer coisa, motivo ['intention de faire quelque chose, 'motif']. Blainville mais tarde, em 1754 prefere a palavra 'tissu' (estrutura) e sugere que exista uma espécie de retórica para o canto como para o discurso.

199 O termo instruir utilizado por Hotteterre está relacionado aos termos método, regras e princípios. Adquirir conhecimento ou mesmo aprender algo, é como Furetière define esse verbo. Cf. FURETIÈRE, Antoine. Op. cit., vol. II.

200 Do significado do termo engenho na obra de Hotteterre, ver o terceiro capítulo deste trabalho. 
caracteres $^{201}$; e também alguns traits ${ }^{202}$, similares àqueles que seriam produzidos por um homem perito nesta arte.

Será encontrada aqui uma explanação a respeito daquilo que chamamos a nota sensível do tom, algo importante para reconhecer uma modulação. Encontraremos paralelamente outra explicação a respeito das cadências e da sua distribuição que se deve fazer em um prelúdio.

Eu ensinarei, além disso, a conhecer o tom de uma peça ou outra obra de música não vendo somente o início da peça. Assim também o que é a terça menor e a terça maior, mais um método para transpor em todas as claves e em todos os tons. Além disso, uma dissertação sobre as diferentes espécies de compassos e a maneira de tocar cada uma das colcheias.

Enfim, dois prelúdios vastos e trabalhados, um no tom maior e o outro no tom menor, com cadências em todos os graus da oitava, aos quais eu mesmo juntei o baixo para a satisfação dos que amam a harmonia.

De resto, as pessoas que não têm o hábito de ler na clave de sol na primeira linha encontrarão aqui um prelúdio na segunda linha no fim de cada sequência de prelúdios contidos neste livro.

201 A respeito do termo caractères traduzido como caracteres (plural de caráter), ver o terceiro capítulo deste trabalho.

202 Ver nota 204 e os exemplos do quarto e sexto capítulos desta tradução. 


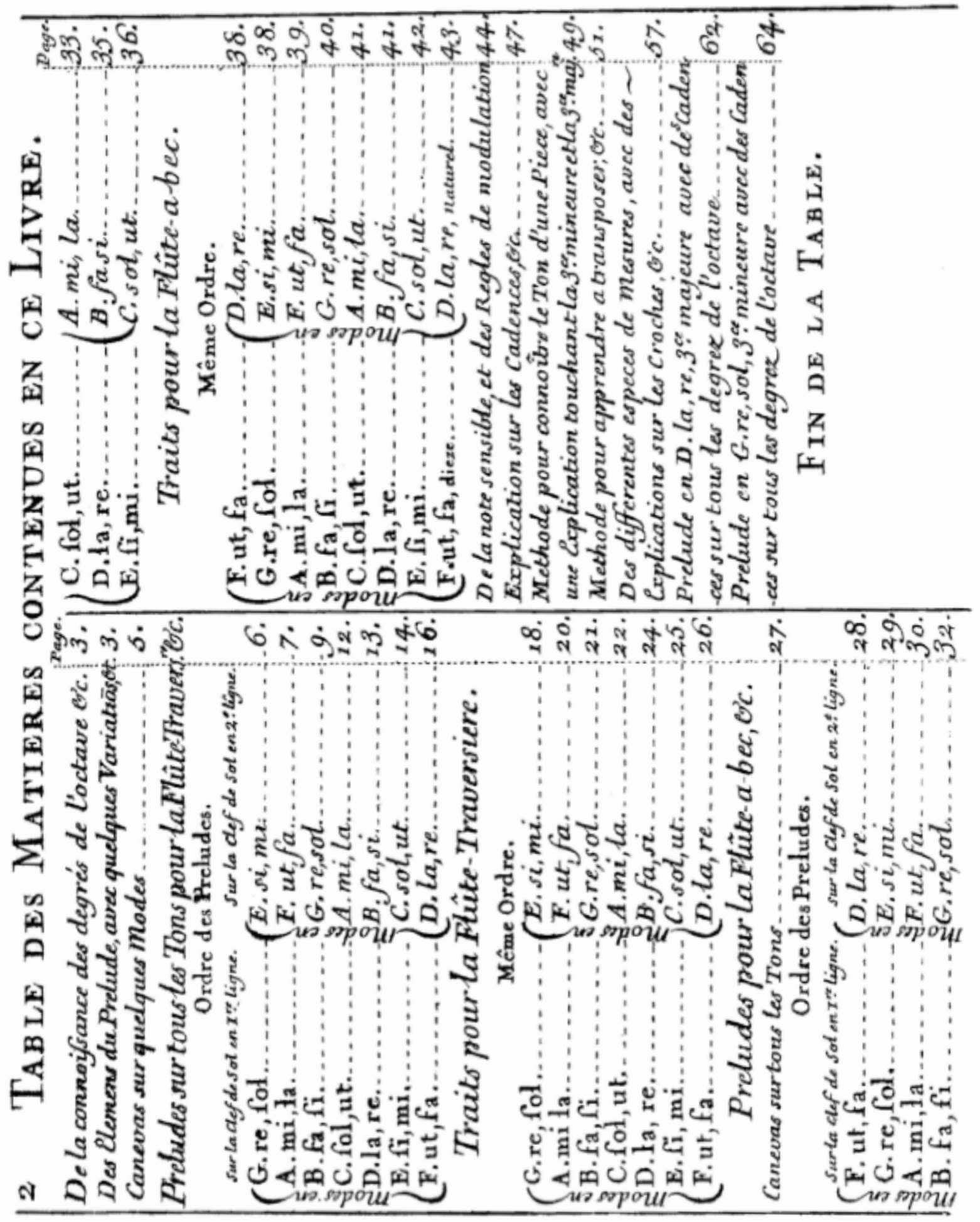




\section{Índice}

Do conhecimento dos graus da oitava (p. 95)

Dos elementos do prelúdio com algumas

variações etc. (p. 97)

Canevas $^{203}$ sobre alguns modos (p. 103)

Prelúdios em todos os tons para a flauta

traversa

Ordem dos prelúdios

\begin{tabular}{|l|l|l|}
\hline $\begin{array}{l}\text { Na Clave de sol } 1^{\mathrm{a}} \text { linha } \\
\text { Modos em }\end{array}$ & $\begin{array}{l}\text { Na Clave de sol } 2^{\mathrm{a}} \text { linha } \\
\text { Modos em }\end{array}$ \\
\hline G ré sol & E si mi & p. 105 \\
\hline A mi lá & F ut fá & p. 106 \\
\hline B fá si & G ré sol & p. 108 \\
\hline C sol ut & A mi lá & p. 111 \\
\hline D lá ré & B fá si & p. 112 \\
\hline E si mi & C sol ut & p. 113 \\
\hline F ut fá & D lá ré & p. 115 \\
\hline
\end{tabular}

Traits 204 para a flauta traversa

Mesma ordem

Na Clave de sol $1^{\text {a }}$ linha $\quad$ Na Clave de sol $2^{\text {a }}$ linha

Modos em

G ré sol

A mi lá

B fá si

C sol ut

D lá ré

E si mi

F ut fá Modos em

\begin{tabular}{l|l|} 
E si mi & p. 119 \\
\hline
\end{tabular}

p. 121

F ut fá

G ré sol

A mi lá

p. 122

p. 123

B fá si

p. 125

Da nota sensível e das regras de modulação. (p. 149).

Explicação sobre as cadências. (p. 157).

Método para conhecer os tom de uma peça com uma explicação relativa

à terça menor e à terça maior. (p. 161).

Método para aprender a transpor. (p. 165).

Das diferentes espécies de compassos ${ }^{205}$ com explicação sobre as colcheias. (p. 177).

Prelúdio em D lá ré, terça maior com cadências sobre todos os graus da oitava. (p. 195).

Prelúdio em G ré sol, terça menor com cadências sobre todos os graus da oitava. (p. 198).

Fim do índice

203 O termo caneva pode ser traduzido como plano. Furetière o define como as primeiras palavras a partir das quais se compõe uma ária para, em seguida, fazer outras mais regulares. Diz-se ainda de um plano de poema, de romance etc. Uma explicação mais detalhada é encontrada no terceiro capítulo deste trabalho.

204 O termo trait pode ser traduzido como traço. O Dictionnaire de l'Académie Française de 1718 expressa uma condição de 'modelos', 'pontos' de um discurso. Se dit aussi des beaux endroits d'un discours, de ce qu'il y a de plus vif e de plus brillant. II y a de beaux traits dans ce discours. Benoit o define como ornamentos do canto e dos instrumentos. Mais informações sobre o significado desse termo para a Arte de Preludiar de Hotteterre são encontradas no terceiro capítulo deste trabalho.

205 O termo francês mesure pode ser traduzido como medida ou compasso, de acordo com Furetière. Como nesta parte do tratado Hotteterre se refere à métrica em música (medida do tempo musical), será utilizado o termo compasso. Cf. FURETIÈRE, Antoine. Op. cit., vol. II. 


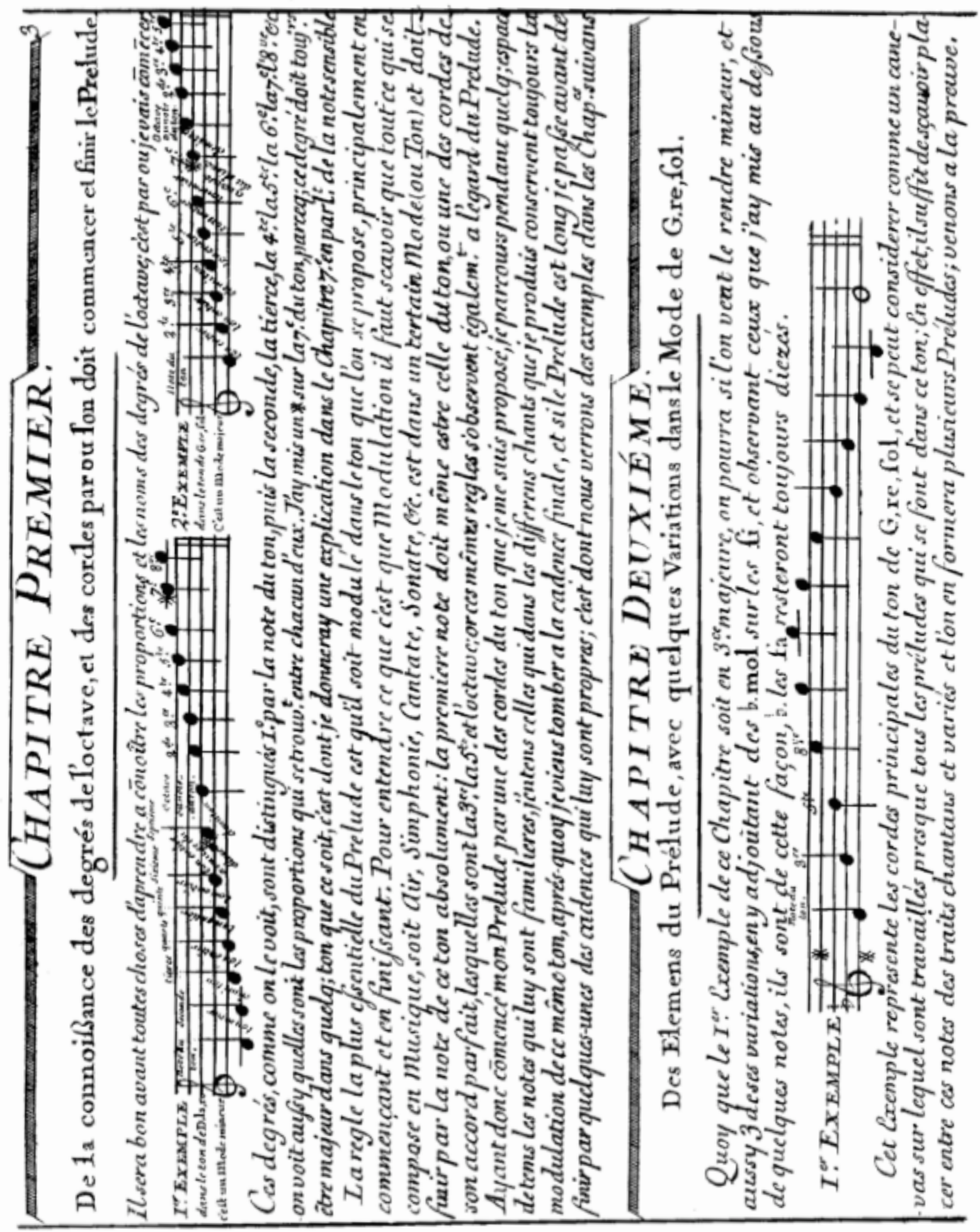




\section{Primeiro Capítulo}

\section{Do conhecimento dos graus da oitava, e das $\operatorname{cordas}^{206}$ por onde se deve começar e terminar o prelúdio.}

Será bom, antes de todas as coisas, aprender a conhecer as proporções e os nomes dos graus da oitava; é por onde irei começar.

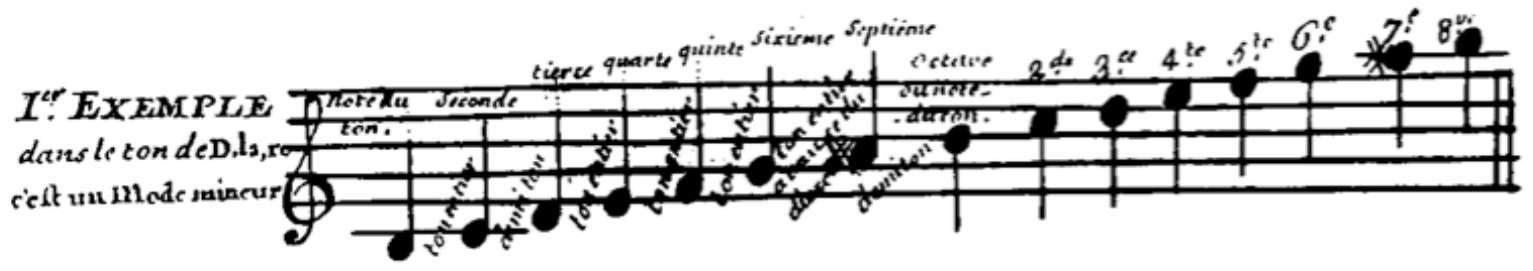

Primeiro exemplo: Sobre o tom de D lá ré que é um modo menor. Nota do tom; (tom inteiro); segunda; (semitom); terça; (tom inteiro); quarta; (tom inteiro); quinta; (tom inteiro); sexta; (tom inteiro por causa do \#); sétima; (semitom); oitava ou nota do tom; segunda; terça; quarta; quinta; sexta; sétima; oitava.

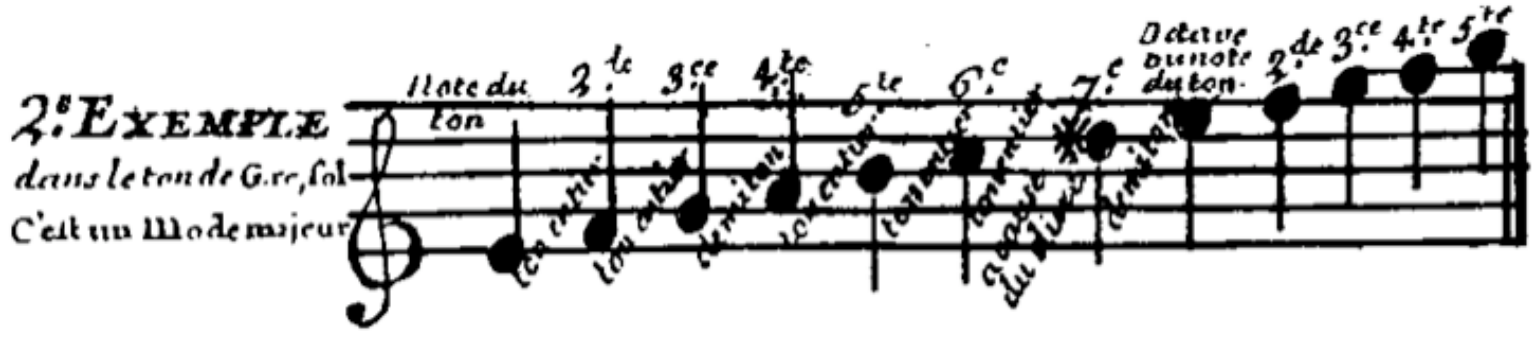

Segundo exemplo: Sobre o tom de G ré sol que é um modo maior. Nota do tom; (tom inteiro); segunda; (tom inteiro); terça; (semitom); quarta; (tom inteiro); quinta; (tom inteiro); sexta; (tom inteiro por causa do \#); sétima; (semitom); oitava ou nota do tom; segunda; terça; quarta; quinta.

Esses graus, como se vê, são distinguidos, em primeiro lugar, pela nota do tom, em seguida pela segunda, pela terça, quarta, quinta, sexta, sétima e oitava etc.; vê-se também quais são as proporções (intervalos) que se encontram entre cada uma delas. Coloquei um sustenido sobre a sétima nota do tom, porque este grau deve ser sempre maior em qualquer tom que seja, e sobre o qual darei uma explicação no sétimo capítulo, falando da nota sensível.

206 O termo cordas é definido pelo Dictionnaire Portatif des beaux-arts como notas contidas na extensão de uma oitava. "Terme de Musique par lequel on entend non seulement les cordes d'un Instrument, mais encore toutes les notes ou sons sensibles, qui sont renfermés dans l'étendue de l'octave". Cf. LACOMBE, Jacques. Dictionnaire portatif des beaux-arts, ou Abrégé de ce qui concerne l'architecture, la sculpture, la peinture, la gravure, la poésie et la musique. Paris: vve Estienne et fils et J.-T. Hérissant, 1752. http:// gallica.bnf.fr/. Acesso em: 10 de jan 2009. 
A regra mais essencial do prelúdio é que este seja modulado no tom que se propõe, principalmente no início e no fim. Para entender o que é modulação ${ }^{207}$, é necessário saber que tudo o que se compõe em música, seja Ária, Sinfonia, Cantata, Sonata, etc., está num certo modo (ou tom) ${ }^{208}$ e deve terminar na nota deste tom absolutamente: a primeira nota deve mesmo ser a do tom, ou uma das cordas do seu acorde perfeito, que são a terça, a quinta e a oitava; ora, essas mesmas regras observam-se igualmente em relação ao prelúdio. Consequentemente, começando meu prelúdio por uma das cordas do tom a que me propus, meu percurso durante algum espaço de tempo serão as notas que Ihe são familiares; entendo que nas diferentes melodias que produzo conservo sempre a modulação desse mesmo tom, e em seguida venho ao encontro da cadência final, e se o prelúdio é longo, passo antes de terminar por algumas das cadências que Ihe são apropriadas; e das quais veremos exemplos nos capítulos seguintes.

\section{Segundo Capítulo}

\section{Elementos do Prelúdio com algumas variações no modo de G ré sol.}

Embora o primeiro exemplo deste capítulo seja em terça maior, poder-se-á torná-lo menor; bem como três destas variações, acrescentando nelas um $b$ sobre os Sis, e observando os que coloquei embaixo de algumas notas, elas são desta maneira bemol; os fá permanecerão sempre sustenidos.

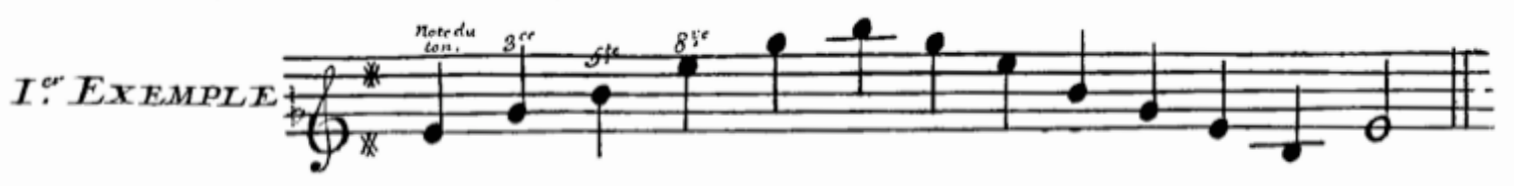

\footnotetext{
207 Para Furetière, modulação [modulation] é um termo de música que significa as mudanças de um som a outro de acordo com algumas notas ou consonâncias que são agradáveis ao ouvido. É o simples canto ou melodia [chant], que os antigos chamavam de melopée. Cf. FURETIÈRE, Antoine. Op. cit., vol. II. Bouissou diz que "para a maior parte dos compositores e teóricos, modular [moduler] consiste na alteração de tom. Vinculada ao princípio de tonalidade, a modulação participa do desenvolvimento do material musical como a elaboração do percurso tonal da obra e, portanto, da sua forma. Assim, a forma fuga é toda construída sobre o princípio do percurso tonal e vários teóricos empregam-se a classificar as diferentes modulações. No seu Traité de la fugue et du contrepoint de 1756, Marpurg define dois tipos principais de modulação: a modulação 'regular', que consiste em passar por um dos tons dados pelo tom inicial (ou seja, todos os graus da gama), e a modulação 'irregular', que modula nos tons alterados da gama inicial (por exemplo, fá\# em dó maior). Mas a modulação representa também um meio de expressão importante, ao ponto de que, para Rameau, a força da expressão depende muito mais da modulação que da simples melodia. Com a invenção da noção de centro harmônico, a descoberta da inversão dos acordes e a tese da formação dos acordes por terças, Rameau abre a via à harmonia moderna e às modulações mais audaciosas. Imaginando um som neutro central (dó), ele propõe um ciclo de quintas ascendentes onde cada nova quinta representa a dominante do tom precedente e, ao contrário, um ciclo de quintas descendentes onde cada nova quinta representa a subdominante do tom precedente. Se a modulação ao tom vizinho animar pouco o discurso, em contrapartida, a modulação ao tom afastado produz um efeito importante que, quando vai do lado das subdominantes, produz uma expressão triste, ou mesmo lúgubre, enquanto, quando vai do lado das dominantes, cria um efeito oposto". In: BOUISSOU, S. Op. cit., p. 130.

${ }^{208}$ A respeito do significado dos termos modo e tom, cf. o terceiro capítulo deste trabalho.
} 


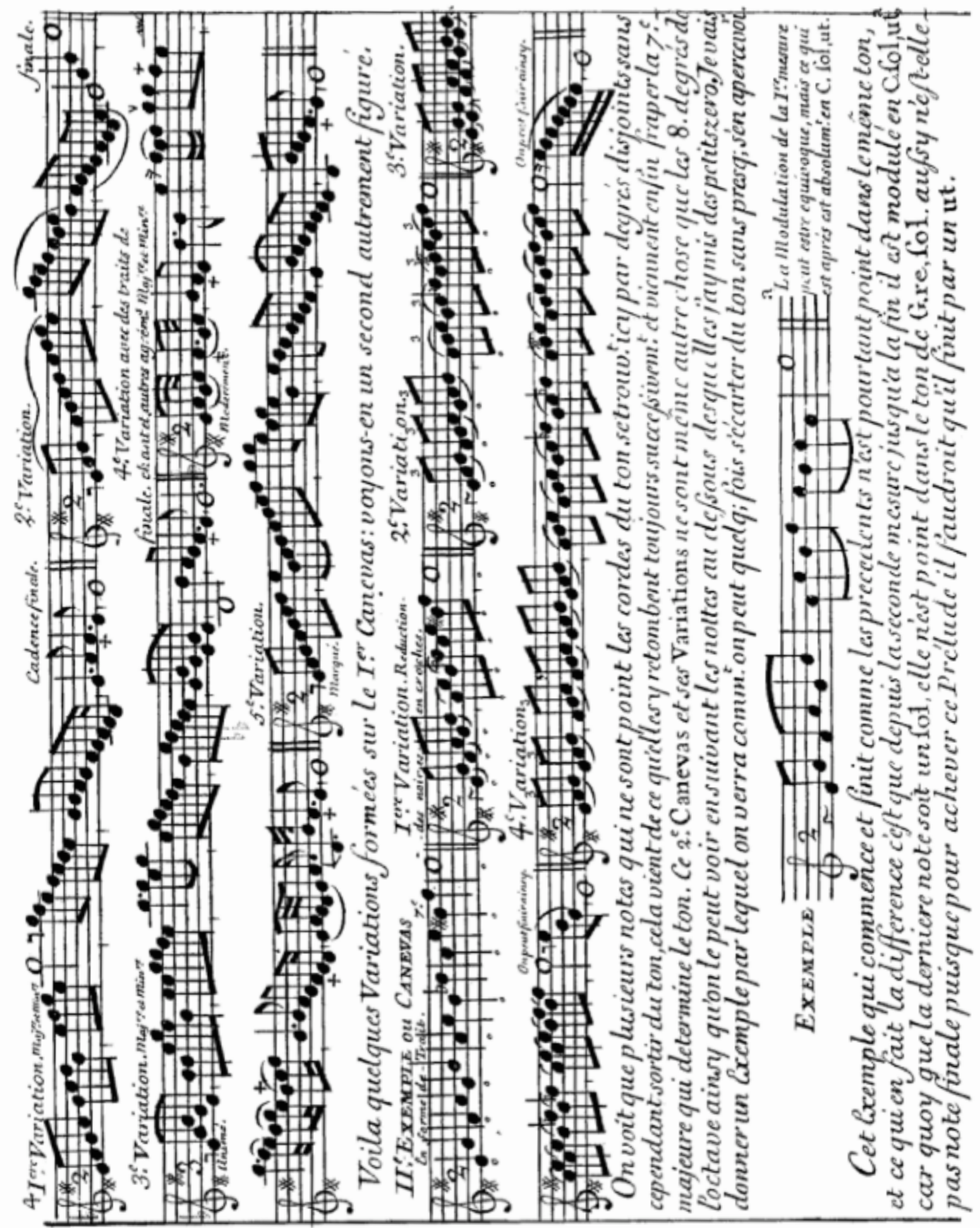


Este exemplo representa as cordas principais do tom de G ré sol, e pode-se considerar como um caneva sobre o qual são trabalhados quase todos os prelúdios que se fazem nesse tom. Com efeito, é importante saber colocar linhas melódicas variadas entre essas notas e com elas formar-se-ão vários prelúdios; passemos à prova:

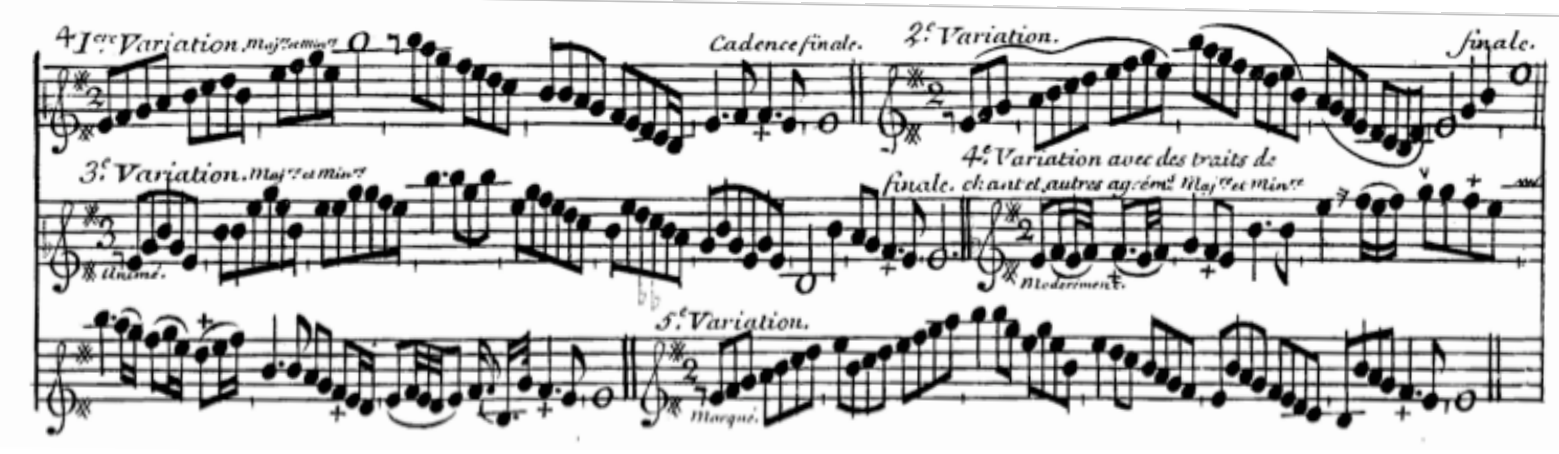

Aí estão algumas variações formadas sobre o primeiro caneva: vejam o segundo diferentemente variado ${ }^{209}$.

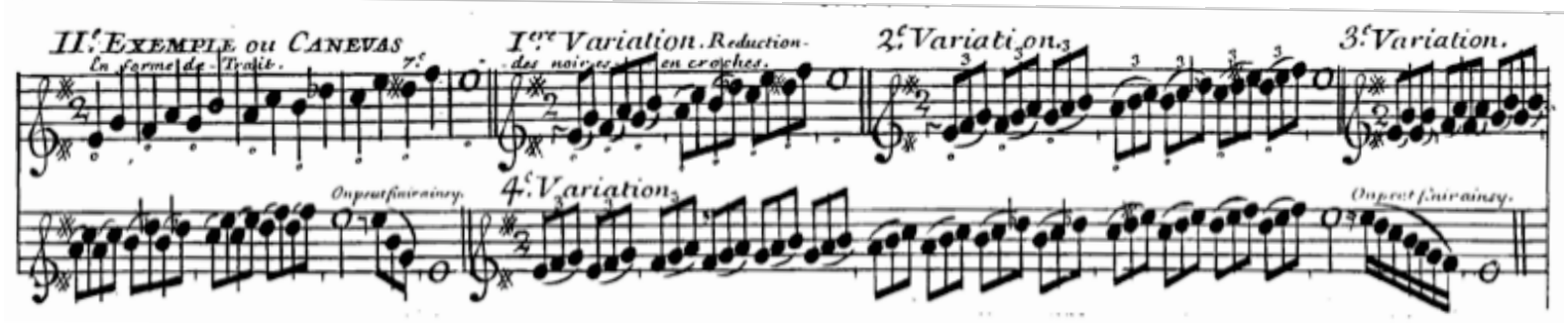

Vê-se que várias notas que não são as cordas do tom se encontram aqui por graus disjuntos sem contudo sair do tom; isso porque elas vêm sempre na sequência e vêm enfim atacar a sétima maior que determina o tom. Esse segundo caneva e essas variações não são outra coisa que os oito graus da oitava, assim como se podem vê-los seguindo as notas abaixo das quais coloquei pequenos zeros. Vou dar um exemplo pelo qual se verá como se pode, às vezes, afastar-se do tom sem que se perceba.

${ }^{209}$ O termo figuré foi traduzido como variado, ou seja, pleno de variações. Para Furetière se diz também estilo figurado [stile figuré], pleno de figuras [figure]. O termo figure significa um ornamento do discurso que consiste de palavras, ou de significados, ou de uma parte da oração. Cf. FURETIÈRE, Antoine. Op. cit., vol. II. 


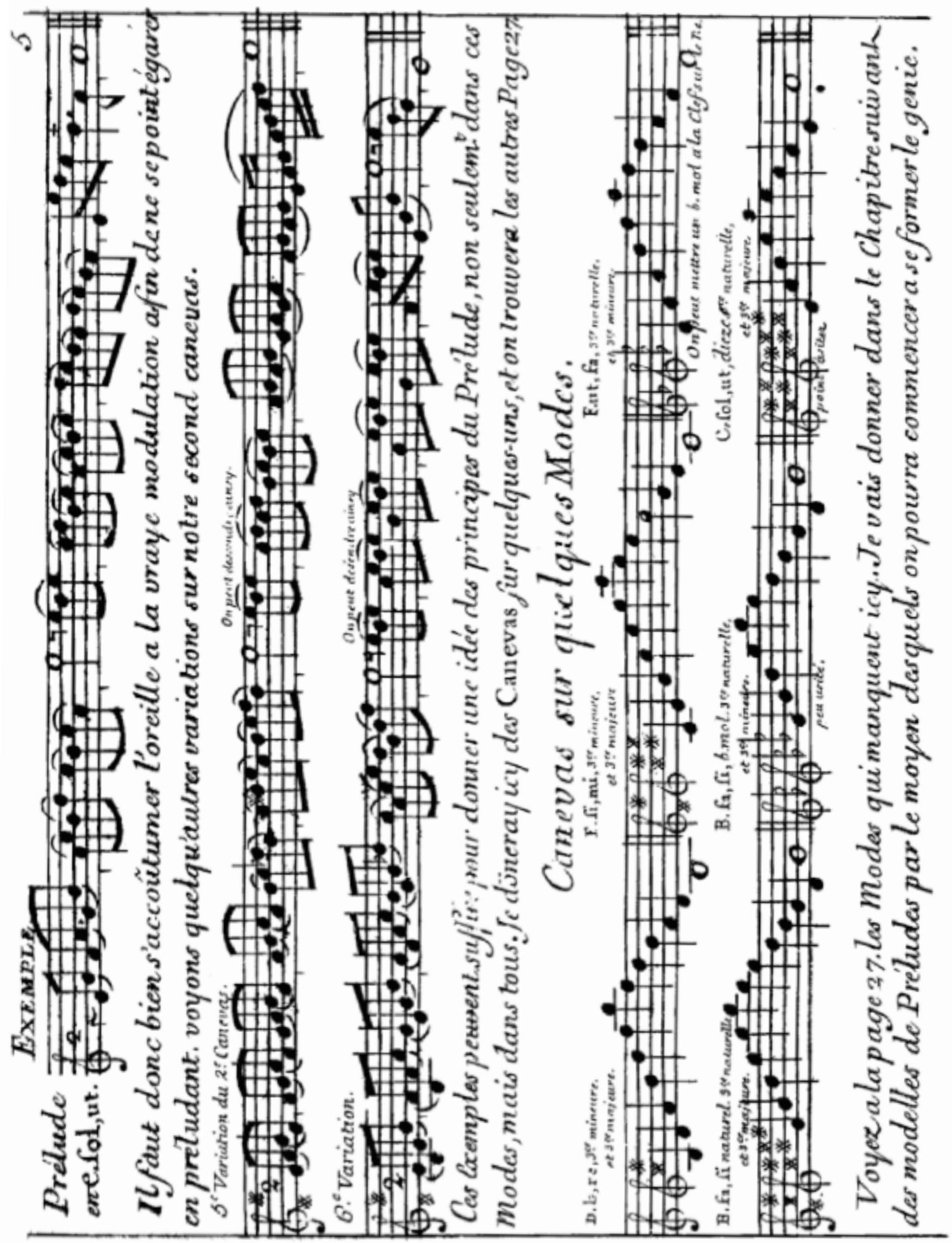




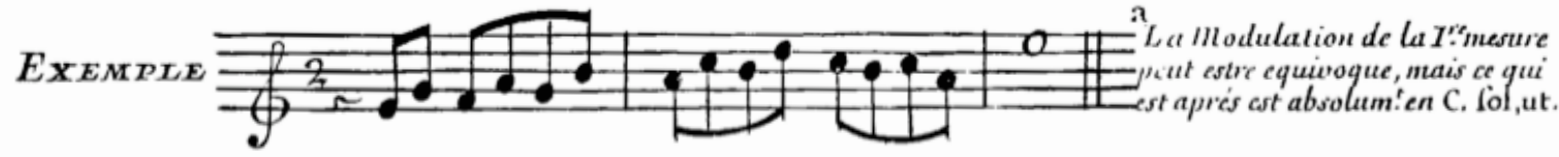

A modulação do primeiro compasso pode estar equivocada, mas o que vem depois está absolutamente em $\mathrm{C}$ sol ut.

No entanto, esse exemplo, que começa e termina como os precedentes, não está no mesmo tom. A diferença é que desde o segundo compasso até ao fim ele é composto em C sol ut; porque embora a última nota seja um sol, não está no tom de $\mathrm{G}$ ré sol, e portanto não é a nota final, pois para terminar esse prelúdio seria necessário terminar com um ut'210.

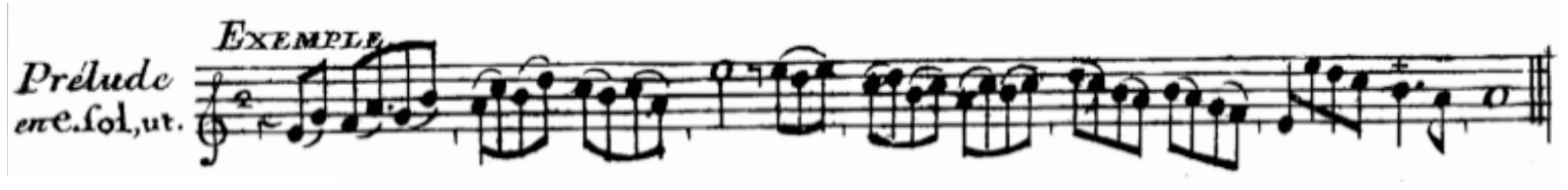

É preciso então habituar o ouvido à verdadeira modulação a fim de não se perder do preludiar. Veremos algumas outras variações sobre o nosso segundo caneva.

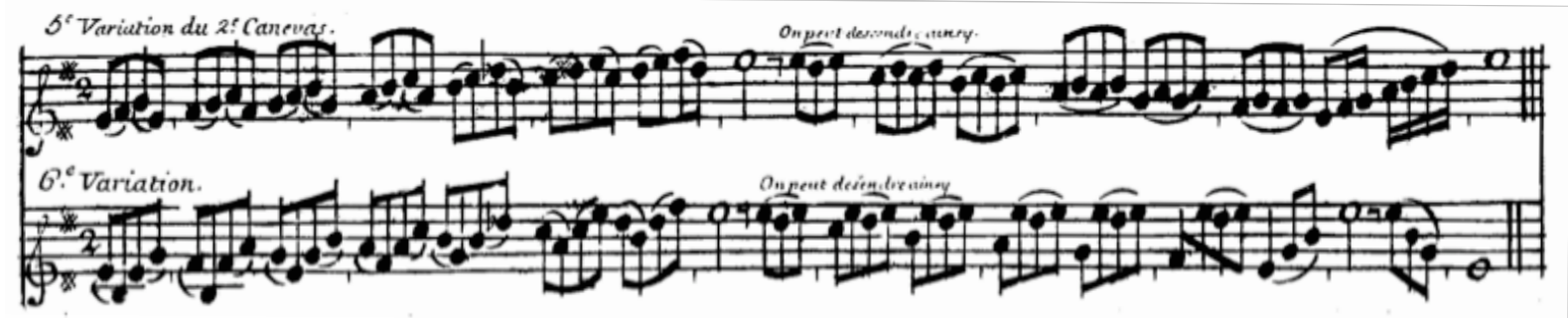

Esses exemplos podem ser suficientes para dar uma ideia dos princípios do prelúdio, não somente nesses modos, mas em todos. Darei aqui os canevas sobre alguns, e encontrar-se-ão os outros na página 129.

210 A terminologia dos modos utilizada por Hotteterre, ou seja, a prática de chamar as notas pelas letras (C, no caso) seguida do "solfejo" (sol, ut) é um hábito antigo que remonta à solmização de Guido D'Arezzo (995-1050). Nesse tempo as notas eram chamadas, dependendo do hexacorde ao qual pertenciam:

Gamma ut

A re

$B$ mi

C fa ut

D sol re

Ela mi

F faut

g solre ut

a la mi re etc.

O hábito de denominar as notas dessa forma ainda vigorava no século XVIII, porém de maneira adaptada aos usos da época. No caso de Hotteterre, ele fornece a letra da tonalidade e as duas notas do "solfejo" que caracterizam a tonalidade, por exemplo A, mi, la. 


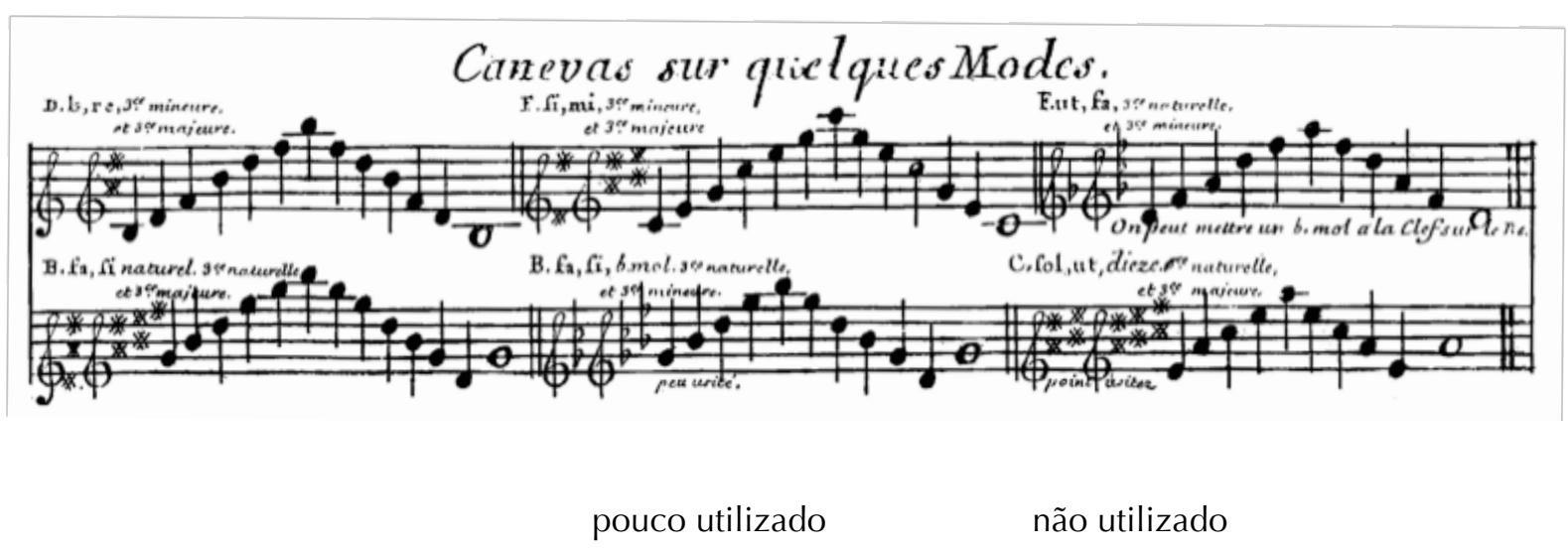

Vejam na página 129 os modos que faltam aqui. Vou dar no capítulo seguinte modelos de prelúdios graças aos quais se poderá começar a formar o engenho ${ }^{211}$.

211 É sob essa afirmação de Hotteterre que se torna claro o significado do seu pensamento e respeito da sua Arte de Preludiar. Isso é melhor detalhado no terceiro capítulo deste trabalho. 


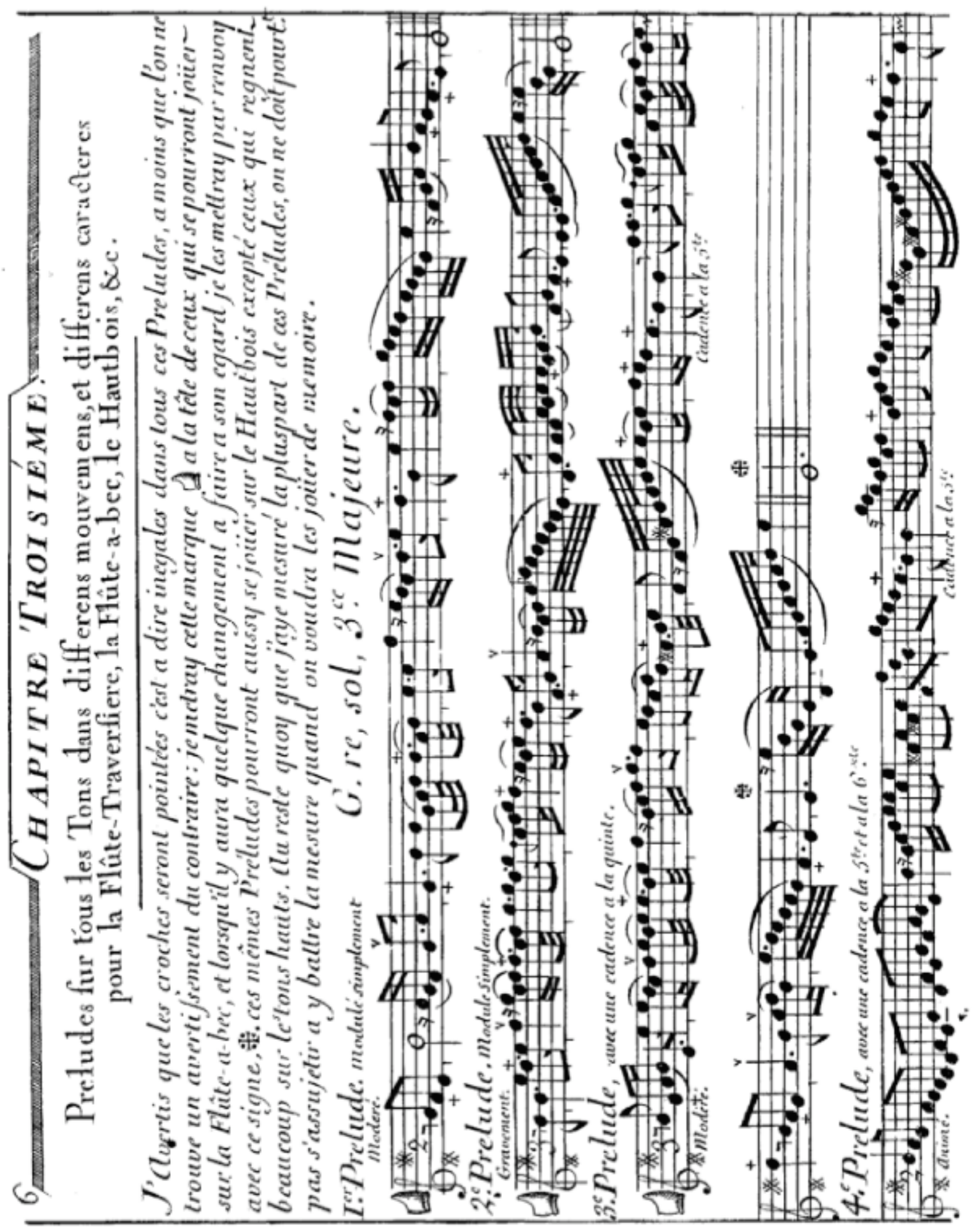




\section{Terceiro Capítulo}

\section{Prelúdios sobre todos os tons em diferentes movimentos e em diferentes caracteres para a flauta traversa, flauta doce e o oboé, etc.}

Previno que as colcheias serão pontuadas, ou seja, desiguais ${ }^{212}$ em todos os prelúdios, a menos que se encontre um aviso do contrário. Porei este sinal a no começo dos prelúdios que poderão ser tocados na flauta doce; e quando houver alguma mudança a fazer a seu respeito, colocarei este sinal :æ: para sinalizar a alteração [o desvio].

Estes mesmos prelúdios poderão também ser tocados no oboé, salvo os que permanecem sobre os tons agudos. De mais a mais, embora eu tenha medido a maior parte destes prelúdios, não se deve portanto se sujeitar aqui a bater o compasso [pulsar] quando se quiser tocá-lo de memória.

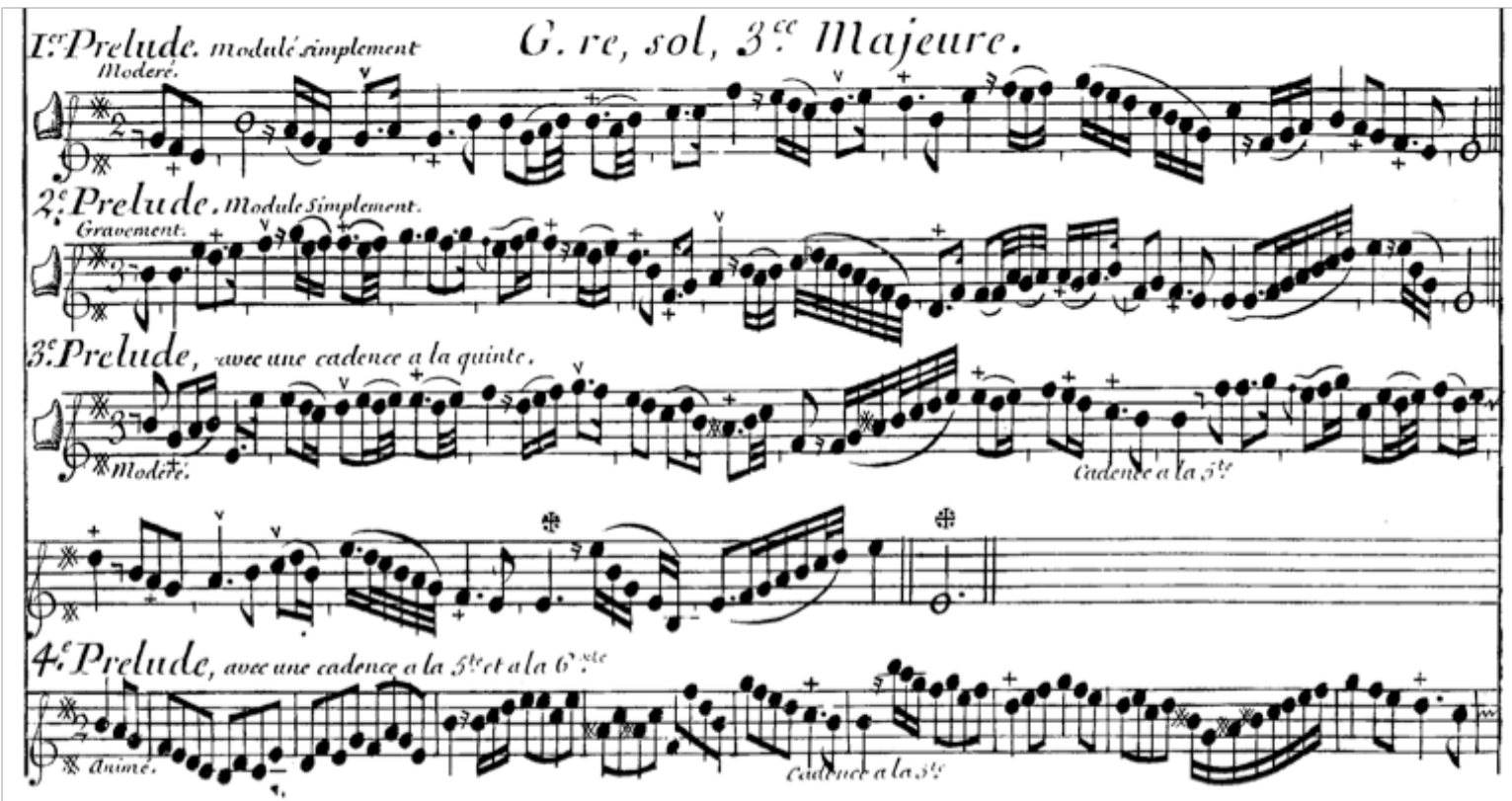

Primeiro Prelúdio: modulação simples; moderado. Segundo Prelúdio: modulação simples; gravemente. Terceiro Prelúdio, com uma cadência na quinta; moderado. Quarto Prelúdio, com uma cadência na quinta e na sexta; animado.

212 Hotteterre, quando se refere às colcheias, utiliza o termo pointer (pontuado) e em seguida explica afirmando ser sinônimo do termo inégale [inégalité]. Benoit define inégalité como um termo de interpretação da música barroca francesa que consiste em tornar desiguais em duração dois valores escritos iguais. Cf. BENOIT, M. Op. cit., p. 355. Informações mais detalhadas a respeito do uso do termo pointer e sua aplicação em relação aos instrumentos de sopro são encontradas no primeiro capítulo deste trabalho. 


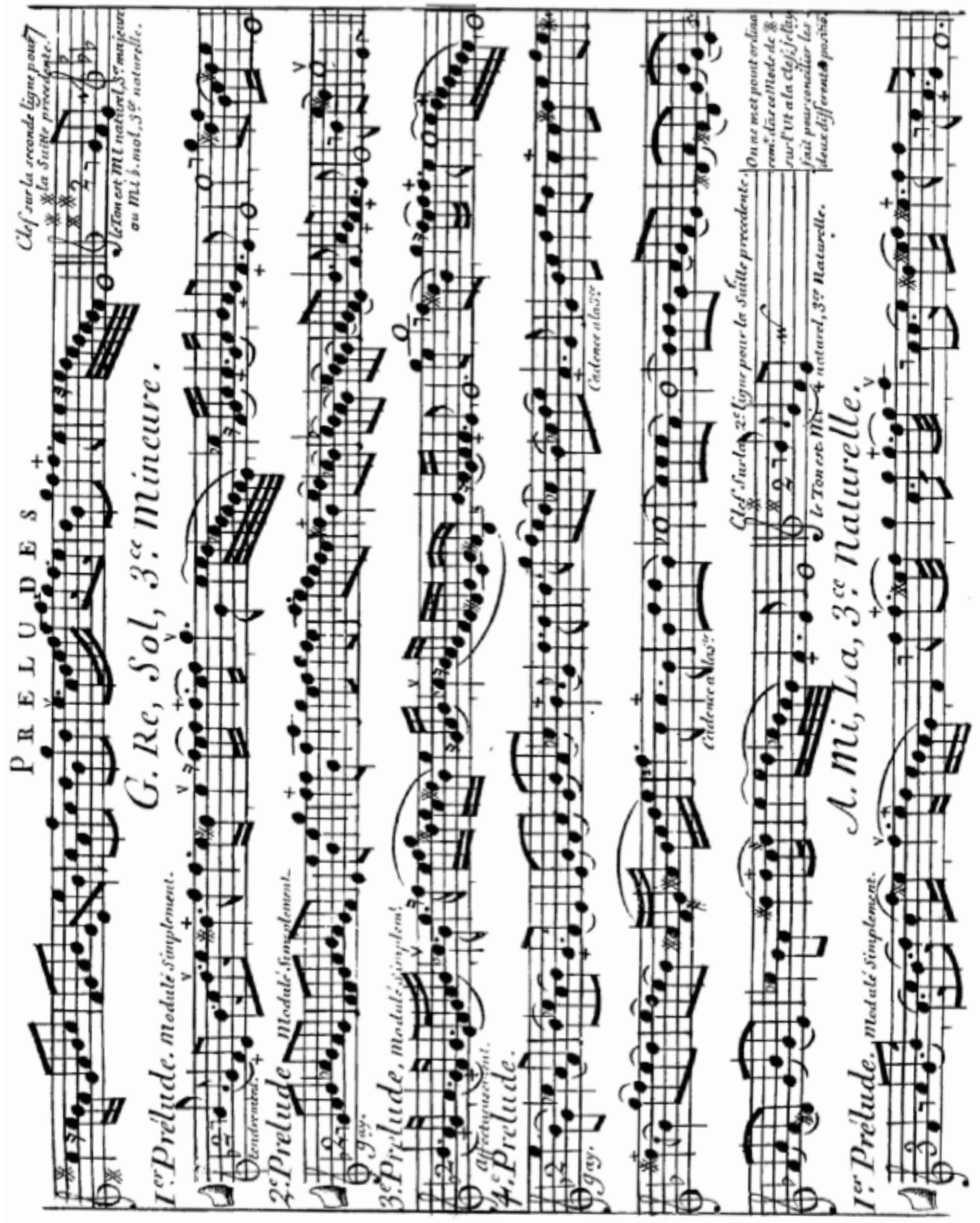

Geralmente não se coloca o sustenido do dó na armadura de clave; eu o fiz para acomodar as duas diferentes posições 


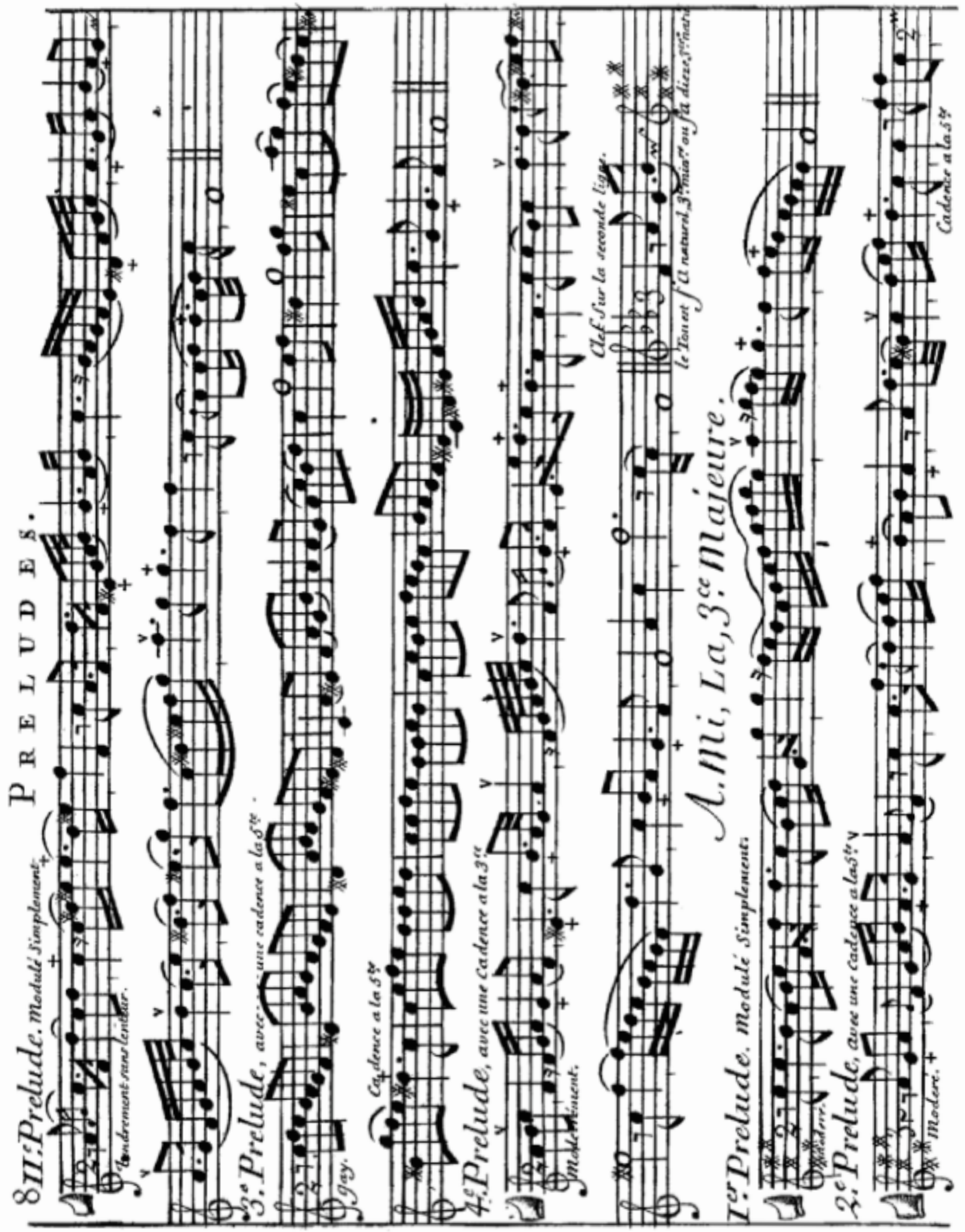




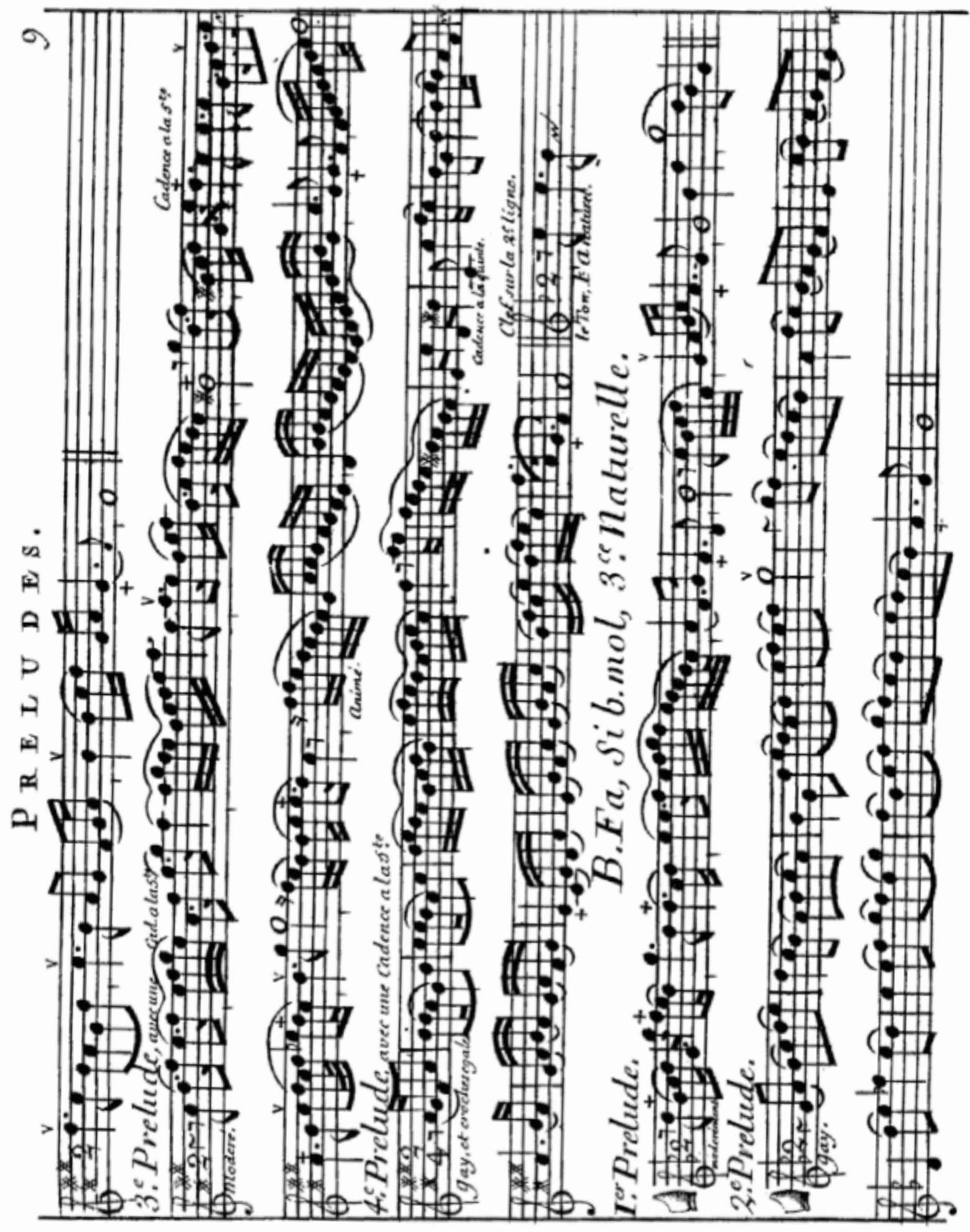




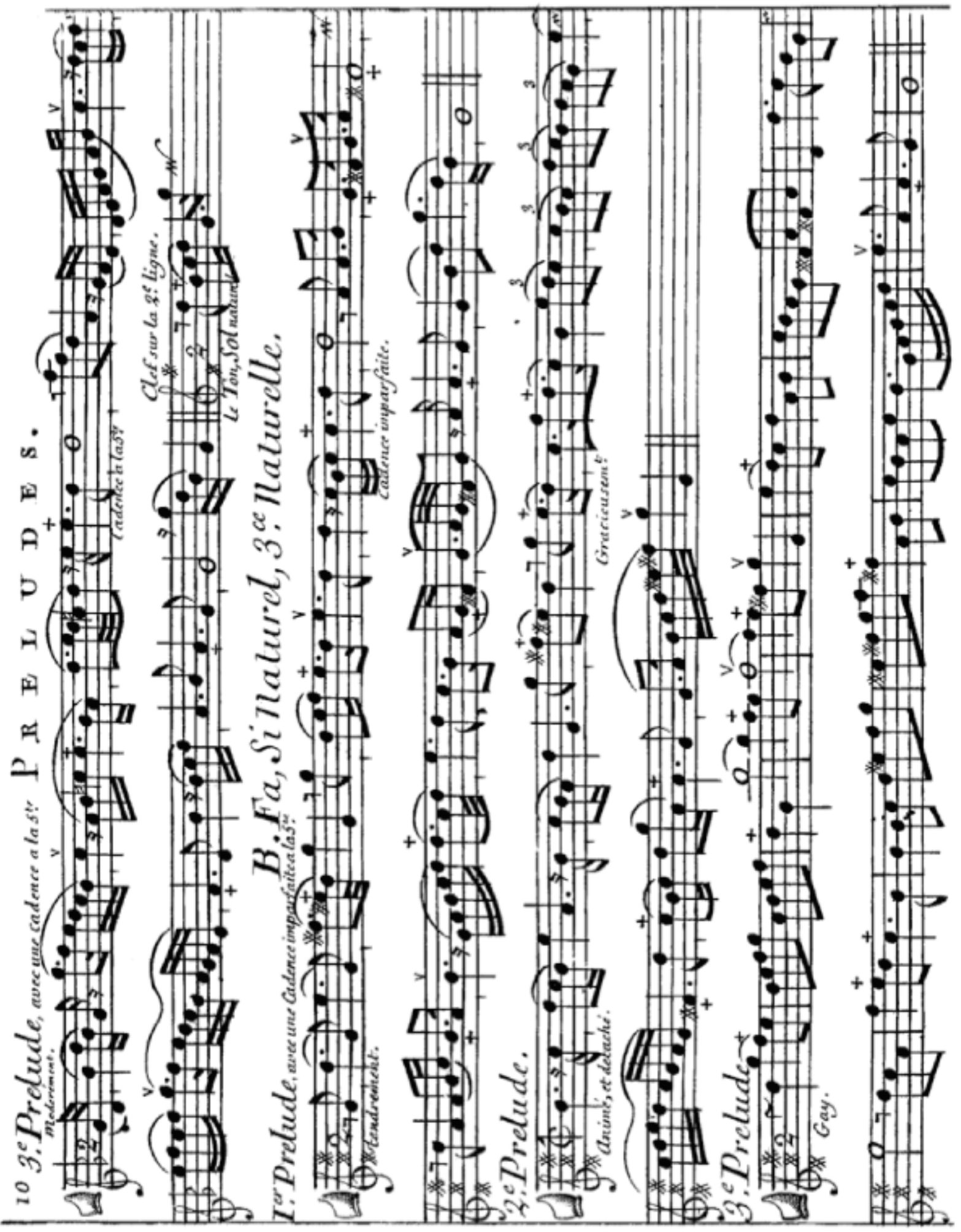




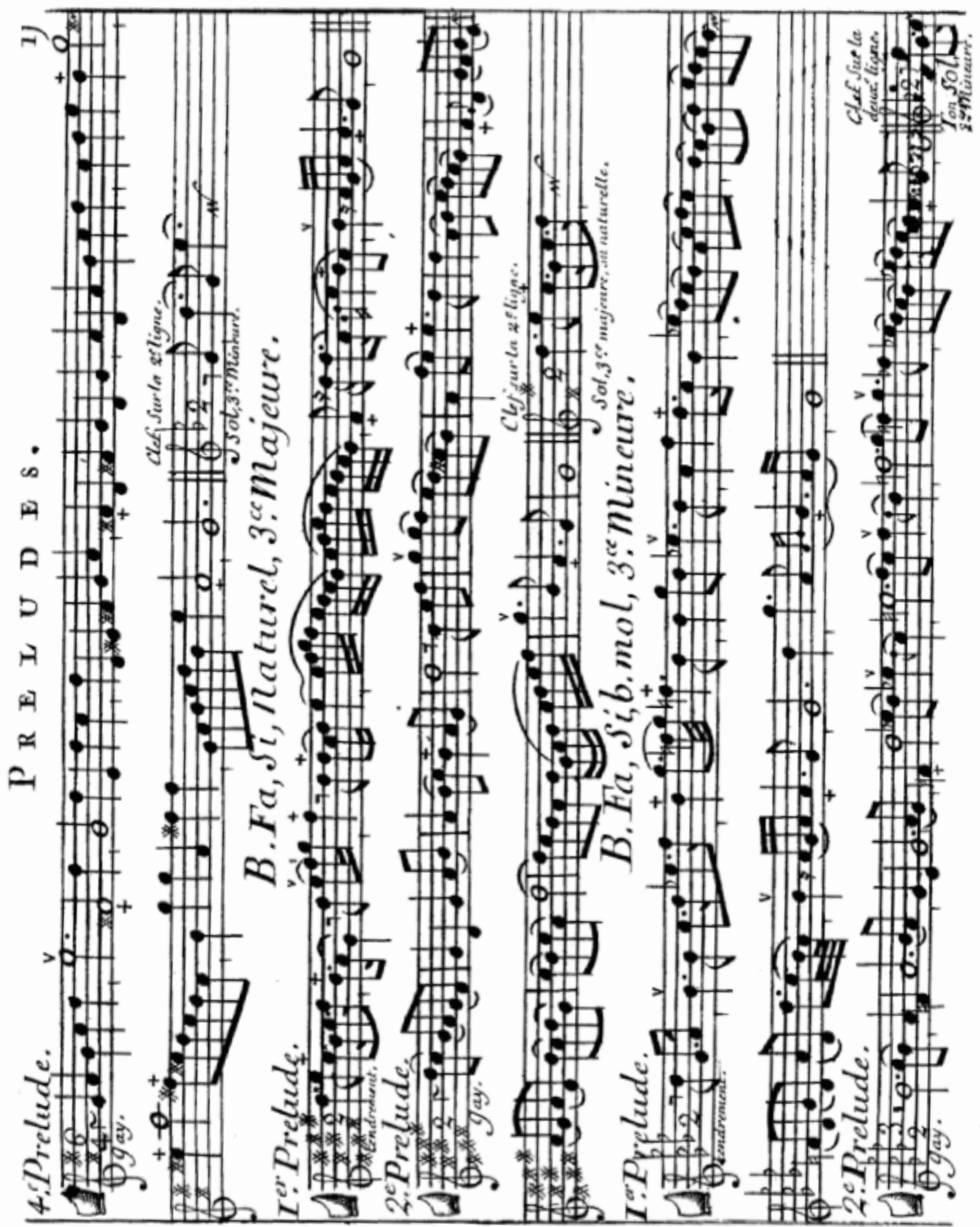




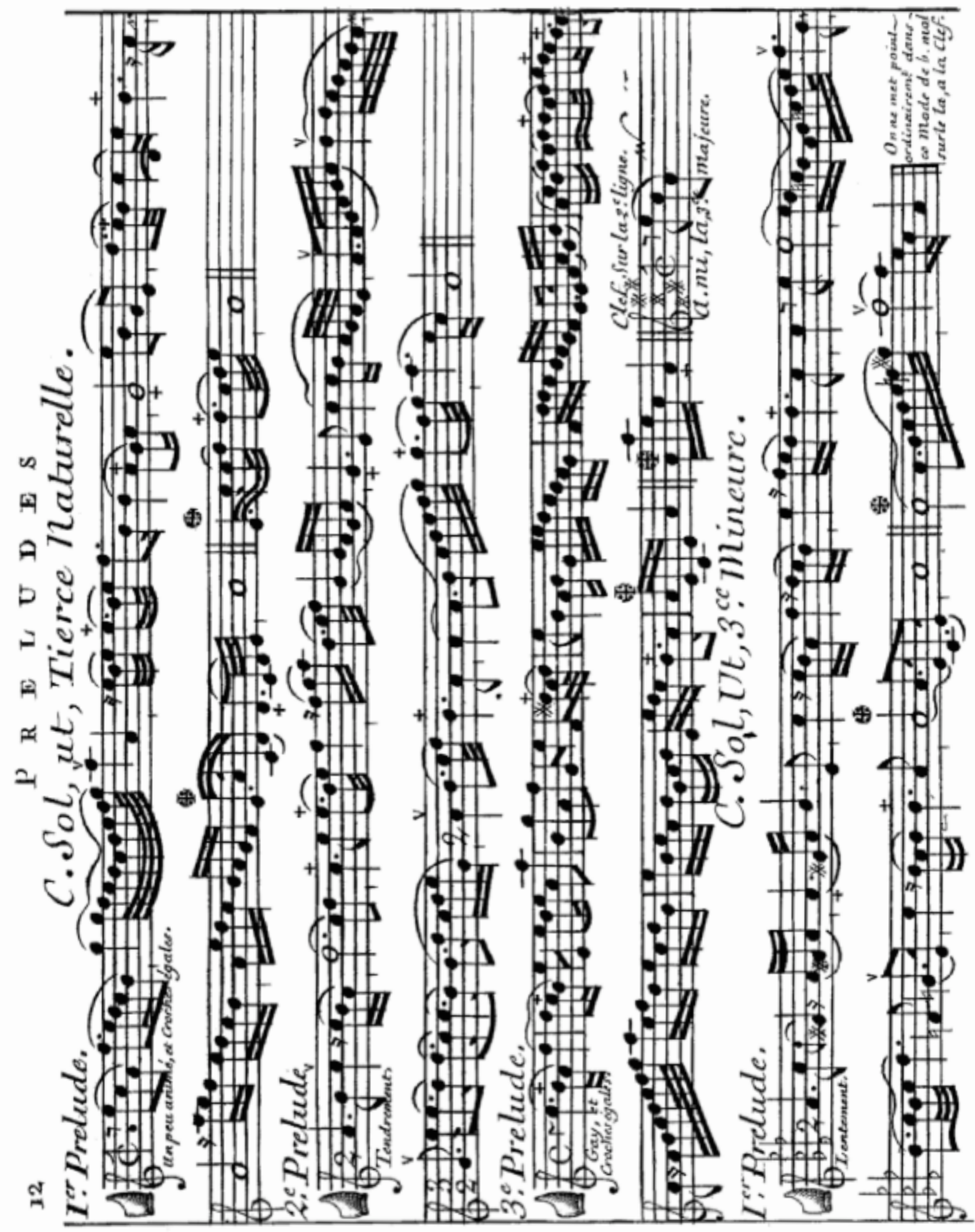




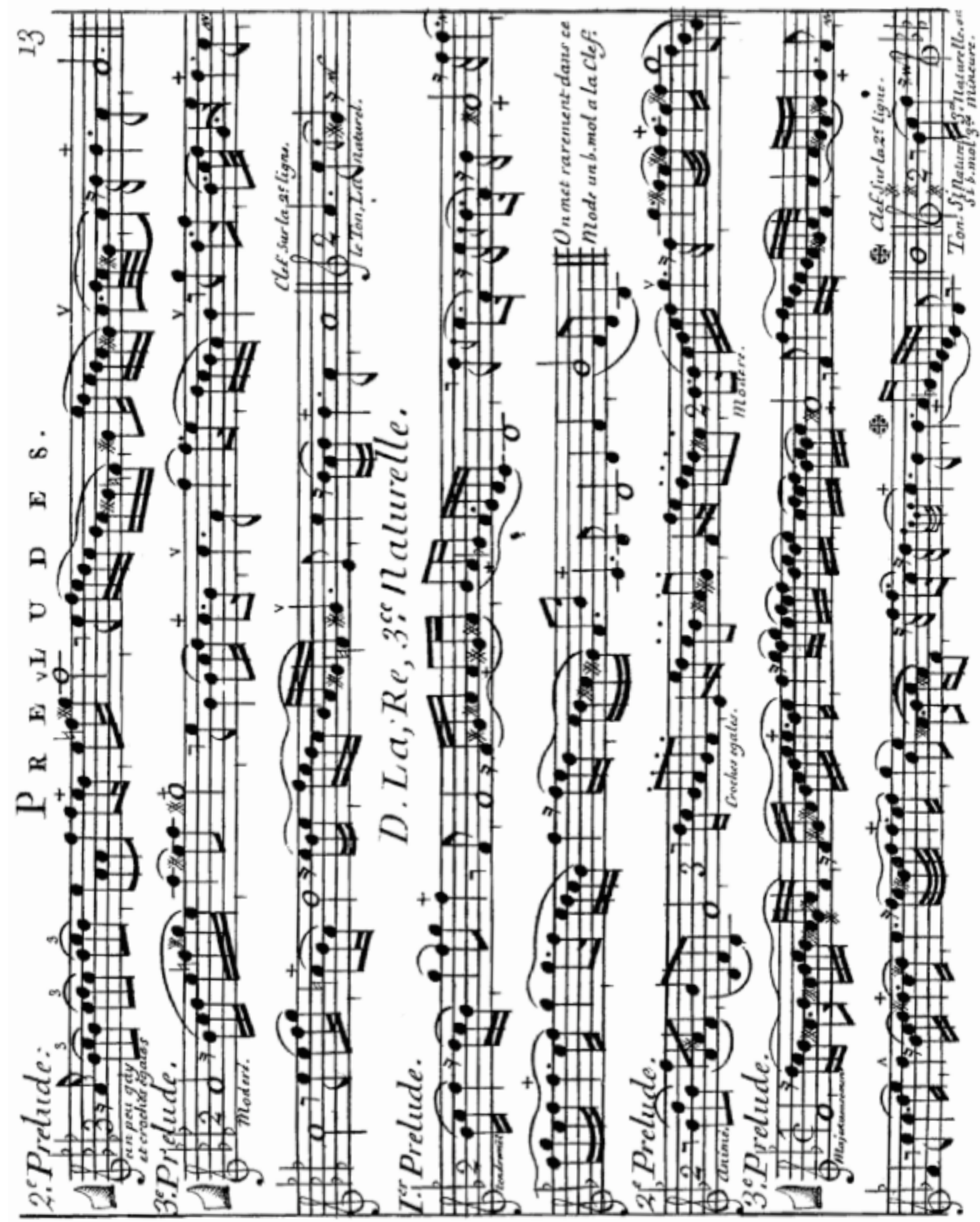

Nesse modo, geralmente, não se coloca um $b$ no lá na armadura de clave. 


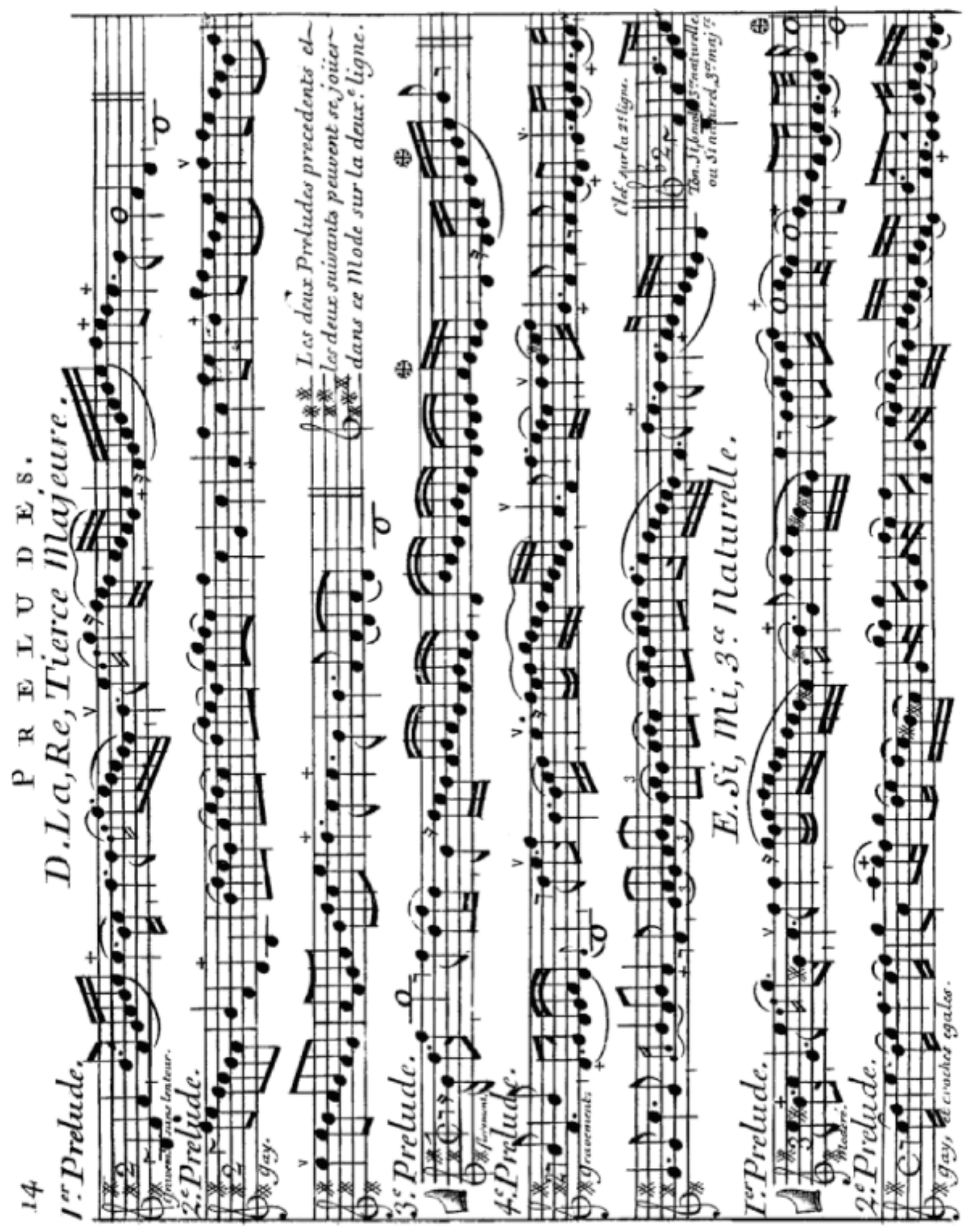




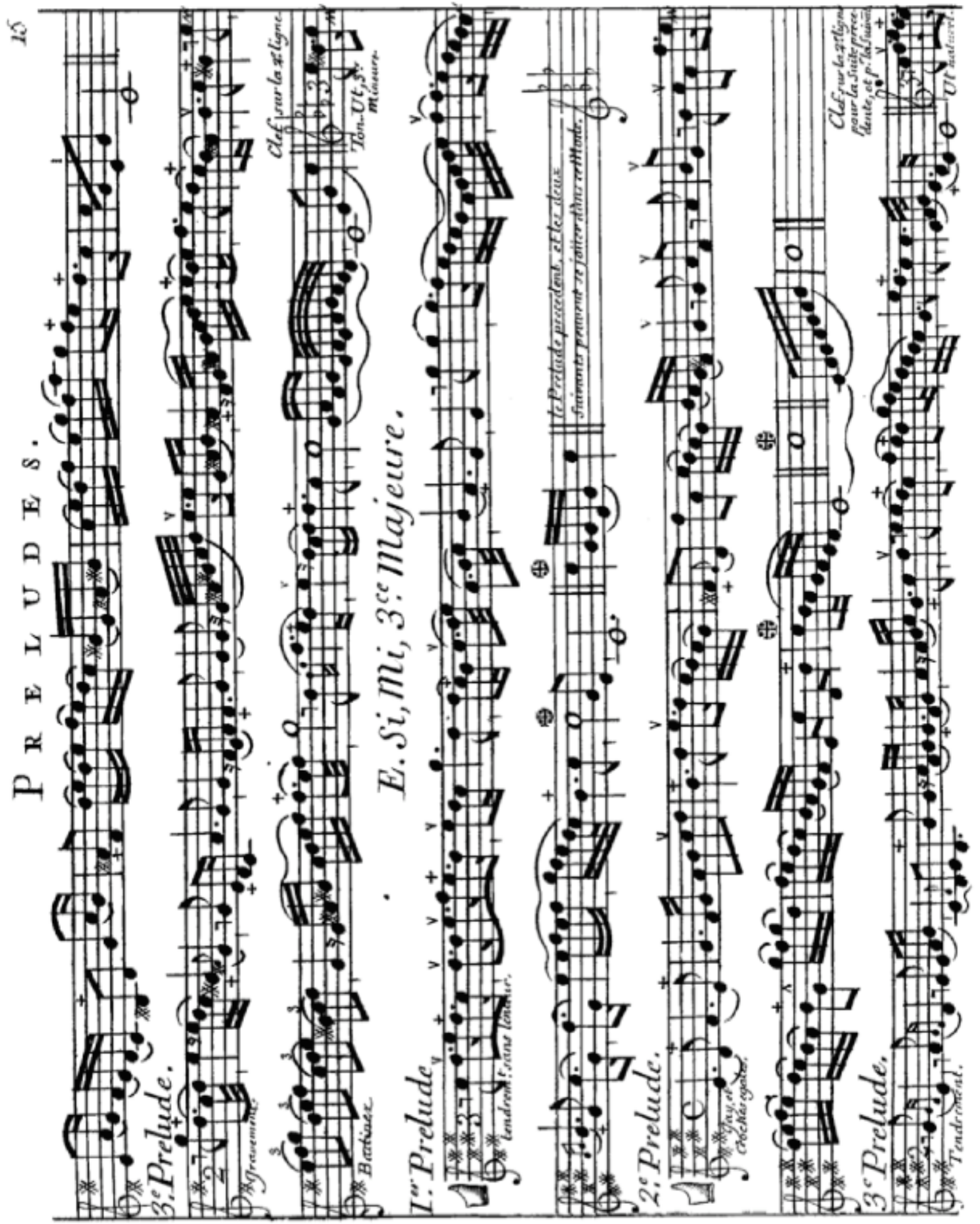

Os dois prelúdios precedentes e os dois seguintes podem ser tocados nesse modo sobre a segunda linha. 


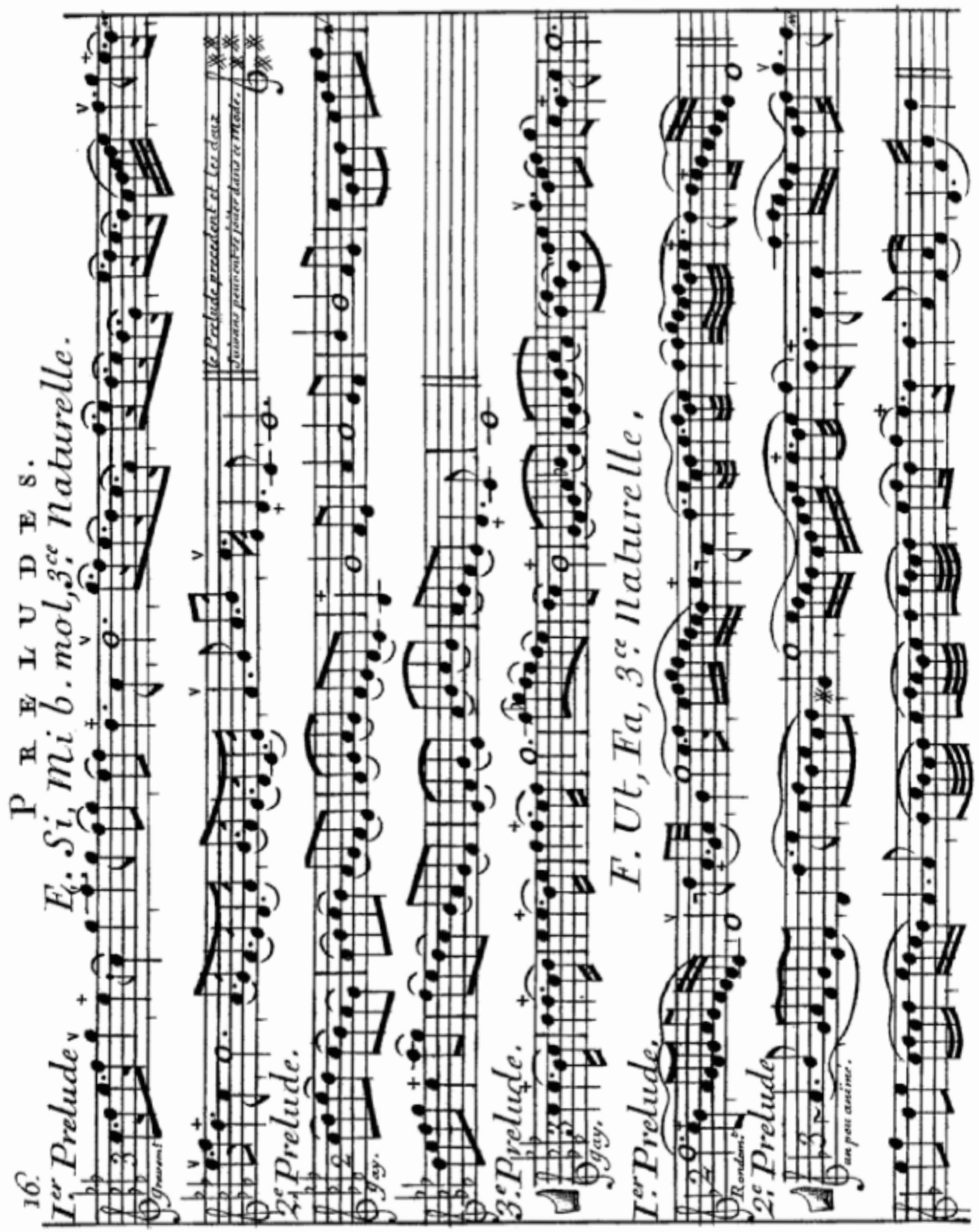




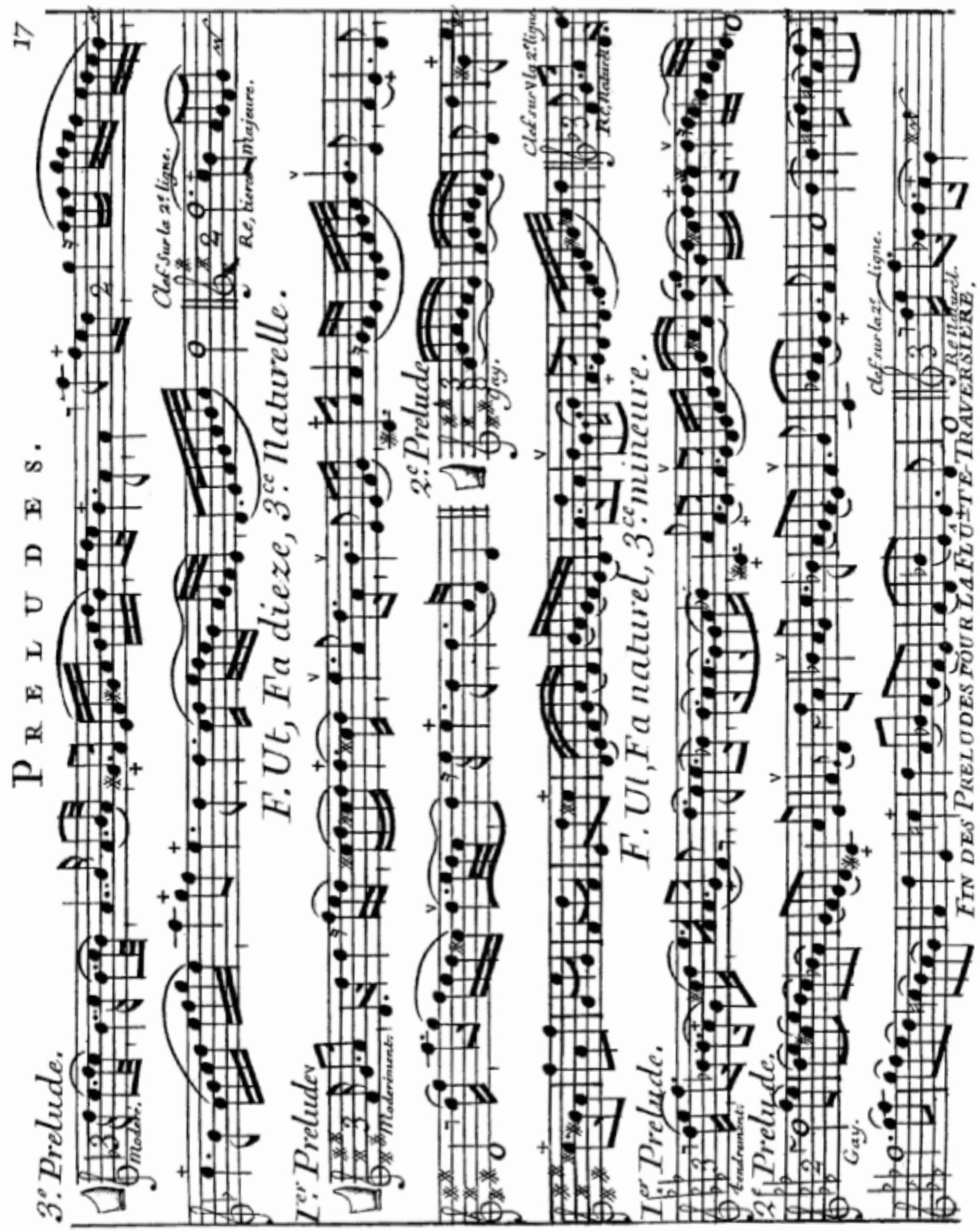




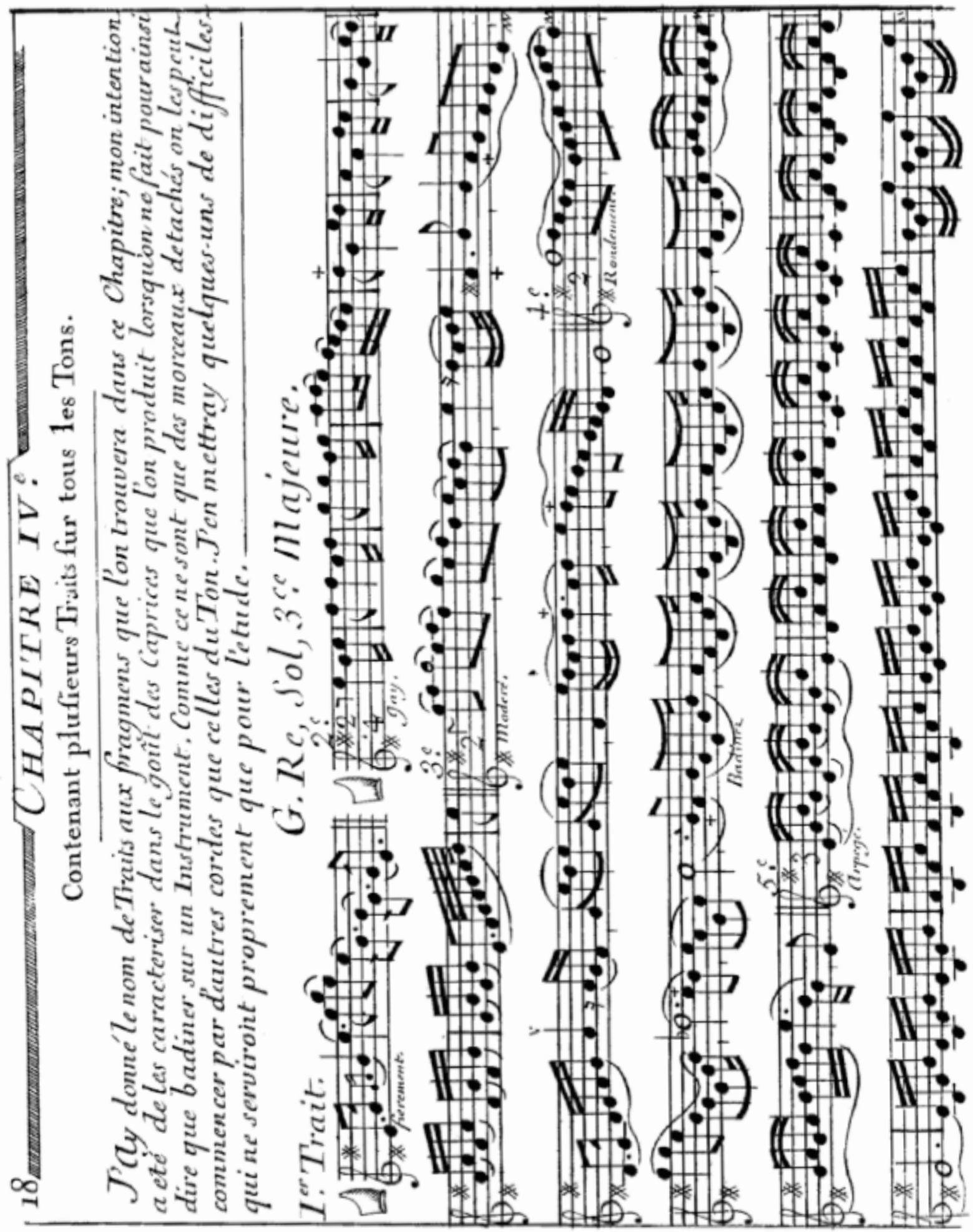




\section{Quarto Capítulo}

\section{Contendo vários traits sobre todos os tons.}

Dei o nome de traits aos fragmentos que serão encontrados neste capítulo; a minha intenção foi caracterizá-los ao gosto dos caprichos $^{213}$ que são produzidos quando se faz, por assim dizer, apenas brincar sobre um instrumento musical. Como são apenas pedaços destacados, pode-se começá-lo por outras cordas que não sejam aquelas do tom.

Colocarei alguns exemplos difíceis que servirão unicamente para o estudo.

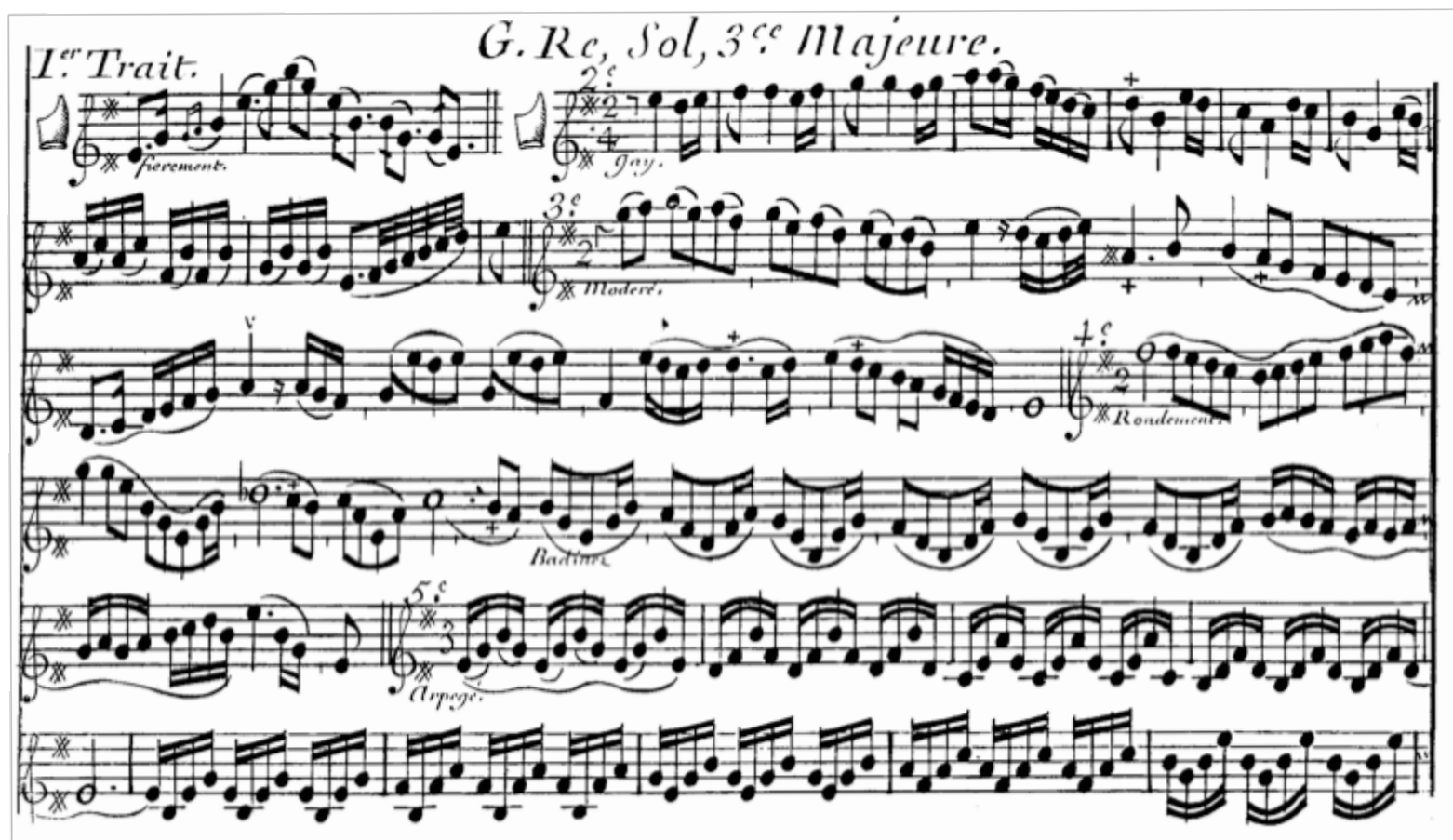

213 A expressão "goût des Caprices" [gosto dos caprichos] utilizada por Hotteterre é exposta no terceiro capítulo deste trabalho. 


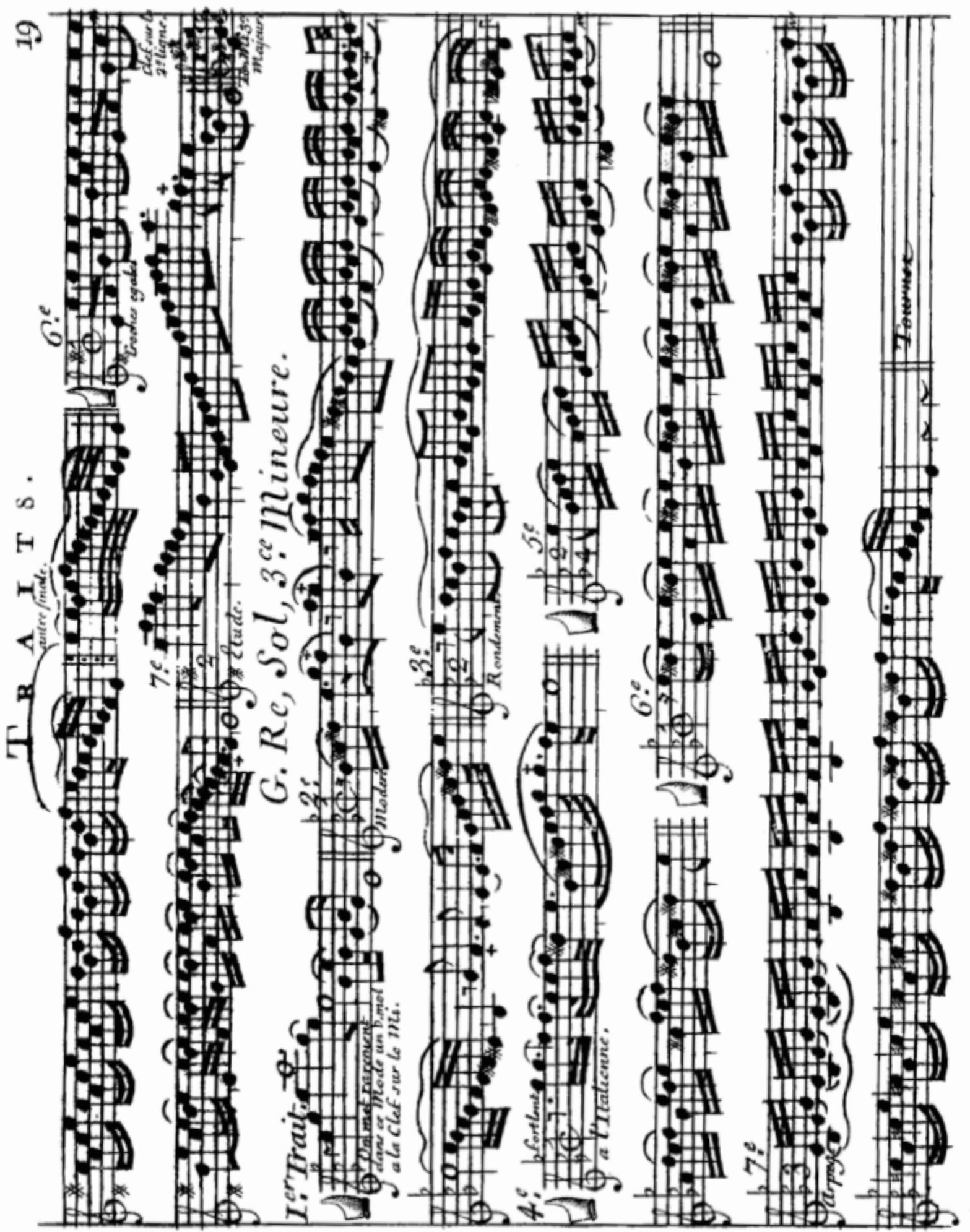




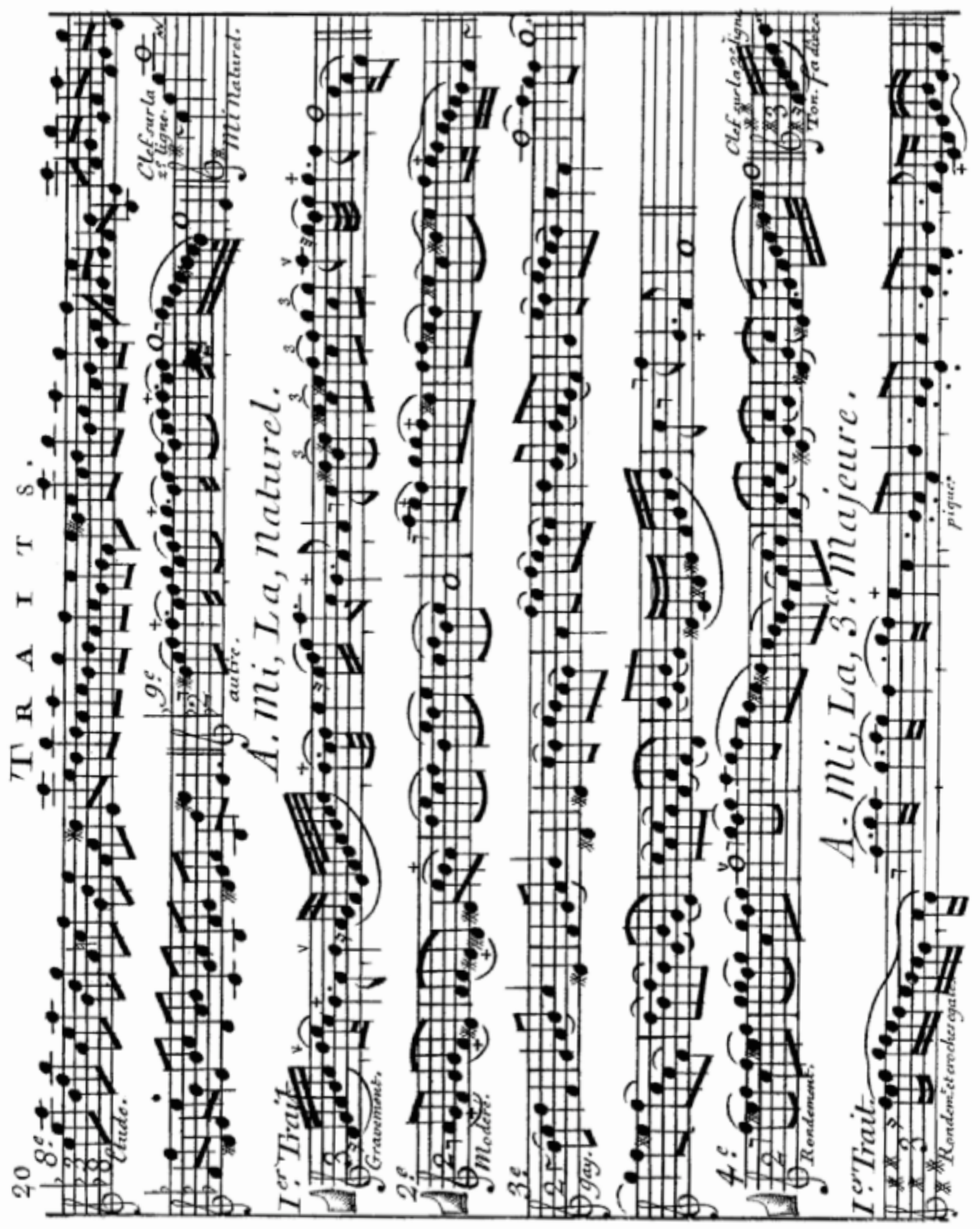




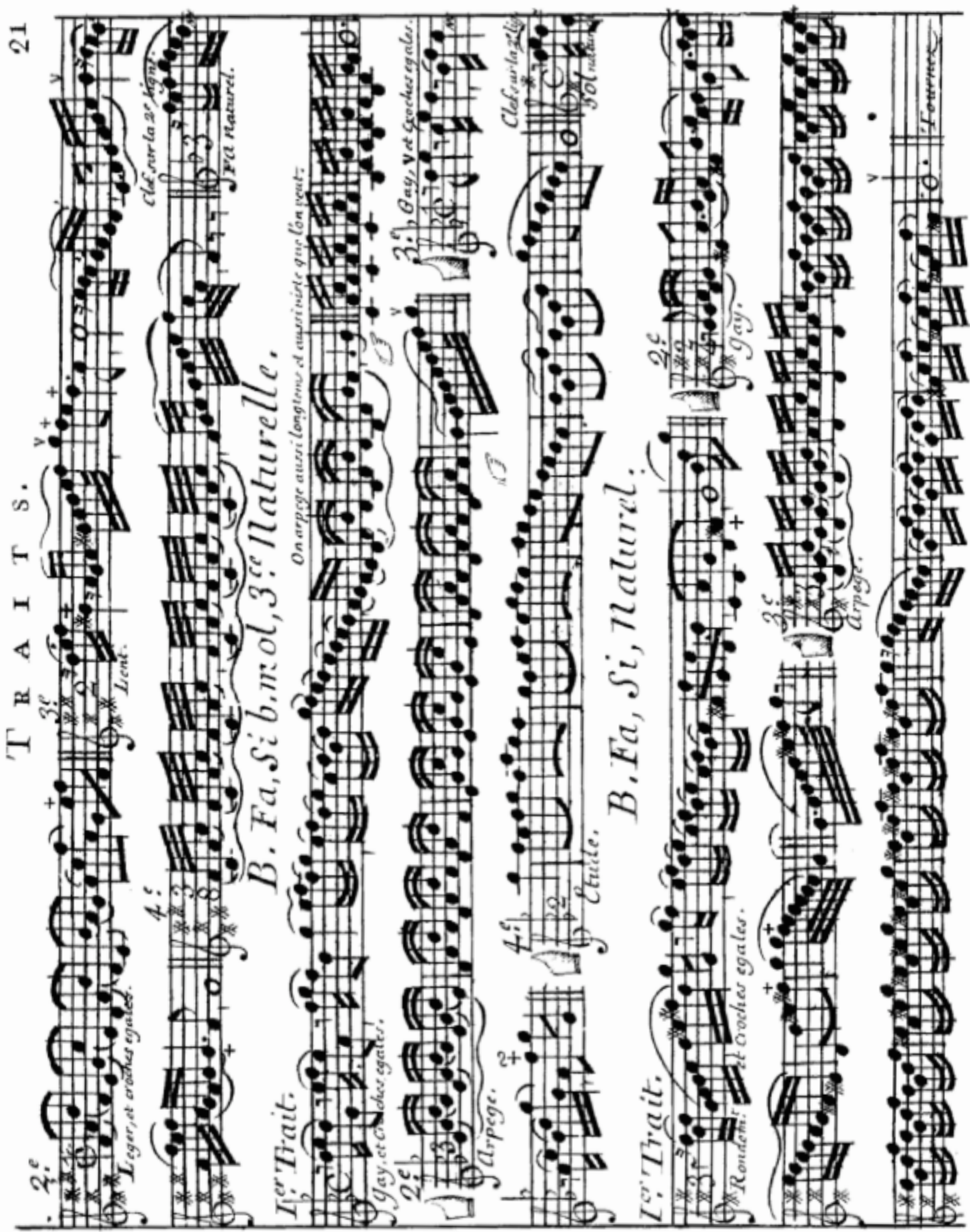




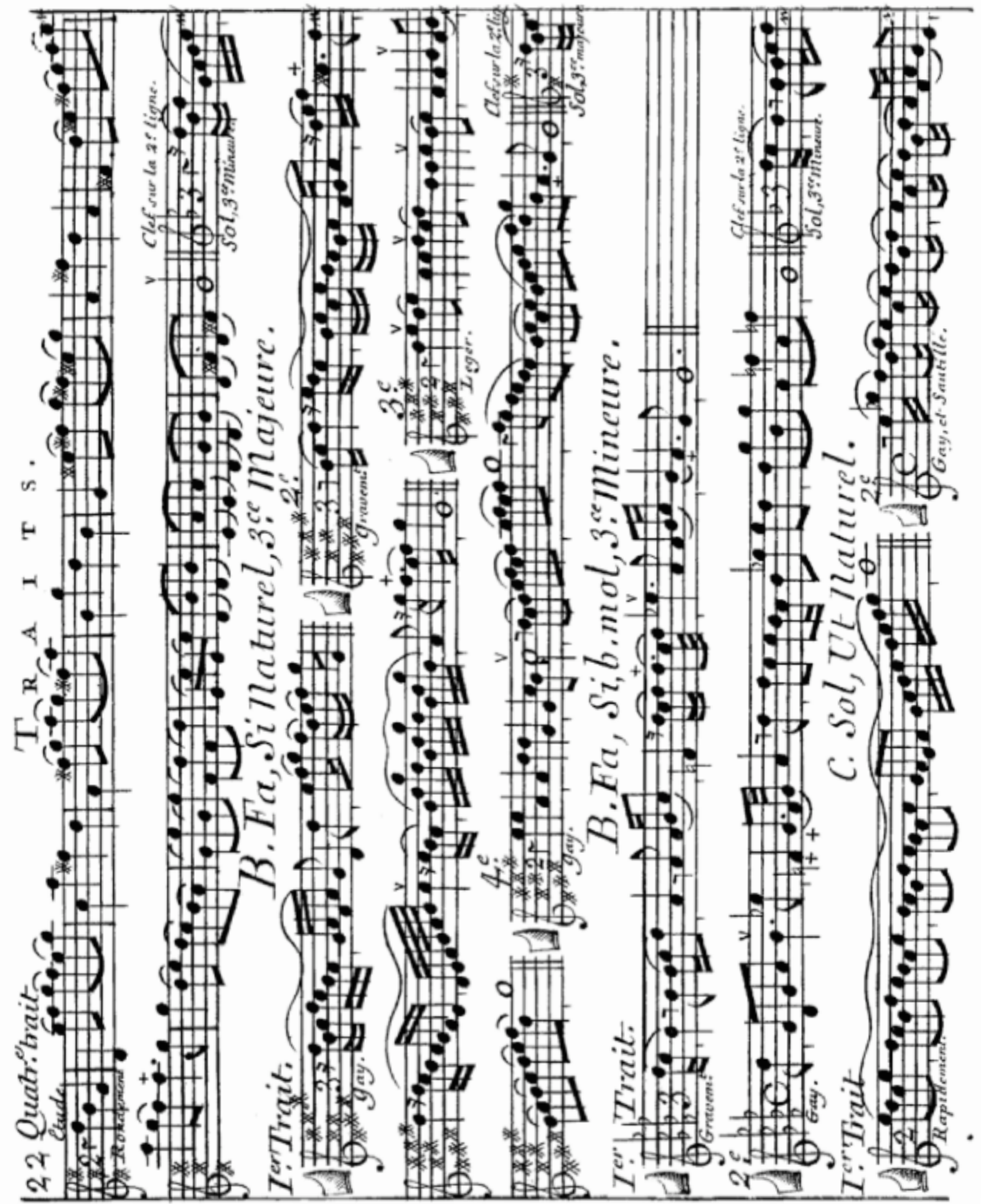




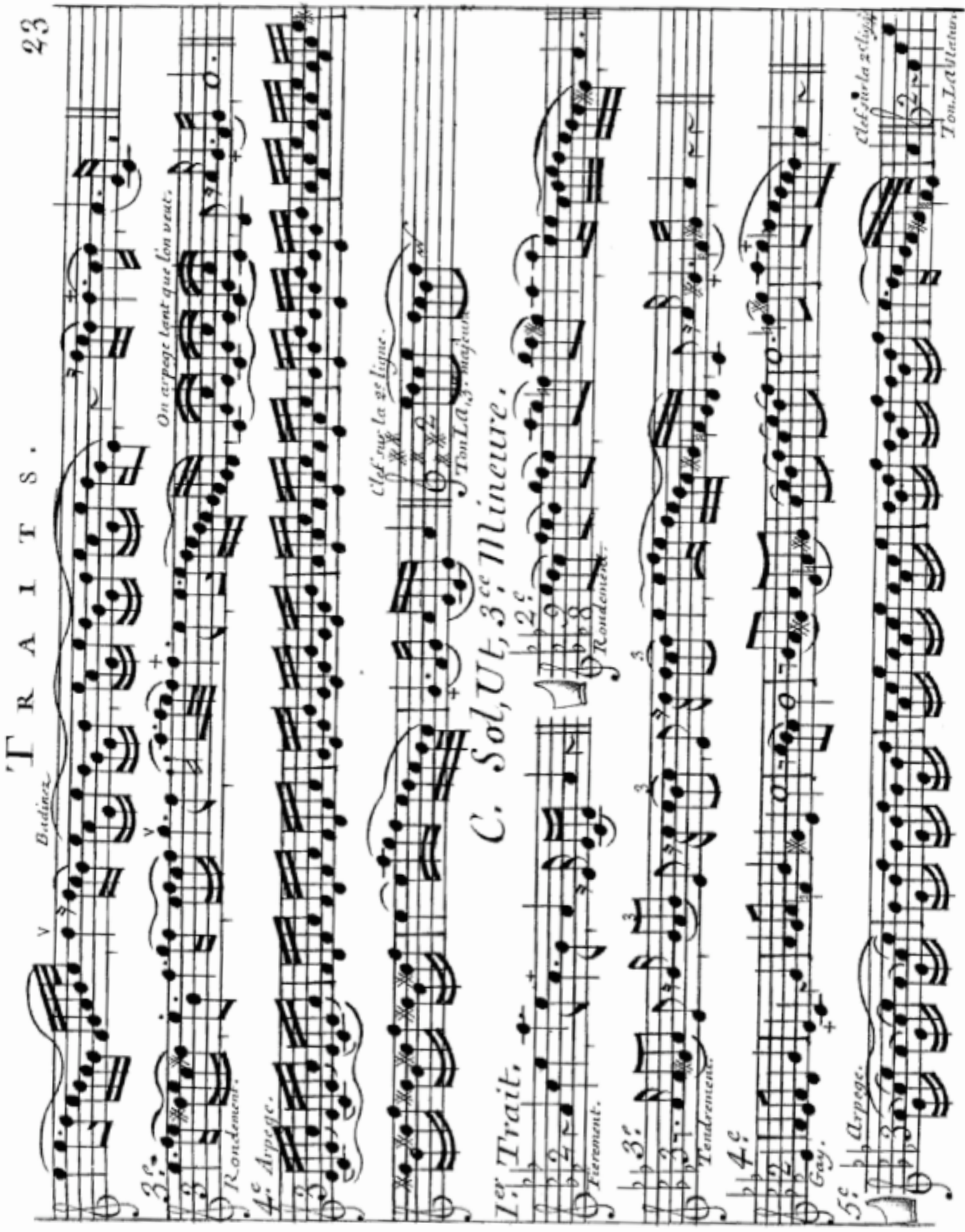




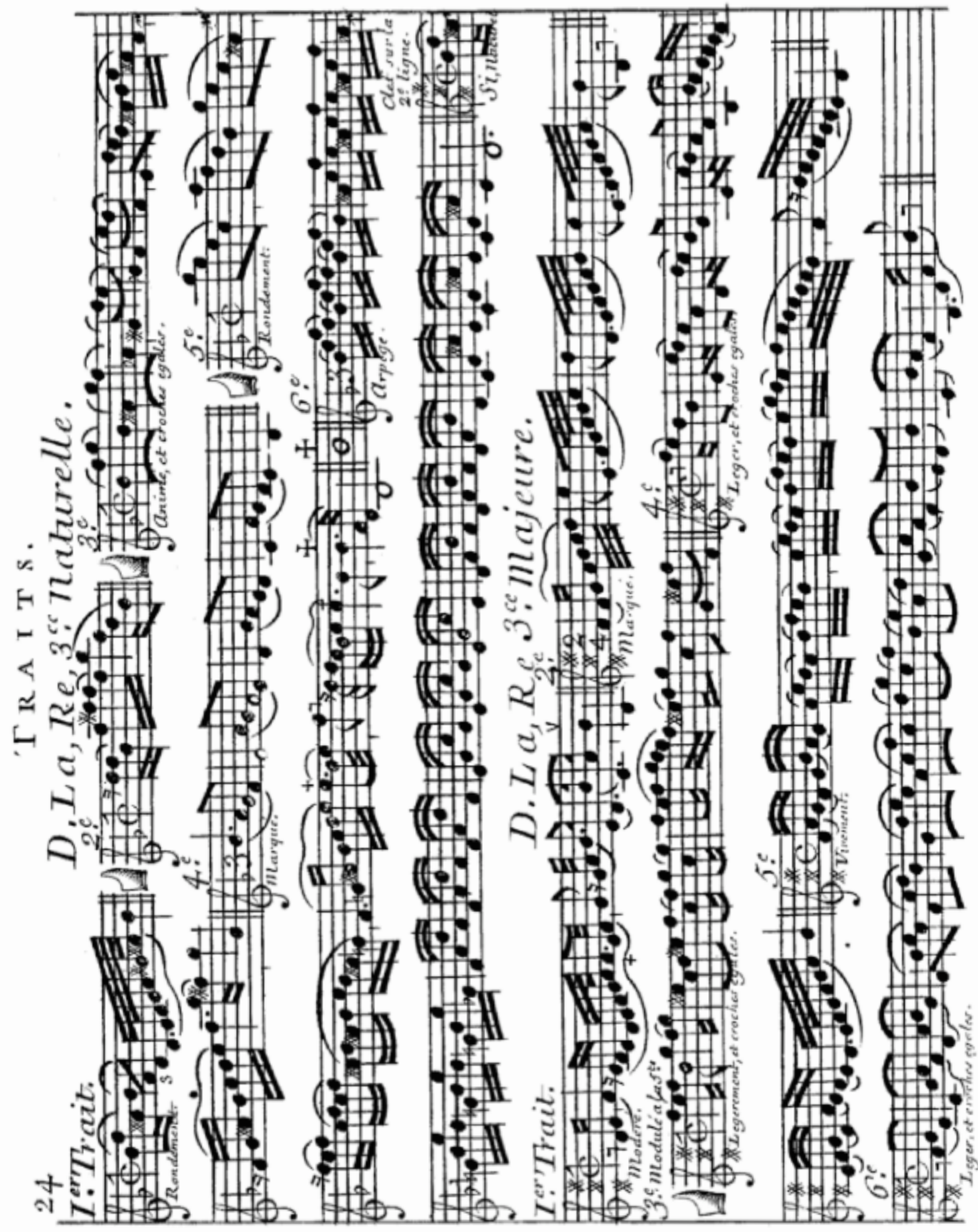




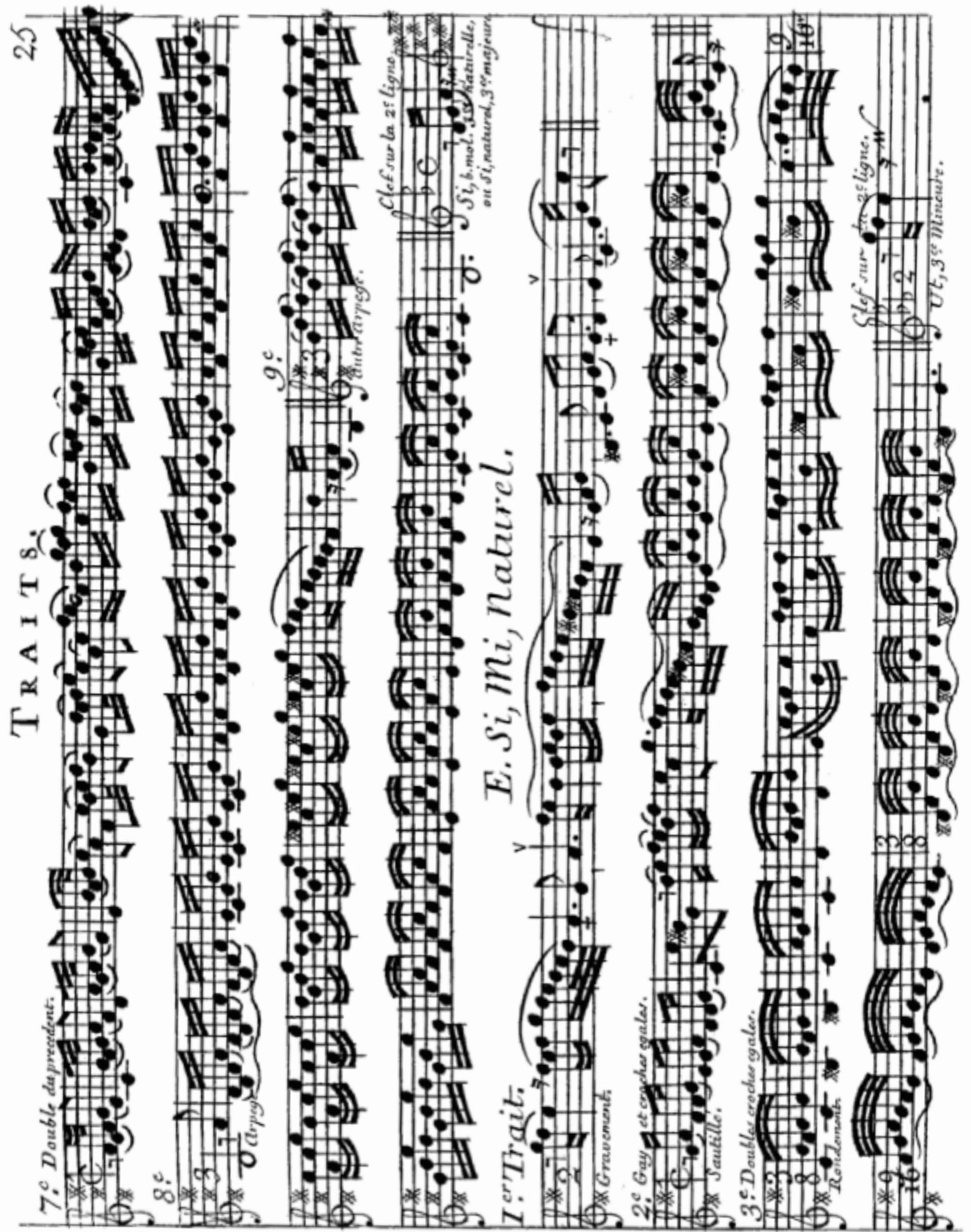




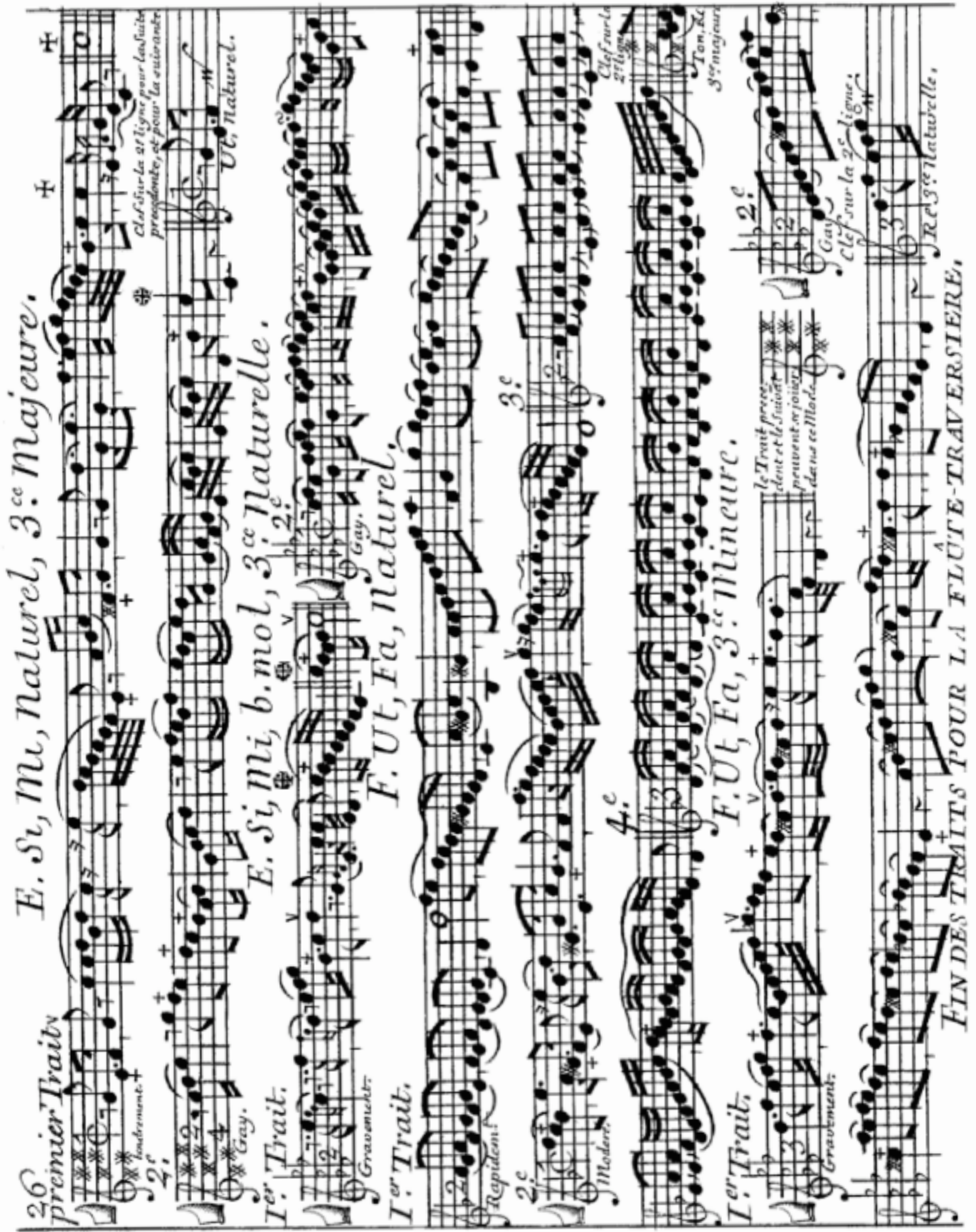




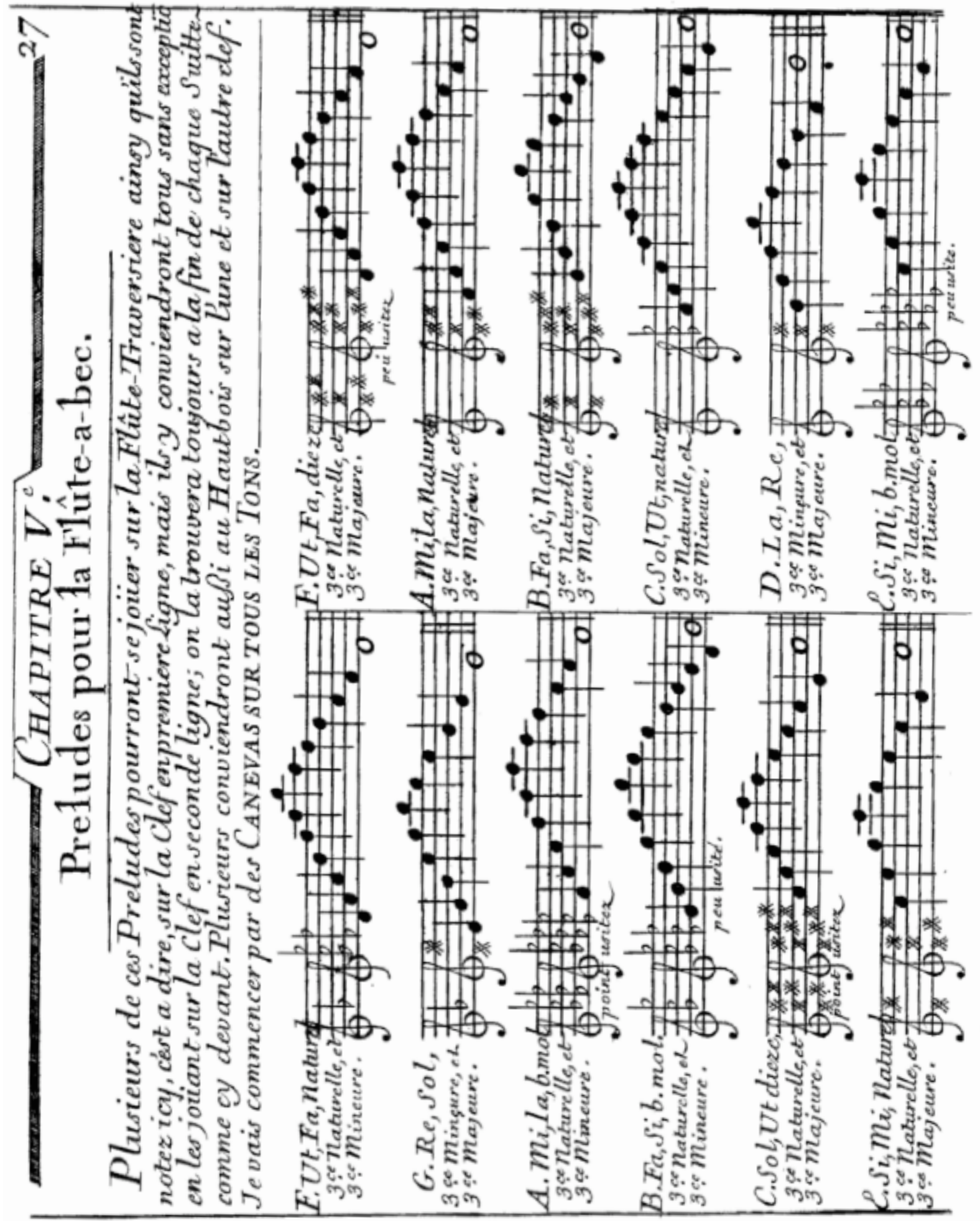




\section{Quinto Capítulo}

\section{Prelúdios para flauta doce}

Vários destes prelúdios poderão ser tocados na flauta traversa, da forma como são notados aqui, ou seja, sobre a clave na primeira linha; mas todos eles, sem exceção, poderão ser convenientes ${ }^{214}$ quando tocados sobre a clave em segunda linha, que se encontrará sempre no fim de cada sequência, como anteriormente. Vários servirão também para o oboé sobre uma ou outra clave.

Vou começar pelos CANEVAS SOBRE TODOS OS TONS.

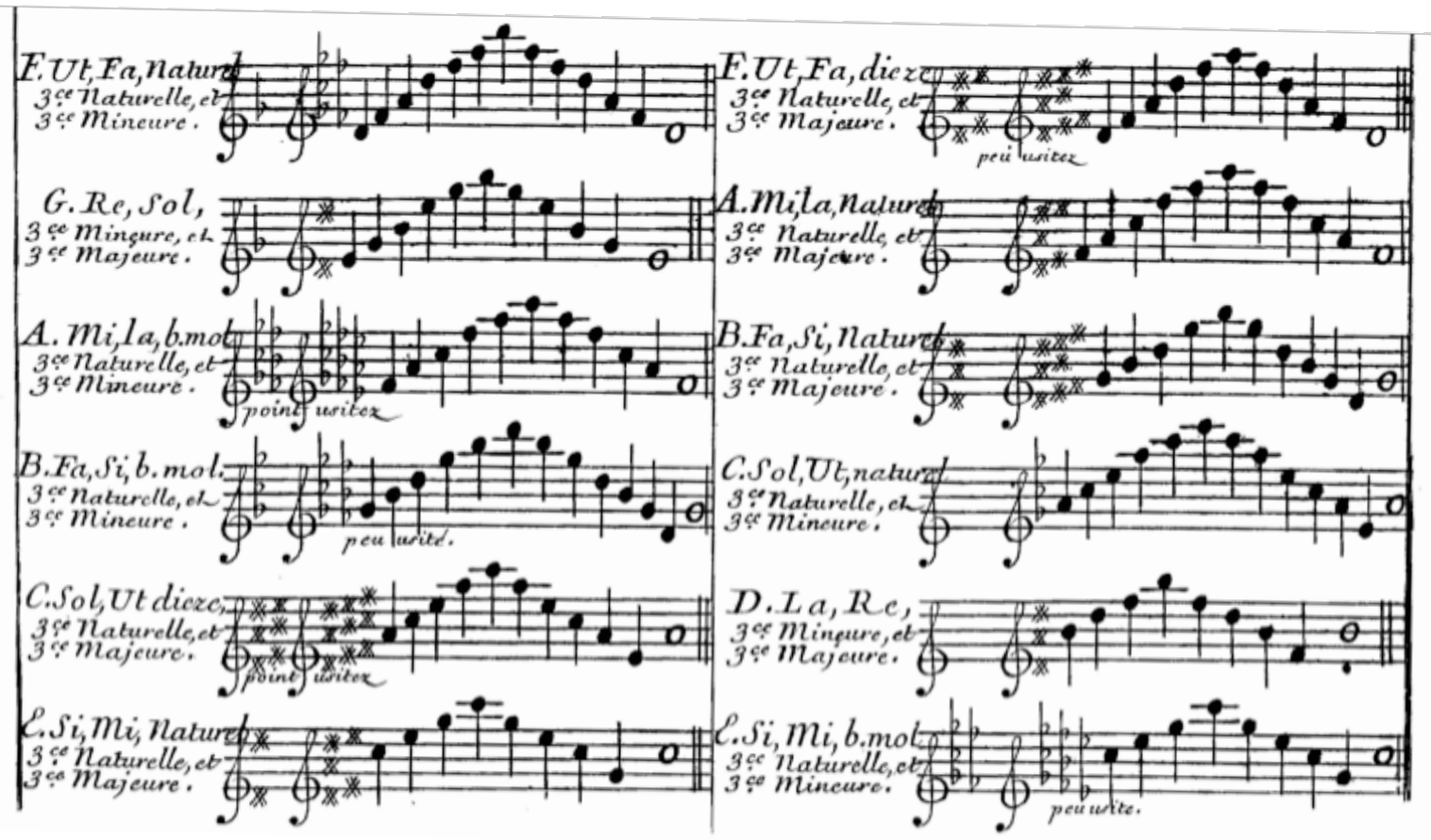

${ }^{214}$ O verbo convenir significa apropriado, adequado, ou seja, se refere a um tipo de decoro. Sobre o caráter 'adequado' (convenant), Molinié afirma que é essencial em retórica. Esse é um ponto considerado moral, social e técnico. A conveniência moral faz com que o orador, na escolha da causa, na orientação do seu discurso, no conteúdo, nos seus termos, nos seus meios controvertidos, na sua ação, respeite escrupulosamente a equidade, a justiça e a honestidade. A conveniência social diz respeito às pessoas que falam e às pessoas a quem se dirige a fala; é uma moderação da boa educação, ou mesmo delicadeza, no conjunto do comportamento oratório. A conveniência técnica, por último, obriga incessante e sistematicamente a adaptar o tom, o andamento, os métodos e o desenvolvimento do discurso à natureza da causa, e todas as circunstâncias do assunto proposto. In: MOLINIÉ, G. Op. cit., p. 92. 


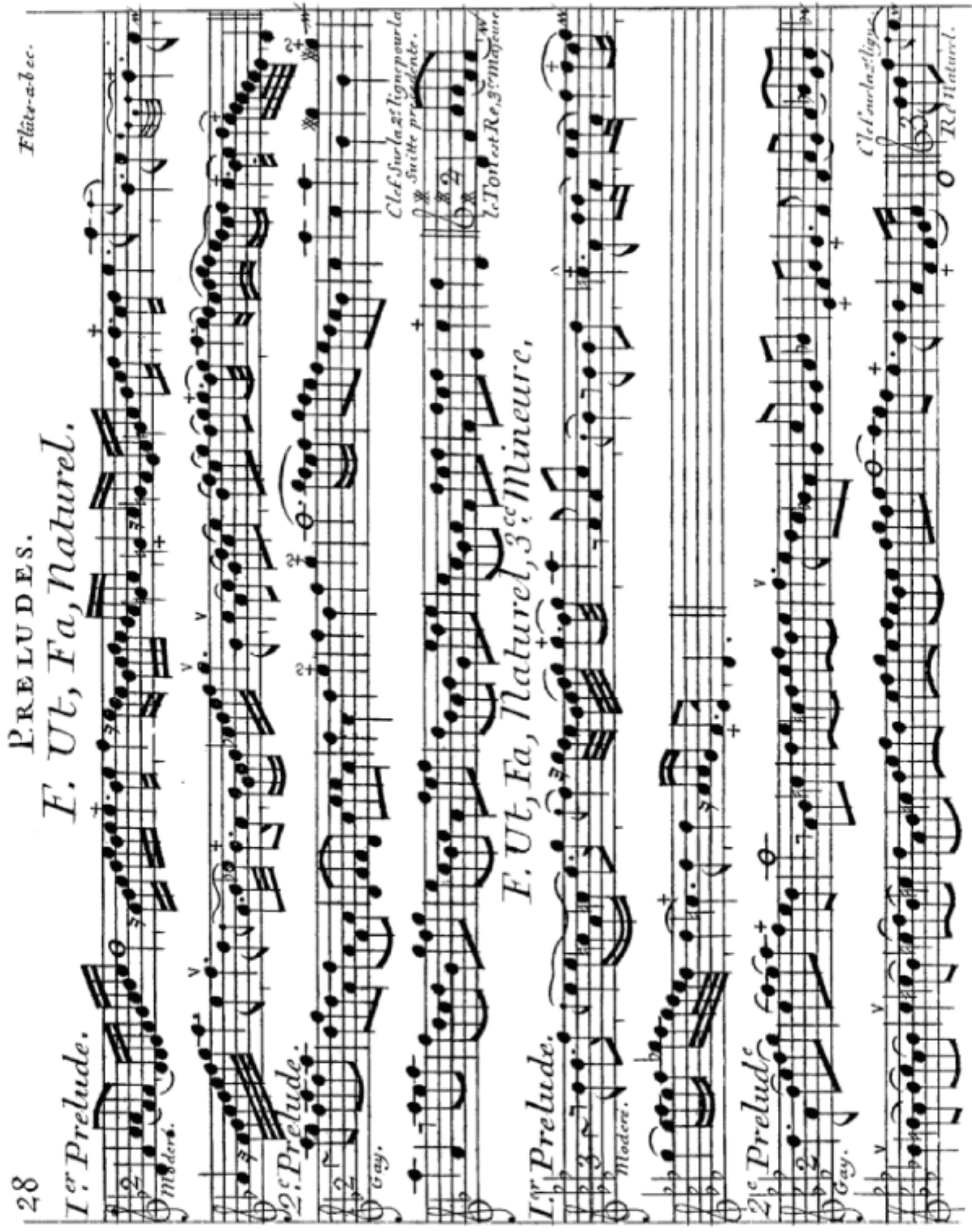




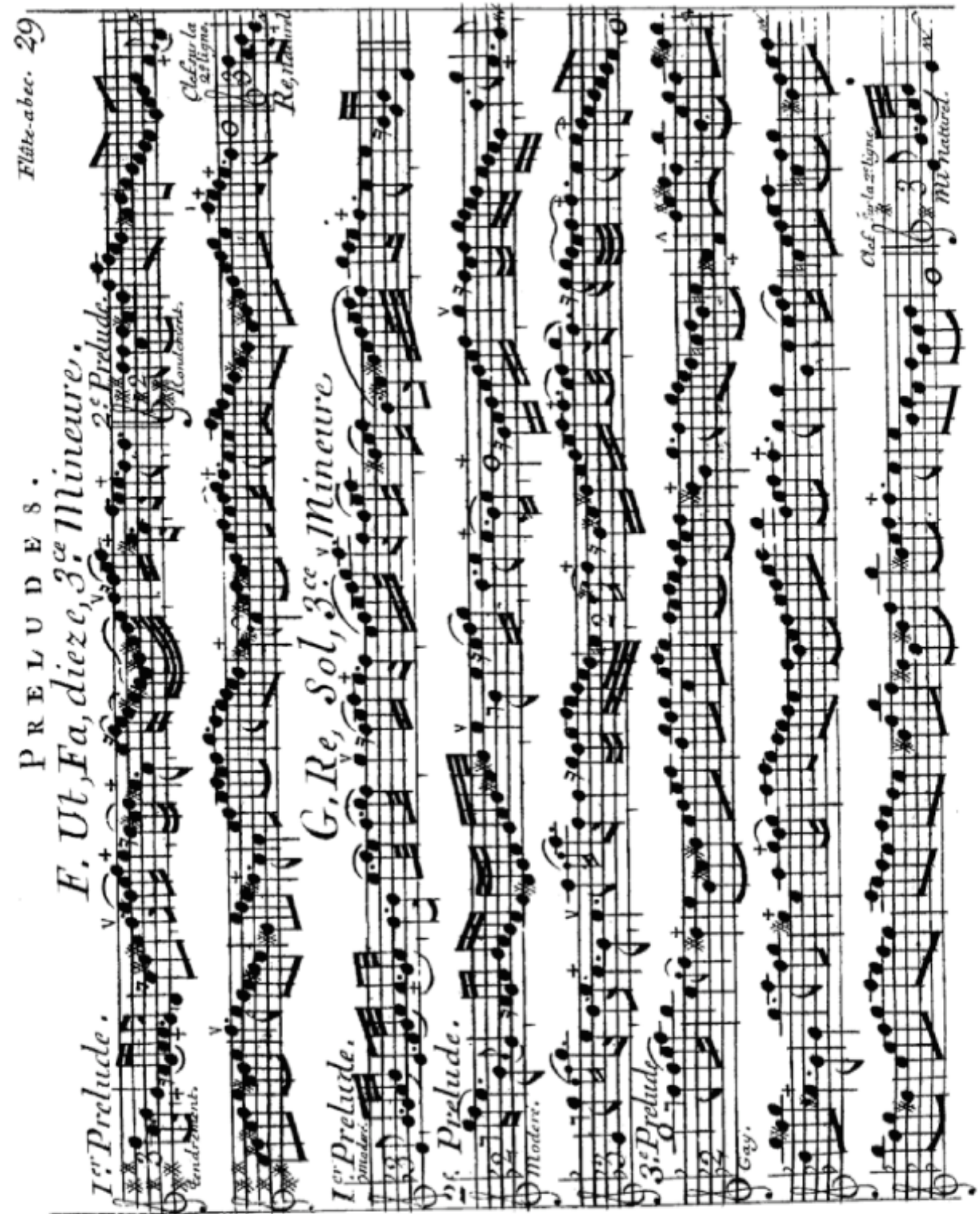




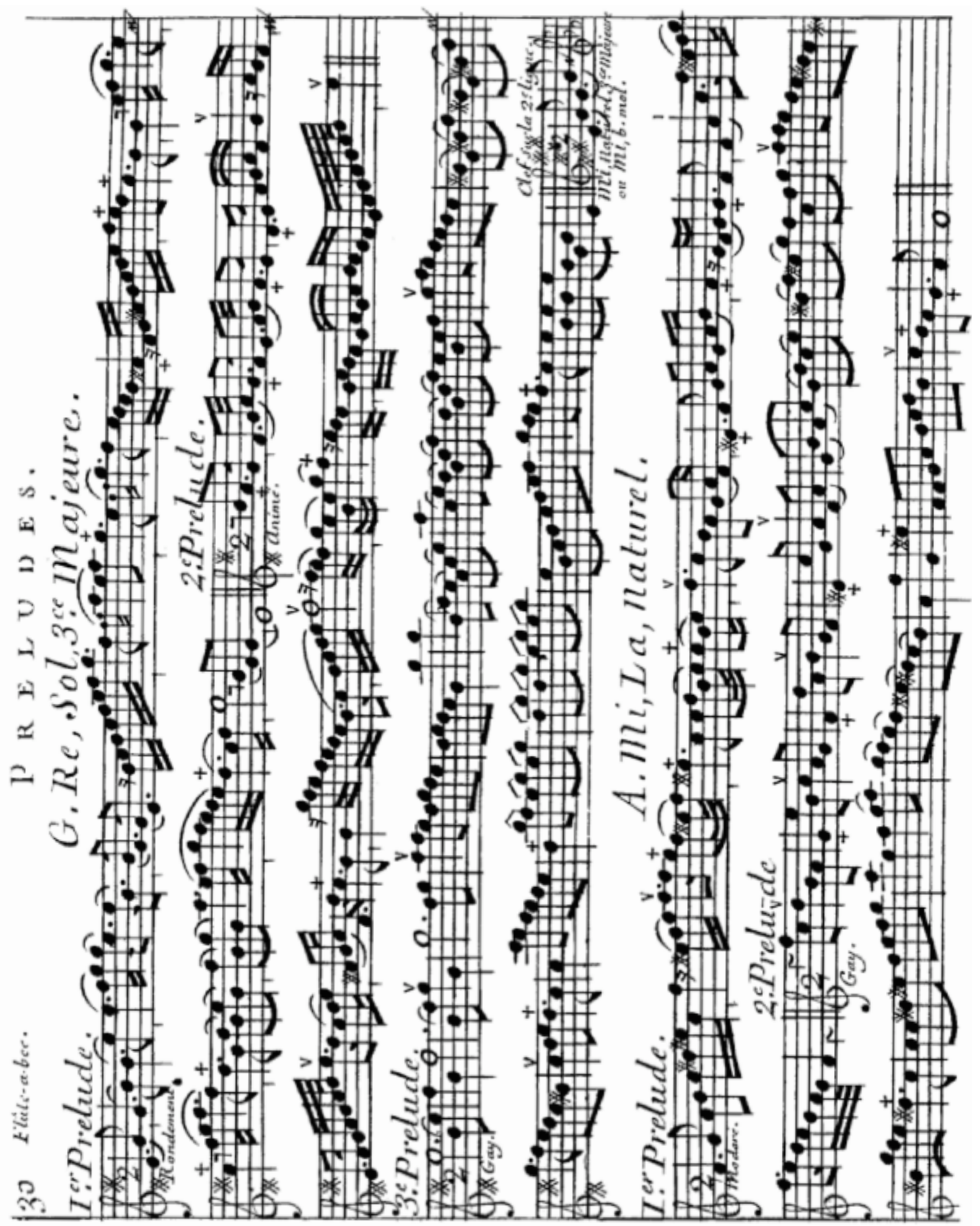




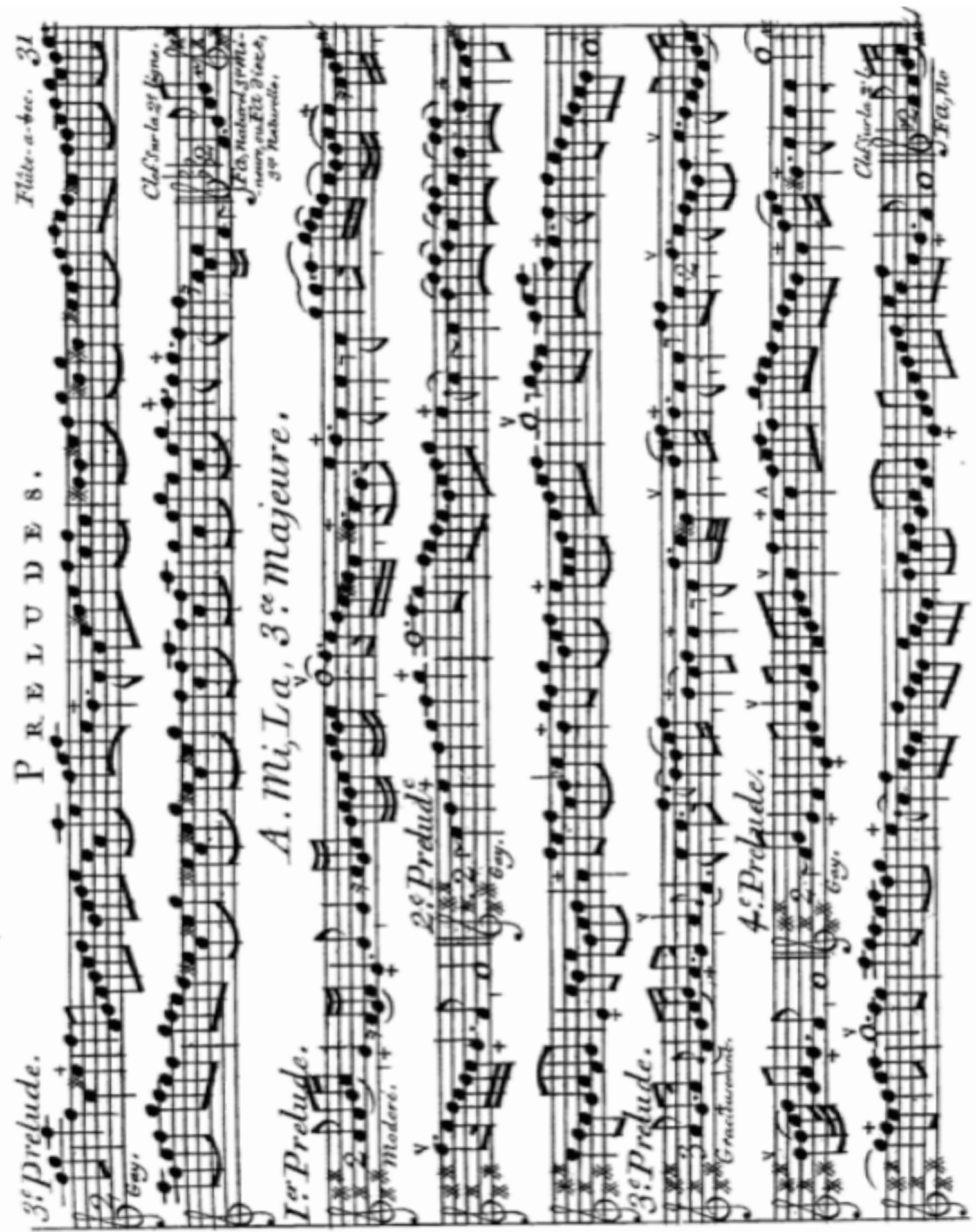




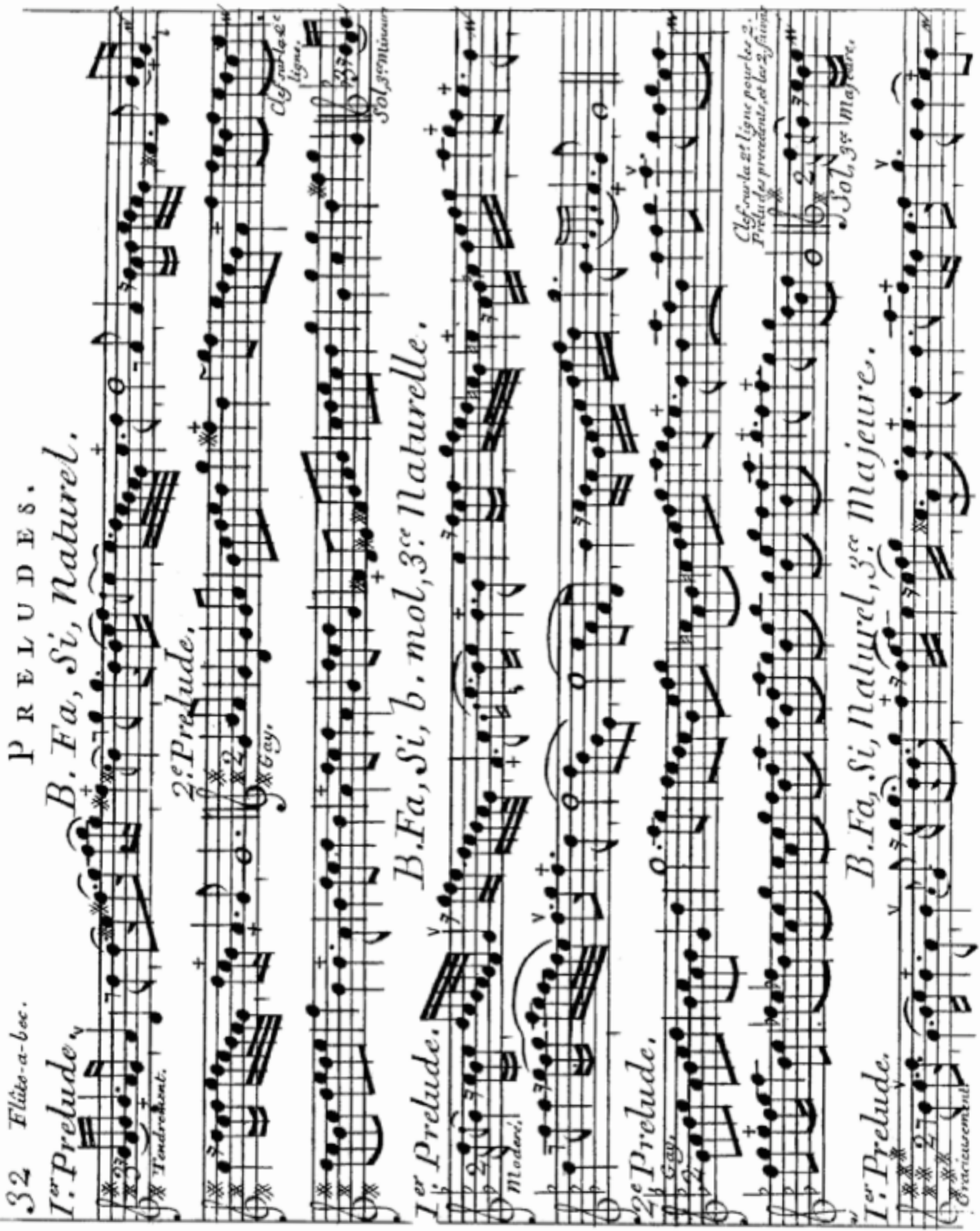




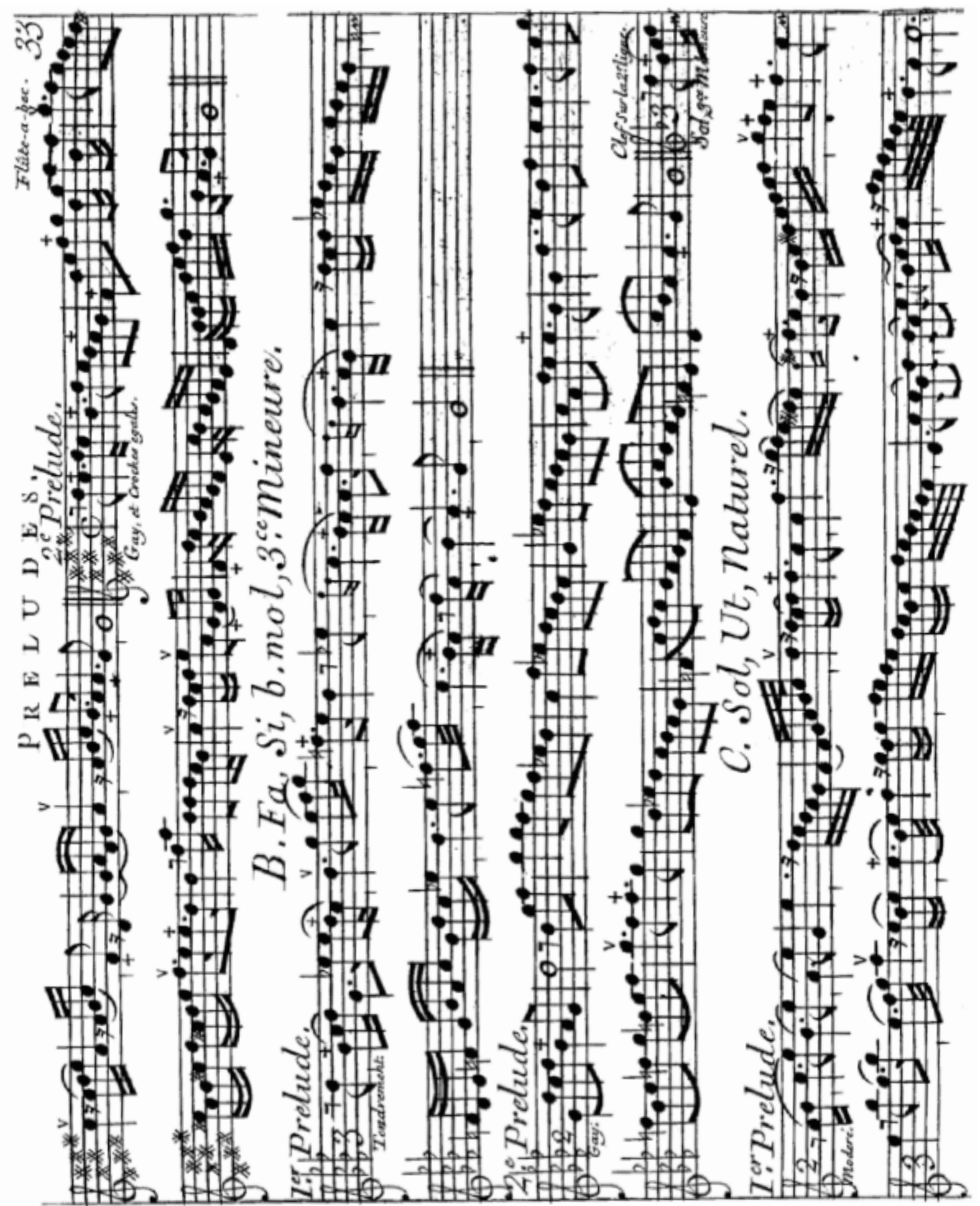




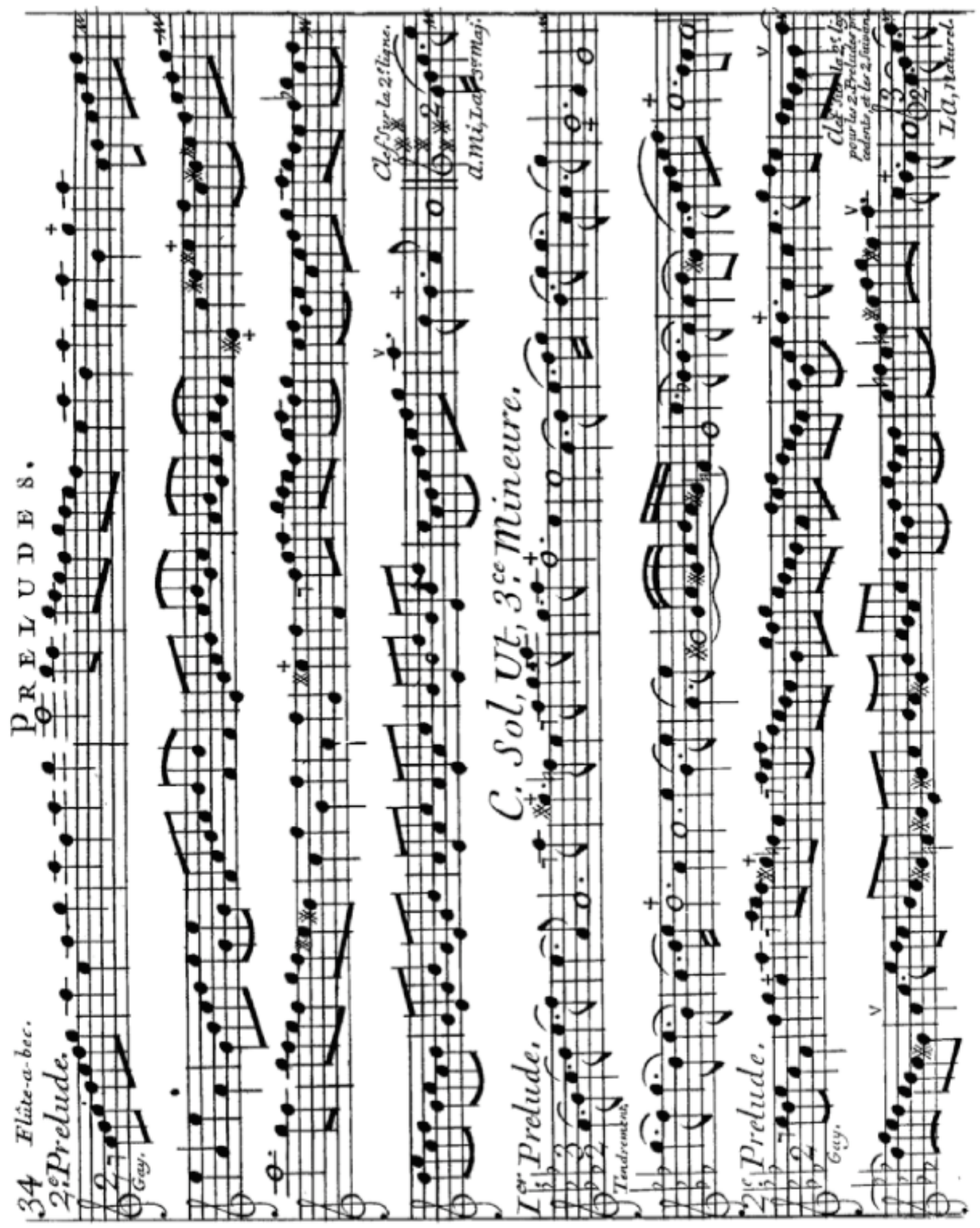




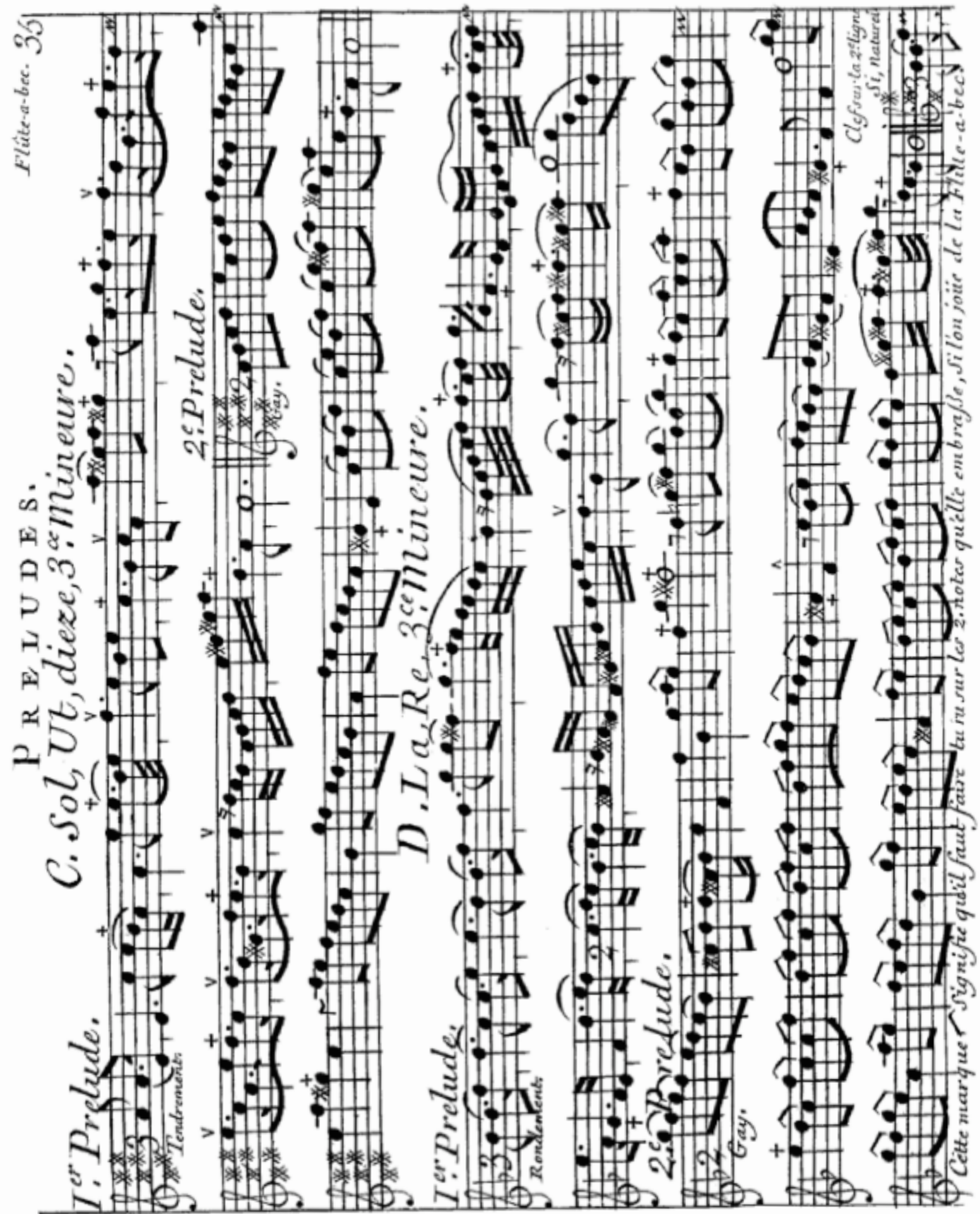

Esta marca significa que é necessário fazer $\boldsymbol{T} \boldsymbol{u} \boldsymbol{R} \boldsymbol{u}$ sobre as duas notas que ela abraça, quando são tocadas na flauta doce. 


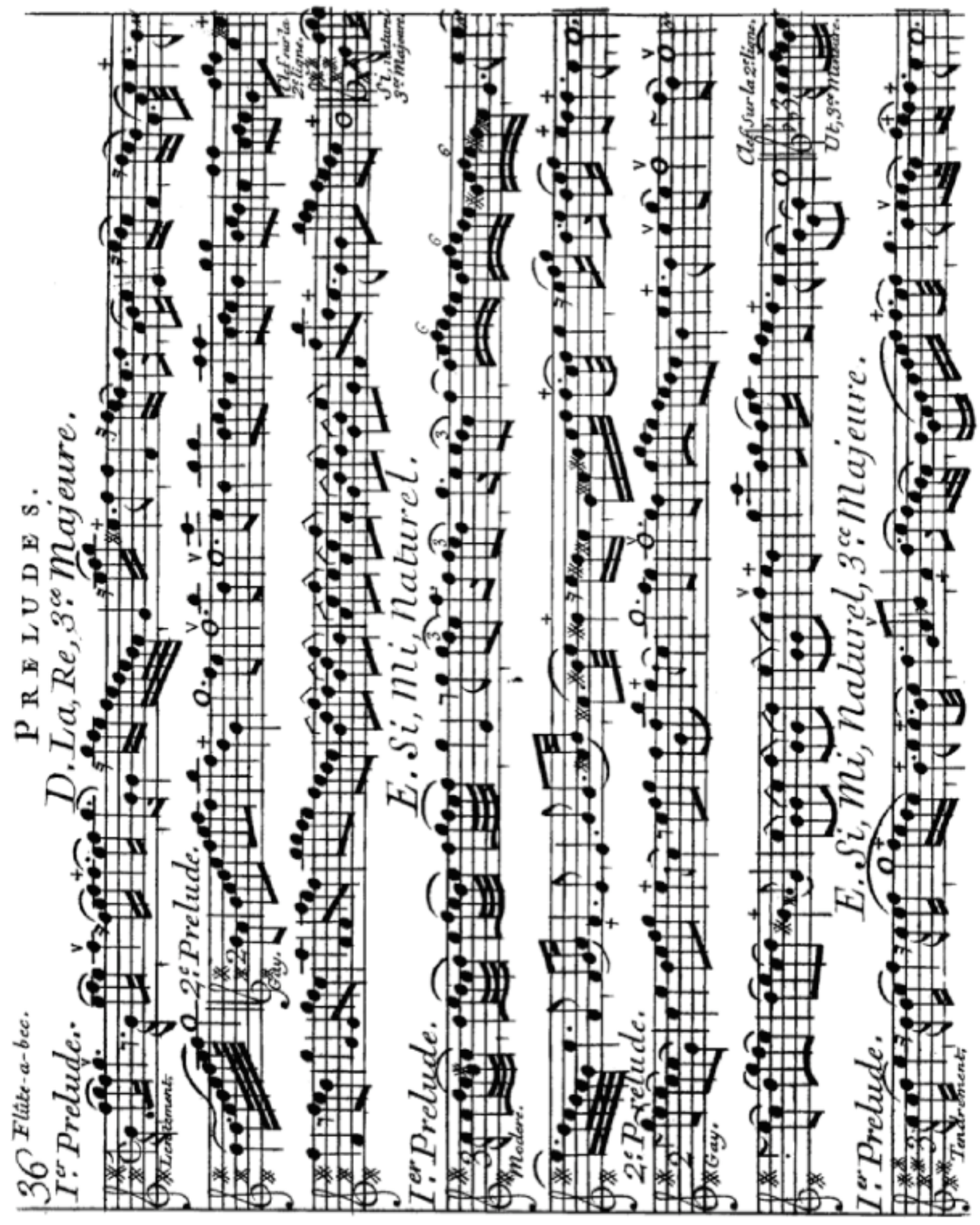




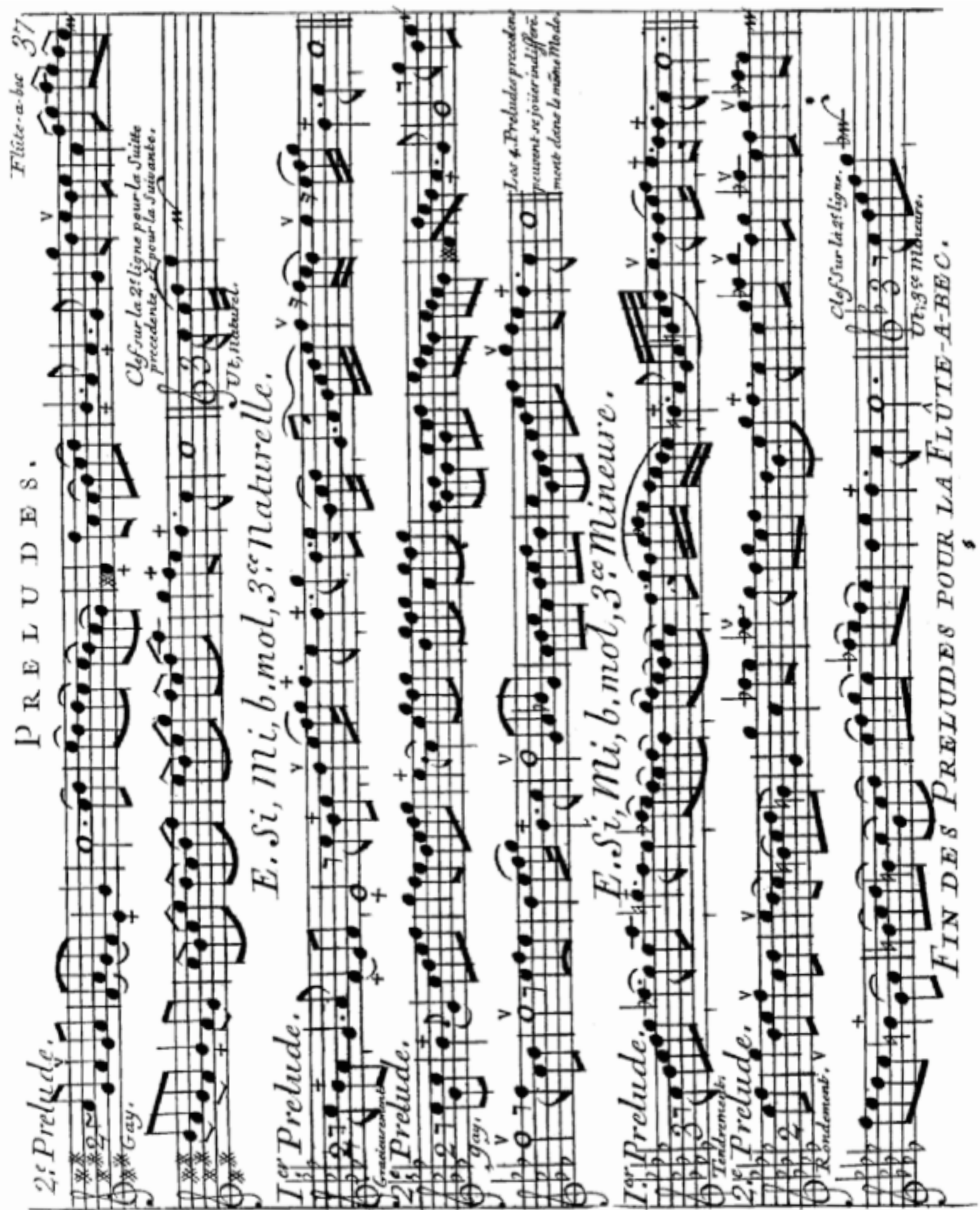

Fim dos prelúdios para a flauta doce 


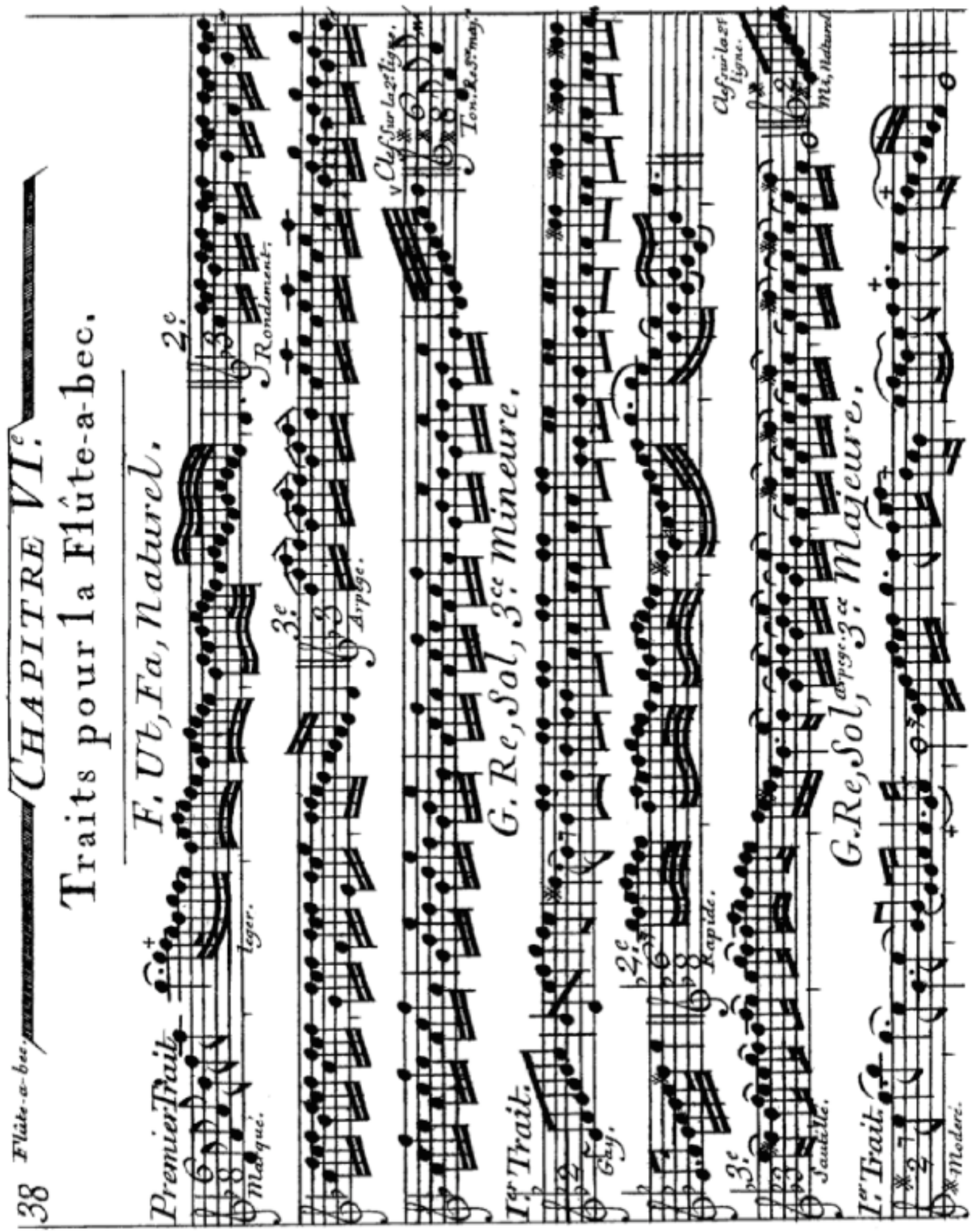


Sexto Capítulo

Traits para a flauta doce 


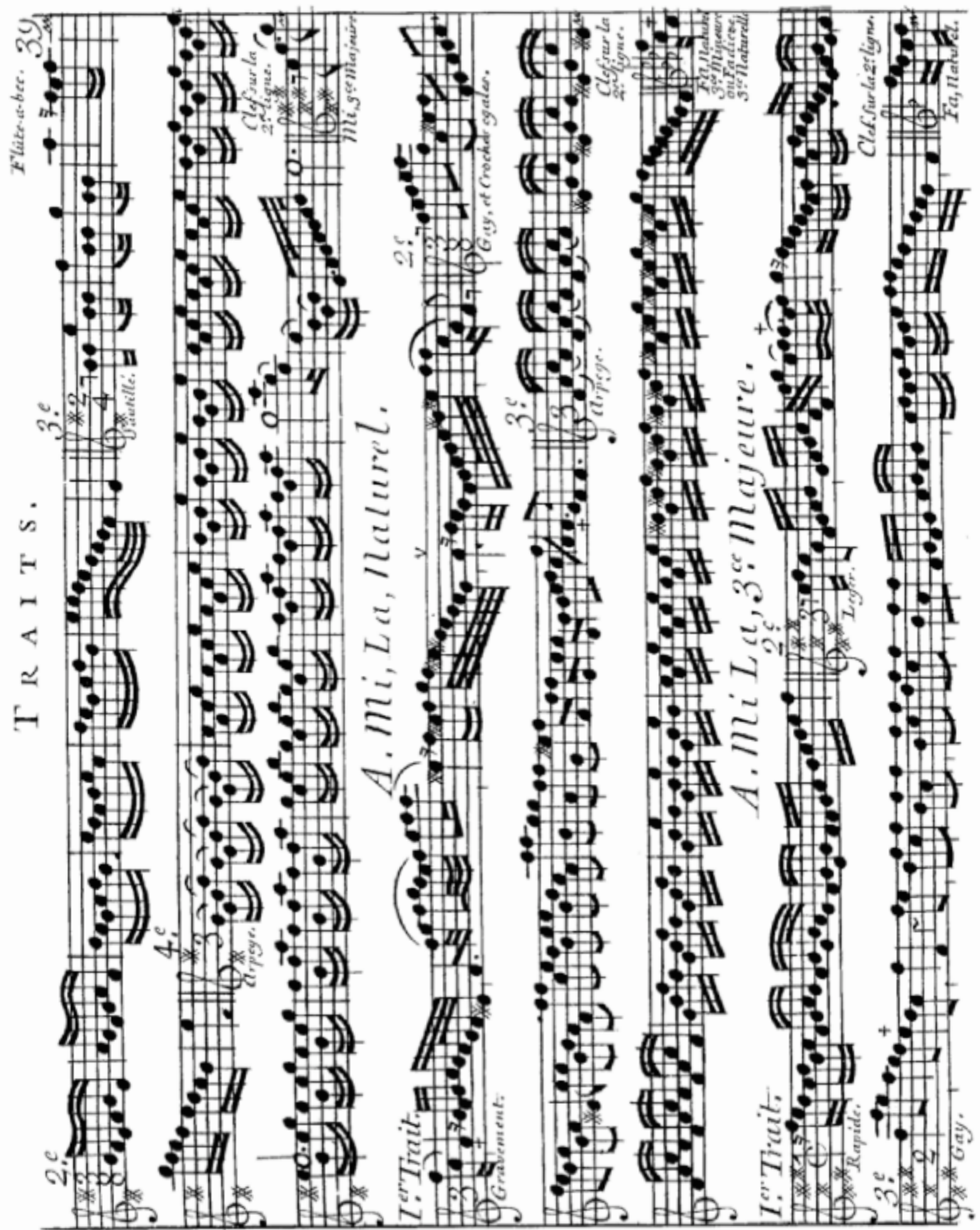




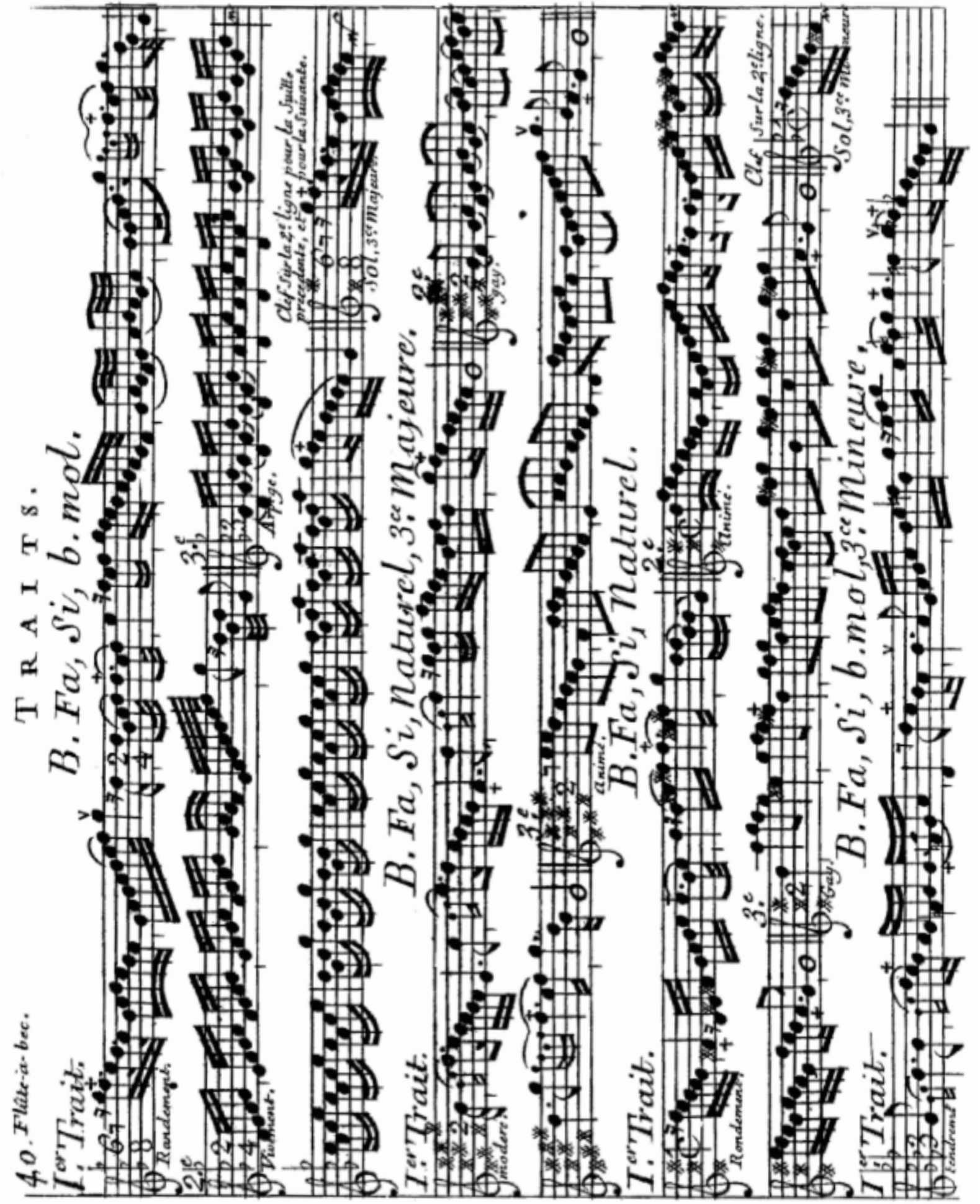




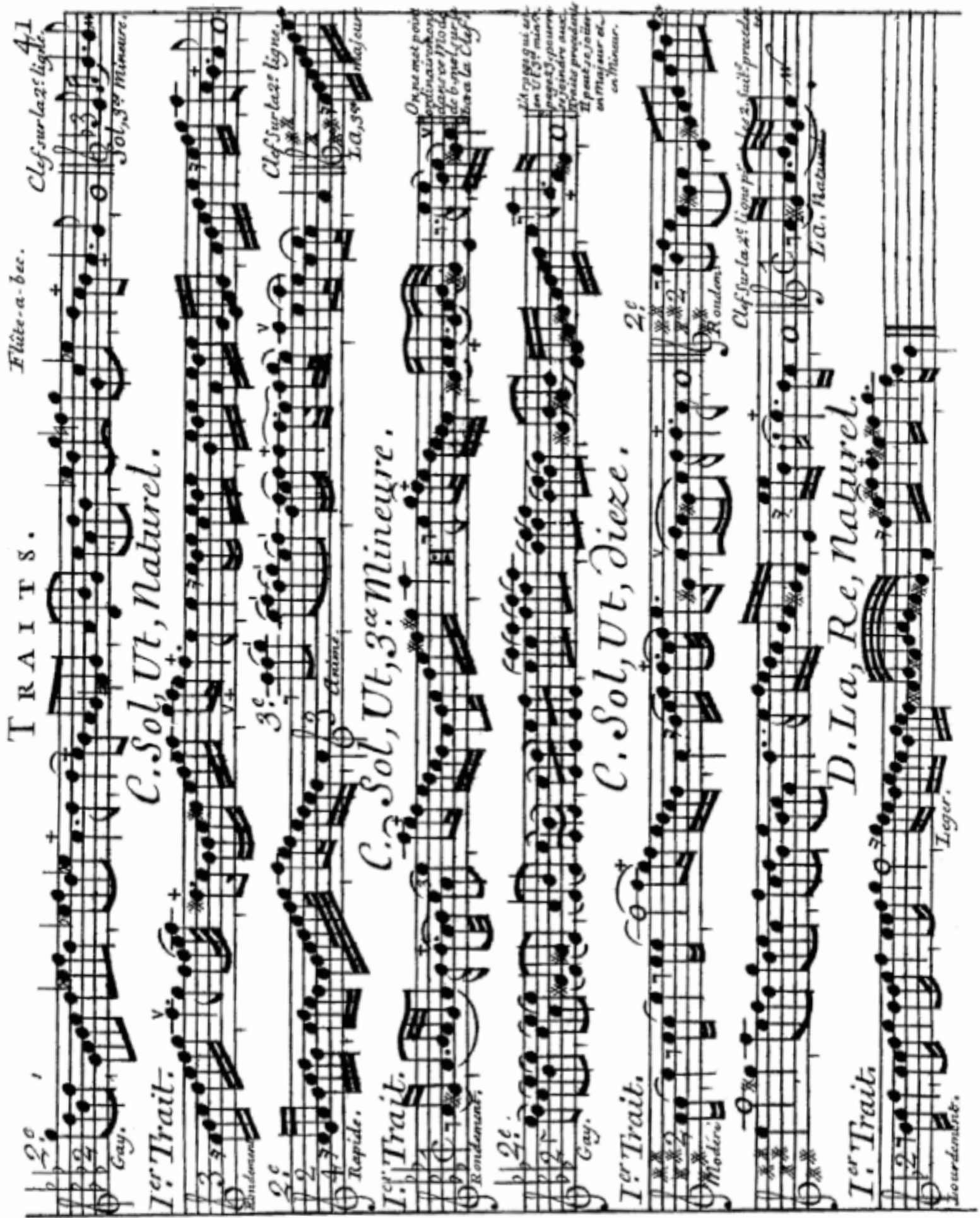




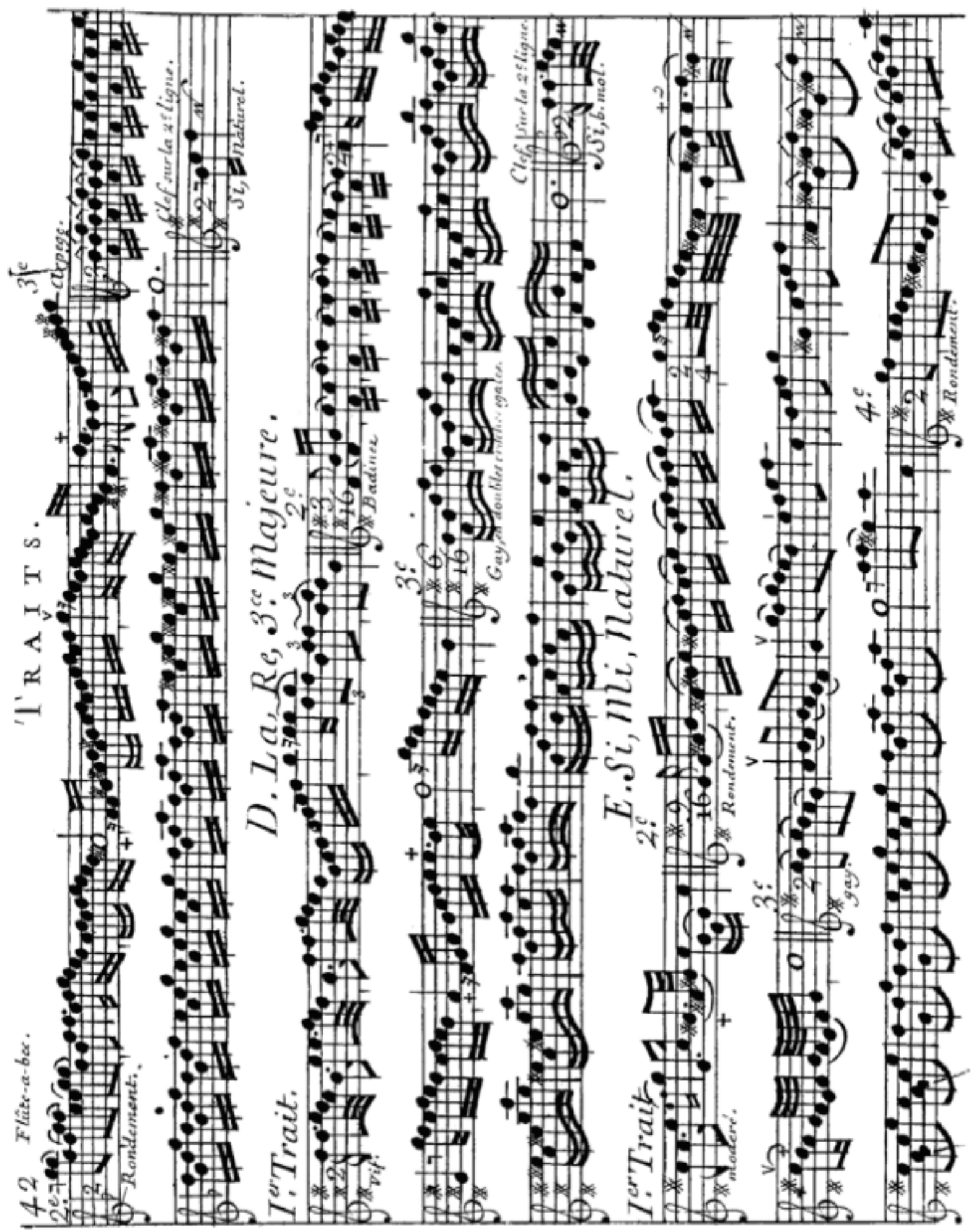




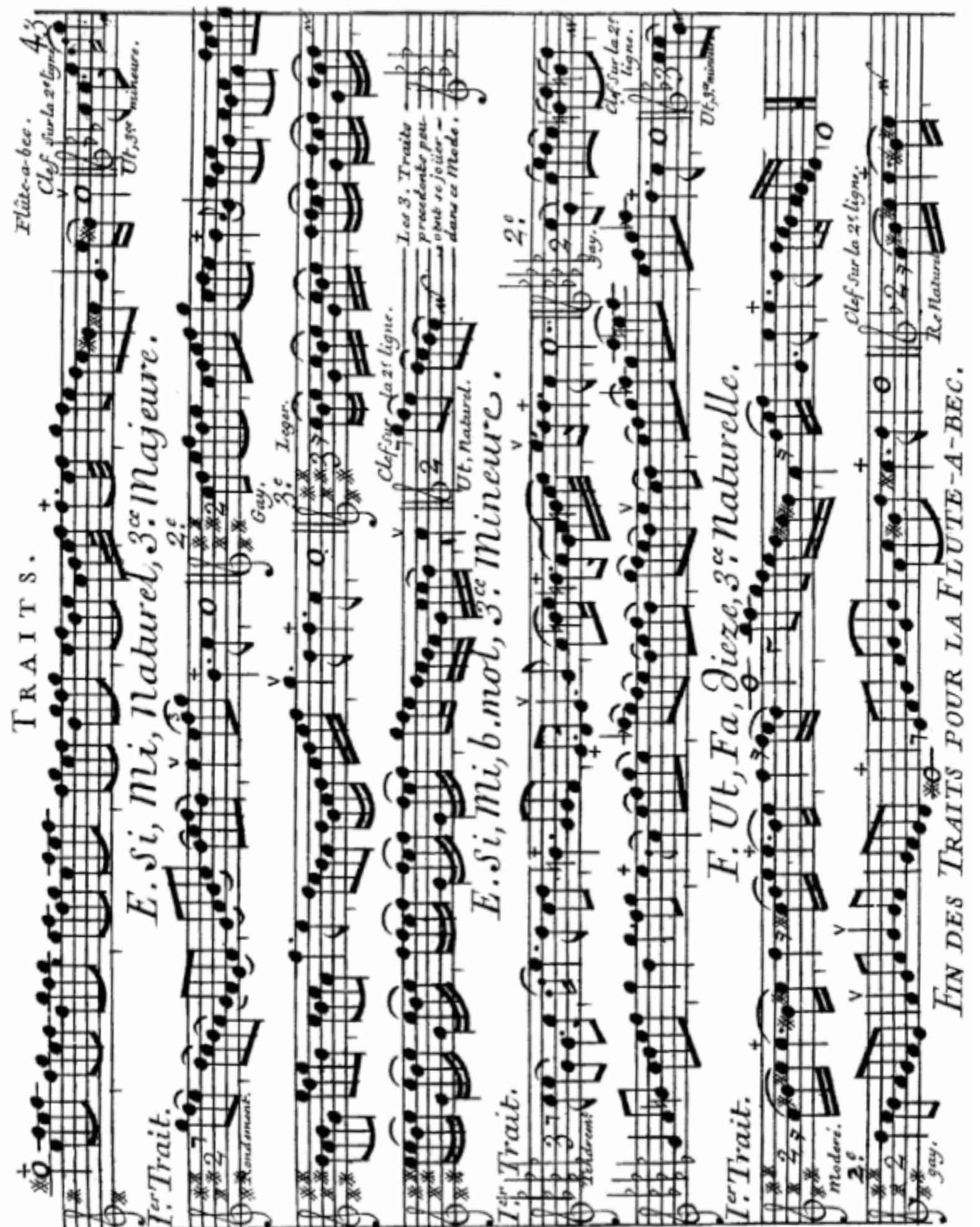

Fim dos traits para flauta doce. 


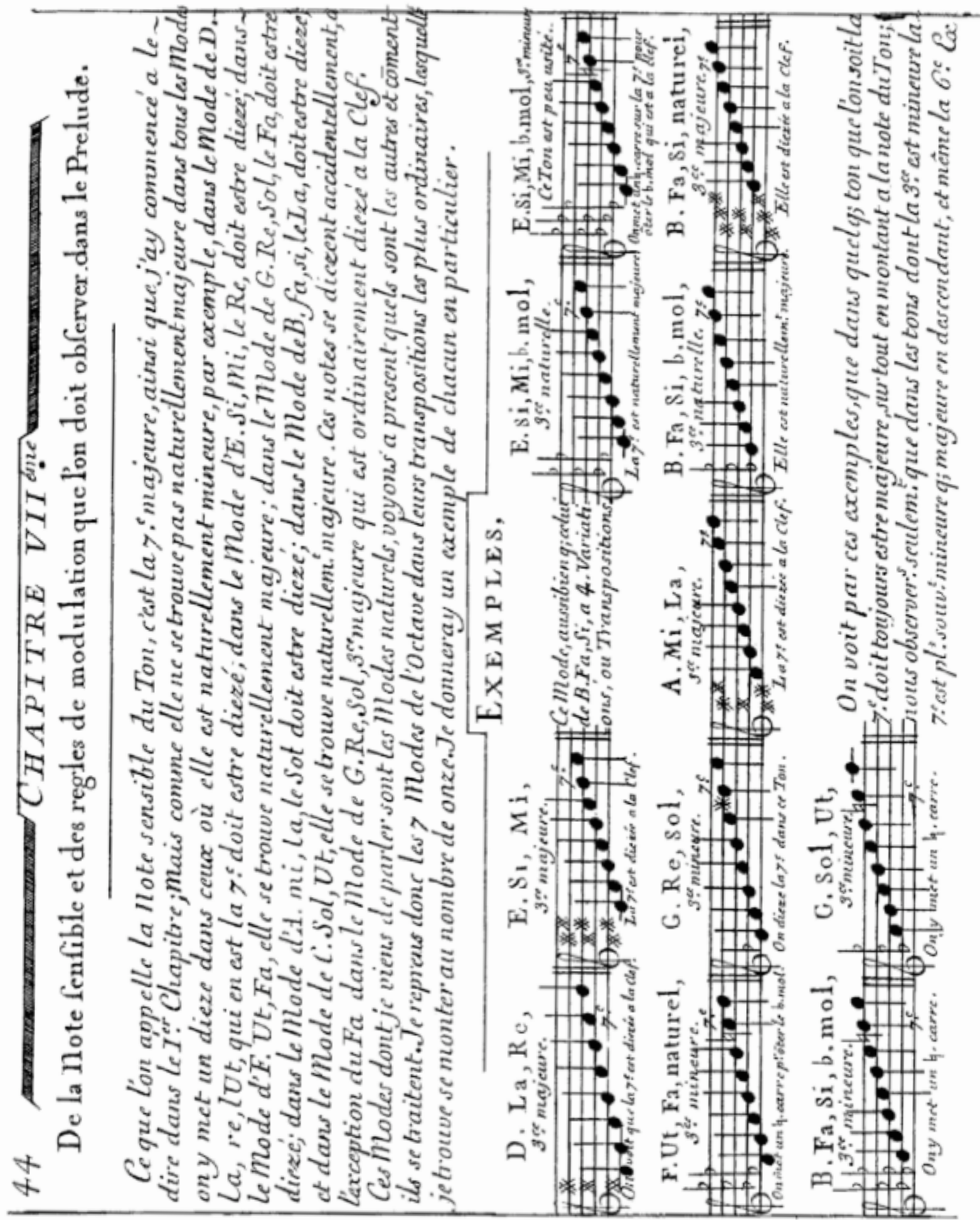




\section{Sétimo Capítulo}

\section{Da nota sensível e das regras de modulação que se deve observar no prelúdio.}

Chamamos a sétima maior de nota sensível do tom, assim como comecei a dizê-lo no primeiro capítulo; mas como esta não se encontra naturalmente maior em todos os modos, põe-se o sustenido naquelas onde ela é naturalmente menor. Por exemplo, no modo de D lá ré, o ut, que neste modo é a sétima, deve ser sustenido; no modo de $\mathrm{E}$ si $\mathrm{mi}$, o ré deverá ser sustenido; no modo de $\mathrm{F}$ ut fá, ela se encontra naturalmente maior; no modo de $\mathrm{G}$ ré sol, o fá deve ser sustenido; no modo de $\mathrm{A}$ mi lá, o sol deverá ser sustenido; no modo de B fá si, o lá deverá ser sustenido; e no modo de C sol ut, ela se encontra naturalmente maior.

Essas notas são acidentalmente sustenidas, com exceção do fá no modo de G ré sol terça maior, que é geralmente sustenido na armadura de clave. Esses modos, dos quais acabo de falar, são os modos naturais. Vejamos agora quais são os outros e como se tratam.

Refiro-me, portanto, aos sete modos da oitava nas suas transposições mais comuns, as quais encontro no número de onze. Darei um exemplo de cada um em particular.

Exemplo

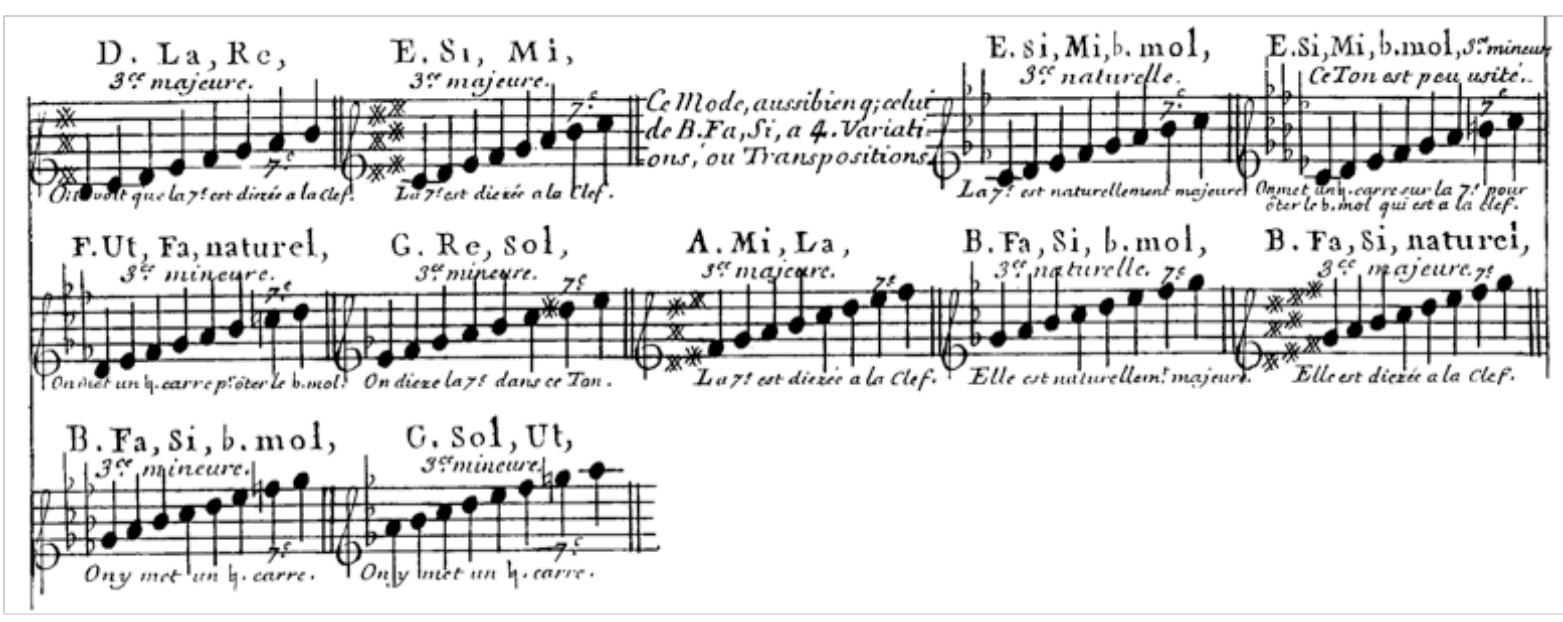

D, lá,ré terça maior: a sétima é sustenida na armadura de clave.

$\mathrm{E}, \mathrm{si}, \mathrm{mi}$ terça maior: a sétima é sustenida na armadura de clave.

Esse Modo, assim como o de B, fá, si, tem 4 variações ou transposições.

$\mathrm{E}$, si, mi bemol terça natural: a sétima é naturalmente maior.

$\mathrm{E}$, si, mi bemol terça menor: Esse tom é pouco utilizado. Coloca-se um bequadro

sobre a sétima para tirar o bemol que está na armadura de clave.

F, ut, fá terça menor: Coloca-se um bequadro sobre a sétima para tirar o bemol.

$G$, ré, sol terça menor: Coloca-se um sustenido na sétima desse tom.

$\mathrm{A}, \mathrm{mi}$, lá terça maior: A sétima é sustenida na armadura de clave.

$B$, fá, si bemol terça natural: Ela é naturalmente maior.

$B$, fá, si natural terça maior: Ela é sustenida na armadura de clave.

$B$, fá si bemol terça menor: Coloca-se um bequadro na sétima.

C, sol ut terça menor: Coloca-se um bequadro na sétima. 


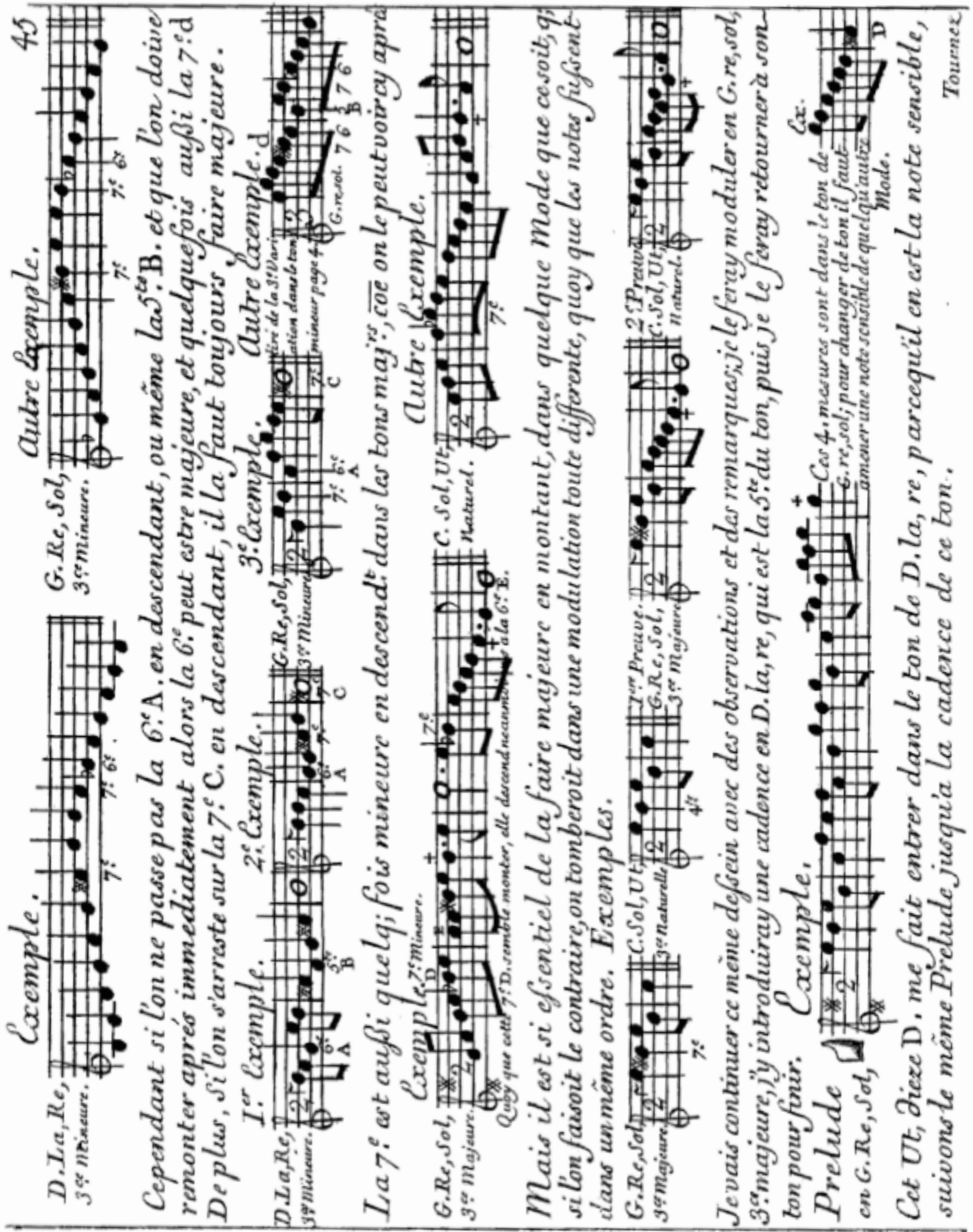


Vê-se por estes exemplos que, em qualquer tom que seja, a sétima nota deve sempre ser maior, sobretudo ascendendo à nota do tom; observaremos apenas que nos tons dos quais a terça é menor, a sétima é frequentemente menor que maior descendendo, e o mesmo com a sexta.
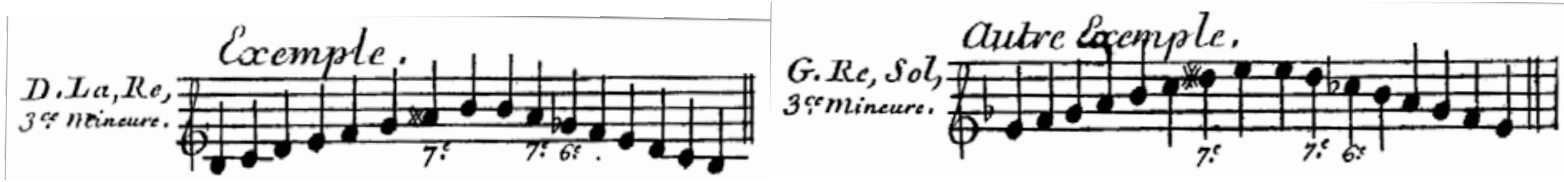

Contudo, se não se passa pela sexta $A$ descendo ou mesmo pela quinta $B$, sem subir depois imediatamente, então a sexta pode ser maior, e às vezes também a sétima D. Além disso, se se pára sobre a sétima $C$ descendo, é necessário sempre fazê-la maior.

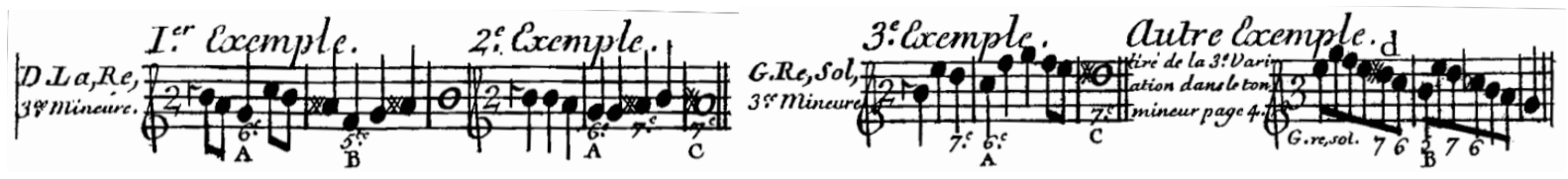

Tirado da terceira variação no tom menor da página 99.

A sétima é também às vezes menor quando se está descendo nos tons maiores, como se pode ver aqui.

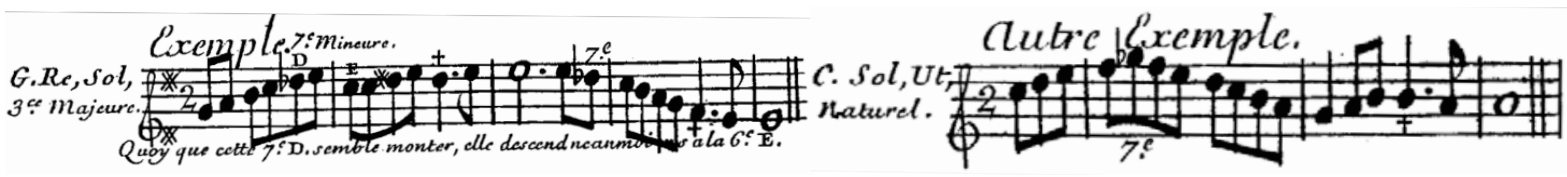

Mas é tão essencial fazê-la maior quando ascendente em qualquer modo que seja que, se fizesse o contrário, ela cairia numa modulação muito diferente, embora as notas estejam numa mesma ordem.

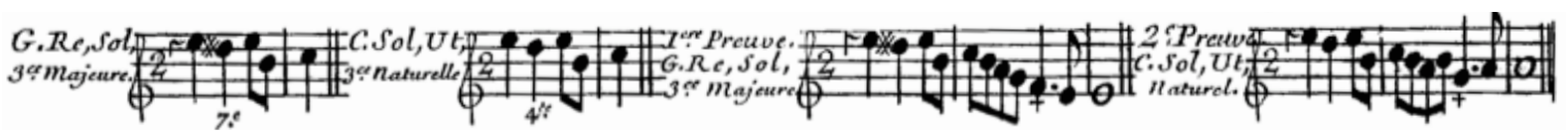

Vou continuar essa mesma estrutura [dessein] com observações e comentários; eu a farei modular em $G$ ré sol, terça maior, introduzirei uma cadência em $D$ lá ré, que é a quinta do tom, então a farei voltar ao seu tom para terminar. 


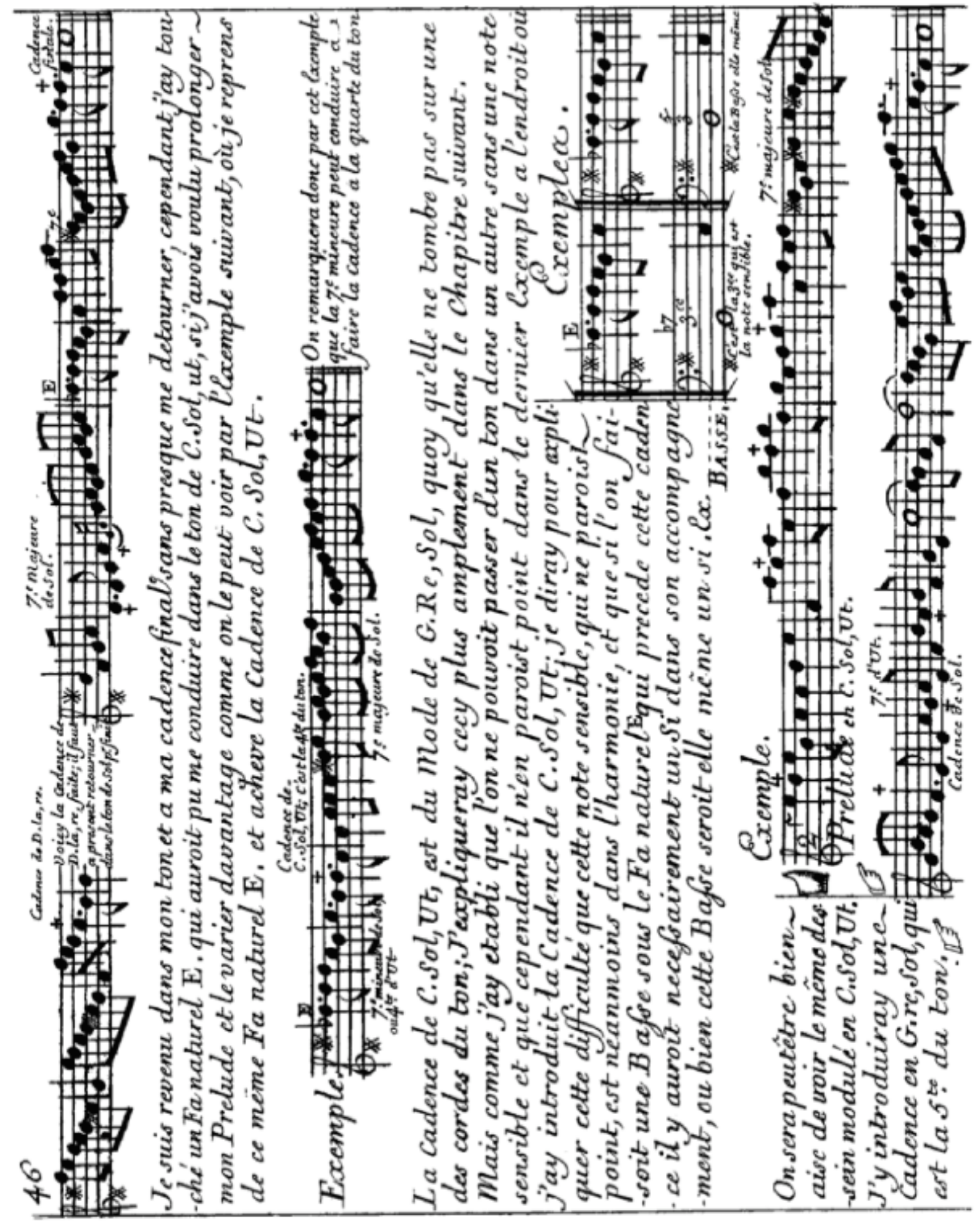




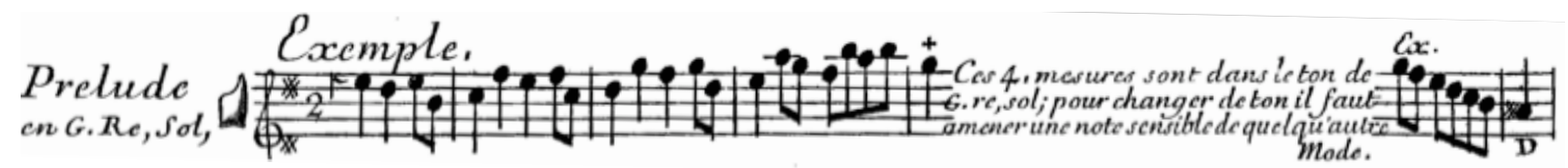

Estes quatro compassos estão no tom de G ré sol, para mudar o tom é necessário conduzir notas sensíveis de um outro modo.

Este ut sustenido D me faz entrar no tom de D lá ré, porque é a nota sensível; sigam o mesmo prelúdio até a cadência deste tom. Eis a cadência de D lá ré feita; é necessário, agora, voltar ao tom de sol para terminar.

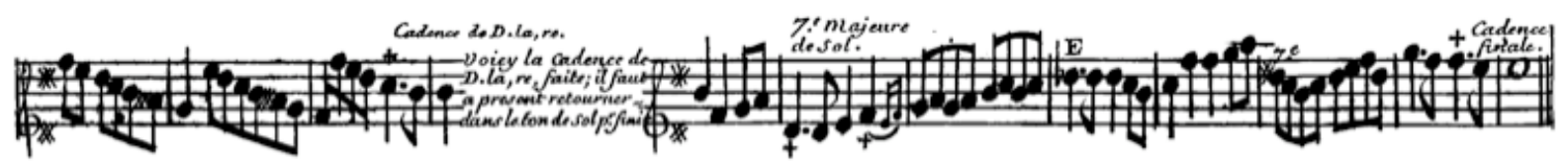

Retornei ao meu tom e à minha cadência final sem quase desviar-me do tom. Porém, toquei um fá natural $\mathrm{E}$ que poderia ter me conduzido ao tom de $\mathrm{C}$ sol ut se eu tivesse vontade de prolongar o meu prelúdio e variá-lo mais, como se pode ver pelo exemplo seguinte, onde retomo este mesmo fá natural $E$ e termino com a cadência de C sol ut.

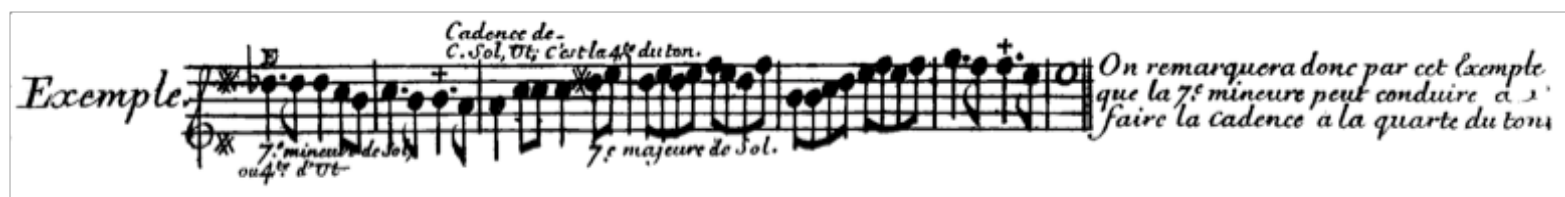

Observar-se-á portanto, por este exemplo, que a sétima menor pode levar a fazer a cadência na quarta do tom.

A cadência de $C$ sol ut está no modo de $G$ ré sol, embora ela não caia sobre uma das cordas do tom; explicarei isso mais amplamente no capítulo seguinte. Mas como estabeleci que não se podia passar de um tom ao outro sem uma nota sensível e que, contudo, essa nota não aparece no último exemplo no lugar onde introduzi a cadência de $\mathrm{C}$ sol ut, direi para explicar essa dificuldade que essa nota sensível, que não aparece, está no entanto na harmonia, e que se fizesse um baixo sob o fá natural $\mathrm{E}$ que precede essa cadência, haveria necessariamente um si no seu acompanhamento ou esse baixo seria propriamente um si. 

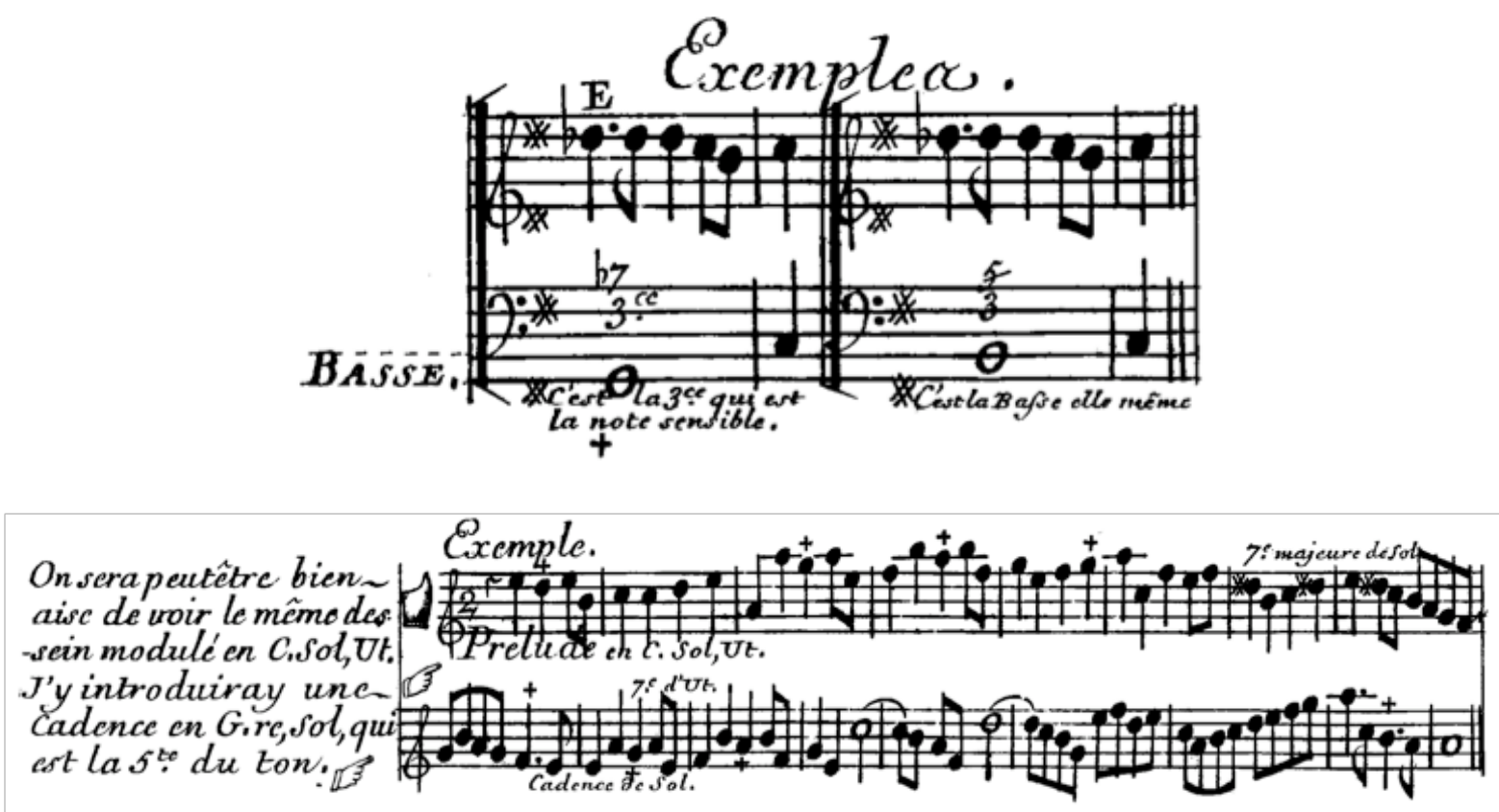

Será talvez muito bom ver a mesma estrutura modulada de C sol ut. Eu introduzirei ali uma cadência em $\mathrm{G}$ ré sol, que é a quinta do tom. 


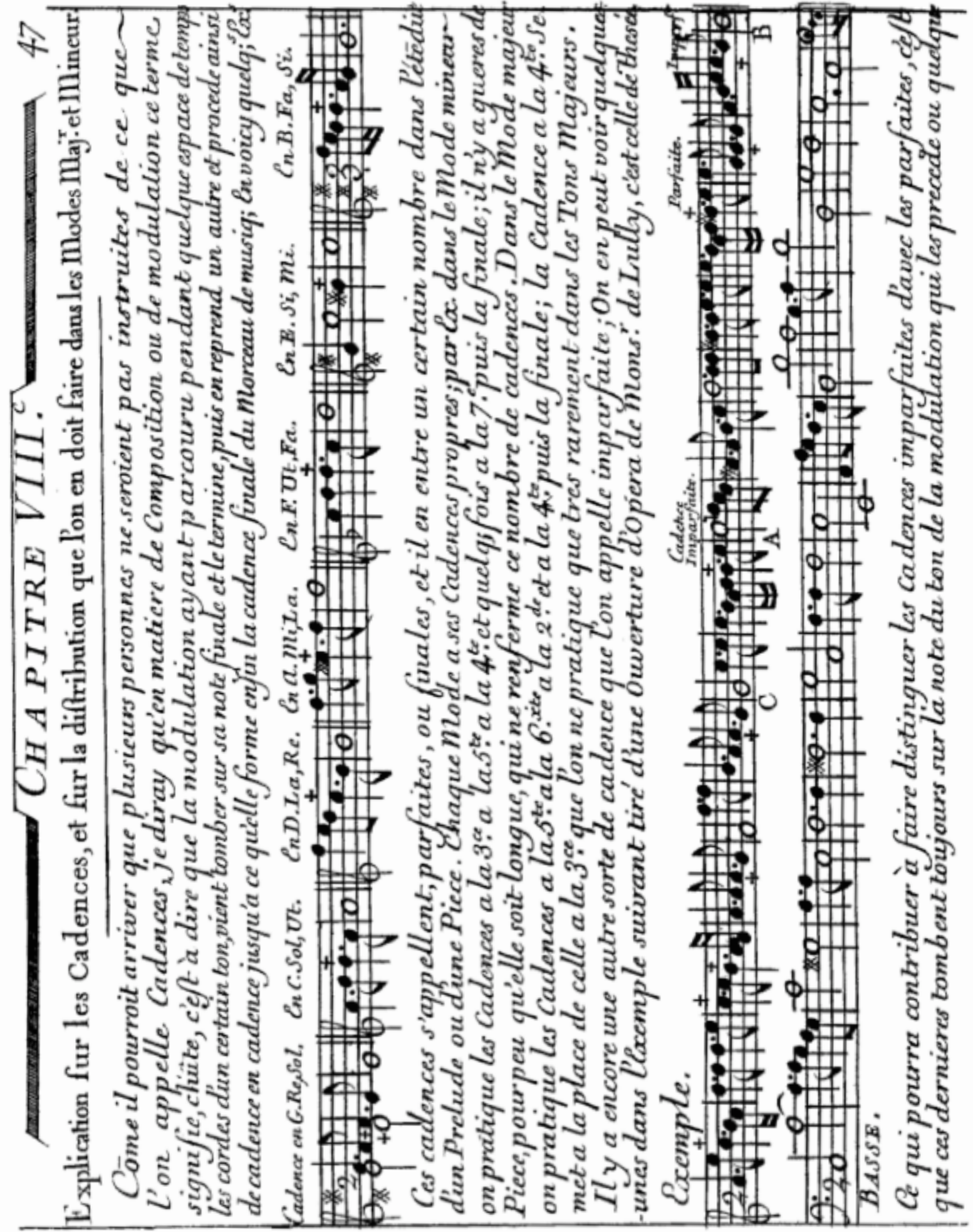




\section{Oitavo Capítulo}

\section{Explicação sobre as cadências, e sobre a distribuição que se deve fazer nos modos maior e menor.}

Como pode acontecer que várias pessoas não saibam o que é cadência, direi que em matéria de composição ou modulação este termo significa queda, ou seja, que a modulação que tem percorrido durante algum espaço de tempo as cordas de um certo tom vem cair sobre a sua nota final e termina; em seguida, retoma um outro tom e procede assim de cadência em cadência até que ela forme enfim a cadência final do trecho da música; eis aqui alguns exemplos:

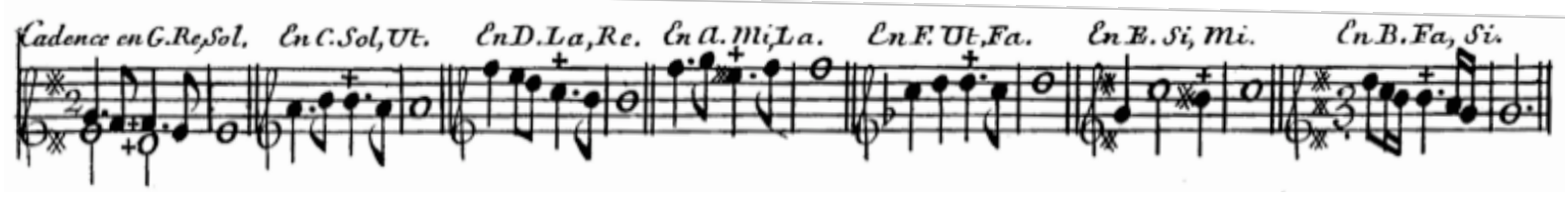

Essas cadências chamam-se perfeitas, ou finais, e apresentam-se em um certo número na duração de um prelúdio ou de uma peça. Cada modo tem as suas próprias cadências. Por exemplo, no modo menor se praticam as cadências na terça, na quinta, na quarta e, às vezes, na sétima seguidamente à final; não há peça, mesmo que curta, que não contenha esse número de cadências. No modo maior praticam-se as cadências de quinta, de sexta, de segunda, e de quarta, enfim a final; as cadências de quarta põem-se no lugar da terça, que se pratica muito raramente, apenas nos tons maiores. Há ainda outra espécie de cadência que se chama imperfeita; podem-se ver algumas no exemplo seguinte, tirado da Abertura da Ópera Thésée, do Sr. Lully.

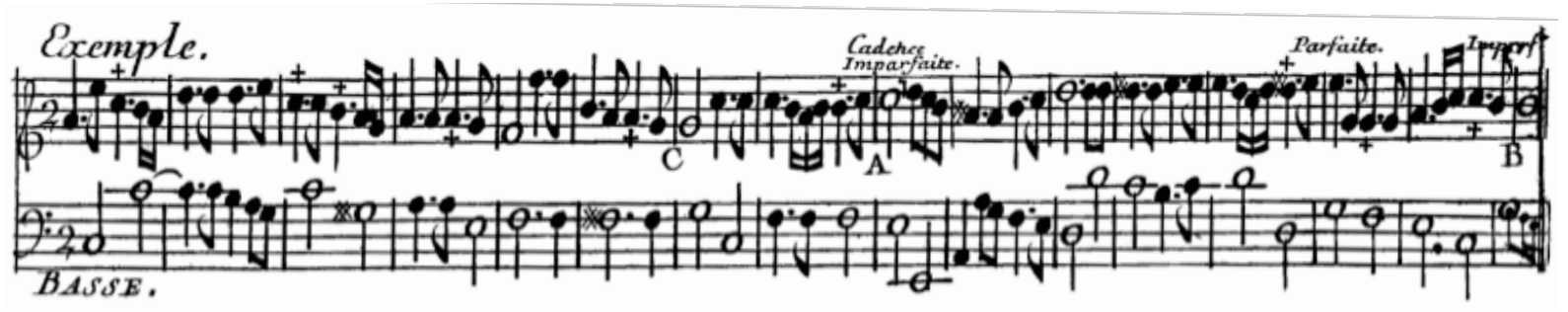

O que poderia contribuir para fazer distinguir as cadências imperfeitas das perfeitas é que estas últimas caem sempre sobre a nota do tom da modulação que as precede, ou às vezes na terça, mas raramente, ao contrário das imperfeitas, que se tratam de uma outra maneira, como se pode observar acima; por exemplo, a cadência A termina sobre o mi, mas ela não é precedida pela modulação desse tom, dado que o ré, que é a sétima, não é sustenido; é, portanto, imperfeita. 


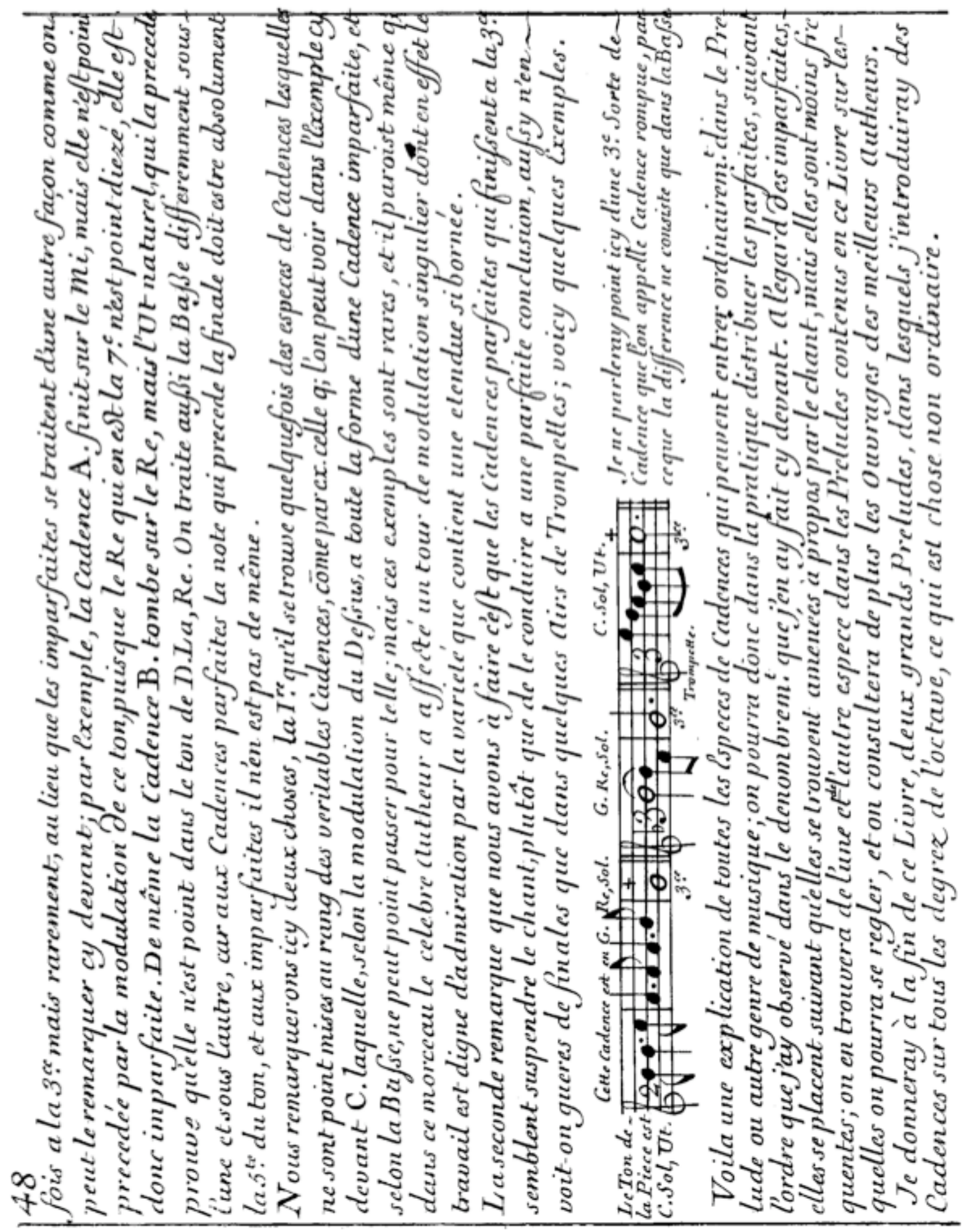


O mesmo se dá com a cadência $B$, que cai sobre ré, mas o ut natural, que a precede, prova que ela não está no tom de D lá ré. Trata-se também o baixo diferentemente sob um e sob o outro, porque nas cadências perfeitas a nota que precede a final deve ser absolutamente a quinta do tom, e nas imperfeitas não é da mesma maneira.

Observaremos aqui duas coisas: a primeira, que se encontram às vezes espécies de cadências as quais não são da mesma natureza das verdadeiras cadências, como por exemplo, a que se pode ver no exemplo acima $\mathrm{C}$, a qual, de acordo com a modulação da melodia ${ }^{215}$, tem toda a forma de uma cadência imperfeita, e de acordo com o baixo, não pode passar por tal; mas esses exemplos são raros, e parece mesmo que nesse pedaço o famoso Autor ${ }^{216}$ afetou o percurso de modulação singular da qual, de fato, o trabalho é digno de admiração pela variedade que contém uma extensão tão limitada. A segunda observação que temos a fazer é que as cadências perfeitas que terminam na terça parecem suspender o canto ${ }^{217}$ antes de conduzi-lo a uma perfeita conclusão, também não se vê muito em algumas Árias de Trompetes; eis alguns exemplos.

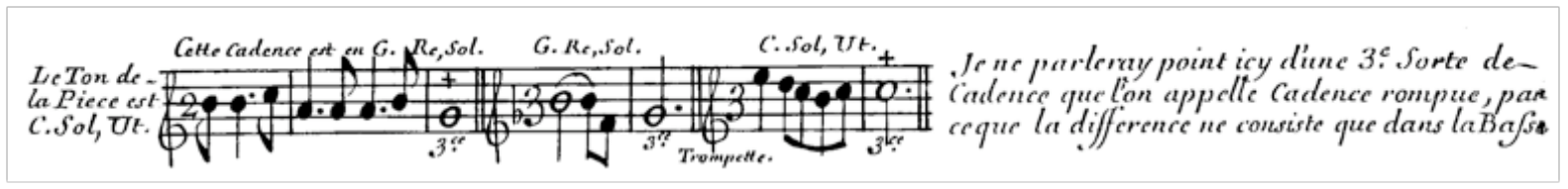

Não falarei aqui de uma terceira espécie de cadência, que se chama cadência quebrada, porque a diferença consiste apenas no baixo.

Eis uma explicação de todas as espécies de cadências que podem entrar geralmente no prelúdio ou em outro gênero de música; poder-se-á, portanto, na prática, distribuir as cadências perfeitas de acordo com a ordem que observei no enunciado que fiz acima. Em relação às cadências imperfeitas, colocam-se conforme se encontram conduzidas pelo canto, mas são menos frequentes; encontrar-se-á de uma ou de outra espécie nos prelúdios contidos neste livro acima, aos quais poder-se-á guiar e consultar mais das obras dos melhores autores. Darei no fim deste livro dois grandes prelúdios, nos quais introduzirei cadências sobre todos os graus da oitava, o que não é comum.

\footnotetext{
215 Dessus. Ver nota número 190.

216 O famoso autor a que se refere Hotteterre é Jean Baptiste Lully.

217 O termo chant, que foi traduzido como canto, para Furetière é sinônimo de melodia, ou a parte mais aguda da peça. "chant est aussi l'air, le recit, le dessus de la Musique". Cf. FURETIÈRE, A. Op. cit., vol. I.
} 


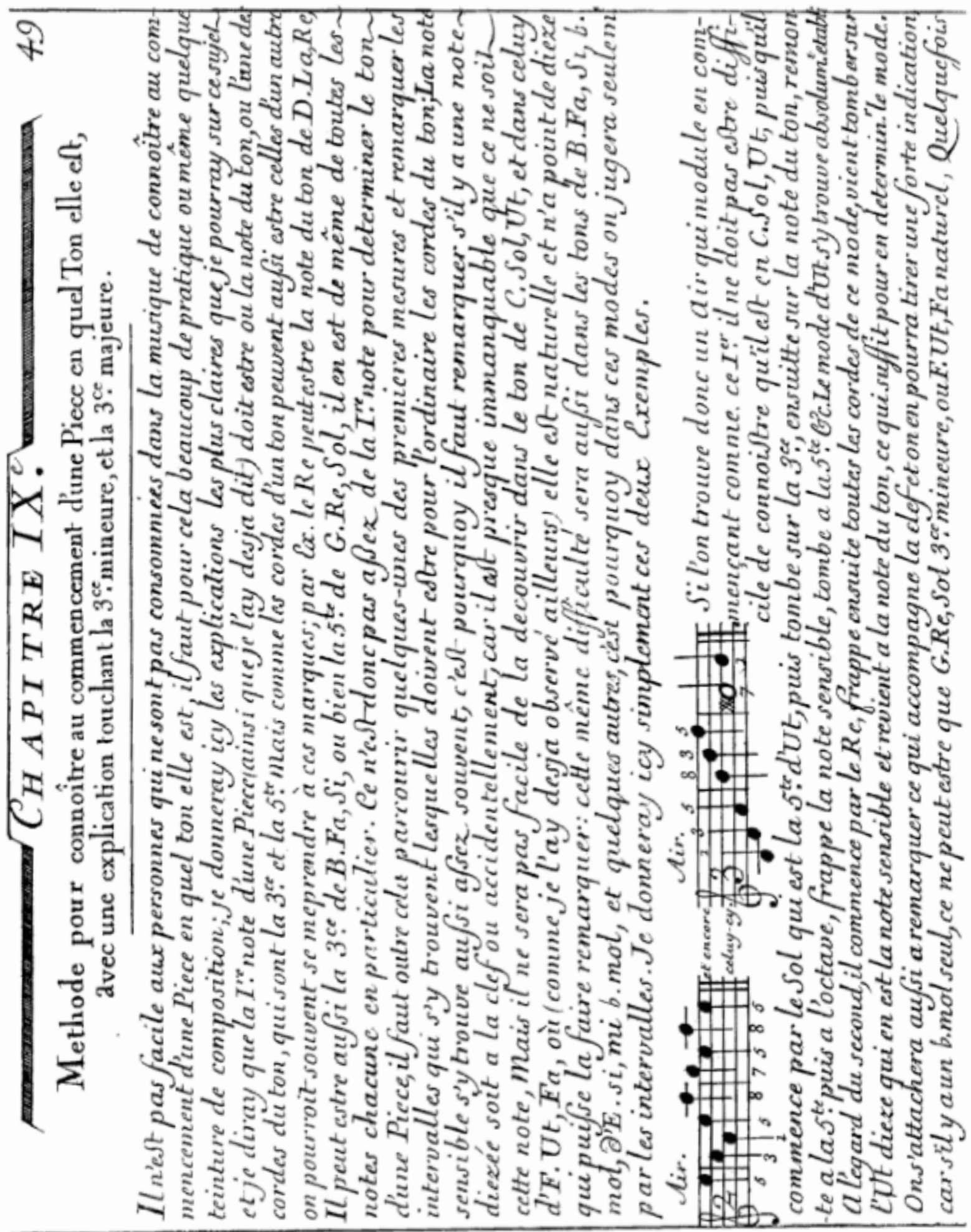




\section{Nono Capítulo}

\section{Método para conhecer ao início de uma peça em que tom ela está, com uma explicação a respeito da terça menor e da terça maior.}

Não é fácil para as pessoas que não são consumadas ${ }^{218}$ na música conhecer ao início de uma peça em qual tom ela está; é necessário para isso muita prática ou mesmo ter alguma noção de composição; darei aqui as explicações mais claras que poderei sobre esse assunto e direi que a primeira nota de uma peça (assim como já disse anteriormente) deve ser ou a nota do tom, ou uma das cordas do tom, que são a terça e a quinta. Mas como as cordas de um tom podem também ser as de outro, poder-se-ia frequentemente se enganar com essas marcas; por exemplo, o ré pode ser a nota do tom de $\mathrm{D}$ lá ré, pode ser também a terça de $\mathrm{B}$ fá si, ou a quinta de $\mathrm{G}$ ré sol; é a mesma de todas as notas, cada uma com a sua particularidade. Não é suficiente, portanto, a primeira nota para determinar o tom da peça, é necessário, além disso, percorrer alguns dos primeiros compassos e observar os intervalos que se encontram, quais devem ser comuns às cordas do tom; a nota sensível encontra-se frequentemente, é por isso que é necessário observar se há uma nota com sustenido quer na armadura de clave ou acidentalmente, porque é quase inevitável que seja essa nota, mas não será fácil descobri-la no tom de $\mathrm{C}$ sol ut, e o de $\mathrm{F}$ ut fá, onde (como já observei noutro lugar) ela é natural, não tendo o sustenido que possa fazê-lo observar; essa mesma dificuldade estará também nos tons de B fá si bemol, de E si mi bemol, e qualquer outro; é por isso que estes modos julgar-se-ão apenas pelos intervalos. Darei aqui simplesmente estes dois exemplos.

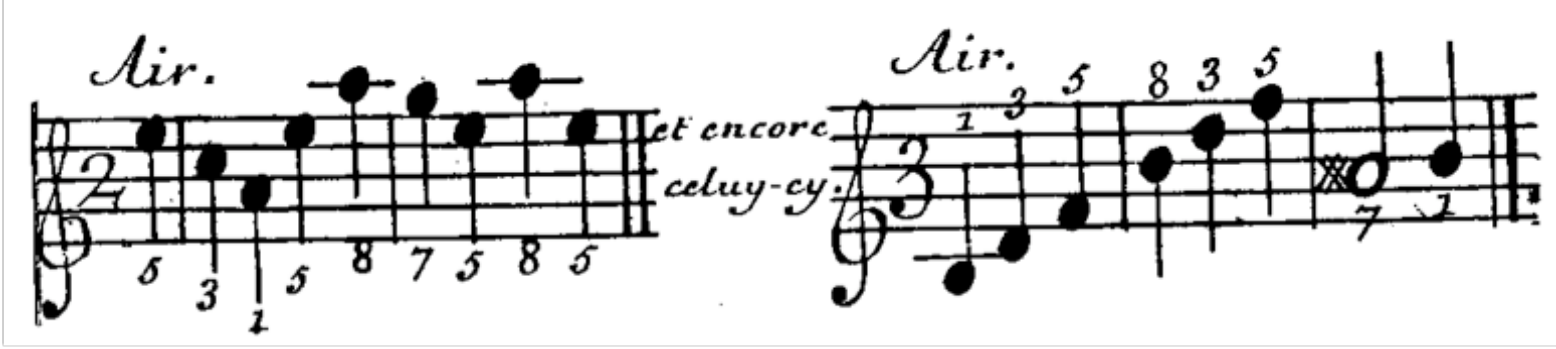

E ainda este

Se se encontra portanto uma ária que modula começando como esse primeiro exemplo, não deve ser difícil conhecer que ele está em $\mathrm{C}$ sol ut, dado que começa pelo sol, que é a quinta de ut, seguidamente cai sobre a terça, depois sobre a nota do tom, sobe à quinta e seguidamente à oitava, atinge a nota sensível, cai na quinta etc.. O modo de ut encontra-se absolutamente estável.

\footnotetext{
218 consumado: de alto nível, perito, competente, que atingiu o máximo em certa característica, perfeito. In: Dicionário Eletrônico HOUAISS da Língua Portuguesa. Rio de Janeiro: Ed. Objetiva, 2001.
} 


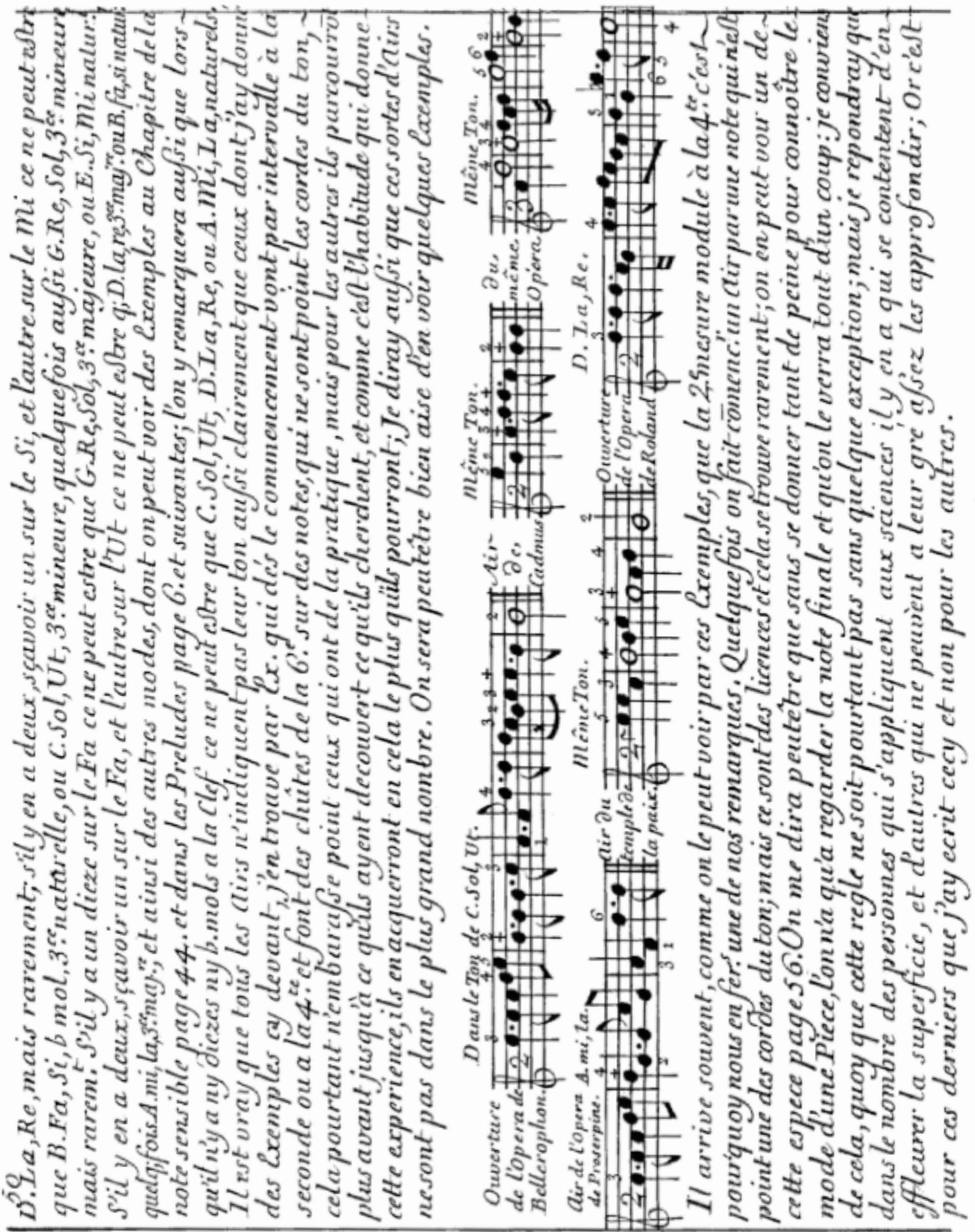


Em relação ao segundo, ele começa pelo ré, atinge seguidamente todas as cordas desse modo, vem cair sobre o ut sustenido, que é a nota sensível, e retorna à nota do tom, o que é suficiente para determinar o modo.

Dedicando-se a observar o que acompanha a clave, também se poderá tirar uma forte indicação, porque, se há um único bemol, pode ser $G$ ré sol terça menor, ou $F$ ut fá natural, às vezes $\mathrm{D}$ lá ré, mas raramente; se na armadura há dois bemóis, um sobre o si, e o outro sobre o mi, pode ser apenas B fá si bemol terça natural, ou C sol ut terça menor, às vezes também $\mathrm{G}$ ré sol terça menor mais raramente.

Se há um sustenido sobre o fá pode ser apenas $G$ ré sol terça maior, ou $E$ si mi natural. Se lá há dois, um sobre o fá, e o outro sobre ut, pode ser apenas D lá ré terça maior ou B fá si natural, às vezes $A$ mi lá terça maior, e assim dos outros modos, dos quais se podem ver exemplos no capítulo da nota sensível pag. 149 e nos prelúdios página 105 e seguintes; observar-se-ão também que quando não há nem sustenido nem bemol na clave pode ser apenas $\mathrm{C}$ sol ut, $\mathrm{D}$ lá ré ou $\mathrm{A}$ mi lá naturais.

É fato que todas as árias não indicam o seu tom tão claramente como os das quais dei exemplos acima; encontro, por exemplo, que a partir do início vão por intervalo à segunda ou à quarta e caem na sexta sobre notas que não são as cordas do tom; aquilo no entanto não embaraça os que têm a prática, mas para os outros, eles percorrerão mais antes de descobrirem o que procuram, e como é o hábito que dá essa experiência, eles adquirirão naquilo que poderão; direi também que essas espécies de árias não são em maior número.

Será talvez necessário ver alguns exemplos:

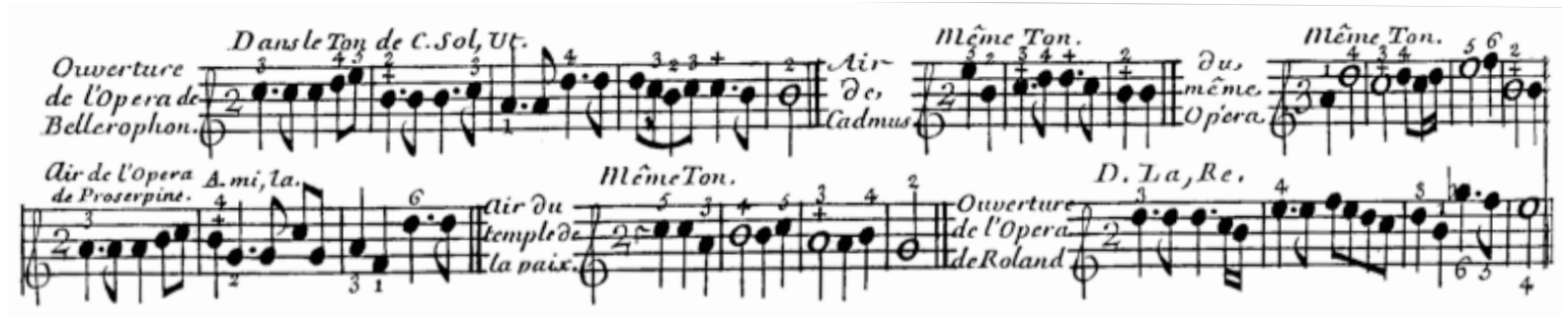

Abertura da ópera Bellerophon no tom de C sol ut; Ária de Cadmus, mesmo tom; da mesma ópera, mesmo tom; Ária da ópera de Proserpine, A mi lá; Ária do templo da paz, mesmo tom; Abertura da ópera Roland, D lá ré.

Acontece frequentemente, como se pode ver por estes exemplos, que o segundo compasso modulou para a quarta; é por isso que faremos uma das nossas observações. Às vezes faz-se começar uma ária por uma nota que não é uma das cordas do tom, mas são licenças ${ }^{219}$ e isso encontra-se raramente; pode-se ver uma dessa espécie na página 175. Dir-me-ão talvez que, sem estar a dar-se tanta dificuldade para conhecer o modo de uma peça, não se tem como se não olhar a nota final, e que se o verá muito de um momento: Concordo com isso, embora essa regra não exista sem uma exceção; mas responderei que na totalidade das pessoas que se aplicam às ciências, existem as que se contentam em tocar a superfície dos conteúdos, e outras que sentem que nunca poderão se aprofundar o bastante; ora, é para estes últimos que escrevi isso e não para os outros.

219 O termo licence (licença) significa liberdade que se dá à um escritor ou um artista, em sua obra, de desrespeitar certas regras habituais. Cf. FURETIÈRE, A. Op. cit., vol. II. 


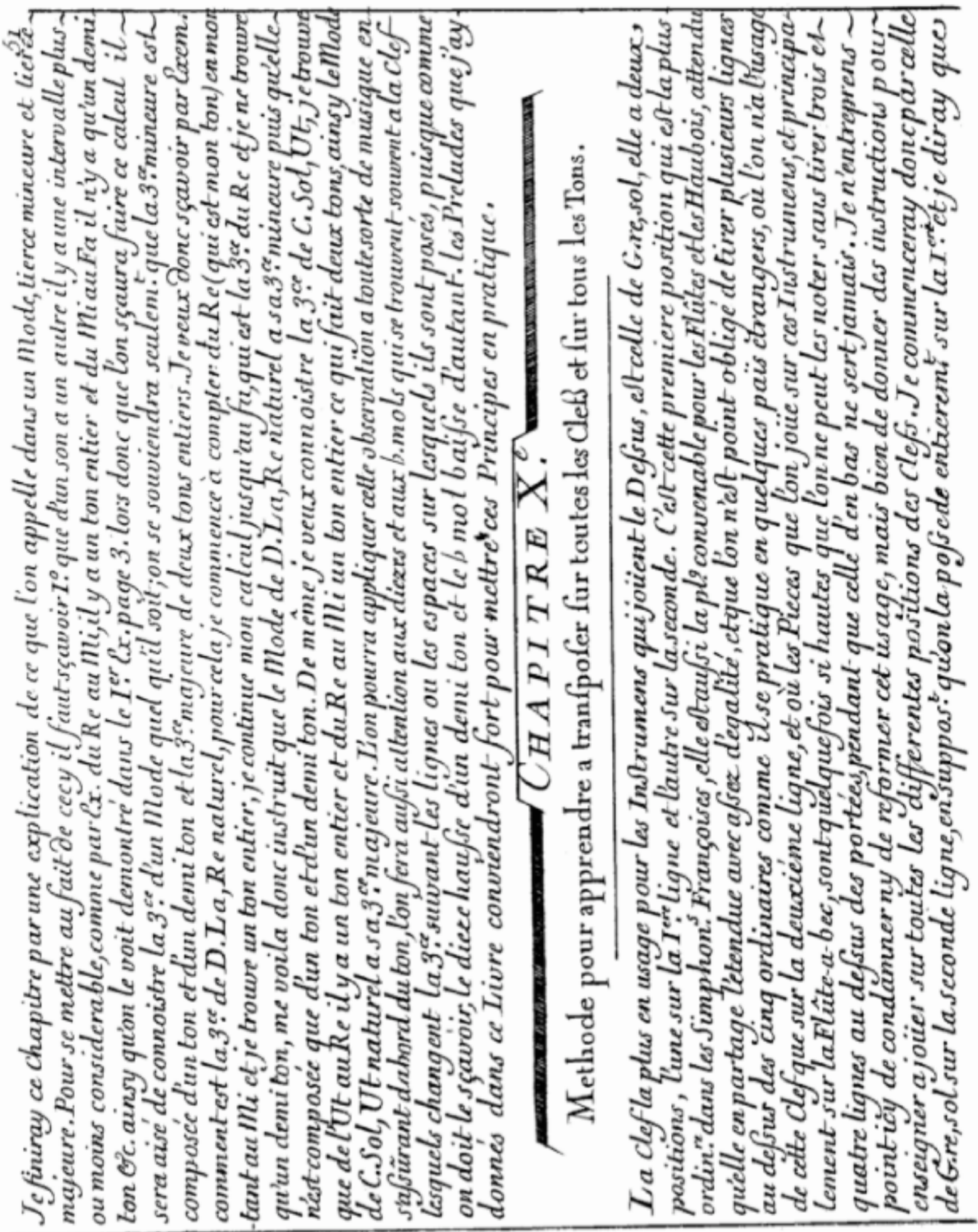


Terminarei este capítulo por uma explicação daquilo que se chama, num modo, terça maior e terça maior.

Para pôr-se ao fato disto é necessário saber primeiramente que de um som a outro há um intervalo mais ou menos considerável, como, por exemplo, do ré ao mi há um tom inteiro, e do mi ao fá há apenas um semitom etc., assim como se vê demonstrado no primeiro exemplo da página 95; na hora portanto que se saberá fazer esse cálculo será fácil conhecer a terça de um modo qualquer que seja; recordar-se-á apenas que a terça menor é composta de um tom e de um semitom, e a terça maior, de dois tons inteiros.

Quero portanto saber por exemplo como é a terça de D lá ré natural; para isso começo a contar do ré (que é o meu tom) e subindo ao mi encontro um tom inteiro; continuo o meu cálculo até ao fá, que é a terça do ré, e encontro apenas um semitom; isso, portanto, instrui-me que o modo de D lá ré natural tem sua terça menor, dado que é composta apenas de um tom e um semitom. Do mesmo modo quero conhecer a terça de $\mathrm{C}$ sol ut; encontro que do ut ao ré há um tom inteiro e do ré ao mi há um tom inteiro, o que faz dois tons; assim o modo de $\mathrm{C}$ sol ut natural tem sua terça maior.

Poder-se-á aplicar essa observação a qualquer espécie de música, assegurandose primeiro do tom, fazendo também atenção aos sustenidos e os bemóis que se encontram na armadura de clave, os quais alteram a terça de acordo com as linhas ou os espaços sobre os quais são postos, dado que, como se deve sabê-lo, o sustenido aumenta de semitom e o bemol reduz-se na mesma proporção. Os prelúdios que dei neste livro são extremamente adequados para pôr esses princípios em prática.

\section{Décimo Capítulo}

\section{Método para aprender a transpor sobre todas as claves e sobre todos os tons.}

A clave mais usada pelos instrumentos musicais que tocam a parte solista [dessus] é a de G ré sol; ela tem duas posições, uma sobre a primeira linha e a outra sobre a segunda. É esta primeira posição que é mais comum nas Sinfonias Francesas²20; ela é também a mais apropriada para as flautas e oboés, considerando que estes compartilham a extensão com bastante igualdade, e que não se é obrigado desenhar várias linhas acima das cinco comuns, como se pratica em alguns países estrangeiros, onde se tem o uso dessa clave apenas sobre a segunda linha, e onde as peças que se tocam sobre esses instrumentos, e principalmente sobre a flauta doce, são às vezes tão elevadas que não se pode notar sem desenhar três ou quatro linhas acima das usadas, enquanto as linhas inferiores não servem nunca. Não empreendo aqui condenar e nem reformar esse uso, mas dar instruções para ensinar a tocar sobre todas as diferentes posições de claves. Começarei portanto pela de G ré sol, sobre a segunda linha, supondo que se domine inteiramente a clave sobre a primeira, e direi que essa clave, assim transposta de dois graus, transpõe similarmente todas as notas que ela governa, de modo que o sol que se acostumou encontrar sobre a primeira linha estará agora sobre a segunda. 220 Música instrumental francesa. Mais informações sobre o stilo symphoniaco (denominação de
Brossard) são encontradas no primeiro capítulo deste trabalho. 


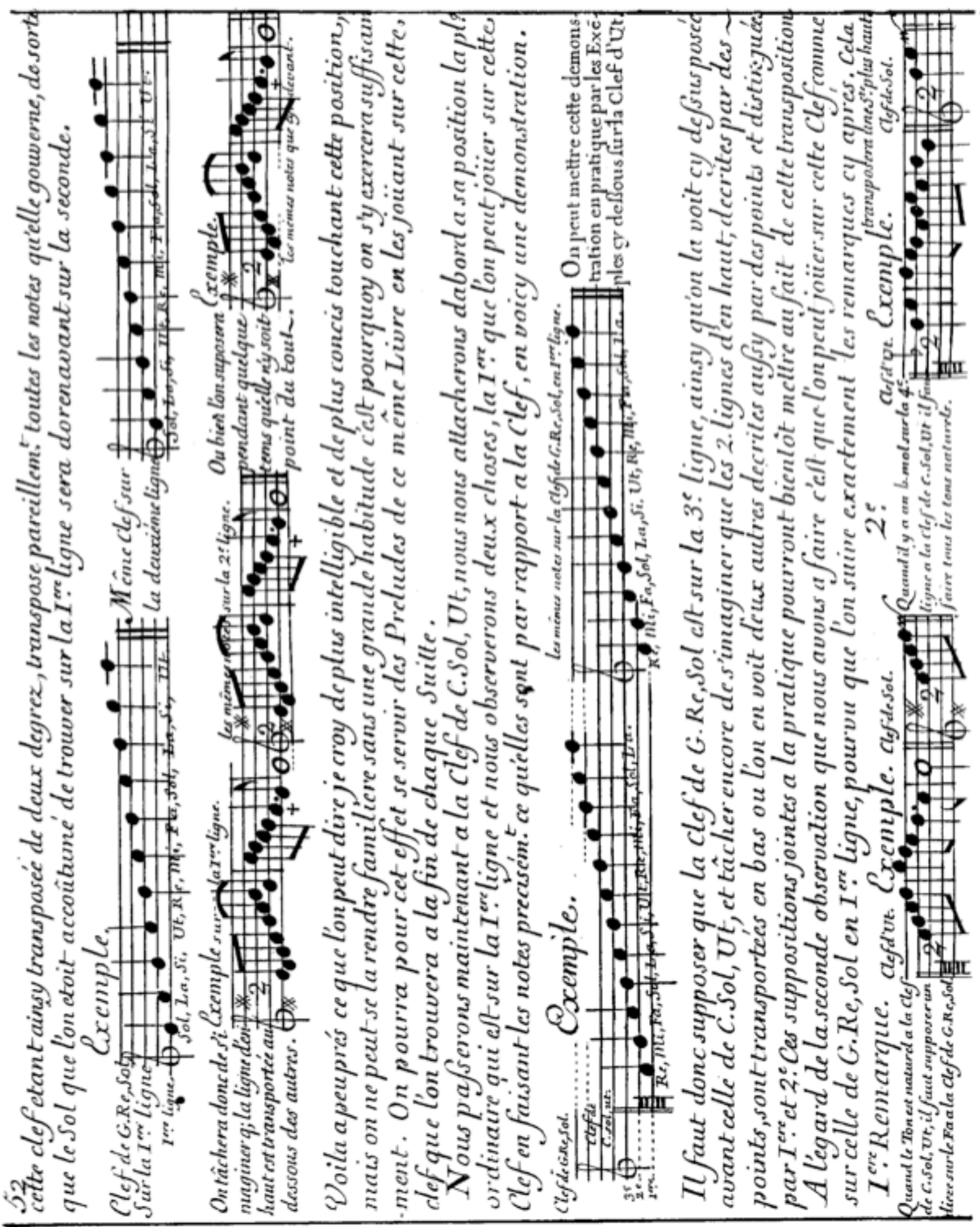



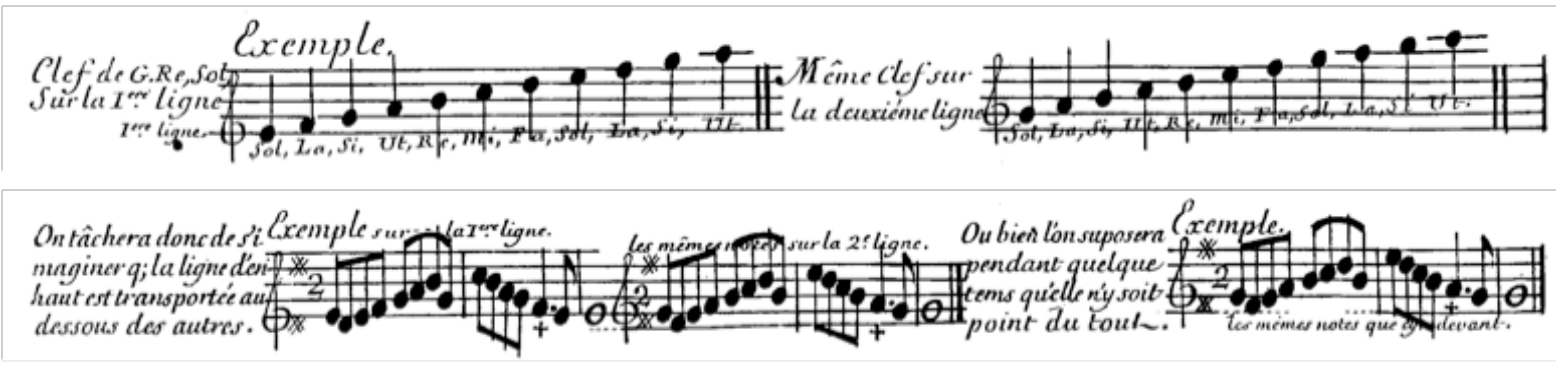

Tentar-se-á portanto imaginar que a linha superior é transposta abaixo das outras.

Ou se suporá depois de algum tempo que ela não esteja lá de nenhum modo.

Aí está mais ou menos o que se pode dizer, creio, de mais compreensível e mais conciso em relação a esta posição, mas não se pode torná-la familiar sem um grande hábito; é por isso que deve-se exercitar o suficiente. Para isso, poder-se-á se servir dos prelúdios deste mesmo livro, tocando sobre esta clave, que se encontrará no fim de cada série.

Passaremos agora à clave de $\mathrm{C}$ sol ut; primeiramente nos deteremos, à sua posição mais comum, que é sobre a primeira linha, e observaremos duas coisas: a primeira, que se pode tocar sobre esta clave fazendo as notas precisamente o que elas são em relação à clave; eis aqui uma demonstração.

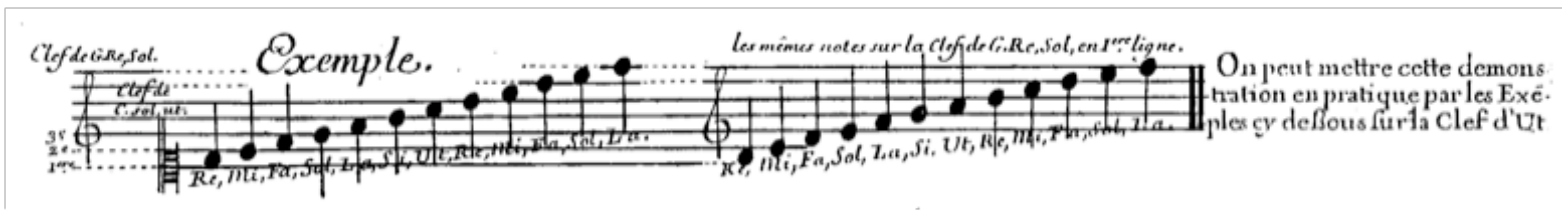

Pode-se colocar esta demonstração em prática pelos exemplos abaixo sobre a clave de ut.

É necessário portanto supor que a clave de G ré sol está sobre a terceira linha, assim como se a vê colocada acima antes da clave de $C$ sol ut, e tentar ainda imaginar que as duas linhas na parte superior, descritas por pontos, são transportadas inferiormente, onde se veem duas outras descritas também por pontos e distinguidas por primeira e segunda. Essas suposições, unidas à prática, poderão dentro de pouco tempo tornar fluente essa transposição.

Em relação à segunda observação que temos a fazer, é que se pode tocar sobre esta Clave como sobre a de G ré sol em primeira linha, desde que se sigam exatamente as observações seguintes. Isso transporá uma quinta acima.

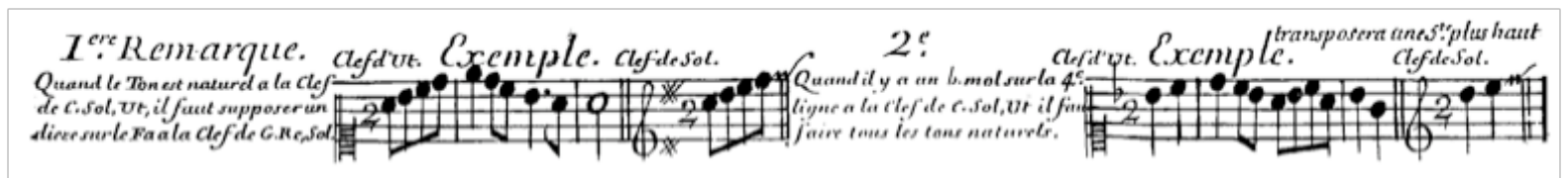

Quando o tom natural na clave do C sol ut, deve-se assumir um sustenido sobre o fá na clave do G ré sol.

Quando há um bemol na quarta linha na clave de C sol ut, devem-se fazer todos os tons naturais 


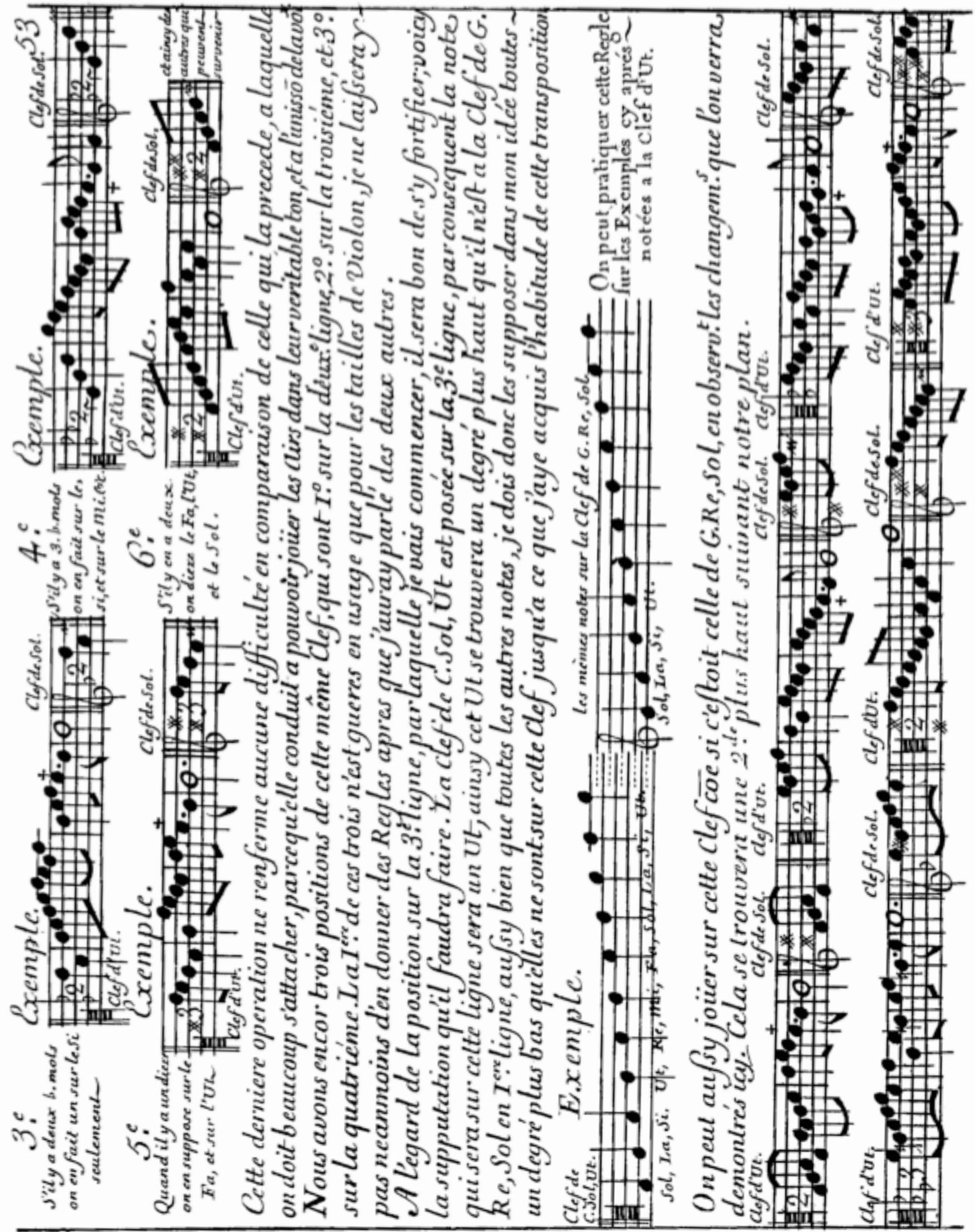




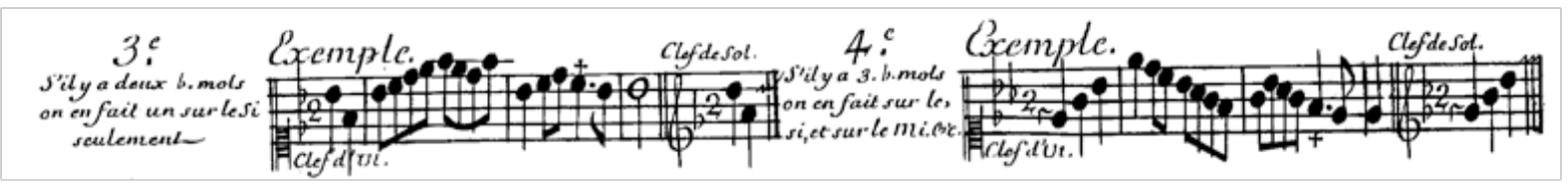

Se há dois bemóis, faz-se um sobre o si somente.

Se há três bemóis, fazem-se um sobre o si e outro sobre o mi.

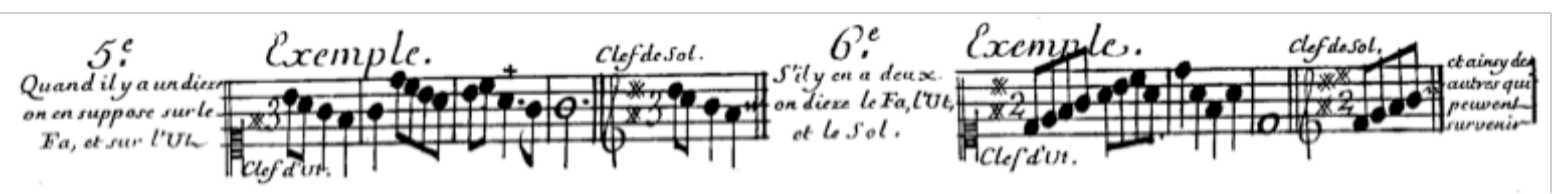

Quando há um sustenido, imagina-se um sobre o fá e outro sobre o ut.

Se há dois sustenidos, fazem-se um sobre o fá, um sobre o ut e outro sobre o sol.

Essa última operação não contém nenhuma dificuldade em comparação àquela que a precede, na qual se deve muito prestar atenção, porque poderá levar a tocar as árias no seu verdadeiro tom, e em uníssono com a voz.

Temos ainda três posições dessa mesma clave, que são em primeiro lugar sobre a segunda linha, em segundo sobre a terceira, e em terceiro sobre a quarta. A primeira dessas três é usada apenas para a tessitura do violino; não deixarei no entanto de dar regras depois que terei falado dos dois outros.

Em relação à posição sobre a terceira linha, pela qual vou começar, será bom reforçar; eis aqui o cômputo que será necessário fazer. A clave de $\mathrm{C}$ sol ut é posta sobre a terceira linha; portanto, a nota que estará sobre esta linha será o ut; assim este ut encontrar-se-á um grau acima do que ele está na clave de $\mathrm{G}$ ré sol em primeira linha, assim como todos as outras notas; devo portanto supor em minha mente todas um grau mais baixo que elas estão sobre essa clave até adquirir o hábito dessa transposição.

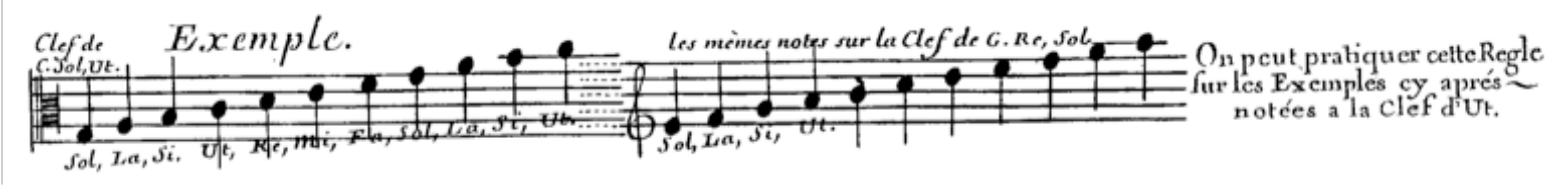

Pode-se praticar esta regra sobre os exemplos seguintes notados na clave de ut.

Pode-se também tocar sobre essa clave como se fosse a de G ré sol, observando as mudanças que serão demonstradas aqui. Isso se encontrará uma segunda acima segundo nosso plano.

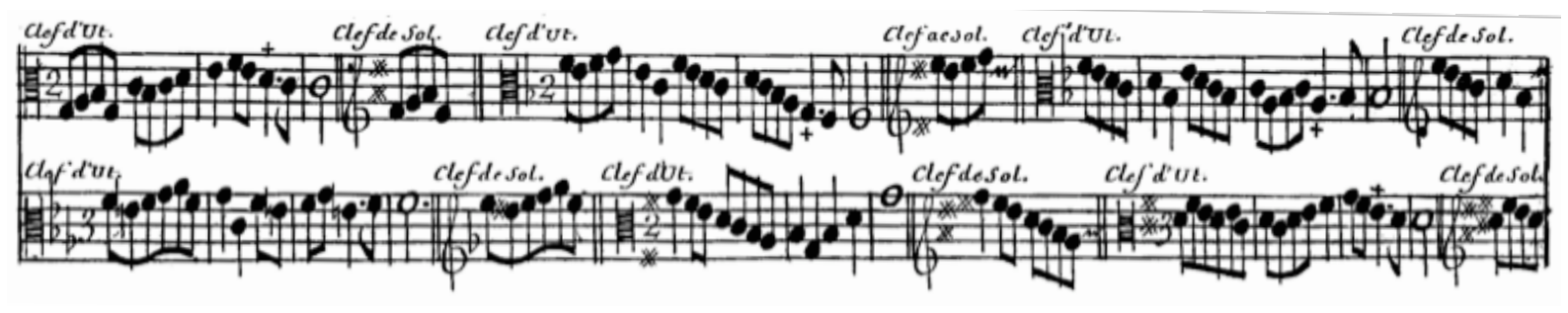




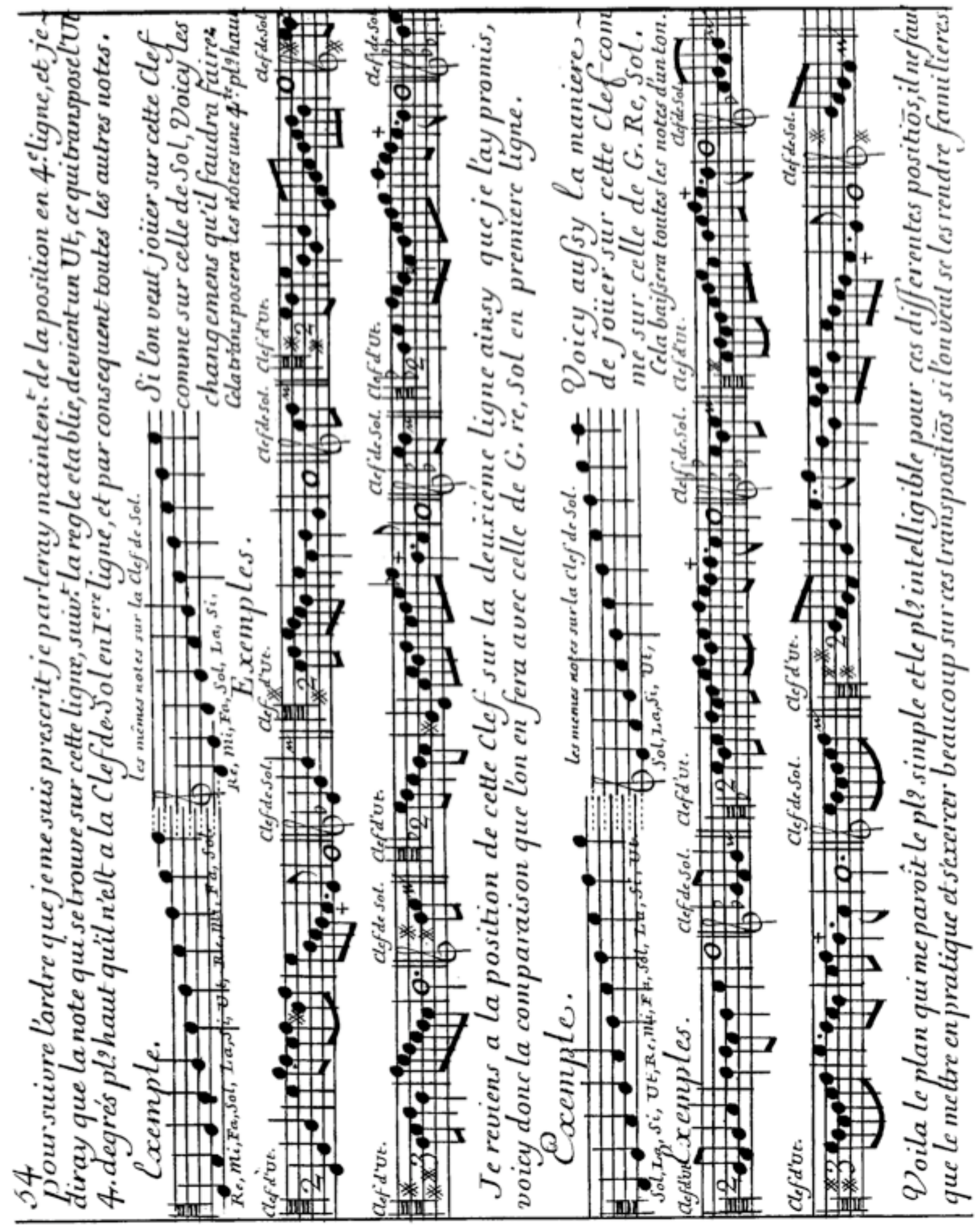


Para seguir a ordem que me prescrevi, falarei agora da posição na quarta linha, e direi que a nota que se encontra sobre essa linha, de acordo com a regra estabelecida, torna-se ut, o que transpõe o ut quatro graus acima do que está na clave de sol na primeira linha, e portanto todas as outras as notas.

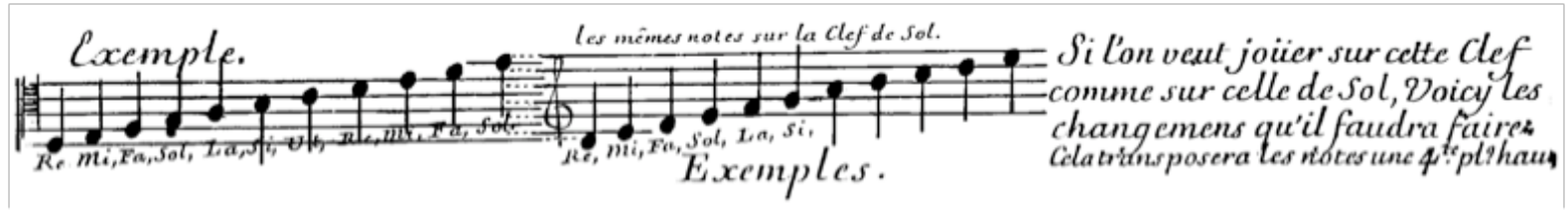

Se se quer tocar sobre essa clave como sobre a de sol, eis as mudanças que será necessário fazer. Isso transporá as notas numa quarta acima.

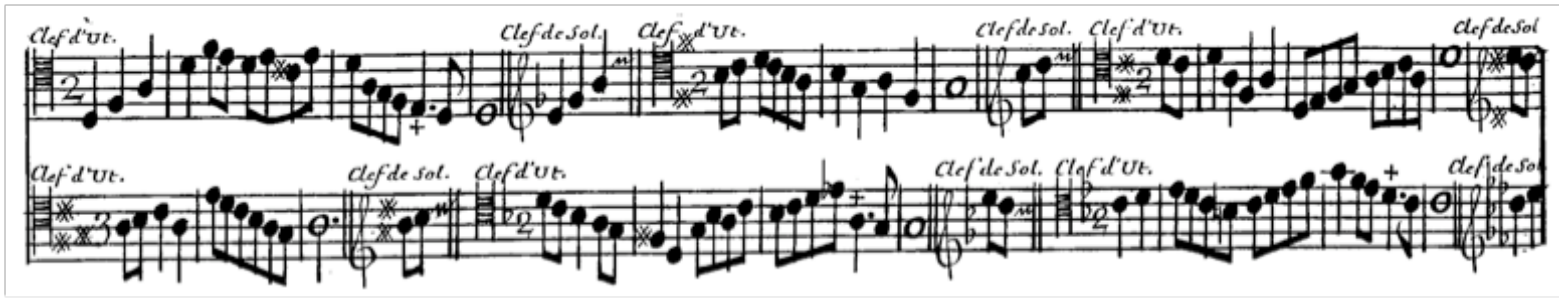

Retorno à posição dessa clave sobre a segunda linha assim como o prometi; eis portanto a comparação que se fará com a de G ré sol em primeira linha.

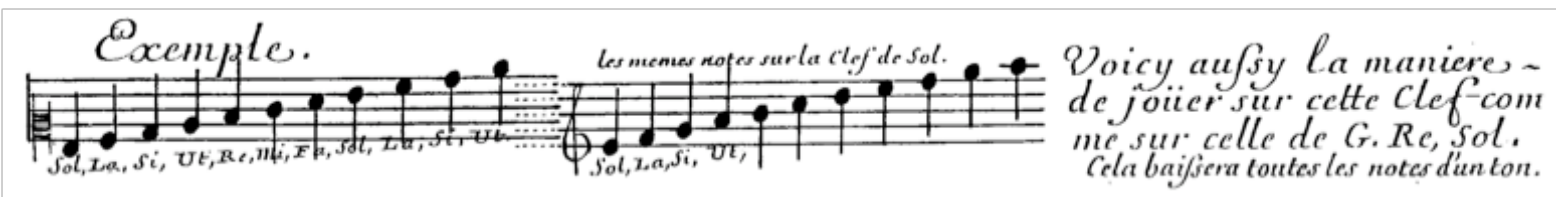

Aqui também a maneira de tocar sobre essa clave como sobre a de G ré sol. Isso reduzirá todas as notas em um tom.

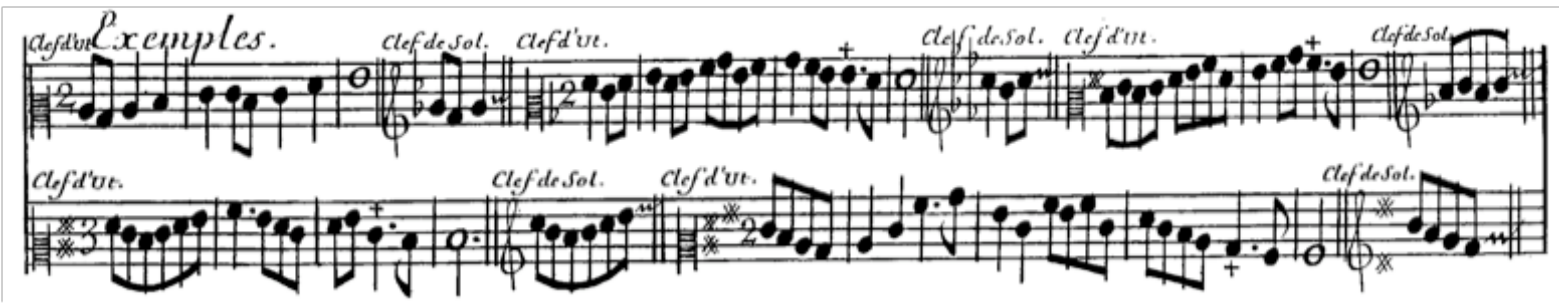

Aí está o plano que me parece mais simples e mais compreensível para essas diferentes posições; é necessário apenas colocá-lo em prática e exercitar-se muitas vezes sobre essas transposições, se se quiser torná-las familiares. 


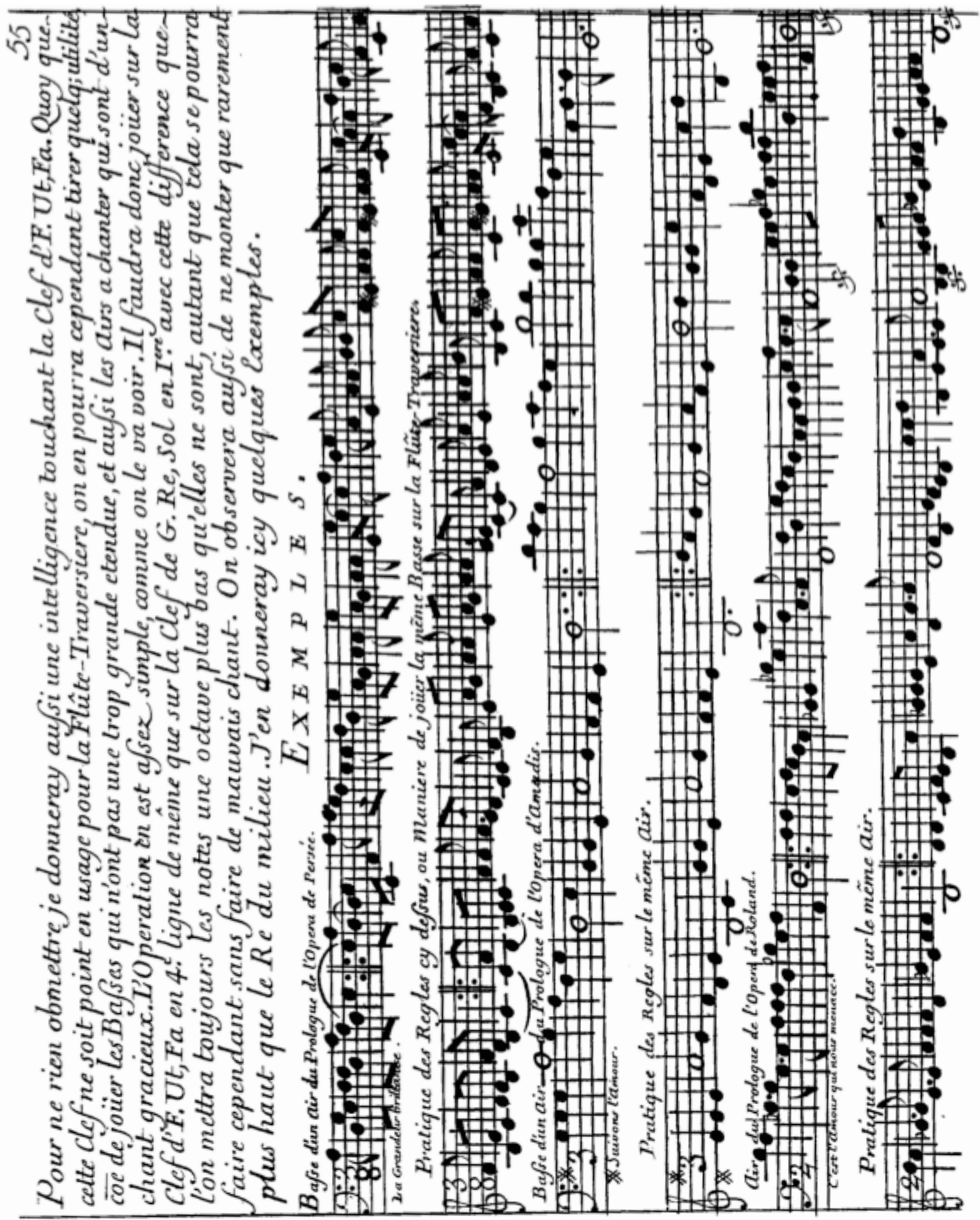


Para não omitir nada, darei também uma explicação a respeito da clave de $\mathrm{F}$ ut fá. Embora essa clave não esteja em uso para a flauta traversa, poder-se-á contudo tirar alguma utilidade, como de tocar os baixos que não têm uma extensão muito grande e também as árias cantadas que são de um canto gracioso.

A operação é bastante simples, como se verá. Será necessário portanto tocar em clave de $\mathrm{F}$ ut fá na quarta linha, assim como em clave de $\mathrm{G}$ ré sol na primeira, com esta diferença que se porá sempre as notas uma oitava abaixo da que são, tanto que isso poder-se-á fazer contudo sem fazer uma melodia desagradável. Observar-se-á também não subir, raramente, mais agudo que o ré do meio. Darei aqui alguns exemplos.

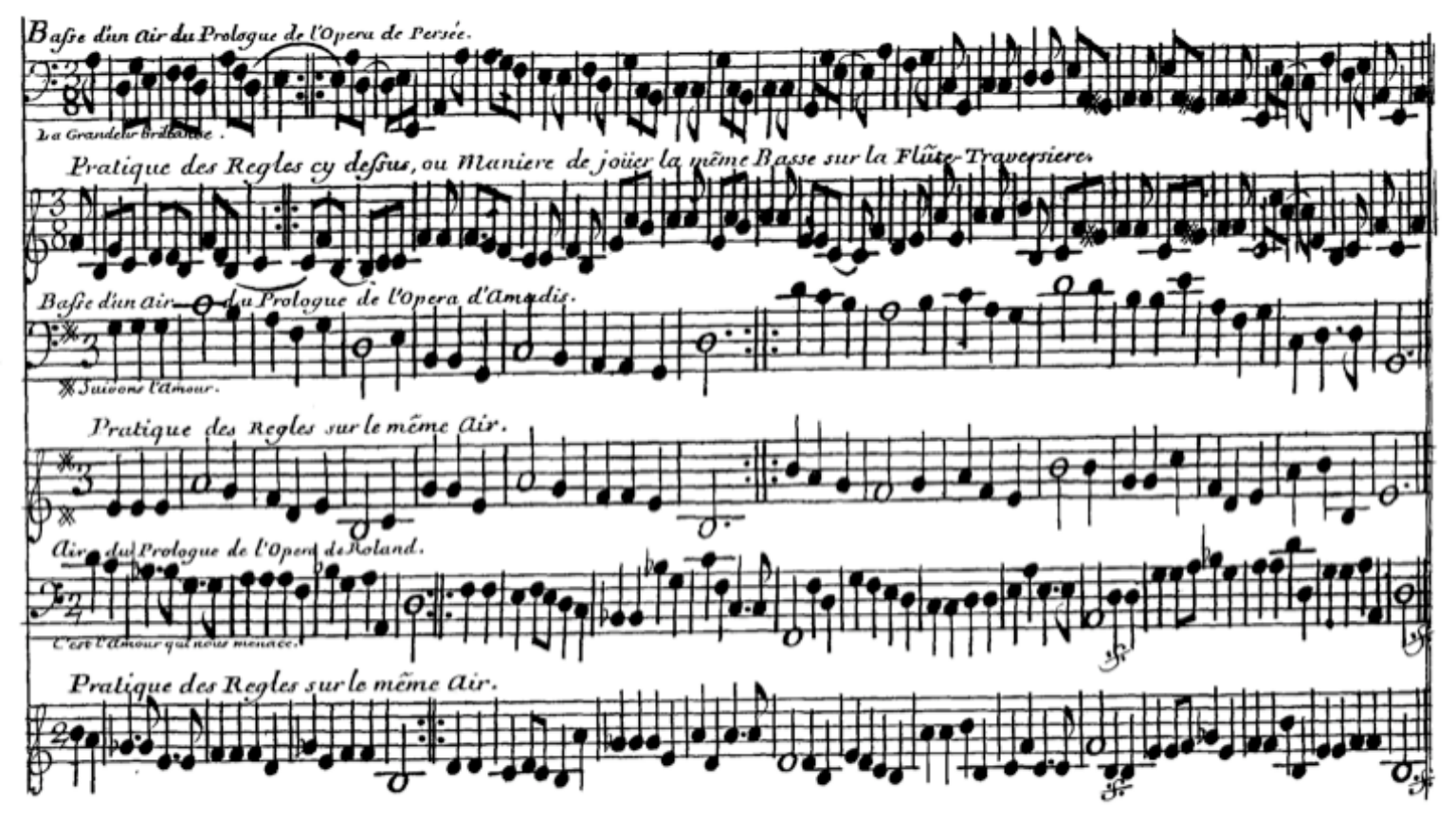

Baixo de uma ária do prólogo da ópera Persée; Prática das regras acima, ou maneira de tocar o mesmo baixo na flauta traversa; Baixo de uma ária do prólogo da ópera Amadis; Prática das regras da mesma ária; Ária do prólogo da ópera de Roland 'É o amor que nos ameaça'; Prática das regras da mesma ária.

Se se quisesse tocar alguma ária cantada que estivesse sobre essa clave e que desce abaixo do ré da terceira linha, seria necessário colocá-la a um alcance conveniente, supondo-a sobre a clave de C sol ut em primeira linha ou na de sol na segunda linha. 


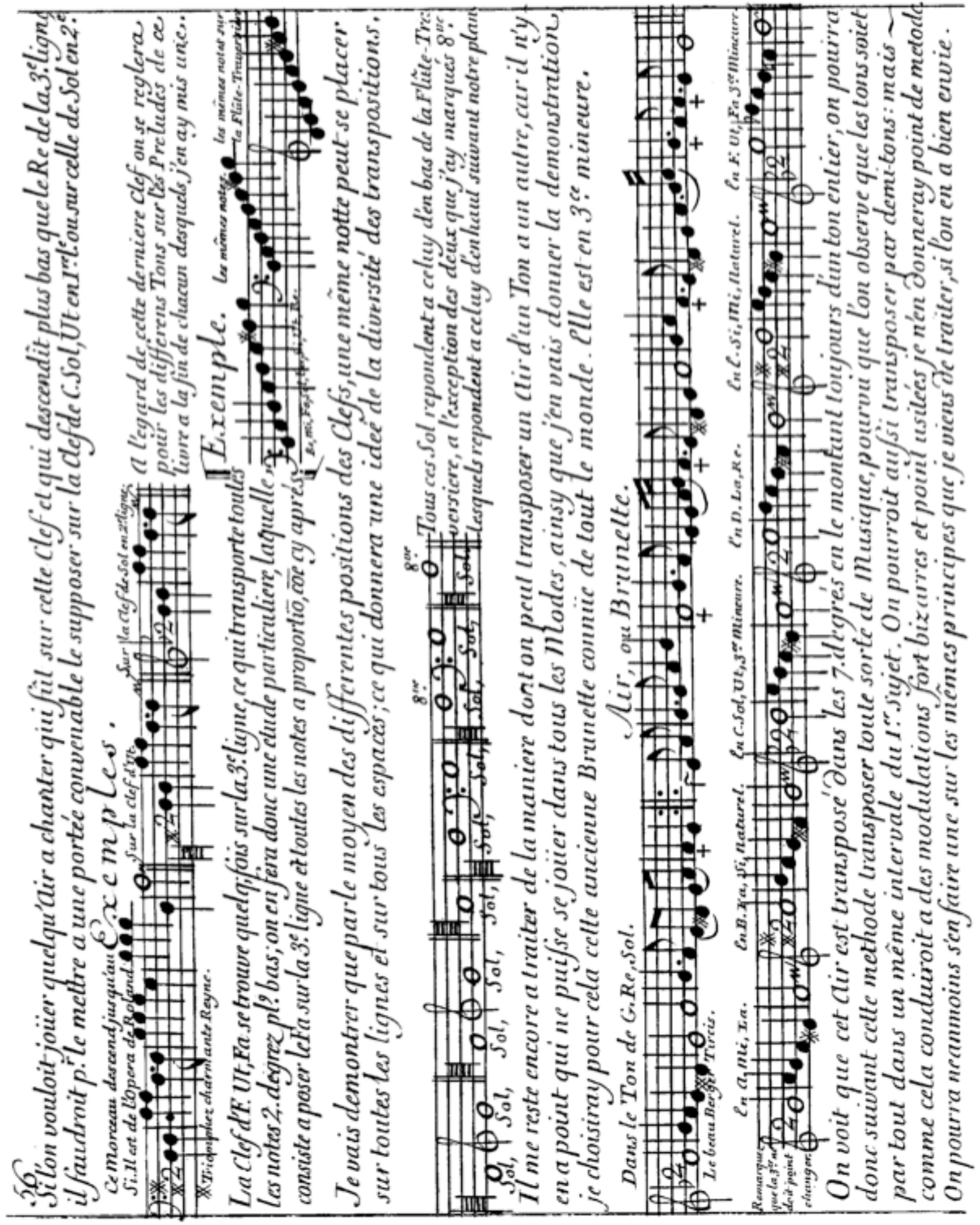




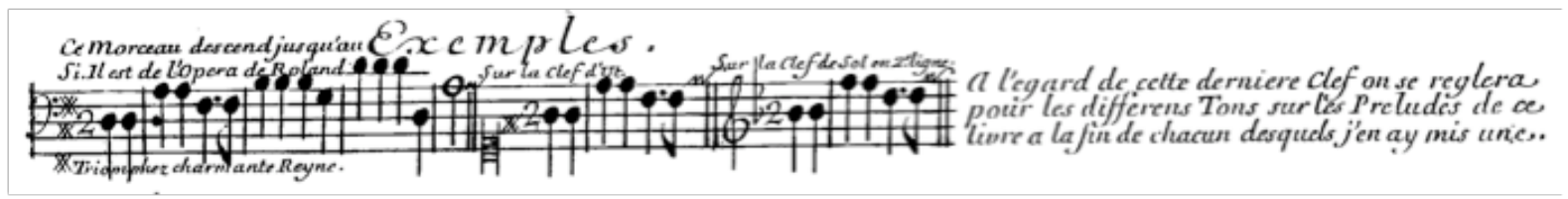

Em relação a essa última clave, ela se regulará para os diferentes tons sobre os prelúdios deste livro, ao fim de cada um dos quais coloquei uma.

A clave de $\mathrm{F}$ ut fá encontra-se às vezes sobre a terceira linha, o que transpõe todas as notas dois graus abaixo; far-se-á portanto um estudo específico, no qual consista pôr o Fá sobre a terceira linha e todas as notas à proporção, como a seguir.

Vou demonstrar que, pelo centro das diferentes posições das claves, uma mesma nota pode colocar-se sobre todas as linhas e sobre todos os espaços; o que dará uma ideia da diversidade das transposições.

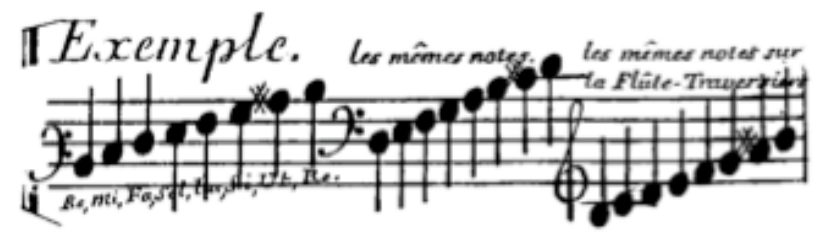

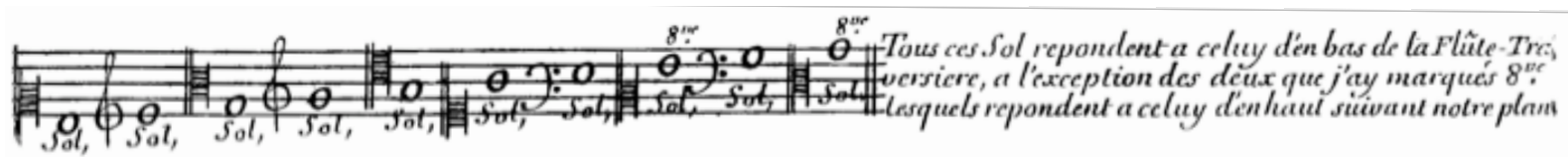

Todos os sol respondem àquele inferior da flauta traversa, com exceção dos dois que marquei oitava, os quais respondem a ele na parte superior, de acordo com o nosso plano.

Resta-me ainda tratar da maneira como se pode transpor uma ária de um tom a outro, porque não existe a que não possa se tocar em todos os modos, assim como vou dar a demonstração; escolherei para isso esta antiga Brunette ${ }^{221}$ conhecida por todos. Ela é em terça menor.

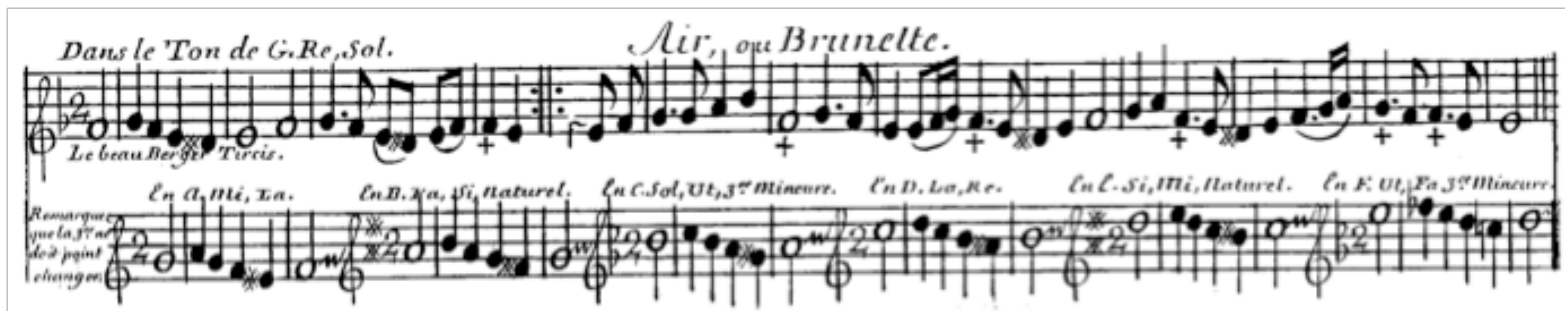

Vê-se que essa ária é transposta nos sete graus subindo sempre um tom inteiro; poder-se-á portanto, de acordo com este método, transpor qualquer espécie de música, desde que se observe que os tons estejam por toda a parte num mesmo intervalo do primeiro exposto. Poder-se-ia também transpor por semitons: mas como isso conduziria a modulações extremamente "bizarras" e não comuns, não darei como método. Poderse-á no entanto fazer um sobre os mesmos princípios que acabo de tratar, se se tiver efetivamente vontade.

221 Brunette é uma pequena canção popular a uma, duas, ou três vozes com ou sem o baixo contínuo e de estrutura geralmente bipartida em reprises (aabb). Cf. BENOIT, M. Op. cit., p.92. 


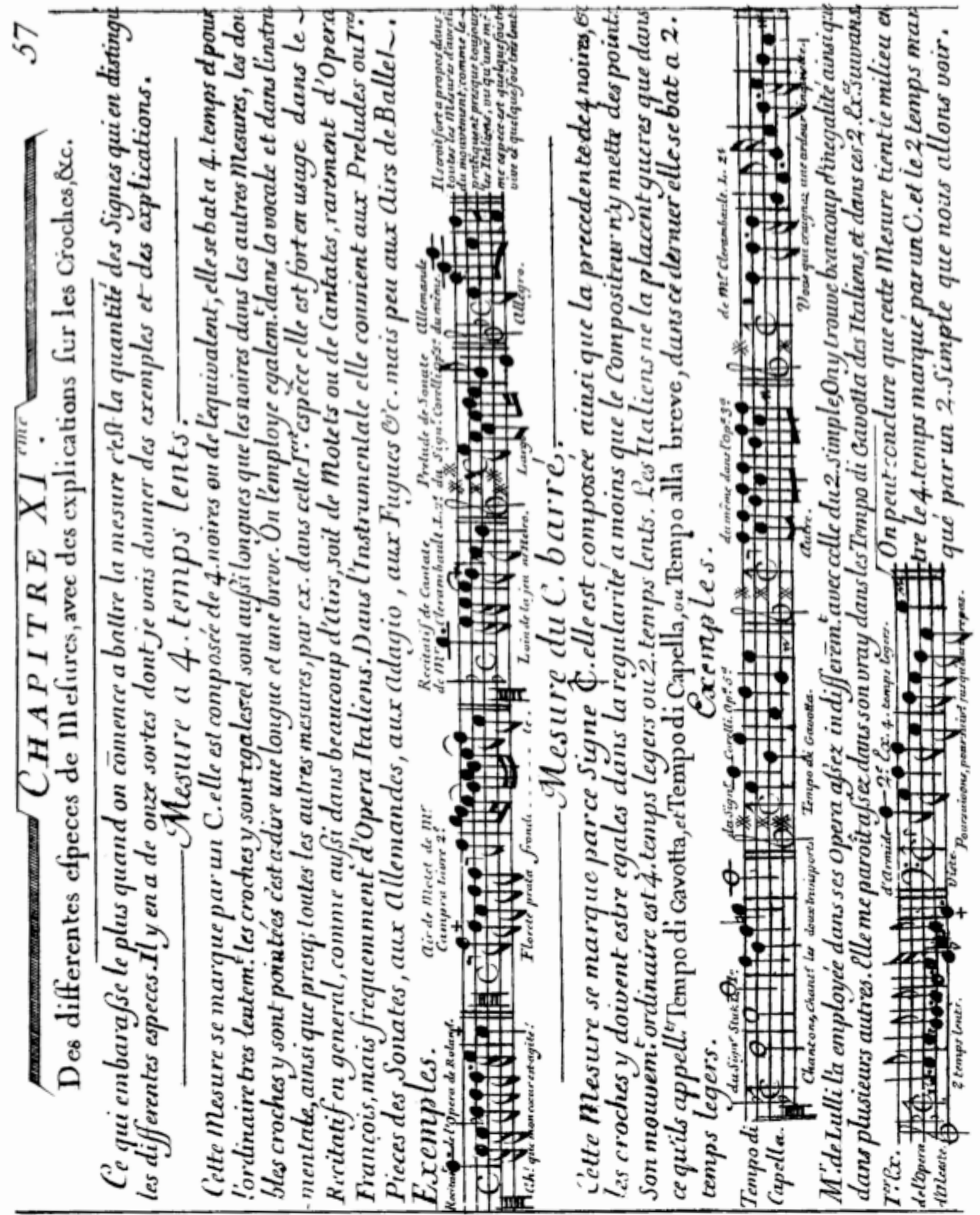




\section{Décimo Primeiro Capítulo}

\section{Das diferentes espécies de compassos, com explicações sobre as colcheias, etc..}

O que atrapalha mais quando se começa a bater um compasso ${ }^{222}$ é a quantidade dos sinais que distinguem as diferentes espécies. Existem onze espécies, das quais vou dar exemplos e explicações.

\section{Compasso de 4 tempos lentos}

\section{Este compasso se marca com um $\mathbf{C}$.}

Ele é composto de quatro semínimas ou do equivalente ${ }^{223}$, bate-se em quatro tempos e geralmente muito lentamente; as colcheias existentes são iguais ${ }^{224}$ e são tão longas quanto as semínimas nos outros compassos; as semicolcheias são pontuadas ${ }^{225}$, ou seja, uma longa e a outra curta.

Emprega-se igualmente na musica vocal e na instrumental, bem como em quase todos os outros compassos; por exemplo, nessa primeira espécie é muito usado no Recitativo em geral, como também em muitas Árias, seja dos Motetos ou de Cantatas, raramente na Opera Francesa, mas frequentemente nas Óperas Italianas.

$\mathrm{Na}$ música instrumental convém aos Prelúdios ou às primeiras peças das Sonatas, às Allemandas, aos Adagios, às Fugas etc., mas pouco às Árias de Ballet ${ }^{226}$.

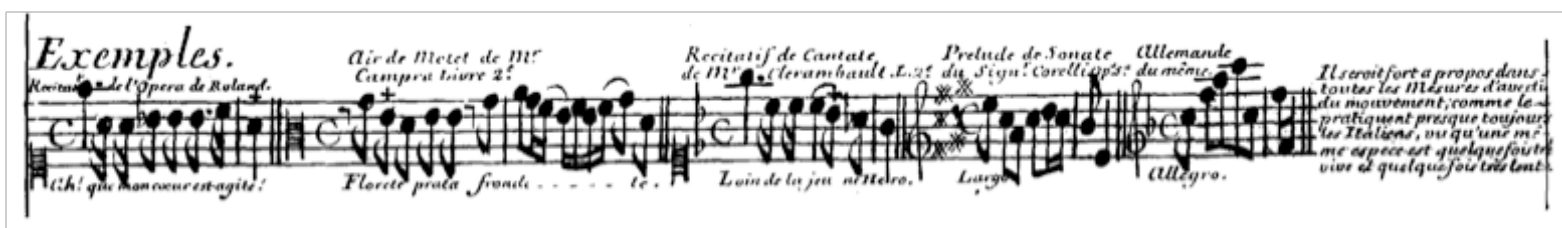

Será também oportuno, a propósito, avisar sobre o movimento de todos os compassos; como praticam quase sempre os italianos, tendo em conta que uma mesma espécie é às vezes muito viva e às vezes muito lenta.

\footnotetext{
222 A expressão 'bater um compasso' é o mesmo que pulsar a duração dos tempos de cada compasso em uma peça de música.

223 O valor equivalente que se refere Hotteterre é um conjunto de figuras musicais diferentes (mínima, colcheia, notas pontuadas etc.) de valor global igual a quatro semínimas.

${ }^{224}$ A execução possui duração igual (égale).

225 Escrita em valores iguais porém de execução pointer, desigual.

226 Sobre as Airs de Ballet cf. o primeiro capítulo deste trabalho.
} 


\section{Compasso de $\pitchfork$}

Este compasso é indicado por este sinal $\mathbb{C}$.

Ele é composto, bem como o precedente, de quatro semínimas etc.; as colcheias devem ser iguais na regularidade, a menos que o Compositor nelas coloque pontos.

O seu andamento comum é em quatro tempos ligeiros ou em dois tempos lentos.

Os Italianos o usam apenas nos chamados Tempo di Gavotta, Tempo di Cappella ou Tempo alla breve; neste último bate-se em dois tempos ligeiros ${ }^{227}$.

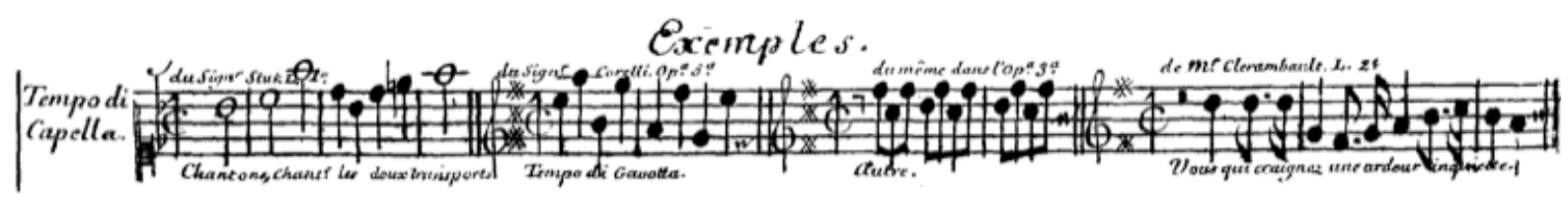

O Sr. Lulli228 empregou-o bastante nas suas Óperas, indiscriminadamente com o 2 simples.

Encontra-se [aplicada] muita desigualdade ${ }^{22}$, bem como em vários outros [compassos].

Ele me parece bem claro no Tempo di Gavotta dos Italianos e nestes dois exemplos seguintes.

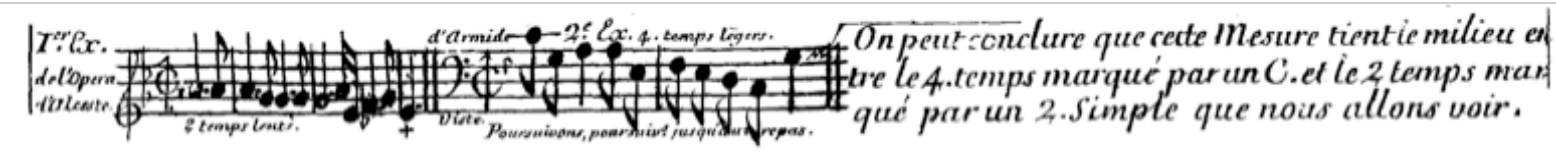

Pode-se concluir que este compasso é um meio termo entre aquele de quatro tempos marcado por um $\mathbf{C}$ e o de dois tempos, marcado por um 2 simples, que vamos ver.

227 Os termos italianos tempo di gavotta, tempo di cappella ou tempo alla breve são definidos por Brossard como uma denominação do andamento, sem se referir à forma. Hotteterre afirma que todos esses são marcados pelo sinal C (cortado), em conformidade com Brossard. Cf. BROSSARD, S. Op. cit., p. 17 e 41.

228 A grafia do nome do compositor Jean Baptiste Lully como Lulli deve-se à sua nacionalidade.

229 Pointer [inégalité]. 


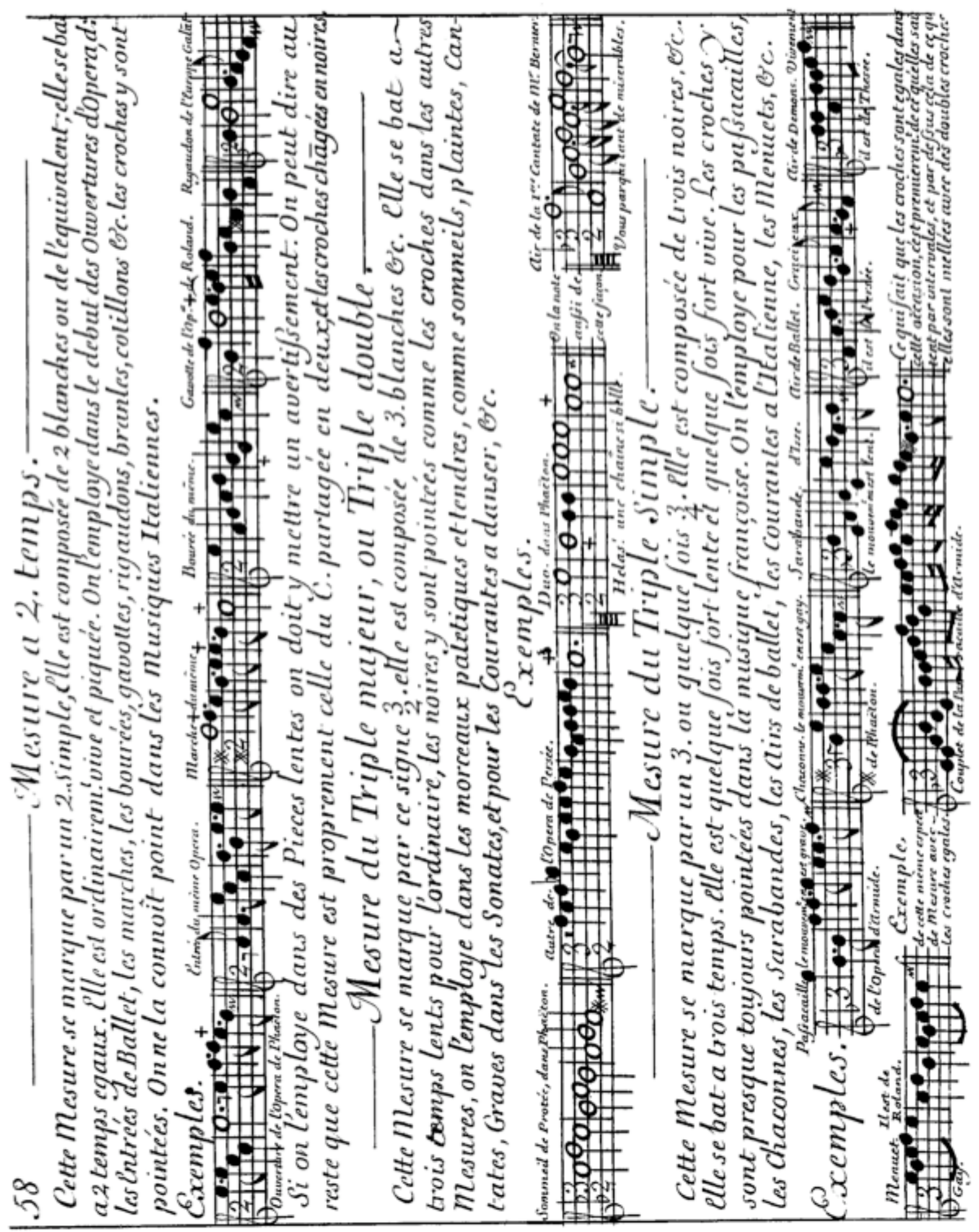




\section{Compasso de 2 tempos simples}

Este compasso é marcado por um 2 simples.

Ele é composto de duas mínimas ou de sua equivalência; ele se bate em dois tempos iguais.

Ordinariamente [o andamento] é vivo e picado ${ }^{230}$.

Emprega-se o no início das Aberturas de Ópera [ouvertures], nas Entrées de Ballet, nas Marchas, Bourrées, Gavottes, Rigaudons, Branles, Cotillons ${ }^{231}$ etc.; as colcheias são pontuadas.

Não se conhece na Música Italiana.

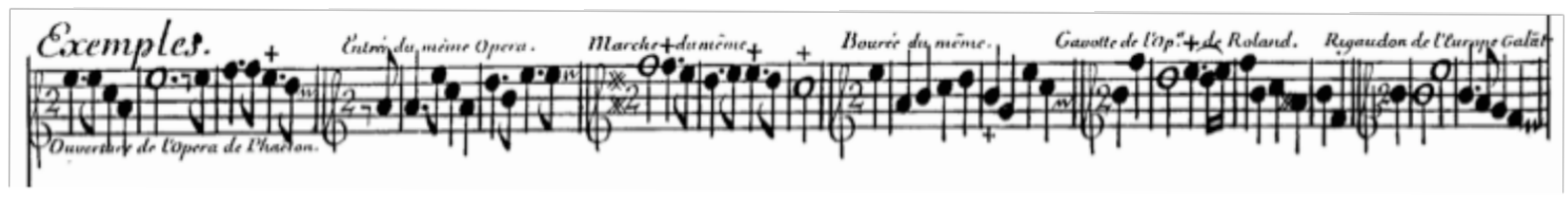

Se se o emprega em peças lentas, deve-se pôr uma advertência. Pode-se dizer de resto que esse compasso é propriamente aquele do c dividido em dois, com as colcheias corretamente alteradas para semínimas ${ }^{232}$.

\section{Compasso Triplo maior, ou Triplo duplo}

Este compasso se marca com o sinal $\mathbf{3 / 2}$.

Ele é composto de três mínimas etc.

Ele se bate geralmente em três tempos lentos, as semínimas são pontuadas ${ }^{233}$ como as colcheias nos outros compassos.

Emprega-se-o nos trechos patéticos e afetuosos, como os Sommeils, Plaintes, Cantates, nos Graves em Sonatas e para as Courantes para dançar etc. ${ }^{234}$

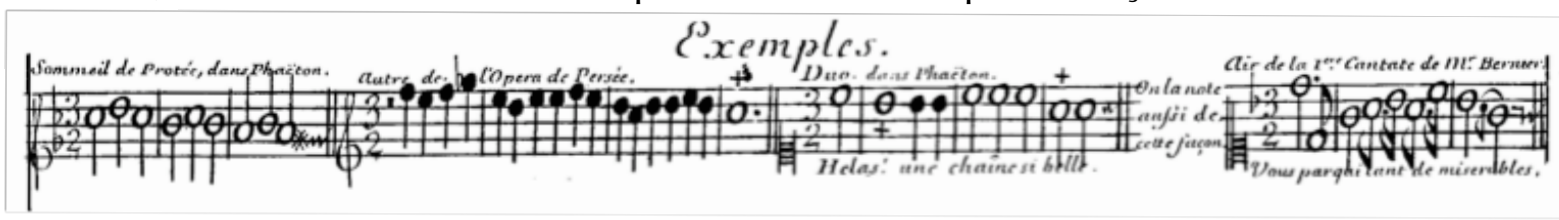

\footnotetext{
230 Entende-se por picado (piquée) uma execução desigual mais curta (cf. o primeiro capítulo deste trabalho).

231 Bourrée, Gavotte, Rigaudon, Branle, assim como outras que serão citadas mais adiante (Canarie, Passepied etc.), são todas formas encontradas na suíte de danças. O Cotillon é a versão francesa da contradança, dança de casais. A Entrée é uma peça instrumental que acompanhava a entrada dos bailarinos em cena nos ballets de Lully. Mais informações acerca das danças e das pièces de caractères no primeiro capítulo deste trabalho.

${ }^{232}$ Ou seja, com semínimas que valem meio tempo, exatamente como as colcheias no compasso $\mathbf{C}$.

233 Pointer [inégalité].

${ }^{234}$ Sommeil, episódio de um divertimento da tragédia lírica que evoca o adormecimento, o descanso ou o sonho. O seu equivalente italiano é a aria del sonno. Plainte é uma peça musical cromática, lenta, que testemunha dor ou aflição, típica da música em estilo francês. Cf. BENOIT, M. Op. cit., p. 563 e 646.
} 


\section{Compasso Triplo simples}

Este compasso se marca com um 3 ou às vezes com um $\mathbf{3 / 4}$.

Ele é composto de três semínimas etc.

Ele se bate em três tempos. É às vezes intensamente lento ou às vezes intensamente vivo.

Na música francesa as colcheias continuam quase sempre pontuadas.

Emprega-se nas Passacailles, Chaconnes, Sarabandes, nas Árias de Ballet, nas Courantes à Italiana, nos Menuets etc. ${ }^{235}$

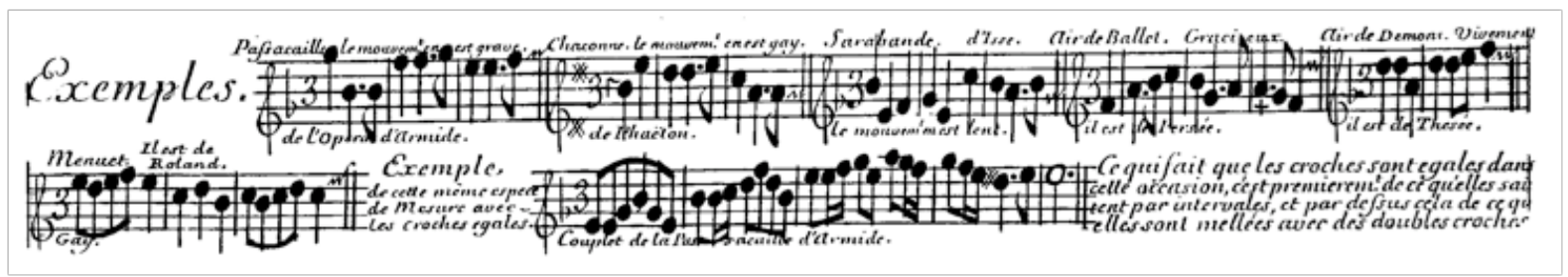

Exemplo da mesma espécie de compasso com colcheias iguais

O que faz com que as colcheias sejam iguais nesta ocasião é primeiramente que elas

saltam por intervalos ${ }^{236}$, e ainda por cima, elas são misturadas com semicolcheias.

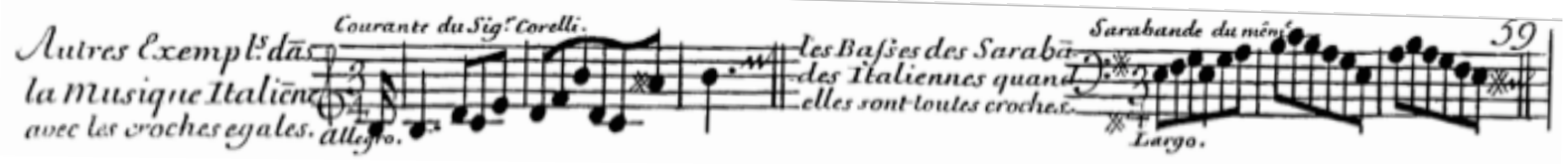

Outros exemplos da música italiana com colcheias iguais; courante do sr. Corelli.

Os baixos das Sarabandas dos italianos quando eles são todos em colcheias;

Sarabanda do mesmo autor.

235 Cf. o primeiro capítulo deste trabalho.

${ }^{236}$ Ou seja, que se movem por intervalos maiores e não por graus conjuntos. 


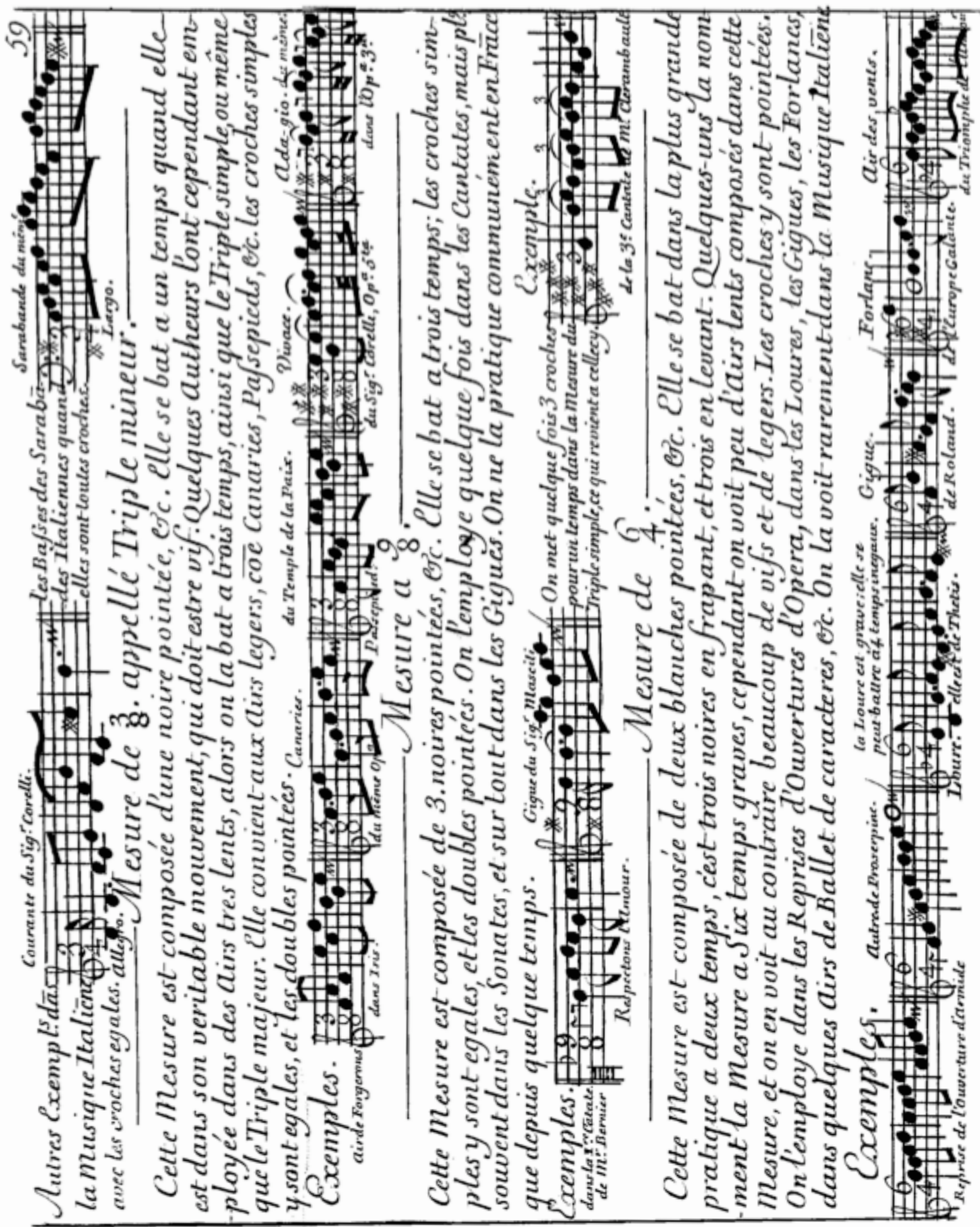




\section{Compasso de 3/8 chamado Triplo Menor}

Este compasso é composto de uma semínima com ponto etc.

Ele se bate em um tempo quando ele está no seu verdadeiro movimento, que deve ser vivo.

Alguns Autores contudo o usaram em árias muito lentas, então bate-se em três tempos, bem como o Triplo simples, da mesma maneira do Triplo Maior.

É apropriado as árias ligeiras, como a Canarie, o Passepied etc..$^{237}$

As colcheias são iguais e as semicolcheias, pontuadas.

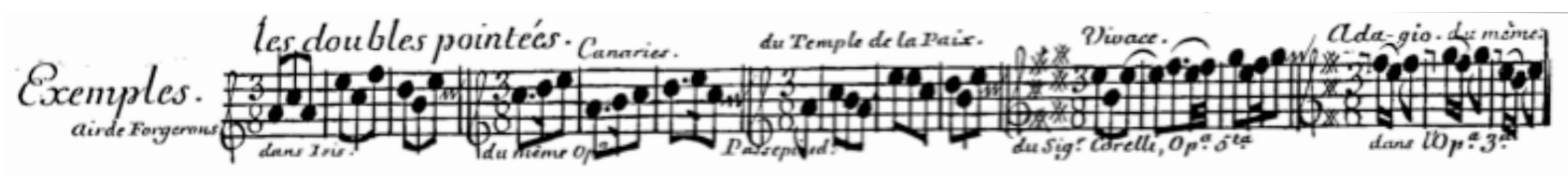

\section{Compasso 9/8}

Este compasso é composto de três semínimas com ponto ${ }^{238}$ etc.

Ele se bate em três tempos; as colcheias são iguais e as semicolcheias, pontuadas.

Usa-se-o, às vezes, nas Cantatas, mas com maior frequência em Sonatas, e sobretudo nas Gigas.

Pratica-se-o comumente na França apenas desde pouco tempo.

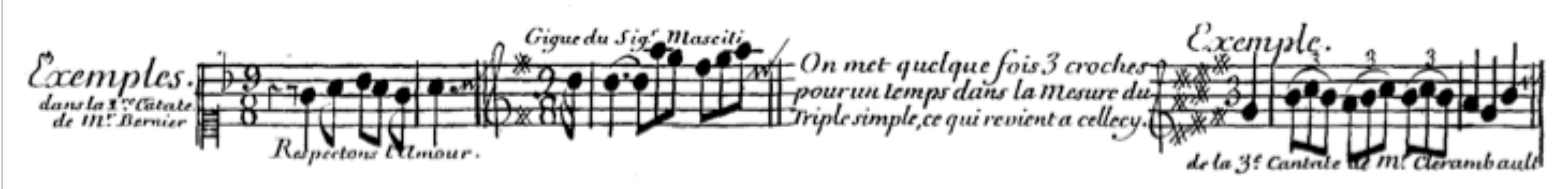

Põem-se às vezes três colcheias para um tempo na medida do triplo simples, ou seja, equivalente a este exemplo.

237 Cf. o primeiro capítulo deste trabalho.

238 Pointer. Hotteterre utiliza o mesmo termo seja para indicar a figura musical pontuada (•.; d.; etc.), seja para indicar na figura a qual é aplicada a desigualdade na execução. Nesta tradução utiliza-se o termo pontuado para o que indica desigualdade e com ponto para as figuras pontuadas. 


\section{Compasso 6/4}

Este compasso é composto de duas mínimas com ponto etc.

Bate-se na maioria das vezes em dois tempos, ou seja, são três semínimas no tempo e três en levare. Alguns o nomeiam compasso em seis tempos graves [mesure a six temps graves]; no entanto, veem-se poucas árias lentas compostas neste compasso e, ao contrário, vê-se em muitas peças vivas e ligeiras.

As colcheias são pontuadas.

Usa-se nas repetições de aberturas de Ópera [reprises d'overture ${ }^{239}$ ], nas Loures, nas Gigas, nas Forlanes, em algumas Árias de Ballet de caractères etc.

Vê-se raramente na música italiana.

A Loure é grave; pode-se bater a quatro tempos desiguais ${ }^{240}$.

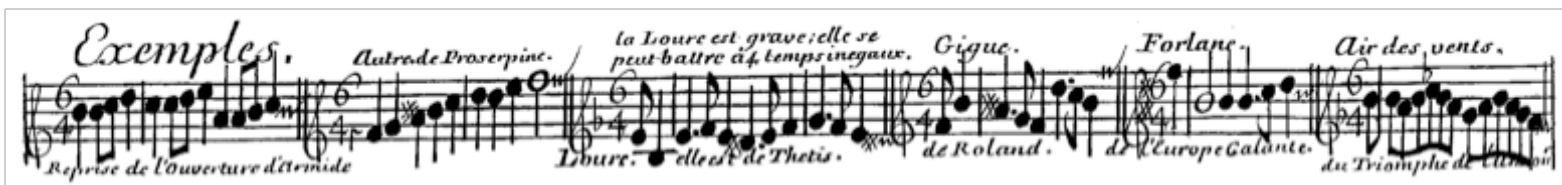

239 A parte final da Ouverture.

${ }^{240} \mathrm{~A}$ desigualdade nesse caso é acerca da pulsação $(\downarrow, \bullet ; \downarrow, \downarrow$ etc. $)$. 


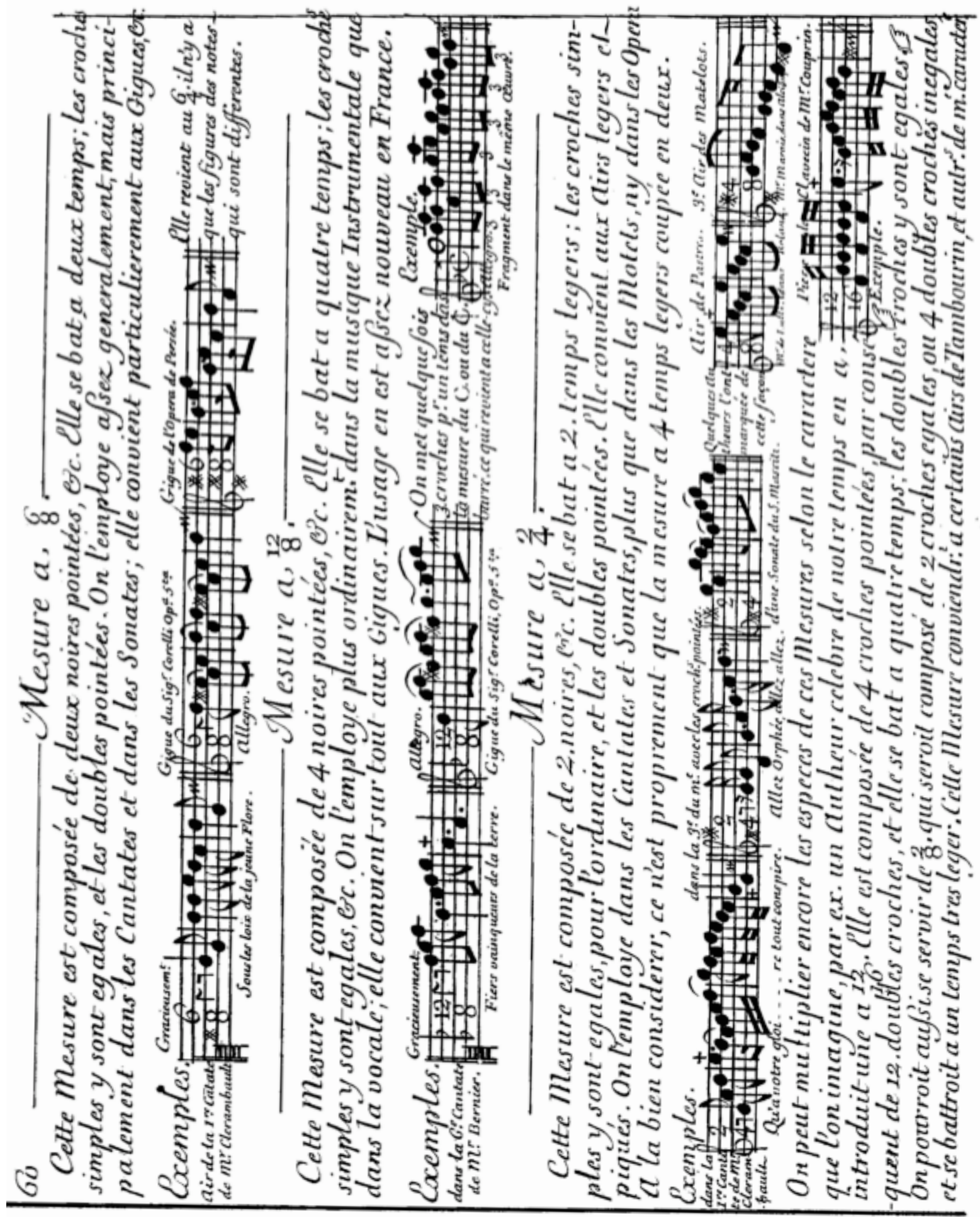




\section{Compasso 6/8}

Este compasso é composto de duas semínimas com ponto etc. pontuadas.

Bate-se em dois tempos; as colcheias são iguais e as semicolcheias são

A sua utilização é bastante generalizada, mas se usa principalmente nas Cantatas e Sonatas; é particularmente apropriado às Gigas etc.

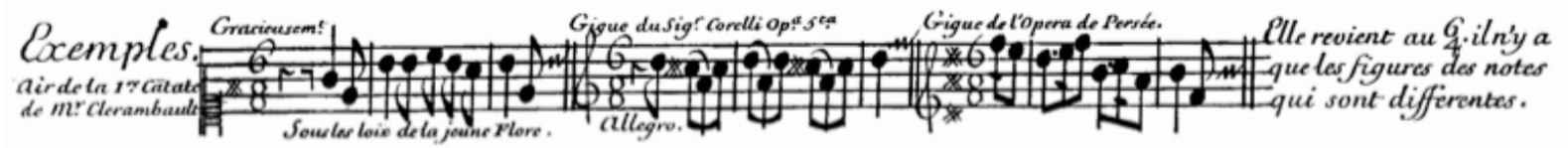

Este refere-se ao 6/4: não existem notas diferentes.

\section{Compasso 12/8}

Este compasso é composto de quatro semínimas com ponto etc.

Bate-se em quatro tempos; as colcheias são iguais etc.

Usa-se-o geralmente mais na música instrumental do que na vocal; convém sobretudo às Gigas.

Seu uso é bastante novo na França.

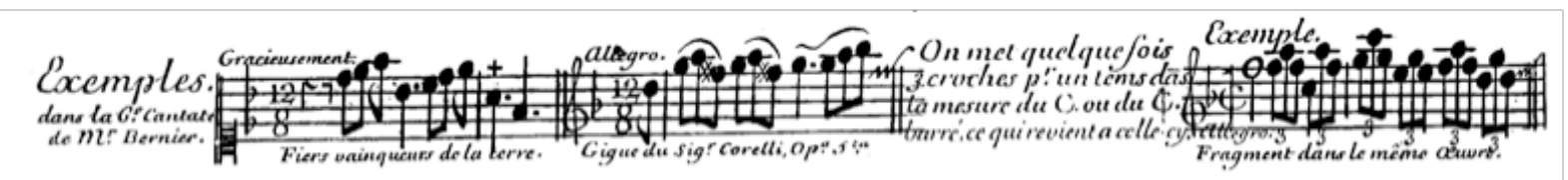

No compasso de $\mathbf{c}$ ou $\mathbf{c}$ põem-se às vezes três colcheias em cada tempo, ou seja, como se refere este exemplo.

\section{Compasso 2/4}

Este compasso é composto de duas semínimas etc.

Bate-se em dois tempos ligeiros: as colcheias são iguais, e geralmente, as semicolcheias são pontuadas.

É apropriado às árias ligeiras e picadas ${ }^{241}$.

É usado nas Cantatas e nas Sonatas mais que nos Motetos e nas Óperas.

Deve-se levar em conta que é nada mais que o compasso de quatro tempos ligeiros dividido em dois. ${ }^{242}$

241 Ver nota 230.

242 Ou seja, o compasso quaternário $\mathbf{C}$ dividido em dois tempos. 


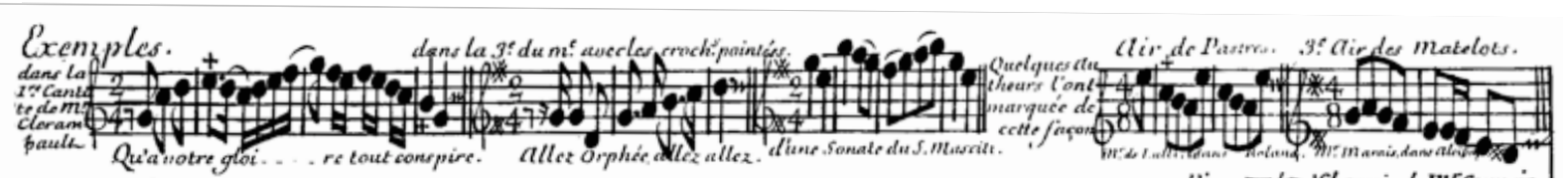

Pode-se multiplicar ainda as espécies destes compassos de acordo com o caráter que se imagina; por exemplo, um célebre autor de nosso tempo introduziu um compasso de 12/16 (é uma peça de cravo do Sr. Couperin). Ele é composto de quatro colcheias com ponto, por consequência de doze semicolcheias, e bate-se em quatro tempos; as semicolcheias são iguais.

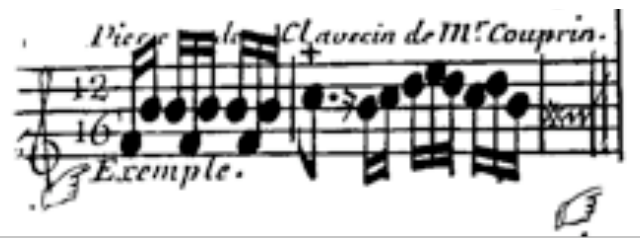

Poder-se-ia também servir-se do compasso de 2/8, que é composto de duas colcheias iguais ou de quatro semicolcheias desiguais, e se bate em um tempo muito ligeiro. Esse compasso seria apropriado a certas árias de Tambourin ${ }^{243}$ e a outras do mesmo caráter.

Exemplo do Sr. Couperin

243 Dança em ritmo binário de origem provençal caracterizada pelas notas repetidas no baixo, imitando um tambor. Mais rápida que a Bourrée e que o Rigaudon. Cf. QUANTZ, J.J. Op. cit., p.275. 


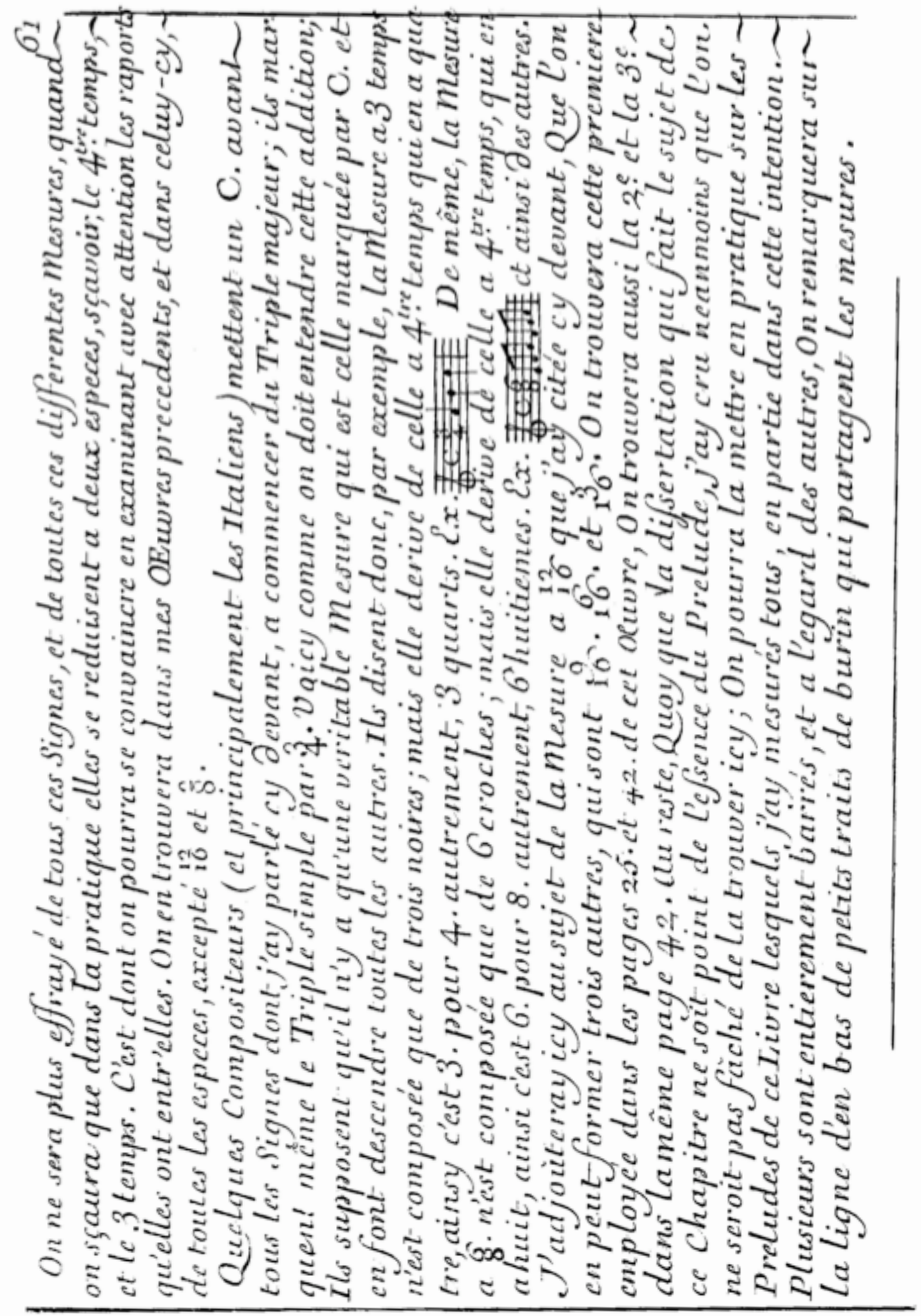


Não mais nos assustaremos com todos esses sinais, e com todos esses diferentes compassos, quando se souber que na prática eles se reduzem a duas espécies: aqueles em quatro tempos e aqueles em três tempos, dos quais poderá convencer-se examinando cuidadosamente as relações que têm entre eles. Encontrar-se-ão nas minhas obras precedentes e nesta, de todas as espécies, salvo 12/16 e 2/8.

Alguns compositores (e principalmente os italianos) põem um $\mathbf{C}$ antes dos sinais dos quais falei acima, a começar pelo Triplo Maior ${ }^{244}$; e marcam o mesmo para o Triplo Simples ${ }^{245}$ em 3/4.

Eis como se deve entender essa adição ${ }^{246}$. Supõem que há apenas um verdadeiro compasso, que é a marcado com $\mathbf{C}$, e deste fazem descender todos os outros. Dizem portanto, por exemplo, que o compasso em três tempos não é composto apenas de três semínimas; mas ele deriva daquele em quatro tempos que tem quatro, assim é 3 [semínimas] para 4 [semínimas], ou seja, três quartos ${ }^{247}$.

Do mesmo modo, o compasso

6/8 não é composto apenas de seis colcheias; mas deriva do compasso em quatro tempos, que é em oito, assim é seis [colcheias] para oito [colcheias], de outra maneira, seis oitavos.
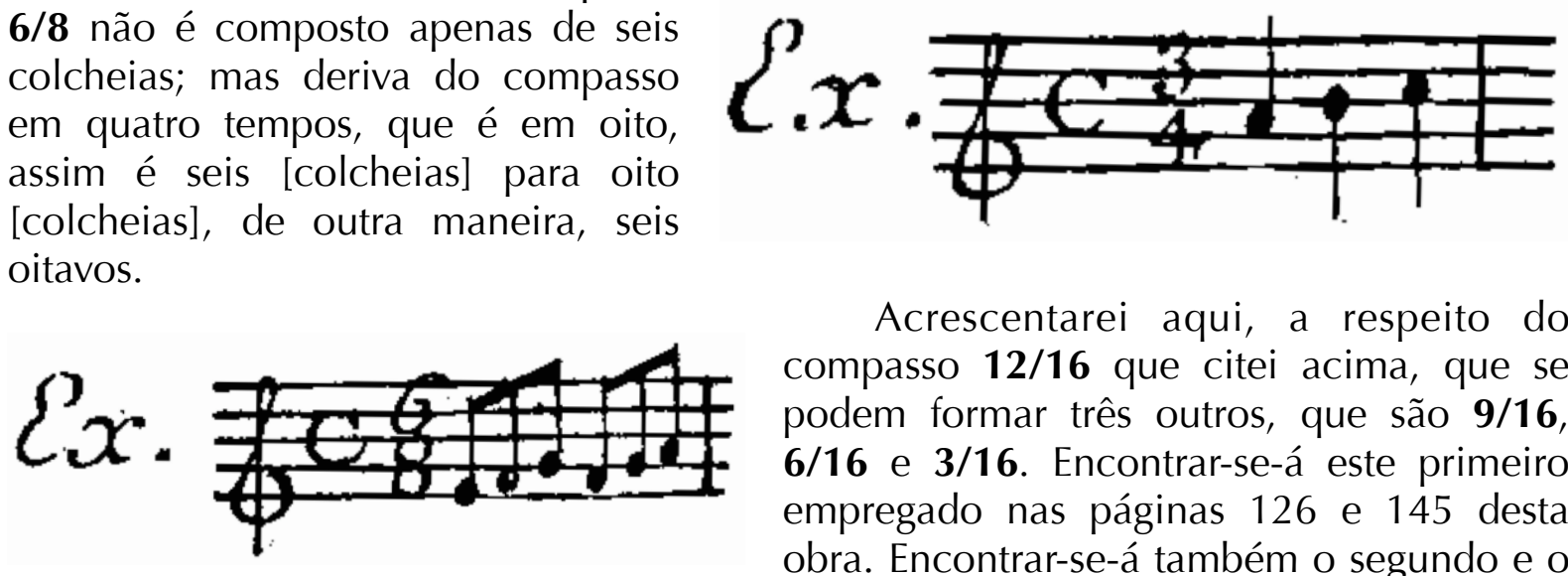

Acrescentarei aqui, a respeito do compasso 12/16 que citei acima, que se podem formar três outros, que são 9/16, 6/16 e 3/16. Encontrar-se-á este primeiro empregado nas páginas 126 e 145 desta obra. Encontrar-se-á também o segundo e o terceiro na mesma página 145.

e assim para os outros.

De resto, embora a dissertação que faz o assunto deste capítulo não seja a essência do prelúdio, eu acreditei no entanto que não é ofensa encontrá-lo aqui; poder-

\footnotetext{
${ }^{244}$ Que se marca com C 3/2. Triplo maior, ou triplo duplo, em Hotteterre é o tempo de 3/2. Na Itália com o mesmo termo de tripla maggiore vem indicando um tempo que não é mais usado na França: o 3/1; assim é conhecido por autores como Bartolomeo Bismantova, Lorenzo Penna e Antonio Bortoli. Cf. DUVAL, D. L'Art de Preluder: chapitre onzième. Itália: ERTA Itália, 2005, p. 10.

${ }^{245}$ Que se marca com C 3/4. Triplo simples segundo Hotteterre é o tempo de $\mathbf{3 / 4}$ ou $\mathbf{3}$.

246 Porque é adicionado o símbolo $\mathbf{C}$ à fração da fórmula de compasso.

247 A explicação de Hotteterre é uma tentativa de traduzir em poucas palavras a teoria das proporções, que é a base da terminologia da indicação de tempo na Itália. Duval menciona que uma simples explicação das proporções ternárias é dada por Bismantova; segundo ele, o sinal do compasso ternário é composto de dois números; o número debaixo é aquele que determina o valor da nota; e o número de cima é aquele que ensina quantas figuras são necessárias por compasso. A afirmação de Hotteterre testemunha a duração do tactus de semibreve como o valor principal. Cf. DUVAL, D. Op. cit., p. 11.
} 
se-á colocá-lo em prática sobre os prelúdios deste livro, os quais medi todos ${ }^{248}$, em parte com essa intenção. Vários são divididos em compasso inteiramente, e em relação aos outros, observar-se-ão, sobre a linha inferior, pequenos traços de cinzel que dividem os compassos ${ }^{249}$.

248 Ou seja, todos os prelúdios foram escritos respeitando os valores exatos das diversas figuras de tempo. Durante o século XVII existiram muitos casos de prelúdios escritos somente com valores de semibreves, sem indicações de tempo e sem divisões de compassos; entre estes, alguns de Louis Couperin, tio do conhecido compositor François Couperin. No L'Art de toucher le Clavecin, de 1717 (A arte de tocar o cravo), anterior à Arte de Preludiar de Hotteterre, Couperin diz que, embora nos exemplos de prelúdios do L'Art de toucher seja introduzida a divisão dos tempos, ou seja, o compasso, há no entanto, na prática, um gosto que se deve respeitar. Ele adverte que aqueles que utilizam esses prelúdios medidos devem tocá-los à vontade, sem muita precisão dos movimentos. Hotteterre adverte o mesmo e diz que os prelúdios do L'Art de Preluder, apesar de medidos, devem ser tocados de memória, sem pulsar os tempos.

249 A maior parte dos prelúdios e traits do L'Art de Preluder são escritos sem a divisão de compasso. Nesses casos, um pequeno traço vertical é colocado abaixo da primeira linha do pentagrama, indicando assim a divisão de compasso. Esse é um exemplo do caráter didático da obra de Hotteterre. Por isso, apesar da divisão de compasso, é recomendável uma execução precisa da imprecisão dos prelúdios. Esse paradoxo é sinônimo do caráter do prelúdio. Com isso, Hotteterre afirma que é recomendável um percurso de estudo que vai da execução precisa (do ponto de vista do ritmo) à execução ritmicamente livre, para que com isso o intérprete consiga chegar no resultado do próprio prélude de caprice, improvisado. 


\section{Prelúdios}

Com cadências sobre todos os graus da oitava 


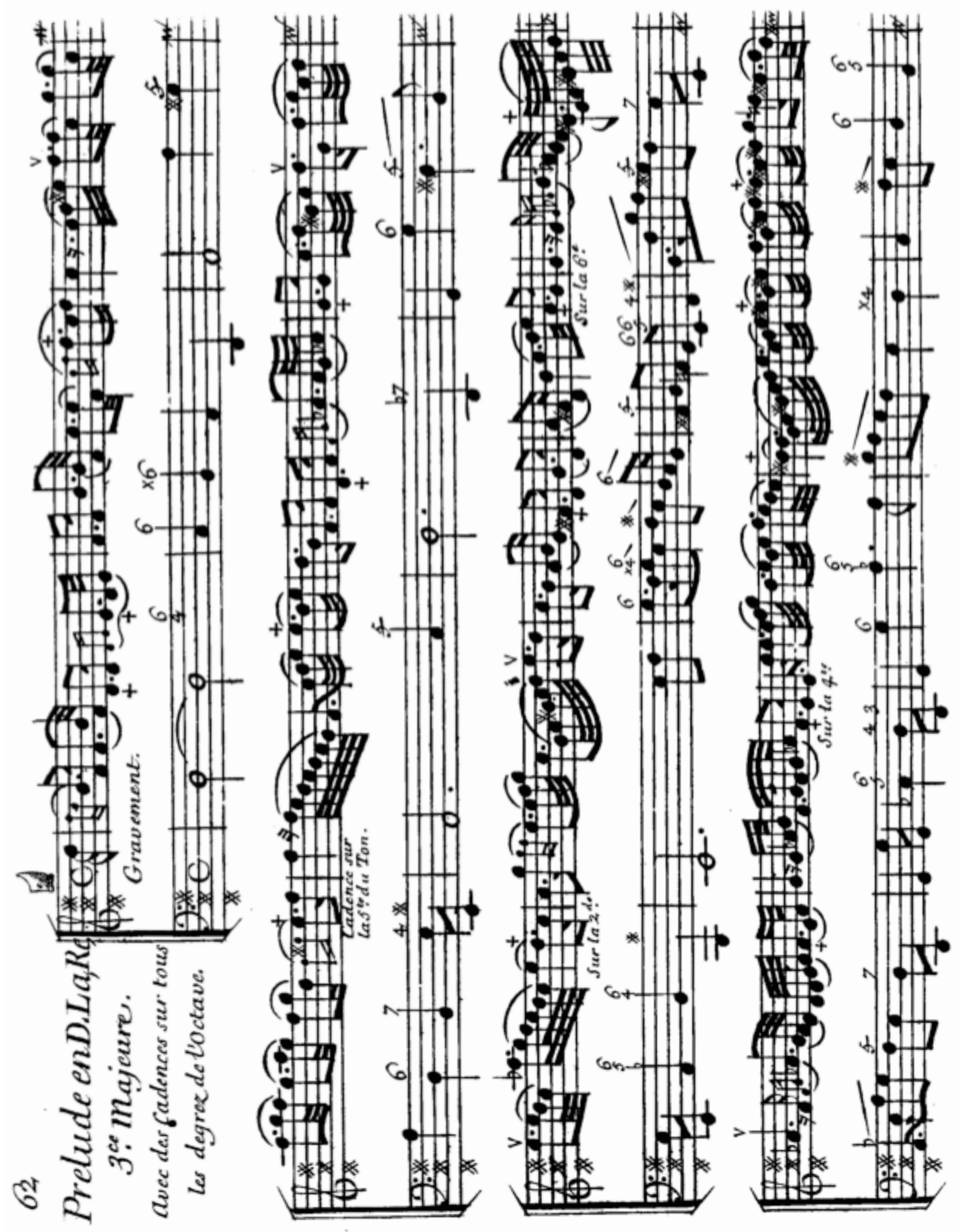




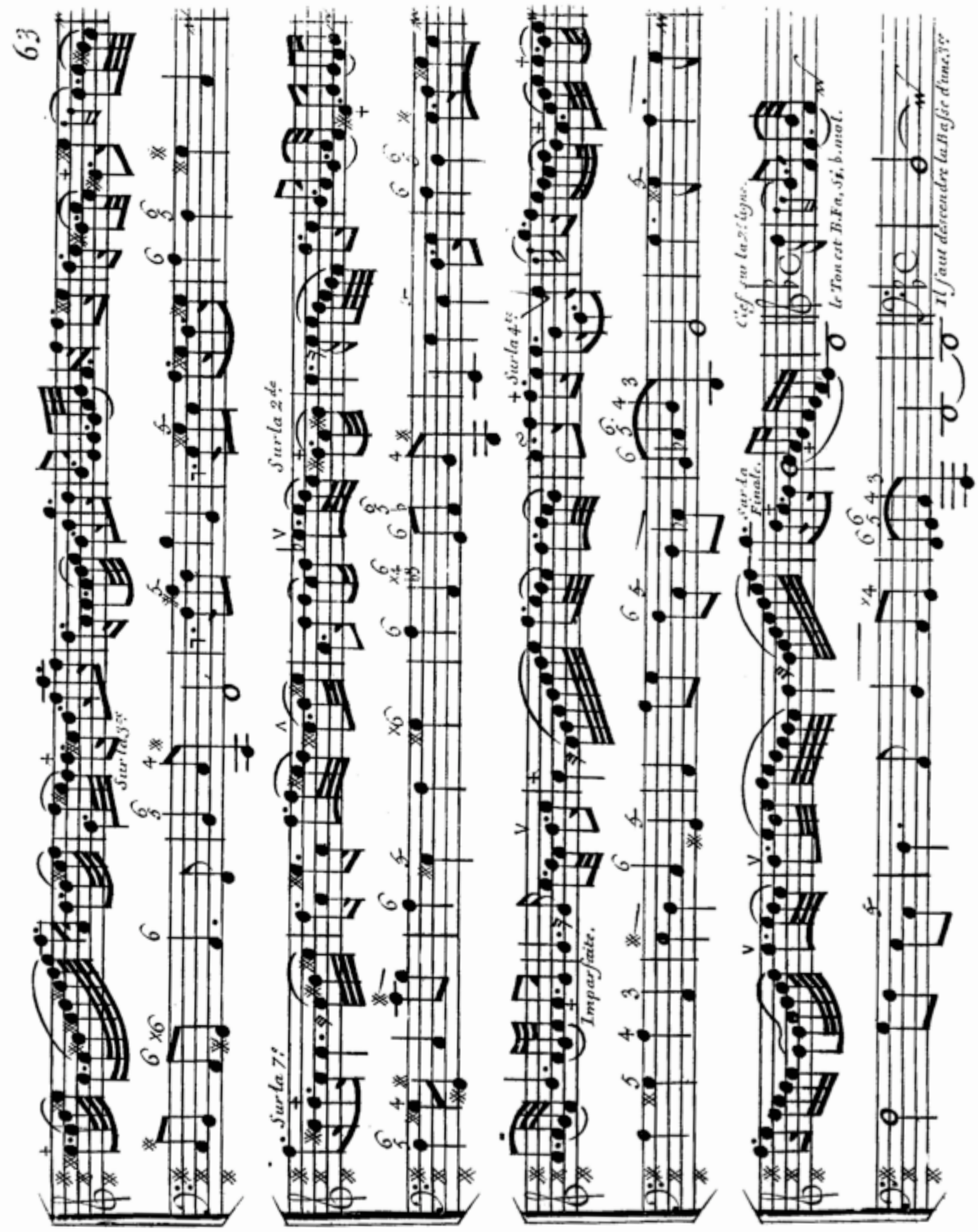




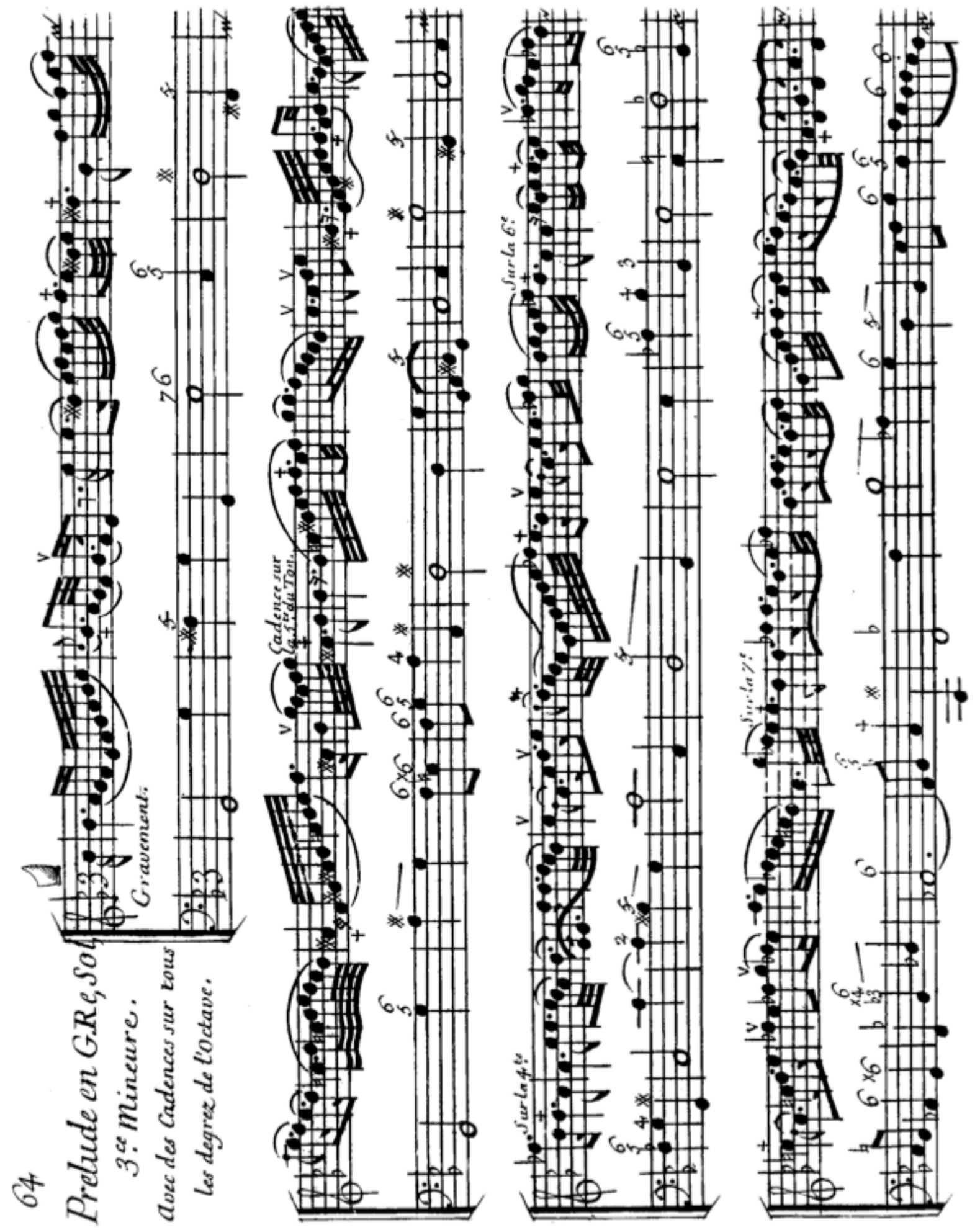




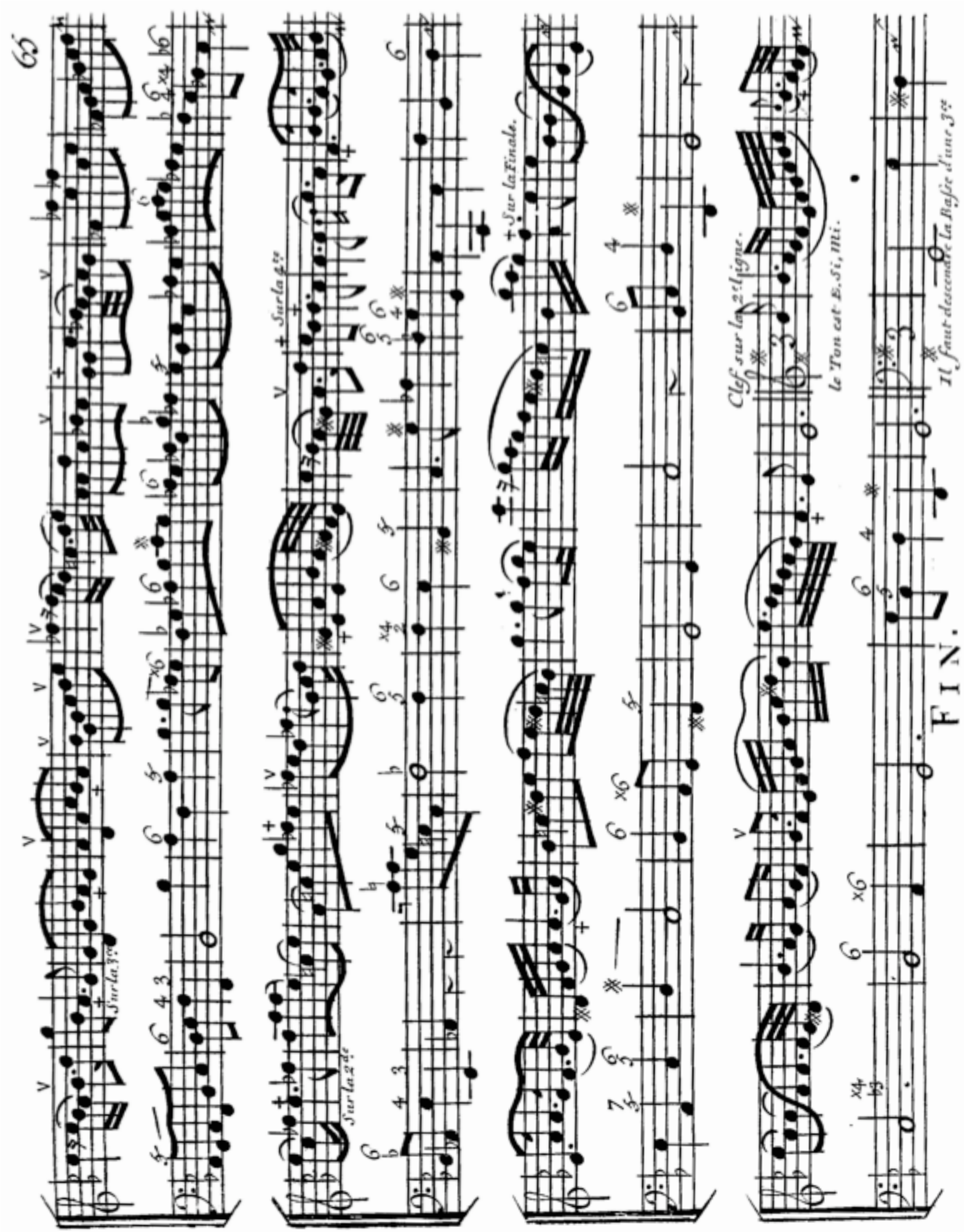





\section{CONCLUSÃO}

Jacques Martin Hotteterre - Le Romain, além de importante instrumentista, foi um excelente compositor preocupado em divulgar e ensinar as características principais de sua arte. Isso se tornou evidente nesta pesquisa, que proporcionou a confirmação de que, em uma obra significativa porém não extensa, os trabalhos didáticos de Hotteterre mantiveram uma preocupação constante em relação à utilização da flauta doce, apesar do seu instrumento principal ser a flauta traversa.

Após o Principes de la flûte traversière, com a Arte de Preludiar Hotteterre apresenta novamente uma obra mais didática que musical. Nesse tratado, o pedagogo reaparece e parece querer proteger a sua música, e em geral a música do seu tempo, contra as interpretações aleatórias dos instrumentistas que o cercavam ou que o seguiam.

A pesquisa revelou também a tradição retórica em termos utilizados por Hotteterre em toda a sua Arte de Preludiar, demonstrando como o pensamento retórico se fez presente na música francesa; enquanto na Alemanha proliferavam os tratados dedicados à musica poetica, na França surgiam predominantemente obras práticas.

Através dessa tradição, vimos que arte diz respeito às ideias de imitação e do exercício, os princípios fundamentais do aprendizado da retórica. Isso, na Arte de Preludiar em particular, diz respeito a um conjunto de preceitos experimentados através da prática e de regras fundadas a partir da consideração metódica e racional da prática. Assim, remetemo-nos aos termos utilizados por Hotteterre, como princípios, regras, método e o verbo instruir, aliados à prática de prescrever e demonstrar, fundamentais à instrução de "como preludiar" objetivada por Hotteterre. Para tanto, Hotteterre procede, justamente, bastante metodicamente; daí a importância do emprego de um caneva e de um trait.

O contato aprofundado com o tratado de Hotteterre revelou também que a variedade deve fazer parte dessa arte. Ela é a qualidade essencial do estilo que, para não ser tedioso nem soporífico, deve sempre variar.

Sobre a variedade, Hotteterre menciona o termo francês figuré, que pode ser traduzido como figurado (termo retórico) ou ornamentado (termo em música). Tanto um termo quanto o outro jogam com a exploração das possibilidades de 
transformação; com isso, o variar dentro dos códigos (prescrito) e o variar inovando (oferecendo outros elementos) são integrantes da noção de variedade de Hotteterre.

Com relação ao pensamento harmônico de Hotteterre, podemos perceber que a circulação de um modo para outro foi guiada pelas considerações tonais. Hotteterre escolhe tons próximos no círculo das quintas, obedecendo a uma prática setecentista de não se afastar muito do centro tonal. Enquanto no segundo capítulo, "Des éléments du prélude", não há qualquer menção à possibilidade de se modular durante o prelúdio, o oitavo capítulo, "Explication sur les cadences, et sur la distribution que l'on en doit faire dans les modes majeur et mineur", trata de modulações possíveis e da sua distribuição.

A respeito da problemática da desigualdade de notas igualmente notadas, concluímos que existe uma utilização inadequada do termo inégalité, pois o próprio Hotteterre, em seu tratado, deixa clara a utilização do termo pointer para representar a desigualdade que atualmente denominamos inégalité.

Acerca do objeto da Arte de Preludiar de Hotteterre, esta pesquisa revelou que o uso do termo capricho para qualificar o prelúdio improvisado é significativo, e uma investigação mais detalhada desse termo nos trouxe informações úteis. Com a designação prélude de caprice, Hotteterre uniu características do prelúdio às do capricho. Ele acoplou a improvisação própria do prelúdio à liberdade do engenho típica do capricho. Com isso, tornou claros os fundamentos de sua Arte.

A despeito da predominância do engenho nos caprichos, a disposição natural relacionada à variedade do prelúdio, vimos que Hotteterre considera que o prelúdio de capricho não é fruto apenas da inspiração, como se faria romanticamente supor. Para ele, mesmo a improvisação, o gênero musical menos dependente das regras da arte, está sujeita a leis que possibilitam que ela seja persuasiva e que a tornam ensinável.

Este trabalho mostrou que a técnica de improvisação proposta por Hotteterre não se baseia apenas em elementos franceses (desigualdade rítmica, ornamentos fixos etc.). Ela utiliza também elementos italianos como os ornamentos livres, denomimados passagens por Brossard. Esse fato permitiu conhecer uma nova dimensão da influência italiana na música francesa do início do século XVIII. Assim, a experiência cultural de Hotteterre é revelada em sua obra e, no caso do L'Art de Preluder, é aparente na sua matéria, canevas e traits. 
A pesquisa ainda nos revelou que o movimento e o caráter dos modos utilizados por Hotteterre são semelhantes às definições atribuídas às tonalidades por Charpentier em seu Règles de Composition anterior à Arte de Preludiar.

Concluindo este trabalho, podemos perceber que a enorme importância do L'Art de Preluder se dá por todos os elementos descritos acima. A obra não constitui apenas um conjunto de peças para serem estudadas, mas em uma série de exemplos para serem imitados, constituindo assim uma fonte riquíssima para o estudo da música instrumental setecentista. 



\section{BIBLIOGRAFIA}

\section{Fontes Primárias}

ARISTÓTELES. Ética a Nicômacos. Brasília: UnB, 1985. Retórica. Madrid: Gredos, 1974.

ACADÉMIE FRANÇAISE. Nouveau dictionnaire de l'Académie Françoise. Paris: J.B. Coignard, 1718. http://gallica.bnf.fr/ark:/12148/bpt6k504003. Acesso em 12 de dez 2008.

BLAINVILLE, C. H. L' esprit de l'art musical. ou Réflexions sur la musique, et ses différentes parties (Genebra, 1754). Edição fac-similar. Genebra: Minkoff, 1974.

BROSSARD, Sébastien de. Dictionnaire de Musique (Amsterdam, 1708, 3 ed.). Paris: Minkoff, 1992.

CALLOT, J. Capricci. Nancy, 1621/1622. http://collection.aucklandartgallery.govt.nz. Acesso em: 02 de jan 2009.

CORRETTE, M. Méthode pour apprendre aisément à jouer de la flûte traversière (Paris, 1735). Amsterdam: U.Frits Knuf Buren, 1978.

DALLA CASA, G. I/ vero modo di diminuir con tutte le sorti di stromenti di fiato, \& corda, \& di voce humana (Veneza, 1584). Edição fac-similar, Bologna: Arnaldo Forni Editore, 1970.

D'ALEMBERT, J. Le Rond. Eléments de Musique (Paris, 1752). Genebra: Slatkine Reprints, 1980.

DE LA VIÉVILLE, Le Cerf. Comparaison de la musique italienne et de la musique française I-III (Bruxelas, 1705/6). Genebra: Minkoff, 1972.

Dictionnaire universel françois et latin, vulgairement appelé Dictionnaire de Trévoux: contenant la signification et la définition des mots de l'une et de l'autre langue. Paris: Compagnie des libraires associes, 1771. http:// gallica2.bnf.fr/ark:/12148/bpt6k50980z. Acesso em: 19 de fev 2008.

DIRUTA, G. II Transilvano (Venezia, 1593). Edição fac-similar. Bologna: Arnaldo Forni Editore, 1997. 
DUVAL, L'Abbé P. Principes de la Musique Pratique. Paris, 1764. http:// www.scribd.com/doc/96816/Principes-de-la-Musique-Pierre-Duval. Acesso em: 03 de jan 2009.

FREILLON-PONCEIN, J.P. La veritable maniere d'apprendre en perfection a joüer du haut-bois, de la flûte et du flageolet, avec les principes de la musique pour la voix et pour toutes sortes d'instrumens (Paris, 1700). Paris: Fuzeau Classique, 2006 (Méthodes e Traités: Flûte à Bec Europe 1500-1800, Volume IV).

FURETIÈRE, A. Dictionaire Universel: Contenant generalement tous les mots François, tant vieux que modernes, e les termes de toutes les sciences e des arts. La Haye : A. et R. Leers, 1690. http://gallica.bnf.fr/. Acesso em: 19 de fev 2009.

GANASSI, S. Opera Intitulata Fontegara (Veneza, 1535). Berlim: Robert Lienau, 1959.

HOTTETERRE, J. M. L'Art de Préluder sur la flûte traversière, sur la flûte à bec, sur le hautbois et autres instruments de dessus (Paris, 1719). Genebra: Minkoff, 1978.

- L'Art de Préluder sur la flûte traversière, sur la flûte à bec, sur le hautbois et autres instruments de dessus (Paris, 1719). Paris: Editions Aug. Zurfluh, 1966.

L'Art de Préluder sur la flûte traversière, sur la flûte à bec, sur le hautbois et autres instruments de dessus (Paris, 1719). Florença: S.P.E.S., 1999.

- Pièces pour la Flûte traversière, et autres instruments avec la bassecontinue. Livre Premier (Paris: Ballard, 1708). Edição fac-smile. Florença : S.P.E.S., 1980.

Principes de la Flûte Traversière (Paris: Ballard, 1707). Edição facsimilar. Genebra: Minkoff, 1973.

Principes de la Flûte Traversière (Paris: Ballard, 1707). Edição facsimilar. London: Barrie e Rockliff, 1968.

. Principes de la Flûte Traversière (Paris: Ballard, 1707). Edição facsimilar. New York: Dover Publications, 1968.

The Rudiments or Principles of the German Flute. London: Walsh e Hare, 1729. Reedição: ?

Première Suite de Pièces a deux dessus, sans basse continue (Paris, 1712). Edição fac-similar. Genebra: Minkoff, 1991.

. Deuxième Suite de Pièces a deux dessus (Paris, 1717). Edição facsimilar. Genebra: Minkoff, 1991. 
- Troisième Suite de Pièces a deux dessus (Paris, 1722). Edição facsimilar. Genebra: Minkoff, 1991.

Méthode pour la musette (Paris, 1737). Edição fac-similar. Genebra: Minkoff, 1978.

- Pièces pour la muzette qui peuvent aussi se jouer sur la flûte, sur le haubois, etc... (Paris, 1722). Edição fac-similar. Genebra: Minkoff, 1993.

. Airs et brunettes à deux et trois dessus pour les flûtes traversières tirez des meilleures autheurs, anciens et modernes (Paris, 1721). Edição facsimilar. Genebra: Minkoff, 1991.

LACOMBE, J. Dictionnaire portatif des beaux-arts, ou Abrégé de ce qui concerne l'architecture, la sculpture, la peinture, la gravure, la poésie et la musique. Paris: vve Estienne et fils et J.-T. Hérissant, 1752. http://gallica.bnf.fr/. Acesso em: 10 de jan 2009.

LOULIÉ, E. Eléments ou principes de musique mis dans un nouvel ordre (Paris. 1696). Edição fac-similar, Genebra: Minkoff, 1977.

MERSENNE, M. Harmonie universelle, contenant la théorie et la pratique de la musique. Paris: S. Cramoisy, 1636. http://gallica2.bnf.fr/ark:/12148/ bpt6k123738q. Acesso em: 19 de Fev de 2009.

QUANTZ, J.J. Versuch einer Anweisung die Flöte traversière zu spielen (Berlin, 1752). Trad. E. R. REILLY. On Playing the flute. Boston: Northeastern University Press, 2001.

RAMEAU, J. P. Traité de L'Harmonie (Paris: Ballard, 1722). Edição fac-similar. Paris: Méridiens Klincksieck, 1986.

RIPA, C. Iconologia. (Perugia: Stamperia di Piergiovanni Costantini, 1764) (volume I). http://books.google.com.br/books?id=4TQGAAAAQAAJ. Acesso em: 01 de abr 2009.

ROUSSEAU, J. J. Carta sobre a música francesa (Paris, 1753). Tradução de José Oscar de Almeida Marques e Daniela de Fátima Garcia. Campinas: IFCHUnicamp, 2005. http://www.ifch.unicamp.br/pub/ampliada.php? id_livro=288\&id_serie=15. Acesso em: 24 de mar de 2009 .

SAN JUAN, J. H. de. Examen de ingenios para las ciencias (Baeza: Juan Bautista de Montoya, 1575/1594). http://www.cervantesvirtual.com/. Acesso em: 05 de abr 2009.

THOINAN, E. Les Hotteterre et Les Chédeville (Paris: Edmond Sagot, 1894). Edição facsimilar. Paris: Editions Aug. Zurfluh,? 


\section{Fontes Secundárias}

ANDRADE, A. A Presença da Flauta Traversa em Portugal de 1750 a 1850. Portugal: Universidade de Aveiro, 2005. http://www.meloteca.com/tese-flautatraversa-alexandre-andrade.htm. Acesso em: 10 de mar 2008.

ANTHONY, J.R. French Baroque Music from Beaujoyeulx to Rameau. Portland, Oregon: Amadeus Press, 1997.

BEAUSSANT, P. Vous avez dit "Baroque"? França: Actes Sud, 1988.

BENOIT, M. Dictionnaire de La musique en France aux XVIle et XVIIle siècle. Paris: Fayard, 1992.

BOND, A. A Guide to the Harpsichord. Portland, Oregon: Amadeus Press, 1997.

BORREL, E. Les notes inégales dans I'ancienne musique française. Revue de Musicologie, T. 12e, №. 40e. França: Société Française de Musicologie, Nov., 1931.

BOUISSOU, S. Vocabulaire de la musique baroque. Montrouge: Minerve, 1996.

BUKOFZER, M. F. Music in the Baroque Era - From Monteverdi to Bach. New York: W.W. Norton Company, 1947.

BYRT, J. Some new interpretations of the notes inégales evidence. Early Music. U.S.A: Fev, 2000.

CANO, R. L. Música y Retórica en el Barroco. México: Universidad Nacional Autónoma de México, 2000.

DART, T. Interpretação da Música. São Paulo: Martins Fontes, 1990.

DONINGTON, R. Baroque Music: Style and Performance. New York: W. W. Norton, 1982.

DUVAL, D. L'Art de Preluder: chapitre onzième. Itália: ERTA Itália, 2005.

GEOFFROY-DECHAUME, A. Les Secrets de la Musique Ancienne: Recherches sur I'interprétation. França: Fasquelle, 1983.

GROUT, D. J. e PALISCA, C. V. História da Música Ocidental. 4 ed. Lisboa: Gradiva, 2007.

HARNONCOURT, N. O Discurso dos Sons: Caminhos para uma nova compreensão musical. Rio de Janeiro: Jorge Zahar Ed., 1998.

HAYNES, B. The Eloquent Oboe: A History of the Hautboy from 1640 to 1760. New York: Oxford University Press, 2001. 
HOUAISS. Dicionário Houaiss da Língua Portuguesa. Rio de Janeiro: Editora Objetiva, 2001.

HOUSE, D. L. Jacques Hotteterre 'Le Romain': A study of his life and compositional style. Chapell Hill: The University of North Carolina at Chapell Hill, 1991.

HUNT, E. The Recorder and its music. Londres: Herbert Jenkins, 1962.

JANSEN, S. Cos'è, nella fattispecie, il canovaccio? Appunti sul «Teatro delle favole rappresentative» di Flaminio Scala. Revue Romane, Bind 25, 1990. http:// www.tidsskrift.dk/. Acesso em: 05 de jul 2009.

LASOCKI, D. The Recorder in print: 2004. American Recorder Magazine, edição de Maio de 2006. U.S.A: American Recorder Society, 2006.

LUCAS, M. Retórica e Estética na música no século XVIII. Revista ArtCultura, v. 9, n. 14. Uberlândia: UFU, 2007.

MATHER, B. B.; LASOCKI, D. Free Ornamentation in Woodwind Music 1700-1775: an Anthology with Introduction. New York: McGinnis \& Marx, 1976.

MATHER, B.B. Interpretation of French Music from 1675 to 1775: for woodwind and other performers. New York: McGinnis e Marx, 1973.

MOLINIÉ, G. Dictionnaire de Rhétorique. Paris: Librairie Générale Française, 1992.

RANUM, P. M. Tu-Ru-Tu and Tu-Ru-Tu-Tu: Toward an Understanding of Hotteterre's Tonguing Syllables. The Recorder in the Seventeenth Century: Proceedings of the International Recorder Symposium. Utrecht: STIMU Foundation for Historical Performance Practice, 1995.

. The harmonic orator: the phrasing and rhetoric of the melody in French baroque airs. New York: Pendragon Press, 2001.

ROWLAND-JONES, A. The Baroque Recorder Sonata. In: THOMSON, J. M. (Ed.). The Cambridge Companion to the Recorder. New York: University of Cambridge, 1995.

SALVATORE, D. A proposito della Troisième Suitte di Hotteterre: alcune precisazioni. I quaderni dell'ERTA, n. 9, Março, 2006. http://www.ertaitalia.it/. Acesso em: 13 de mar 2009.

TARLING, J. The Weapons of Rhetoric. A guide for musicians and audiences. London: Corda Music, 2004.

VEILHAN, J.C. The Rules of Musical Interpretation in the Baroque Era. Paris: Alphonse Leduc, 1979.

La Flûte à bec Baroque selon la Pratique des XVIle et XVIIle siècles. Paris: Alphonse Leduc, 1980. 


\section{Encarte de CD's}

POTTIER, L. Jacques Hotteterre: Premier Livre de Pièces pour la flûte traversière. Music for Flute vol.1. França: Naxos, 1997.

Jacques Hotteterre, Le Romain. Music for Flute vol. 2. França: Naxos, 1999. 


\section{ANEXOS}

\section{Tabela de digitação dos Battements}
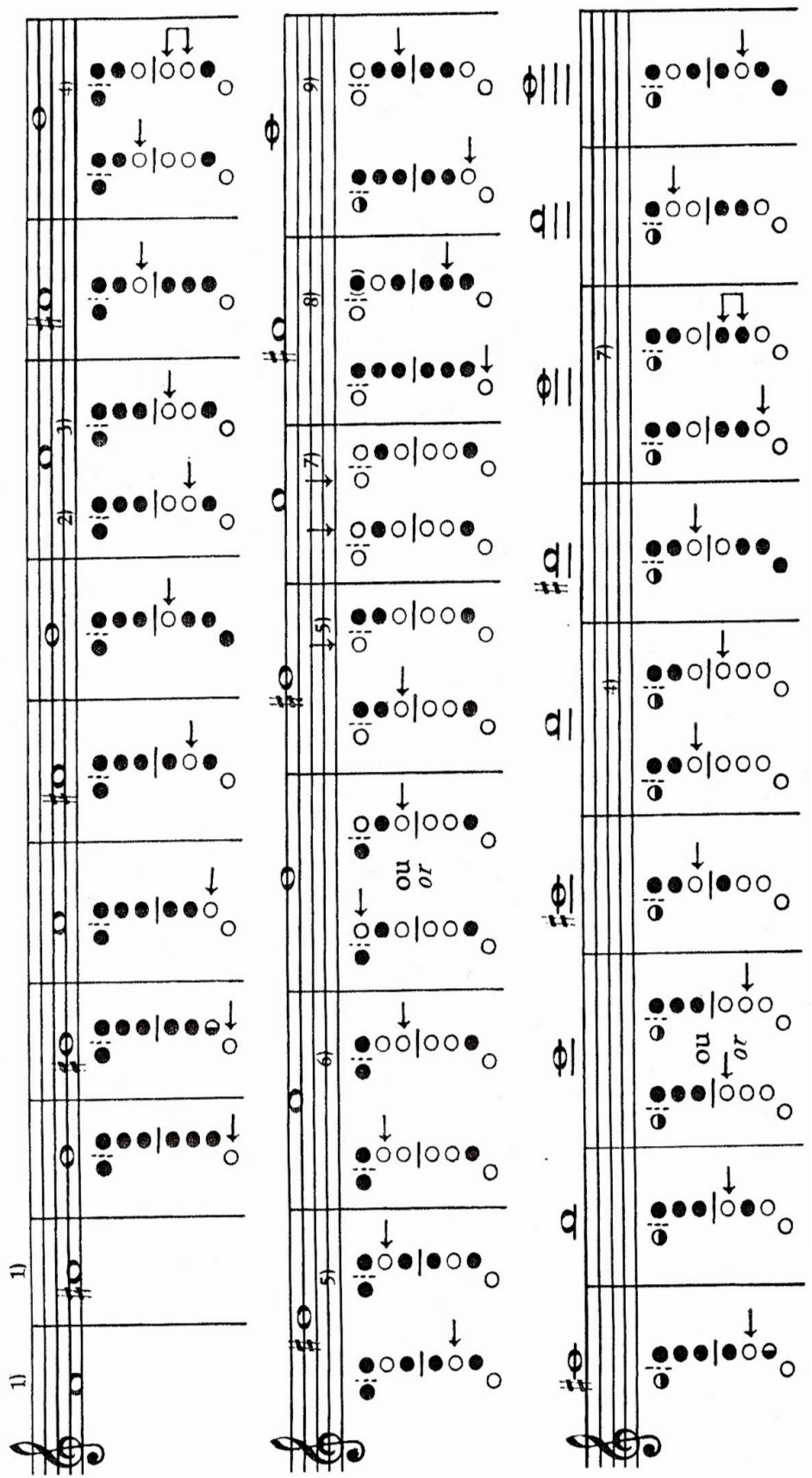

1) Não se pode fazer um battement nessas notas; 2) Em um tom natural; 3) Em um tom onde o si for bemol; 4) Quando for precedido por um port de voix sustenido; 5) Quando for precedido por um port de voix; 6) Quando for precedido por um ré sustenido; 7) Quando for precedido por um port de voix natural; 8) O battement também é realizado sobre o sexto buraco abrindo o terceiro, e às vezes também o segundo. Então é necessário tapar o sexto buraco no fim; 9) Quando o battement for precedido por um port de voix natural, ele deve ser feito sobre o quarto furo com o primeiro e segundo furos abertos. Deve-se fechá-los no fim do ornamento. 


\section{Tabela de digitação dos Flattements}

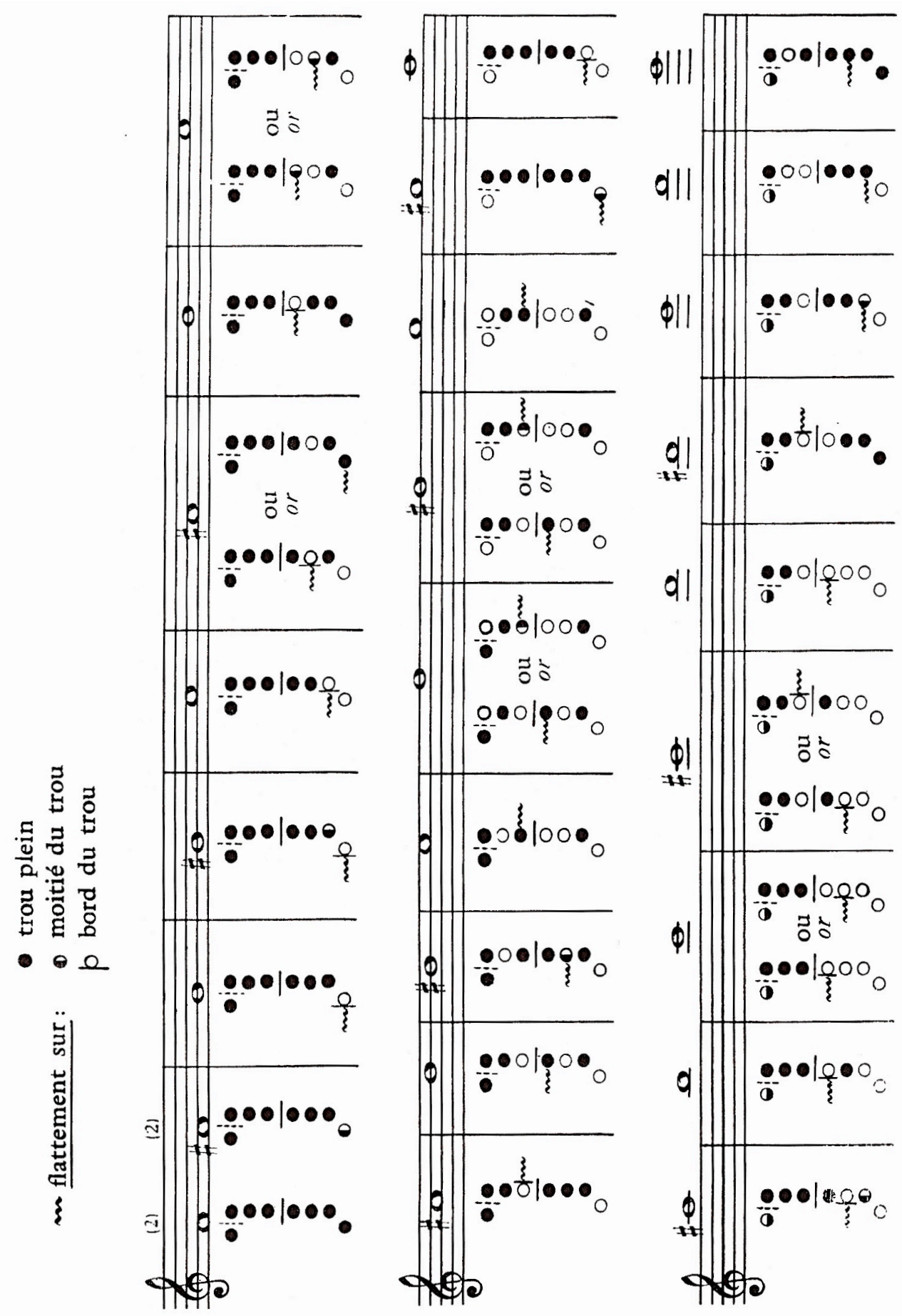

2) Só podemos fazer o flattement do fá natural inferior artificialmente. Como não possuímos nenhum dedo para fazê-lo, pois todos estão ocupados fechando os buracos, mexe-se a flauta com a mão inferior de modo que se possa imitar por este meio o flattement comum. Isso também acontece com o fá sustenido e o sol bemol. 
Tabela de digitação dos Tremblements
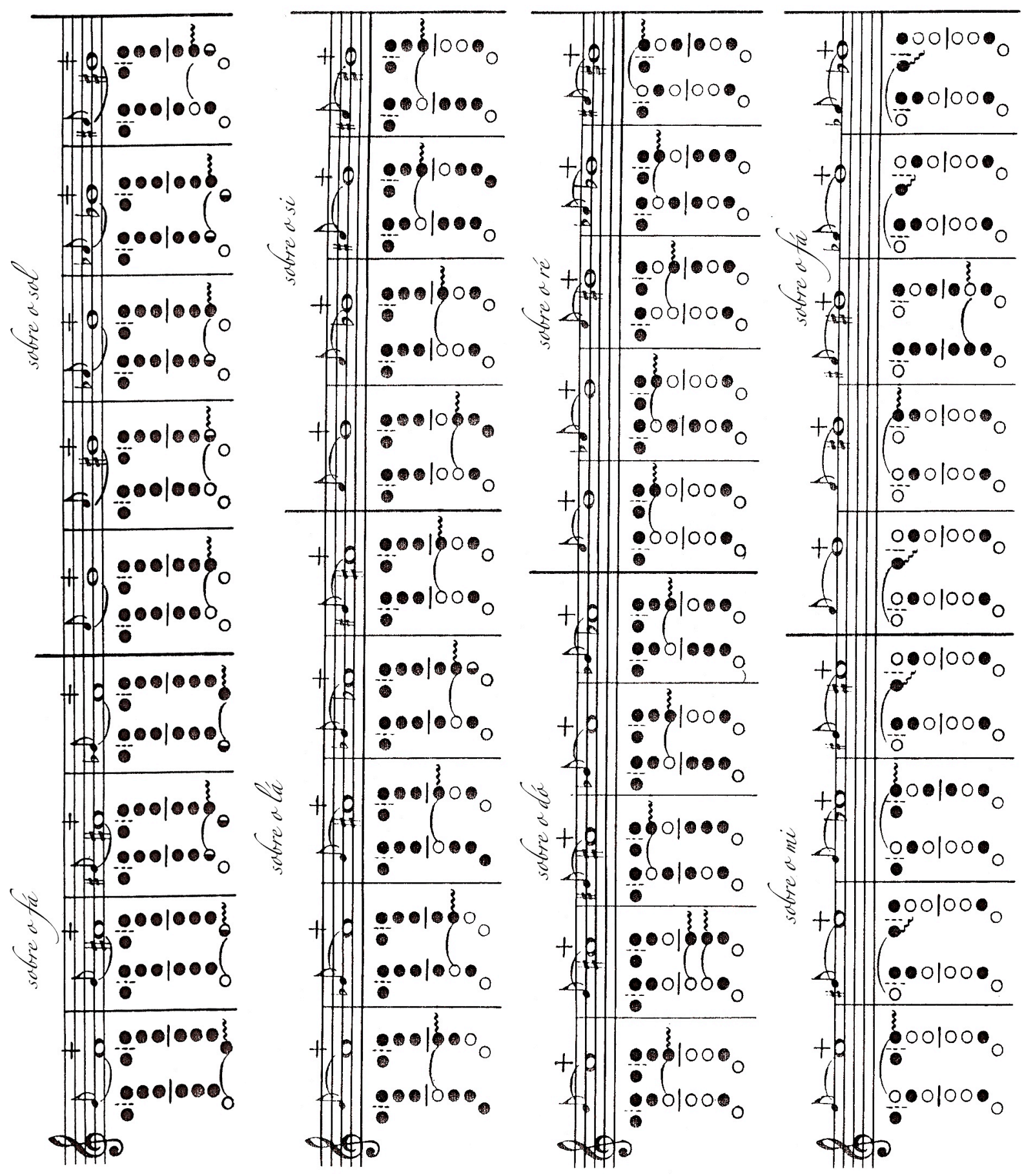

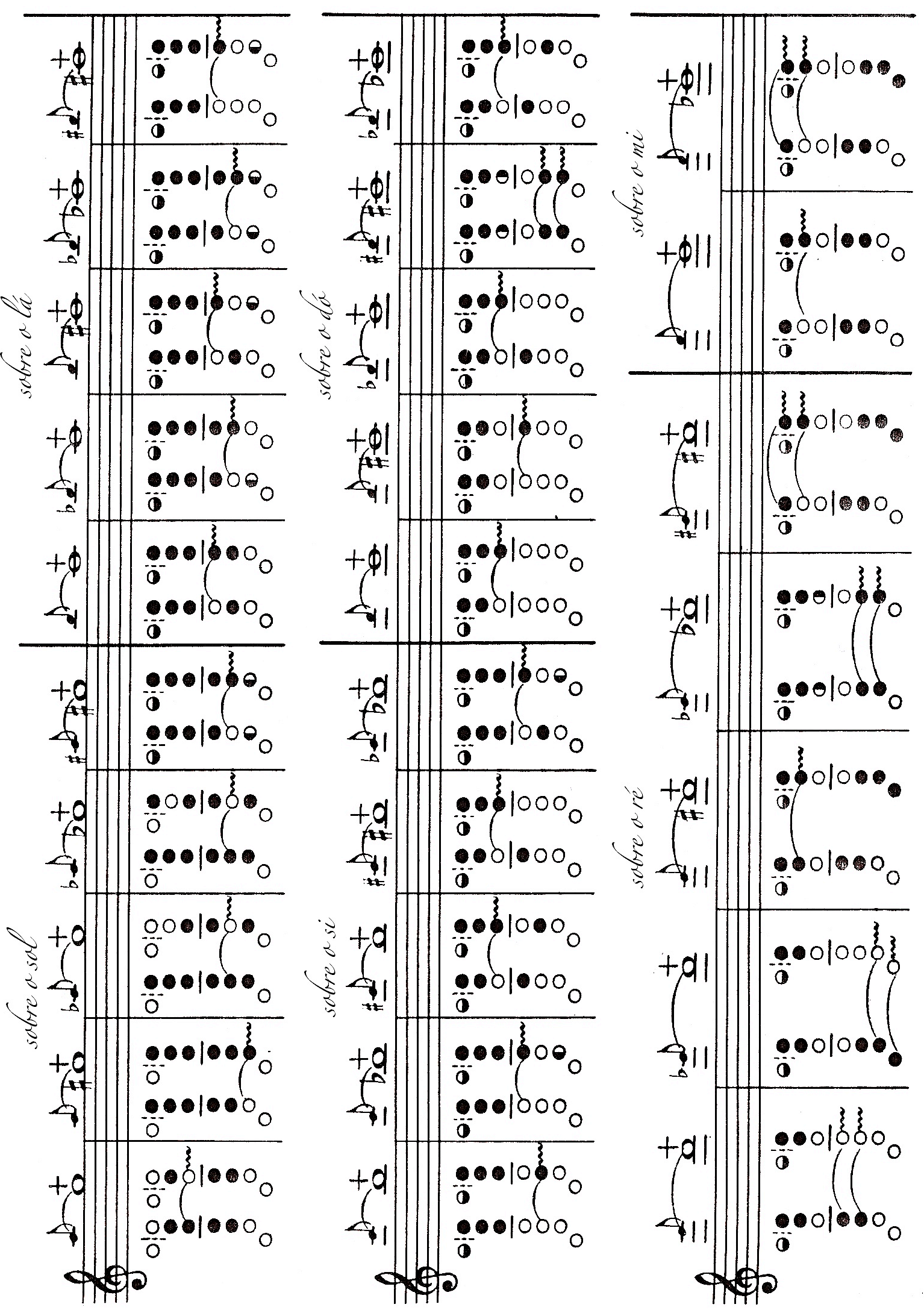


\section{ÍNDICE REMISSIVO}

Abbé François Raguenet 5

abundância 9, 10, 11

accent $8,11,27,31,33$

adagio 8, 71, 73, 177

affectueuse 71

affectueusement 71,77

affettuoso 71

agréable 9, 38, 41, 71, 72

agrément 1, 2, 27, 29, 31, 50, 51, 66

air à danser 12

air de ballets 12, 43, 177, 183, 187

alaúde 18, 29, 57

Albinoni 52

Alemanha 47-9, 55, 201

allegro 71-3

allemande 14-6, 20, 177

Amadis 173

ambiente 70, 71, 81

Amsterdam 48, 58, 61, 63

anacruse 16, 19, 23, 25, 26

animé $71,76,77$

Ann Bond 7, 29

Anthony 21, 22, 25-7, 41

Antoine Jacques Hotteterre 52

Antonio Bortoli 193

appartement 42,43

appoggiatura 32, 34

Arbeau 25

ária 17-9, 20-3, 43, 46, 47, 51, 64, 65, 68, 71, $72,75,81,93,97,159,161,163,169,173$, $175,177,183,185,187,189,191$

aria del sonno 181

Aristóteles viii, 11, 55, 56

armadura de clave 31, 81, 106, 112, 149, 161,165

arte 2, 10, 48, 54, 56, 59, 60-4, 89, 91, 201, 202

Arte de Preludiar 1-3, 20, 39, 51, 52, 56, $57,63,65,66,76,77,81,83,85,93,103$, 194, 201-03

articulação 37-9

auctoritas 55

Bacilly 35

badin 71

badiner $71,72,79$

baixo contínuo 49, 50, 55, 175

baixo obbligato 17

baixo ostinato 18

Ballard 41, 47, 48, 49, 52, 70

Barroco 1, 5, 6, 8, 14, 37, 44, 46, 54, 55, 57, 70, 81

battements 31, 32, 34, 211

Beaussant 14

Bellerophon 163

Benoit 14-8, 20-3, 26, 42-5, 47, 55, 63, 66,

$67,85,93,105,175,181$

Berlim 12, 36

Bismantova 193

Blainville 6, 7, 9, 11, 12, 89

Boécio 55

Bologna 36

Bouissou 19, 22-7, 29, 44, 65, 70, 97

bourée 13, 181
Bousset 51

branle 16, 18, 19, 25, 181

Brasil 1, 3

broderies 28

Brossard 2, 5, 6, 12, 13, 15-9, 20-5, 27, 28 , $58,59,60,61,62,67,69,70-5,78,89,202$ brunette 51, 175

Bukofzer 54, 55, 65

cadence feinte 33,34

cadência $17,26,27,33,52,53,65,91,93$, 97, 105, 151, 153, 157, 159, 195

Cadmus 163

Callot 62

canarie 17, 185, 181

Caneva 2, 63-8, 70, 71, 93, 99, 101, 129, 201, 202

Cano 55

canovaccio 64

cantatas 59, 68, 89, 97, 177, 185, 189 cantochão 68

capricho 2, 59, 60-3, 66, 89, 119, 202

caractère 2, 6, 7, 50, 68, 71, 91

Castellani 66

castrat 42

cavalariça 41, 42, 45

Cavalli 46

Cesare Ripa 60, 61, 62

chaconne 17, 18, 24, 25, 183

chalumeau 46

Chambonnière 29

chanson 17,19

chant 17, 18, 22, 24, 28, 29, 66, 67, 69, 97, 159

chapelains 43,44

Charpentier 70, 76, 77, 78, 79, 80, 203

Chédeville 44

chiaroscuro 8

chûte 32

ciência 55, 62, 80, 89, 163

coda 15

coloratura 27

commedia dell'arte 64

Compan 26

Comparaison de la musique italienne et de la musique française 5, 6

compasso 2, 16-9, 20-7, 31, 35, 36, 39, 51, $53,61,75,85,91,93,101,105,153,161$, $163,177,179,181,183,185,187,189,191$ 193, 194

Concert du rossignol 52

Concerto 8, 42, 50, 52

consonância 68,97

contraponto 55,80

cordas 68, 69, 95, 97, 99, 119, 153, 157, 161, 163

Corelli 22, 36, 66, 183

coreografia 19

cornamusa 43

corneto 43

Corrette 36, 63

corte 7, 16, 18, 27, 41-6, 48, 72, 87

cotillon 18, 19, 181

coulé 27, 32, 37 coulement 31, 32

couleur 27

coupée 34

couplets 17-9

coups de langue 38

courante 13, 19, 20, 36, 181, 183

cravo 31, 57, 191, 194

croches égales 22, 37

cromornos 43

D'Alembert 18, 24

D'Anglebert 29

dança 1, 8, 12-9, 20-7, 42, 57, 65, 71, 75, 181,191

danse forte 20

Dechaume 14

decoro 6, 129

demie cadence appuie 33

Descoteaux 45

desigualdade de notas 1, 35, 36, 38, 202 desigualdade rítmica 39, 202

dessein 61, 89, 151

dessus 2, 22, 31, 50, 51, 52, 69, 85, 159, 165

dessus de viole 31

détaché 33, 37, 66

diminuição, diminutione 27, 28, 66, 67

discurso retórico 11, 54

discurso sem palavras 9

Donington 35, 36

double 47

double cadence 31,34

doux 72

Duc d'Orléans 50

Édito de 176143

Eisel 48

elegância 8, 31, 35

Elisabeth-Geneviève Charpentier 52 en battant 21

Énergie des modes 70

engenho 2, 6, 11, 61, 62, 63, 89, 103, 202 entrée 20, 23, 181

Espanha 26

Estienne Roger 48

estilo baixo 10, 11

estilo francês 1, 8, 9, 11, 12, 66, 67, 181

estilo grande 10, 11

estilo italiano 1, 7, 8, 9, 11, 14, 64, 66, 67 estilo nobre 11

estrutura bipartida 19, 23, 25

exordium 58

família Hotteterre 41, 44, 47

fantasia 61,62

Fargis 50

Felipe II 26

Feuillet 18, 19

fièrement 72,77

figura 27, 32, 33, 34, 38, 55, 99, 201

flattements 31, 32, 212

flauta doce $2,31,45,47,51,57,85,93$, $105,129,137,139,141,146,165,201$ 
flauta traversa 2, 30, 31, 32, 39, 41, 45, $47,48,49,50,51,52,85,87,93,105,129$, $173,175,201$

Florença 2, 29, 31, 49, 50, 66

Florilegium Secundum 67

flûte à bec 2, 47, 50, 57

flûte de la chambre du roy 41,44

forlane 21, 187

Foucault 47, 48, 85

Francesco Maria Ruspoli 8, 45

Francesco Tosi 36

Francisco $/ 42$

François Couperin 7, 29, 36, 76, 191, 194

Freillon-Poncein 57, 59

Frescobaldi 35, 37

fugas $8,97,177$

Furetière 2, 58, 59, 61, 62, 64, 65, 68, 71,

72-5, 87, 89, 93, 97, 99, 159, 163

gailliarde 13

gamma 101

Ganassi 28,67

gavotte 13, 14, 16, 21, 25, 181

gay, gai 13, 16, 21-5, 33, 72-4, 76-9

Genebra 35, 41

gewiss 13

giga 14, 16, 17, 22, 23, 75, 185, 187, 189

Girolamo Dalla Casa 28

Girolamo Diruta 28

gosto [goût] 7, 8, 31, 36, 45, 52, 66, 72, 119, 194

gracieusement 72, 77

gracieux 72,73

grande bande 42

grave 15, 21-4, 73, 74, 77, 78, 79, 181, 187

gravement 73, 74, 77, 78, 79, 105

grupettos 28, 34

Guido D'Arezzo 101

Harmonia das Esferas 55

Harmonie universelle 28, 68

Harnoncourt 7, 16, 19, 24, 26, 27

haro 87

hautbois 2, 43, 47, 48, 50, 51

hautbois du roy 44

Hauteterre 45, 47

Haynes 43, 67

hemiólias 19

hexacorde 101

House 7, 14, 15, 45-9, 51-4

huissier 87

lconologia 60, 61

improvisação 8, 53, 59, 62, 63, 202

improviso 28

inégalité 35, 36, 37, 105, 179, 181, 202

ingenios 62, 63

Itália 7, 8, 45, 47, 64, 67, 193

J. B. de Boismortier 28

J'ecoûtois autrefois 46

Jacques Martin Hotteterre - Le

Romain 2, 3, 5, 8, 15, 20, 28, 29, 30-4, 37-9, 40-1, 44-9, 50-2, 53-9, 59-2, 63-9, 68-3, 76-9, 78-3, 83, 85, 87, 200, 202, 203

Jean Baptiste Hotteterre 52

Jean Hotteterre 47, 51

Jean Laurent le Cerf de la Viéville 5

Juan Huarte 62, 63

L'Art de Toucher le Clavecin 194

L'Art de Preluder 1-3, 15, 50-4, 56, 63, 66, 67, 68, 71, 81, 83, 193, 194, 202, 203

L'Esprit de L'Art Musical ou

Réflexions sur la Musique 6

La Fontegara 28 largo 73

Lasocki 8, 28, 45, 48, 52

léger 73, 77

légèrement 73,77

lentement 71, 73, 74, 77

Leopold Mozart 44

Les Goûts Réunis 7

levare 16, 17, 21, 26, 187

licence 163

Lorenzo Penna 193

Loulié 36, 37

lourd 73, 74

lourdement 74, 77

loure 22, 187

lourer, louré 37

Loys Bourgeois 35

Luís XIV 7, 8, 24, 41, 44, 46

Lully 7, 8, 51, 65, 67, 157, 159, 179, 181

luthier 44

Magnificat 68

marche 23, 181

Marpurg 97

marqué $73,74,77$

matéria 6, 11, 63, 64, 68, 157, 202

Mather 28, 32, 33, 34

Mattheson 48, 70

medida 9, 17, 18, 19, 22, 23, 25, 31, 36, 39,

44, 53, 61, 74, 75, 93, 185

melopée 97

Mémoires de Trevoux 47, 48

Mercure de France 47

Mercure Galant 47

Mersenne 28, 68

mesure 2, 9, 10, 16, 17, 18, 21-6, 28, 39, 51,

$61,67,93,187$

Méthode pour la musette 52

método 52, 56, 57, 63, 89, 91, 93, 129, 161,

$165,175,201$

México 26, 55

Michel de la Barre 28

Minkoff 2, 41, 52, 58, 61

minueto 13, 23, 24, 25, 183

modéré 9, 18, 19, 24, 25, 74, 77

modo 2, 17, 21-6, 31, 53, 55, 57, 58, 68, 69,

$70,71,77,78,79,80,81,93,95,97,101$,

$103,112,114,149,151,153,157,161,163$,

$165,175,202,203$

modo maior 17, 70, 78, 95, 157

modo menor 17, 95, 157

modulação/modulation 2, 50, 51, 80, $85,89,91,93,97,101,105,149,151,157$, 159

Molinié 9, 10, 11, 89, 129

Montéclair 33, 36

mordente 34

moteto 177,189

mouvement 2, 9, 15, 18, 19, 23-6, 50, 68

Muffat 35, 67

musette 43, 45, 46, 51, 52

música barroca francesa 1, 3, 37, 52, 105

música instrumental setecentista 1

14, 203

musica poetica 54, 55, 201

musica practica 54, 55, 56

musica theorica 54, 55

musiciens du roy 44

Musikalisches Lexicon 48

musique de la chambre 41-3, 45, 52

musique de la chapelle royale 41-3

musique de la grande écurie 41-3

Nápoles 35 nota final 17, 80, 101, 157, 163

notes inégales 36-8

oboé 2, 31, 43, 47, 50, 51, 85, 105, 129, 165

officiers de la maison du roy 44

ópera Thésée 157

ópera xerse 46

oratórios 43, 129

Orchésographie 25

ornamentação 8, 10, 27, 28, 29, 32, 34,

$55,66,67,81$

ouvertures 58, 181

page $42,43,48,50$

paixões 8, 9, 11, 12, 70, 75

Parallèle des Italiens et des Français

en ce qui regarde la musique et les opéras 5, 6

Paris 2, 10, 14, 18, 24, 29, 31-3, 35-8, 41, 44, 47-9, 50, 57, 58, 61, 63, 67, 70, 85, 87, 95

passacaille 24, 25, 183

passages, passaggio 28, 66, 67, 202

Passau 67

passepied 13, 25, 26, 185, 181

petite bande 42

petite reprise 15

petits violons du roi 42

peu animé 71, 77

Philidor 43

pièces de caractères 1, 12, 13, 15, 181

Pierre Duval 29

pincé 34

piquer, piqué 37, 181

plain-chant 44, 68

plaintes 181

plano 64-6, 93, 169, 171, 175

planus cantus 44

Poética 54-6, 80

pointer 1, 35, 37, 39, 105, 177, 179, 181, 185, 202

Poitou 23, 43, 45, 46

port de voix 27, 31, 32, 33, 34

postura 62

prélude composé 59

prélude de caprice 57, 59, 63, 89, 194, 202

prelúdio viii, 1-3, 20, 28, 35, 40, 51-4, 56-9,

$60-8,70,76,77,78,79,81,85,89,91,93$

$95,97,99,101,103,105,114,129,139,149$,

$153,157,159,163,165,167,175,177,193$,

194, 195, 202

primeira orquestra 42

princípio 2, 3, 11, 19, 29, 36, 39, 47, 51-4,

57, 63-5, 85, 89, 97, 101, 165, 175, 201

privilégio 49, 50, 85,87

propreté 31

Proserpine 163

prova 99, 159

Puliaschi 35, 37

Quantz 12-4, 24, 25, 36, 48, 49, 191

Quintiliano 58

Racot de Granval 66

Rameau 18, 21, 29, 70, 97

Ranum 37, 71, 81

recueil d'airs 46, 52

Règles de Composition 70, 203

regras 3, 31, 55, 56, 57, 62, 64, 66, 67, 80,

87, 89, 93, 97, 149, 163, 169, 173, 201, 202

reis merovíngios 43

Renascença 15, 16, 57

Renascimento 54

repertório de tópicos 55

reprise 15, 19, 20,21, 23-6, 175, 187 
retórica viii, 2, 10, 11, 54, 55, 56, 89, 129,

Revolução Francesa 43

ricercata 61

Richelet 71-4

rigaudon 13, 25, 26, 181, 191

ritournelles 58

Rodde 43

Roger North 35

Roland 163, 173

Roma 35, 45

rondeau 17, 18, 21, 23, 24

rondement 74,77

Roubaud 71, 79

Rousseau 12, 21, 71-5, 79, 85

Rowland-Jones 8, 9

sacabuxa 43

Saint-Lambert 36

Saint-Simon 24

saltarello 75

sarabanda 13, 14, 16, 23, 26, 27, 183

sautillant 22, 75

sautillé 75, 77

Saverio Franchi 45

Scarlatti 35

síncopa 16

sinfonia 97, 165

solmização 101

sommeils 181

Sonata 8, 36, 50, 51, 52, 58, 59, 66, 68, 89 97, 177, 181, 185, 189

sonates en trio 50

spiritoso 71

stilo choraico 12-4

stilo symphoniaco 12, 14, 165

style beau 5, 9, 10, 11

style grand 5, 9, 10

suíte 14-7, 20,23, 25, 50, 58, 59, 66, 89, 181

symphonie 15, 16, 20, 58, 68

table des agréments 29

tactus 193

tambourin 26, 191

Tarling 58

técnica 1, 54, 55, 56, 57, 129, 202

tempo alla breve 179

tempo di cappella 179

tempo di gavotta 179

tendrement $71,75,76,77$

terça maior 31, 69, 70, 77, 78, 79, 91, 93, $97,149,151,161,163,165$

terça menor 24, 31, 69, 70, 77, 78, 79, 91, $93,149,161,163,165,175$

Thoinan 44, 45

tonalidades 53, 68, 70, 80, 97, 101, 203

Torelio 52

tour de chant 6, 34

tour de gousier 34

tragédia lírica 181

trait 2, 64-8, 70, 71, 91, 93, 119, 141, 146,

194, 201, 202

Traité de L'Harmonie 70

transposição/transposition 2, 31, 50,

51, 57, 85, 167, 169

tremblements 31, 33, 34, 213

tremolos 28

Trevoux 47, 48, 72, 73

tríade 69,81

trinados 33

trio harmônico 69

trombas marinas 43

turn 34
Valentine 51

variações 10, 11, 17, 25, 37, 65, 66, 93, 97,

99, 101, 149

variedade $8,10,11,17,27,61,68,89,159$,

201, 202

vaudeville 17, 65

Vaugelas 72

Veilhan 18, 25, 32

Veneza 20

Versailles 42

vício 61

vif 26, 74, 75, 77, 93

vingt-quatre violons du roi 42

viola da gamba 31

violino 8, 31, 43, 44, 50, 52, 169

violon de la chambre du roy 44

violons du cabinet 42, 43

virtude 61

virtuosismo 8

vivace $71,73,75$

vivement 75, 76, 77

Walsh e Hare 48

Walther 48 